UNIVERSIDADE DE SÃO PAULO

ESCOLA DE ARTES CIÊNCIAS E HUMANIDADES

PROGRAMA DE PÓS GRADUAÇÃO EM TÊXTIL E MODA

LAIS KOHAN

Sustentabilidade em calçados: panorama brasileiro, materiais e contribuição de material para solado

São Paulo

2020 


\title{
LAIS KOHAN
}

\section{Sustentabilidade em calçados: panorama brasileiro, materiais e contribuição de material para solado}

\author{
Versão Corrigida
}

Dissertação apresentada à Escola de Artes, Ciências e Humanidades da Universidade de São Paulo para a obtenção do título de Mestre em Ciências do Programa de Pós-Graduação em Têxtil e Moda.

Versão corrigida contendo as alterações solicitadas pela comissão julgadora em 20 de novembro de 2020. A versão original encontra-se em acervo reservado na Biblioteca da EACH/USP e na Biblioteca Digital de Teses e Dissertação da USP (BDTD), de acordo com a resolução CoPGr 6018, de 13 de outubro de 2011.

Área de Concentração:

Materiais e Processos Têxteis.

Orientadora:

Profa. Dra. Júlia Baruque Ramos

São Paulo 
Autorizo a reprodução e divulgação total ou parcial deste trabalho, por qualquer meio convencional ou eletrônico, para fins de estudo e pesquisa, desde que citada a fonte.

CATALOGAÇÃO-NA-PUBLICAÇÃO

(Universidade de São Paulo. Escola de Artes, Ciências e Humanidades. Biblioteca) CRB 8- 4936

\section{Kohan, Lais}

Sustentabilidade em calçados: panorama brasileiro, materiais e contribuição de material para solado / Lais Kohan ; orientadora, Júlia Baruque Ramos. - 2021 $205 \mathrm{f}$. : il

Dissertação (Mestrado em Ciências) - Programa de PósGraduação em Têxtil e Moda, Escola de Artes, Ciências e Humanidades, Universidade de São Paulo, em 2020

Versão corrigida

1. Calçados - Fabricação ; Produção - Brasil. 2. Resíduos sólidos. 3. Materiais compósitos. 4. Logística reversa. 5. Sustentabilidade. I. Baruque-Ramos, Júlia, orient. II. Título.

CDD 22.ed. -.685 .301981$ 
Nome: KOHAN, Lais

Título: Sustentabilidade em calçados: panorama brasileiro, materiais e contribuição de material para solado

Dissertação apresentada à escola de Artes, Ciências

e Humanidades da Universidade de São Paulo como requisito para a obtenção do grau de Mestre em Ciências do Programa de pós-Graduação em Têxtil e Moda.

Área de Concentração: Materiais e Processos Têxteis.

Orientadora: Profa. Dra. Júlia Baruque Ramos

Aprovado em: 20 / 11/ 2020

\section{Banca Examinadora}

Prof. Dr. Holmer Savastano Jr.

Julgamento: Aprovada

Prof. Dra. Cristiane Martins Reis

Julgamento: Aprovada

Prof. Dr. Paulo E. Fonseca de Campos

Julgamento: Aprovada
Instituição: FZEA/USP

Assinatura:

Instituição: UNIFESP

Assinatura:

Instituição: FAU/USP

Assinatura: 


\section{Agradecimentos}

Agradeço a minha mãe, Marcia Naomi Kuniochi e a grande amiga Larisse Kupski, que me encorajaram no início para retornar à Universidade.

Ao meu companheiro, Dário Teodoro que sempre apoiou no que foi preciso com muita paciência, amor e carinho.

À minha família, que também me apoia, por parte de pai, Mauro Kohan, André e Lucia, minhas tias Sarah Rosely, Laércio Marzagão e David; convivo bastante com todos vocês, que são muito estudiosos e inteligentes e sempre pude sempre me espelhar. A vovó Bertha, que infelizmente não está mais aqui, mas lembro da sua doçura e da convivência durante grande parte da minha vida. Por parte de mãe, Marcus, o tio Kito e a tia Akemi, meus primos, além da Ba, a Bathian que continua firme e sempre dá seus conselhos.

À professora Julia Baruque Ramos, que desde à Graduação foi minha mentora no TCC, em que já havia me apresentado à vida acadêmica, inclusive com direto à viagem para congresso no Peru (2009). E, agora, no retorno à EACH, no mestrado, incentivou e instruiu todos os passos para o desenvolvimento acadêmico (disciplinas, congressos, artigos, network, entre outros).

Aos meus colegas, que entraram junto comigo e caminhamos lado a lado, Luciano Pinheiro e Larissa Duarte, obrigada pela parceria, paciência e diversões. Mariana Laktim mostrou o "caminho" do mestrado e se tornou uma grande amiga; Ivete Cattani me deu conselhos e plantou a sementinha do doutorado. Outros colegas que passaram por lá, no grupo da "Criaturas da Júlia", como: Letícia Legallati, Palloma Fernandes (parceira de tema e artigos), Lais Pennas, Bárbara Contin, Mylena Uhlig e Raíza Soares.

À Bárbara Leonardi, junto com o Sr. Lorival Flor, possibilitaram a realização do teste FTIR, na Golden Química; Lia Coelho que fez o teste MEV, no Centro Brasileiro de Pesquisas Físicas (CBPF). Marcia Cristina Silva, que com muito conhecimento, contribuiu muito para o desenvolvimento estatístico do estudo.

Às empresas Karina, Braskem e Atina, que doaram insumos fundamentais para a realização dessa pesquisa.

Aos professores, Dr. Holmer Savastano Jr., que por muitas vezes participamos dos congressos internacionais em Pirassununga e que, em breve iniciarei como sua orientanda. Dra. Cristiane Reis Martins, que a partir de um encontro em congresso do calçado, surgiu uma oportunidade de conhecer seu trabalho, fazer disciplina e desenvolver um experimento. Além do colega Alexandre, que com paciência e conhecimento, sempre me ajudou no laboratório.

Em Portugal, aos professos Dr. Raul Fangueiro e Dr. Pedro Souto possibilitaram a permanência na Universidade do Minho (Engenharia Têxtil). A aluna Ana Patrícia Veiga e o Eng. Joaquim Jorge propiciaram ensinamentos no laboratório têxtil, que foi muito solicito em Portugal nos acompanhou em diversas visitas externas nos arredores de Guimarães para aumentar nosso conhecimento, durante a estada em 2019.

À CAPES (Coordenação de Aperfeiçoamento de Pessoal e Nível Superior) pelo auxílio financeiro concedido, o qual viabilizou a realização deste trabalho. 


\section{RESUMO}

KOHAN, Lais. Sustentabilidade em calçados: panorama brasileiro, materiais e contribuição de material para solado. 2020205 f. Dissertação (Mestrado em Ciências) - Escola de Artes, Ciências e Humanidades, Universidade de São Paulo. São Paulo, 2021. Versão Corrigida.

O Brasil é o quarto maior produtor de calçados do mundo, exporta parte da produção, porém o valor mais expressivo em volume de vendas é no mercado nacional. A concorrência internacional, sobretudo com a China, fez com que o país buscasse a redução de custo em mão de obra. A gestão de resíduos sólidos no Brasil, foi regulamentada, porém poucas ações estão sendo feitas na prática. Mesmo assim, há casos de empresas calçadistas brasileiras adotando medidas na gestão de resíduos, no viés proativo, por meio da minimização de resíduos, a partir do design (impressão 3D) e da substituição de materiais (insumos químicos atóxicos, tingimento natural, biopolímero); no viés reativo, por reuso (resíduos do processo), reciclagem (componentes poliméricos), geração de energia (coprocessamento) e descarte (tratamento de efluentes). Esta pesquisa teve como objetivo estudar as ações sustentáveis das empresas brasileiras de componentes de calçados; verificar o que compõe o selo nacional "Origem Sustentável" e sua contribuição para o setor; e, também, realizar uma formulação de solado de PVC com inserção de serragem de bambu e avaliar suas propriedades mecânicas, FTIR, MEV, DSC e TGA. Os resultados das entrevistas com as empresas mostraram que em algumas delas são empregadas matérias primas recicladas; e que os fabricantes entrevistados de laminado e solado de PVC têm baixa emissão de resíduos e efluentes; um outro, produz componente de calçado com $50 \%$ de resíduos de tecidos e laminados vindos dos clientes. Além disso, o selo Origem Sustentável propiciou economia em insumos e no descarte, e dá suporte às empresas a exportarem e controlarem as substâncias restritas. O desenvolvimento do compósito obteve boa dispersão da serragem de bambu, porém houve a diminuição do desempenho das propriedades mecânicas em todas as amostras, em relação ao PVC puro. Por fim, corroborando com a literatura, constatou-se que há poucas soluções concretas no Brasil, referentes à circularidade dos produtos. Com base nestas considerações, sugere-se pesquisas futuras em logística reversa, biopolímeros, reciclabilidade de calçados e soluções em design.

Palavras-chaves: Calçados brasileiros. Resíduos sólidos. Materiais compósitos. Logística reversa. Sustentabilidade. 


\begin{abstract}
KOHAN, Lais. Footwear sustainability: Brazilian panorama, materials and contribution of sole material. 2020205 f. Dissertation (Master of Science) - School of Arts, Sciences and Humanities, University of São Paulo. São Paulo, 2021. Corrected version.

Brazil is the fourth largest producer of shoes in the world, exports part of the production, however the most expressive value in sales volume is in the national market. International competition market, especially with China, has made the country seek to reduce labor costs. The management of solid waste in Brazil has been regulated, but few actions are taken in practice. Even so, there are cases of Brazilian footwear companies adopting actions in the management of residues, in a proactive bias, through the minimization of residues, from the design (3D printing) and the substitution of materials (non-toxic chemical inputs, natural dyeing, biopolymer); in the reactive bias, through reuse (waste from the process), recycling (polymeric components), energy generation (coprocessing) and disposal (effluent treatment). This research aimed to study the sustainable actions of Brazilian footwear companies of components; verify the national seal "Sustainable Origin" composition and its contribution to the sector; and, also, carry out a PVC sole formulation with bamboo sawdust and evaluate its mechanical, FTIR, MEV, DSC and TGA properties. The results of the company's interviews showed that some of them have used recycled raw materials; manufacturers interviewed from PVC laminate and sole generate low waste and effluent emissions; another, a footwear component company applied $50 \%$ of fabric and laminate wastes from customers. In addition, the Sustainable Origin seal provided savings in inputs and disposal and supports companies to export and control restricted substances. The development of the composite obtained good dispersion of the bamboo sawdust, but there was a performance decrease of mechanical properties in all samples, in relation to pure PVC. Finally, corroborating with the literature, it was found that there are few concrete solutions in Brazil, regarding the circularity of products. Based on these considerations, future research on reverse logistics, biopolymers, footwear recyclability and design solutions are suggested.
\end{abstract}

Keywords: Brazilian footwear. Waste management. Composite. Reverse logistics. Sustainability. 


\section{LISTA DE FIGURAS}

Figura 1 - Balança comercial de calçados no Brasil.

Figura 2 - Comparação entre a importação brasileira de produtos chineses, calçados versus componentes de calçados (1997-2019) (Em milhões US\$)

Figura 3 - Concentração do emprego e das empresas calçadistas brasileiras, de acordo com o tamanho das empresas em número de trabalhadores (faixa de emprego)

Figura 4 - Porcentagem e quantidade (milhões de pares) calçados produzidos por estado e os principais polos de cada estado no Brasil

Figura 5 - Concentração dos principais polos calçadistas nas unidades da federação do Brasil

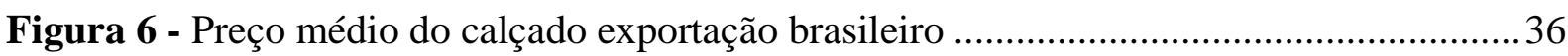

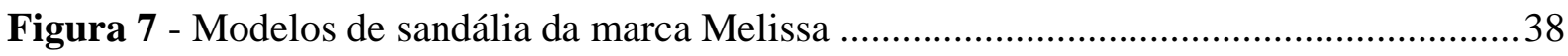

Figura 8 -Ligamentos fundamentais de tecidos - a: tecido em tear, b: tecido em malharia, c: não tecido 38

Figura 9 - Exportações brasileiras por tipo de couro bovino (2018, \% área- $\mathrm{m}^{2}$ ) .39

Figura 10 - Tipo de matéria prima dominante na exportação de calçados brasileiros (entre 20032011-2019)

Figura 11 - Composição principal de um calçado feminino 42

Figura 12 - Descrição de todos os componentes de um calçado de salto feminino 42

Figura 13 - Calçado com gáspea decorada (gravação animal e enfeite de metal) em modelo feminino mule 43

Figura 14 - Recortes de um cabedal unidos por costura em couro e com diferentes cores.....44

Figura 15 - Partes de uma gáspea de um tênis em tecido e couro

Figura 16 - Tênis esportivo da marca Adidas ${ }^{\circledR}$ em cabedal com tecido acolchoado (mesh) e forrado

Figura 17 - Cabedal Flyknit modelo React Phantom Run da marca Nike sem forro 46

Figura 18 - Gáspea em malha 4D para tênis esportivo em múltiplos desenhos e cores 46

Figura 19 - Localização da aplicação do contraforte no calçado 48

Figura 20 - Parte inferior do calçado (palmilha, entressola e solado) e outros componentes .50

Figura 21 - Exemplos de palmilhas moldada e cortada (plana)

Figura 22 -Formatos de entressolas em tênis esportivo - (a) borracha em formato de caixa de ovo, (b) impressão 3D 
Figura 23 - Alma de ferro.

Figura 24 - Partes que compõe a pele bovina ..............................................................5

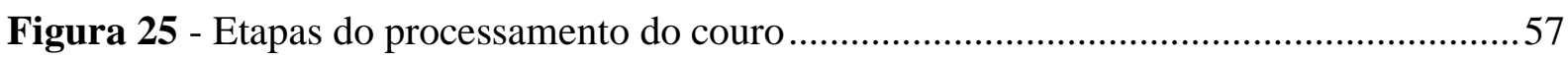

Figura 26 - Exemplo de calçado em couro bovino - A - Bota camurça (Sidewalk), B - Sandália napa semi brilho (Wishin), C - Sapato social atanado (Sergio's) .60

Figura 27 - Exemplos das matérias primas das fibras têxteis. 61

Figura 28 - Não tecidos utilizados em calçados, (a) spunlace, (b) agulhado .62

Figura 29 - Tecidos planos em calçados - (a) tear (b) calçado em cabedal de denim 63

Figura 30 - Passamanaria - (a) tear agulha 10/30, (b) sandália com solado Anabela recoberto em trançado de sisal, (c) cadarço $6 \mathrm{~mm} 100 \%$ poliéster .64

Figura 31 - Máquina malharia de urdume Raschel (7 barras) - modelo Mayer RD72-12EN 65

Figura 32 - Malharia circular: (a) tear listrador (b) forro de cacharrel (calçados Beira Rio)..66

Figura 33 - Tecnologias mais recentes em malharia 4D (dimensões) - (a) tecido em Fly-knit (com estrutura de reforço ligamento ribana), (b) Tecido feitos na máquina double needle bar Raschel - 4D - RDPJ 6/2 EL .66

Figura 34 - Malharia circular: (a) Máquina Karl Mayer \& Cia jacquard duplo (OVJA 1.1 EETT) e (b) Santoni (X Machine Sock/shoe (C) 67

Figura 35 - Laminado de PU - variedades de texturas e cores 69

Figura 36 - Laminados sintéticos: (a) PVC em diversas gravações, (b) microfibra de PU, (c) TPU aplicado no cabedal de tênis.

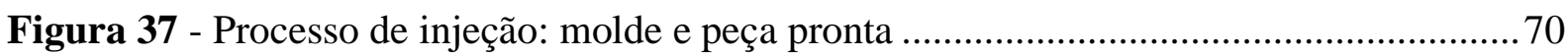

Figura 38 - Divisão da distribuição plantar (15 áreas)......................................................73

Figura 39 - Distribuição do impacto ambiental dos principais componentes de calçado .......75

Figura 40 - Estrutura da gestão de resíduos da indústria calçadista ......................................77

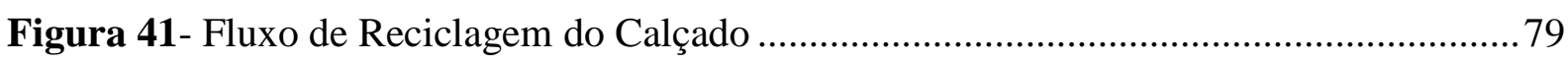

Figura 42 - Feira Inspiramais - (a) Materiais expostos - jan2019, (b) Palmilha de espuma reciclada (Ciclomade) - jun 2019, (c) - Tecidos naturais - jun 2019.

Figura 43 - Metodologia de pesquisa: pesquisa exploratória e pesquisa laboratorial, fases e objetivos de cada etapa. 86

Figura 44 - Fluxograma das etapas desenvolvidas . 89

Figura 45 - Etapas de desenvolvimento do compósito. 91

Figura 46 - Amostra de serragem de bambu sem tratamento .92

Figura 47 - Composto de PVC flexível da empresa Karina .92 
Figura 48 - Produtos químicos utilizados na segunda fase do experimento. (a) Silano Z60-11 da marca Dow-Corning ${ }^{\circledR}$ (b) Etanol da marca Synth® (c) Ácido Acético da marca Synth®.93

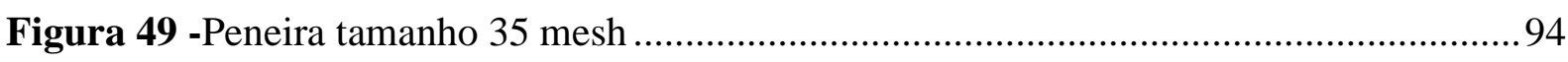

Figura 50 - Estufa termo circuladora Marconi (MA033, Brasil). .95

Figura 51 - Tratamento da serragem com $\mathrm{NaOH}$ (a) aquecimento: utilizando agitador magnético, misturador e termômetro, (b) lavagem com água para neutralização das fibras ...96 Figura 52 - Ilustra a etapa de gotejamento do silano, através do uso de um funil de adição e um misturador (5rpm).

Figura 53 - Equipamentos utilizados no processamento da mistura das fibras e o composto de PVC - (a) calandra MH-150-C-D, (b) prensa automática MH-P-8 MT-PR e (c) prensa hidráulica Tecnalise . .98

Figura 54 - Pesagem e separação dos insumos do compósito (fibras e composto de PVC) - (a) pesagem serragem, (b) separação da serragem (c) separação composto de PVC .99 Figura 55 - Placas de compósitos de PVC com serragem de bambu: (a) todas as amostras de compósitos desenvolvidos com serragem pura, tratada com silano e mercerizada, em quantidades em 1,5\%, 3,0\% e 6,0\%; (b) comparação visual entre a matriz pura (sem serragem, amostra mais à esquerda) e os compósitos desenvolvidos com serragem pura (sem tratamento), apresentados nas a quantidades de $1,5 \%, 3,0 \%$ e 6,0\%, respectivamente. 100

Figura 56 - Prensa hidráulica para corte de corpos de prova (a) prensa, amostra e faca de corte, (b) corpos de provas em formato de "gravatas" (22 $\mathrm{mm}$ de corpo, $6 \mathrm{~mm}$ de largura e 3,5 $\mathrm{mm}$ de espessura). 101

Figura 57 - Desenho esquemático do FTIR, de acordo com a frequência de cada grupo funcional 102

Figura 58 - Equipamento para análises térmicas (Hitachi STA7200) 103

Figura 59 - Dinamômetro Instron - modelo 5569 ........................................................ 105

Figura 60 - Curva esquemática da tensão-deformação de materiais 106

Figura 61 - Visualização de polímero polipropileno após fratura para realização do teste MEV - (a) fratura normal, (b) fratura criogênica 107

Figura 62 - Categoria das empresas participantes do Inspiramais (edição de janeiro, 2020) no segmento de calçados

Figura 63 - Caracterização das empresas participantes do Inspiramais (a) Localização por estado brasileiro (b) Porte das empresas. 112 
Figura 64 - Ranking de quantidade de empresas de componentes da Feira Inspiramais (edição janeiro de 2020)

Figura 65 - Empresas do Inspiramais (edição janeiro de 2020) com ações sustentáveis (a) Empresas com ações sustentáveis (\%), dentre o conjunto de participantes (b) Classificação e frequência por tipo de ações sustentáveis feitas nas empresas

Figura 66 - Local de destaque no site, onde é inserida as informações sobre as ações sustentáveis das empresas participantes do Inspiramais (edição janeiro de 2020) 114

Figura 67 - Palmilha de montagem reciclada (em placa e aplicada) empresa Ambiente Verde

Figura 68 - Desenvolvimento de gáspea sob medida para cliente em circular jacquard ....... 118

Figura 69 - Fórmula estrutural do PVC 134

Figura 70 - Compósitos de polímero e fibra vegetal aplicados em produtos no mercado calçadista - (a) Chinelo em NR e bagaço de cana, (b) Amostras composto injetado fibra-PVC da empresa PVC Sul

Figura 71 - Espectro do FTIR da serragem in natura de bambu (Dendrocalamus giganteus) empregada no presente estudo.

Figura 72 - Espectros FTIR comparados: serragem de bambu gigante (vermelho), sisal (verde), curauá (lilás), juta (azul), banana prata fibra externa do pseudocaule (rosa) e banana prata fibra interna do pseudocaule (azul). 140

Figura 73 - Resultado do ensaio de DSC e TGA, com serragem de bambu (Dendrocalamus giganteus) em Hitachi STA7200 - amostra 6,71mg, temperatura entre 0-600 ${ }^{\circ}$, em taxa de aquecimento de $10^{\circ} \mathrm{C} / \mathrm{min}$

Figura 74 - Imagens MEV do compósito PVC/bambu - 1 (1,5\% de serragem de bambu pura, sem tratamento - 200x e 1000x), M1 (1,5\% de serragem de bambu merceirizada - 170x e 850x) e S1 (1,5\% de serragem de bambu com tratamento em silano- 180x e 750x). 145

Figura 75 - Resultado da Caracterização mecânica, nas amostras de PVC puro e compósitos de PVC com serragem de bambu puro, com tratamento de $\mathrm{NaOH}$ e tratamento de silano em concentrações $(1,5 \% ; 3,0 \%$ e 6,0\%) (a) Resistência à Tração na Carga Máxima (MPa), (b) Resultado no Alongamento na Quebra (\%), (c) Carga Máxima (N) e (d) Módulo de Young $(\mathrm{MPa})$ 146

Figura 76 - Efeito das médias de velocidade de queima após ANOVA para diferentes materiais: (a) Gráfico de efeitos; (b) Carga máxima de ruptura com 95\% de intervalo de confiança .... 149 
Figura 77 - Resultados da análise dos resíduos após ANOVA carga máxima de ruptura $\mathrm{x}$ materiais: (a) Histograma dos resíduos; (b) Papel da probabilidade para os resíduos; (c) Resíduos x Valores ajustados; (d) Resíduos x Ordem de coleta......................................... 150

Figura 78 -Análise de Variância para carga máxima de ruptura $X$ tipos de materiais ......... 151 


\section{LISTA DE QUADROS}

Quadro 1- Principais marcas mundiais que produzem calçados na Indonésia.......................26

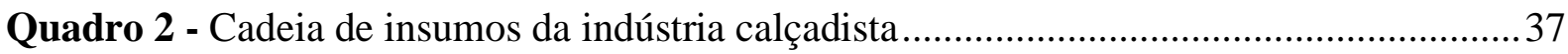

Quadro 3 - Processo Industrial do Couro (versão detalhada) ...................................................58

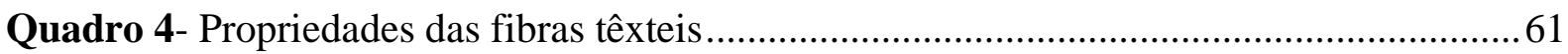

Quadro 5 - Principais polímeros utilizados em solados de calçados.......................................70

Quadro 6 - Informação da coleta de dados das entrevistas (data, segmento, porte, tipo e local

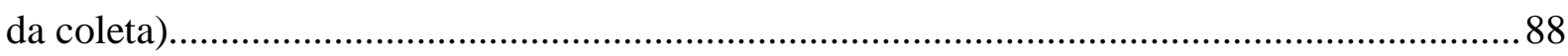

Quadro 7 - Dimensão da Gestão da Sustentabilidade do selo Origem Sustentável ............... 121

Quadro 8 - Lista de substâncias restritas aplicadas nos componentes de calçados ............... 124

Quadro 9 - Benefícios obtidos com a obtenção do selo Origem Sustentáveis, por fabricantes do setor calçadista brasileiro.

Quadro 10 - Resultados das entrevistas sobre a implantação do selo Origem Sustentável .. 128

Quadro 11 - Ações realizadas sobre a Gestão de Resíduos das empresas entrevistas ...........128

Quadro 12 - Compósitos em polímeros para aplicação em solados (ordem crescente) ........ 137 


\section{LISTA DE TABELAS}

Tabela 1 - Principais países produtores de calçados (milhões de pares) …............................24

Tabela 2 - Principais países exportadores de calçados (milhões de pares).............................24

Tabela 3 - Unidade de preço de calçado (em US\$/par) exportado dos principais países do

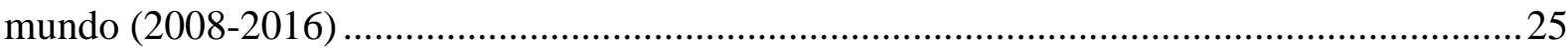

Tabela 4 - Média da cotação do dólar americano para venda Brasil (2014-2018).

Tabela 5 -Emprego na indústria calçadista brasileira por Unidade da Federação (em mil postos de trabalho)

Tabela 6 - Quantidade de estabelecimentos de fabricação de calçados por Unidades da Federação.

Tabela 7 - Preço médio do calçado brasileiro exportado (período entre os anos 2016-2018).36

Tabela 8 - Produção de calçados no Brasil por material predominante em pares (\%) 37

Tabela 9 - Evolução dos materiais do cabedal nos calçados brasileiros (2016-2018)

Tabela 10 - Evolução dos materiais do solado nos calçados brasileiros (2016-2018)

Tabela 11 - Evolução dos materiais do forro nos calçados brasileiros (2016-2018)

Tabela 12 - Impacto ambiental dos principais tipos de calçado (couro, sintético e têxteis) por categoria. .76

Tabela 13 - Classificação do Porte das Empresas Brasileiras (IBGE) .88

Tabela 14 - Peso (g) das fibras utilizadas na formulação de PVC, em placa de 150g .99

Tabela 15 - Formulação base para solado em PVC (Braskem) 133

Tabela 16 - Bandas de infravermelho determinadas para material fibroso de bambu (Dendrocalamus giganteus), banana fibra interna (Musa spp - cultivar prata), banana fibra externa (Musa spp - cultivar prata). e curauá (Ananas erectifolium), juta (Corchorus capsularis) e sisal (Agave sisalana)

Tabela 17 - Principais bandas de infravermelho médio encontradas em materiais vegetais. 142 Tabela 18 - Estimativa de concentração (\%) de água, celulose total e lignina, de acordo com as curvas TGA e DTG na amostra analisada de bambu (Dendrocalamus giganteus) e da referência da literatura para a mesma espécie de bambu. 144

Tabela 19 - ANOVA diferentes materiais e em diferentes níveis para carga máxima de ruptura 


\section{LISTA DE EQUAÇÕES}

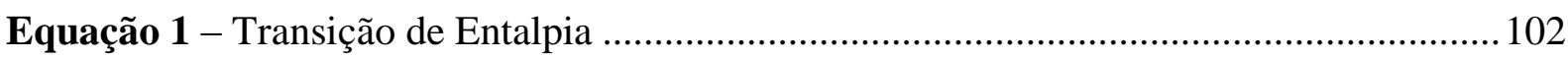

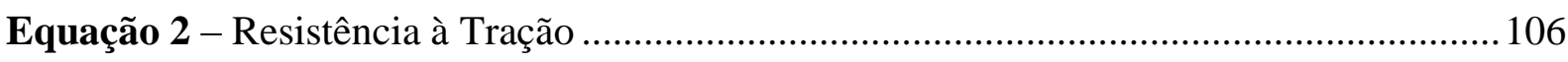

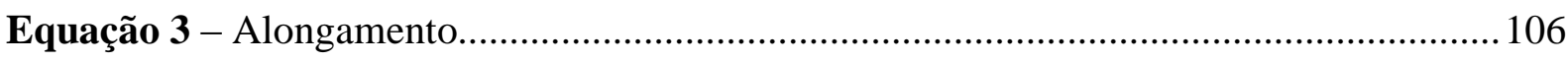

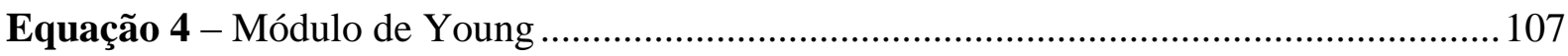

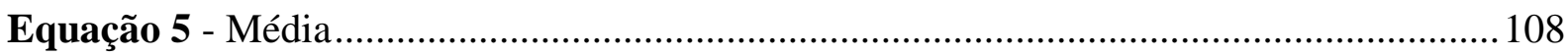

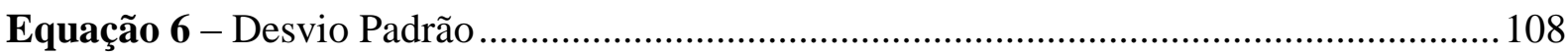

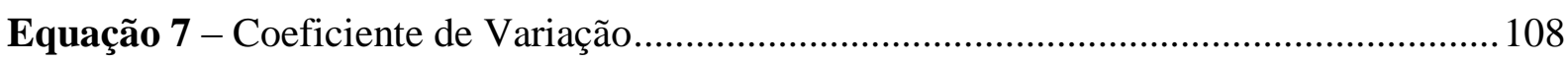

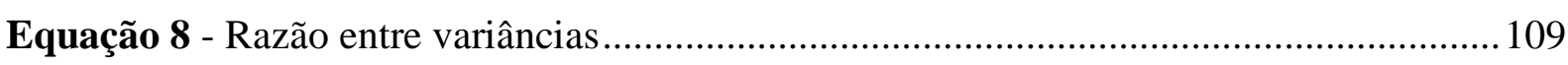




\section{LISTA DE ABREVIATURAS E SIGLAS}

Abicalçados - Associação Brasileira das Indústrias de Calçados

ANOVA - "Analysis of Variance" - Análise de variância

Assintecal - Associação Brasileira de Empresas de Componentes para Couro, Calçados

e Artefatos

ASTM - "American Society for Testing and Materials" - Sociedade Americana para Materiais e Testes

BBP - "benzyl butyl phthalate" - ftalato de benzila e butila

CICB - Centro das Indústrias de Curtumes do Brasil

CO - “Cotton" (algodão)

DBP - "dibutyl phthalate" - ftalato de dibutila

DEHP - "di (2-ethylhexyl)" - ftalato di- (2-etilhexil)

DIDP - "di-isodecylphthalate" - ftalato di-iso-decil

DINP - "di-isononyl phthalate" - ftalato di-isononil

DNOP - "di-n-octyl phthalate" - ftalato di-n-octil

DOP - "dioctyl phthalate "- ftalato dioctil

DOTP - "dioctyl terephthalate" - tereftalato de dioctilo

DPHP - "dipropylheptyl phthalate" - ftalato di-propil-heptil

DSC - "Differential Scanning Calorimetry" - Análise Térmica Diferencial

DTG - "Derivative Thermogravimetry" - Termogravimetria derivada

EVA - "ethylene vinyl acetate" - acetato de vinilo de etileno

FTIR - "Fourier Transform Infrared Spectrocopy" - Espectroscopia no infravermelho por transformada de Fourier

IBTec - Instituto Brasileiro de Tecnologia do Couro 
IBB - Instituto by Brazil

NBR - “Acrylonitrile-Butadiene Rubber” - Copolímero de acrilonitrilo e de butadieno

NCM - Nomenclatura Comum do Mercosul

NR - "Natural Rubber" - Borracha Natural

PES - "Polyester fibers" - Fibra de poliéster

PET - "Polyethylene Terephthalate" - Poli tereftalato de etileno

phr ou pcr - "parts per hundred of resin" - partes por cem partes de resina

PIB - Produto Interno Bruto

PNRS - Política Nacional de Resíduos Sólidos

PU - "Polyurethane" - Poliuretano

PVC - "Polyvinyl Chloride" - Policloreto de Vinila

REACH - "Registration, Evaluation, Authorisation and Restriction of Chemicals" Registro, Avaliação, Autorização e Restrição de Produtos Químicos pela Agência Europeia dos Produtos Químicos (ECHA)

SBR - "Styrene Butadiene Rubber" - Borracha Estireno Butadieno

TGA - "Thermo Gravimetric Analysis)" - Análise Termogavimétrica

TR - "Thermoplastic Rubber" - Borracha Termoplástica 


\section{SUMÁRIO}

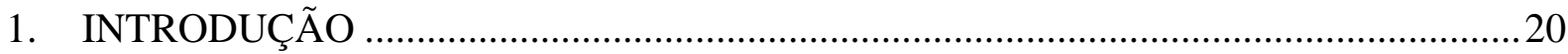

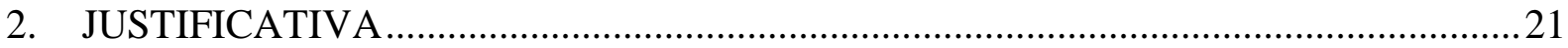

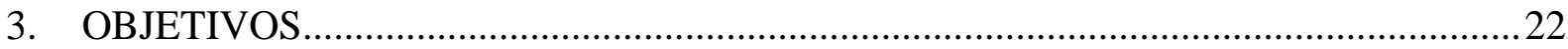

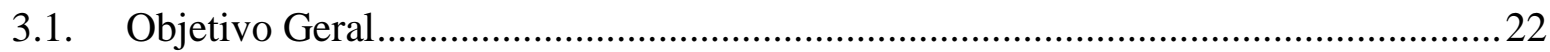

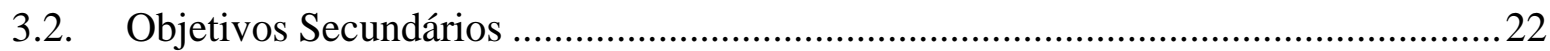

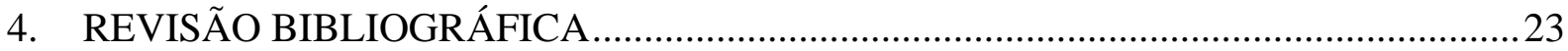

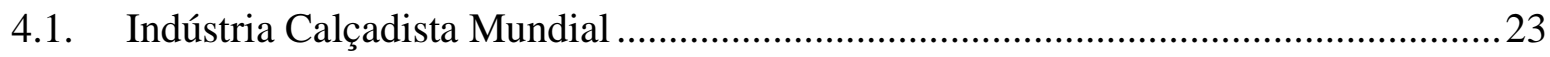

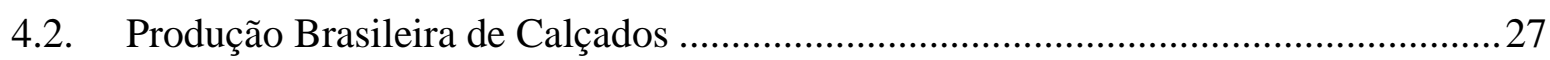

4.2.1. Breve histórico da indústria calçadista brasileira ...........................................2

4.2.2. Dados produção e exportação brasileira de calçados ........................................28

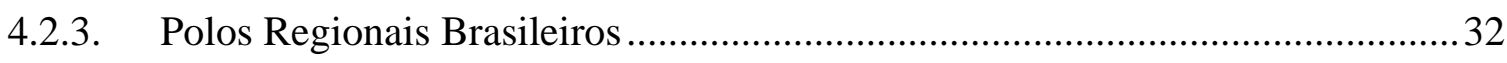

4.2.4. Histórico dos materiais empregados na indústria calçadista brasileira ..............37

4.3. Componentes de Calçados ...............................................................................4

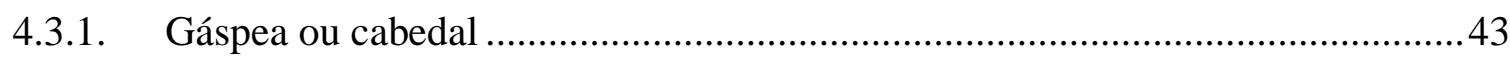

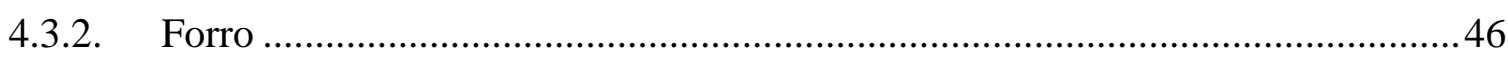

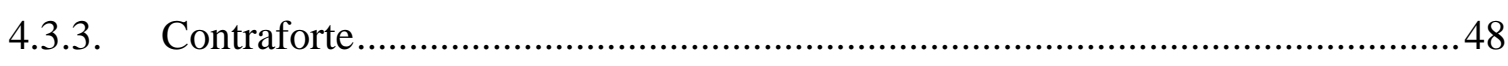

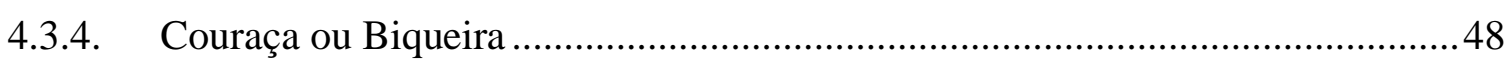

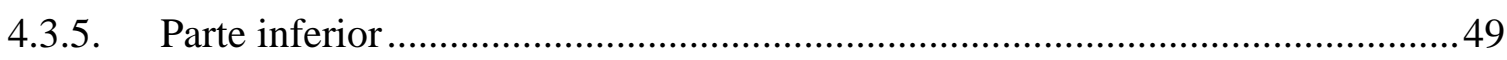

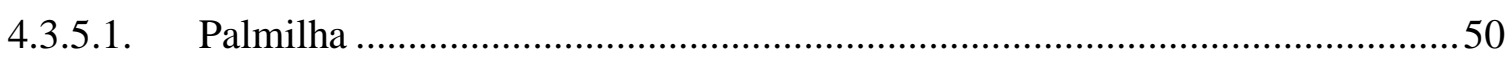

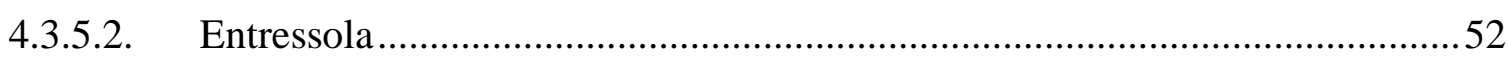

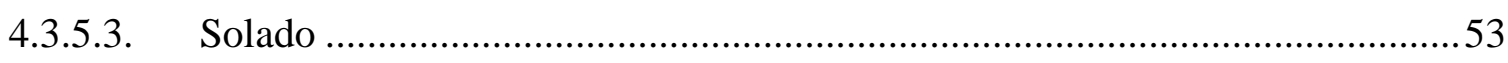

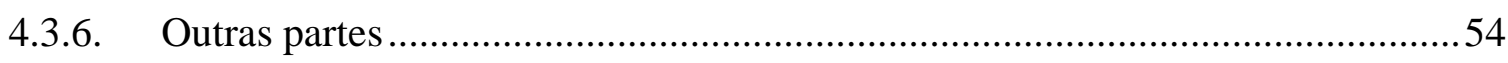

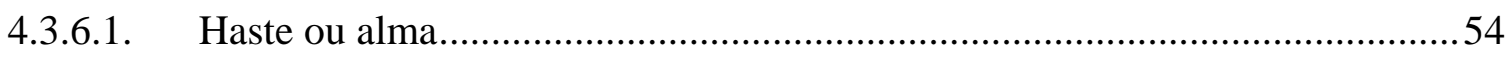

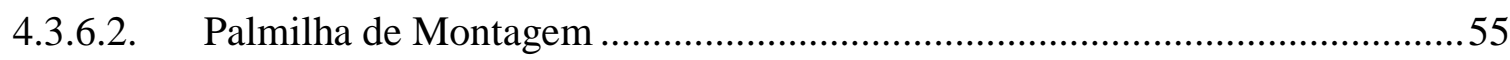

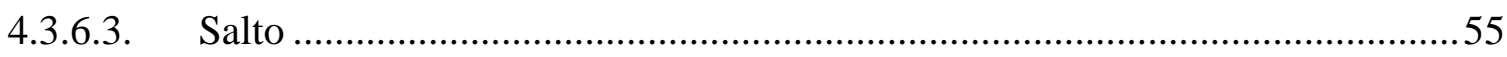

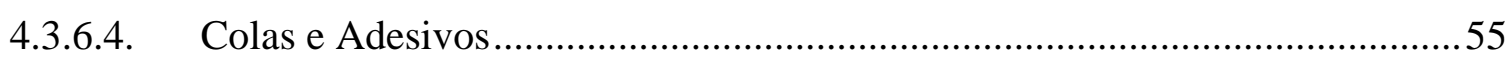

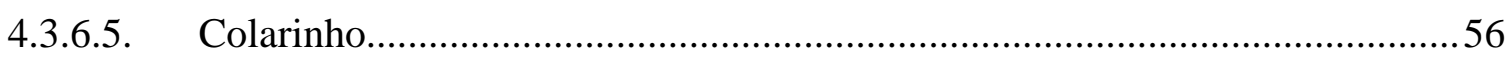

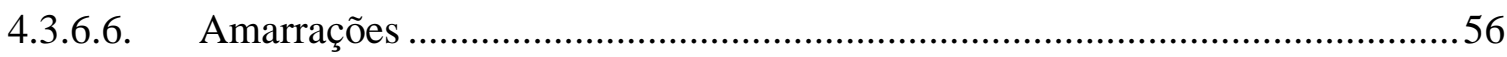

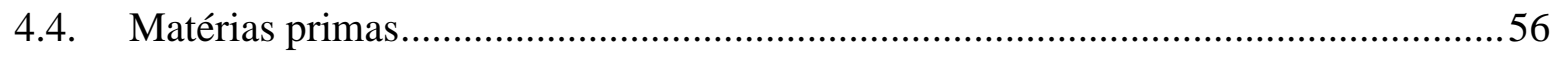

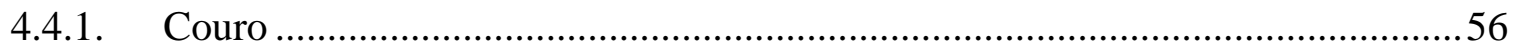

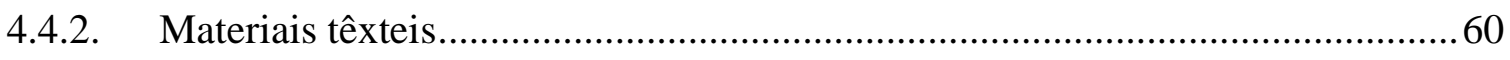

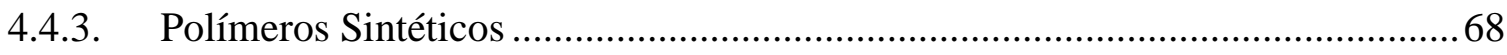




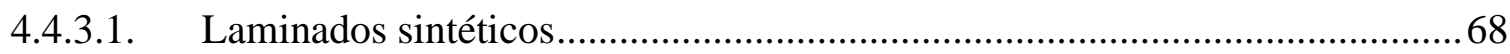

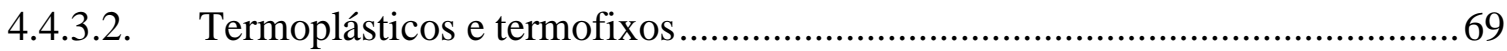

4.5. A influência dos materiais no conforto do calçado durante a marcha .......................71

4.6. Impactos Ambientais da Indústria Calçadista ............................................................ 73

4.6.1. Ciclo de Vida de Produtos Calçadistas ................................................................ 73

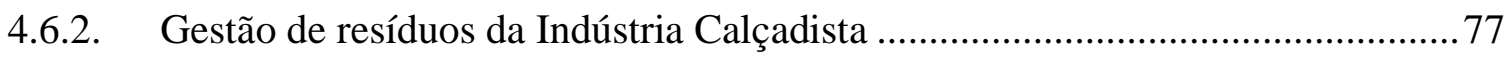

4.6.3. A relação do setor calçadista brasileiro e a sustentabilidade .............................. 81

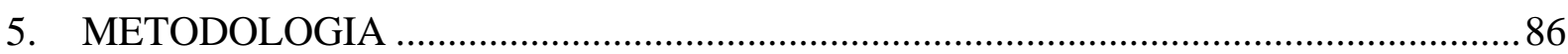

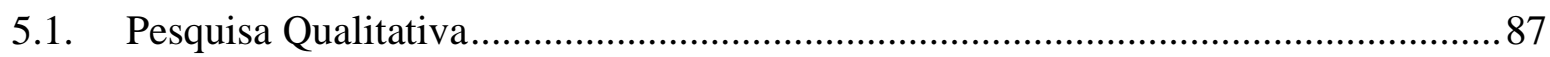

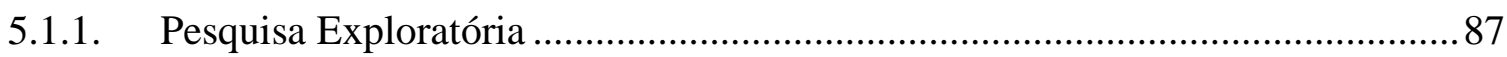

5.1.2. Outras formas de coleta de dados por forma direta ........................................ 88

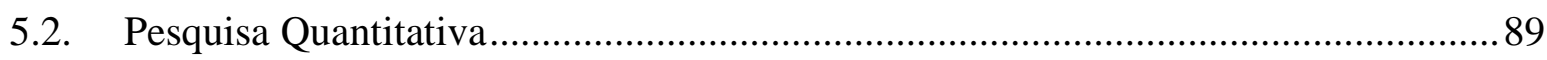

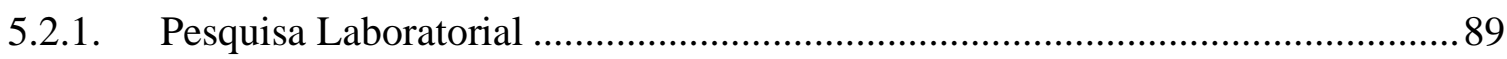

5.2.2. Instalações para realização dos experimentos de preparação das fibras, processamento, caracterização da fibra e caracterização do compósito.............................90

5.2.3. Etapas do desenvolvimento do compósito.........................................................90

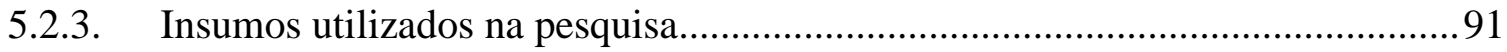

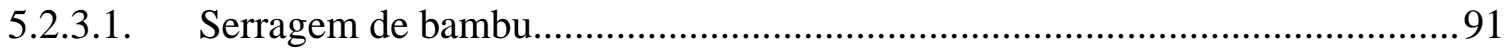

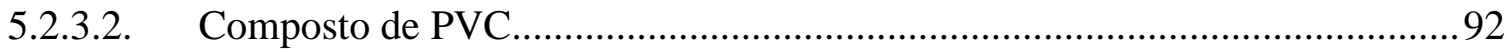

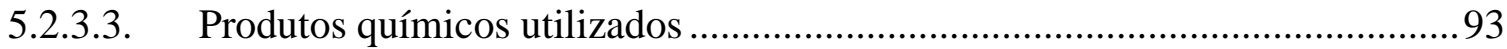

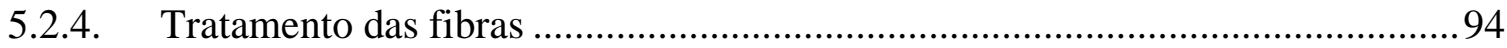

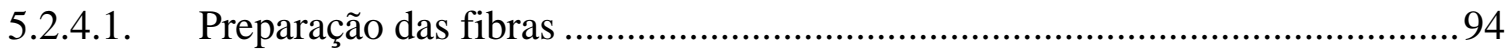

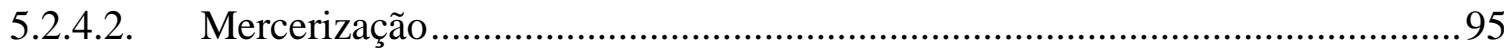

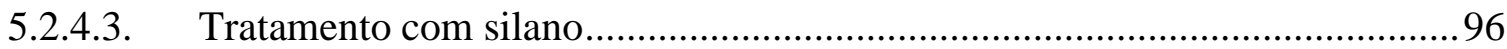

5.2.5. Maquinário utilizado para a conformação do compósito ...................................97

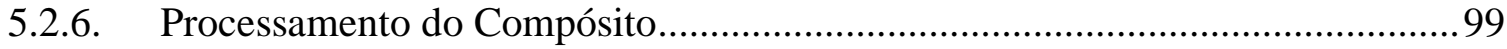

5.2.7. Caracterização da serragem de bambu ........................................................ 101

5.2.7.1. Espectroscopia no infravermelho por transformada de Fourier (FTIR) ........101

5.2.7.2. DSC (Differential Scanning Calorimetry) - Análise Térmica Diferencial... 102

5.2.7.3. TGA (Thermo Gravimetric Analysis) - Análise Termogavimétrica ............. 103

5.2.8. Caracterização mecânica e morfológica dos compósitos .................................. 104

5.2.8.1. Tensão, alongamento e módulo de elasticidade........................................... 104

5.2.8.2. Análise Morfológica em Microscópio Eletrônico de Varredura (MEV) ....... 107

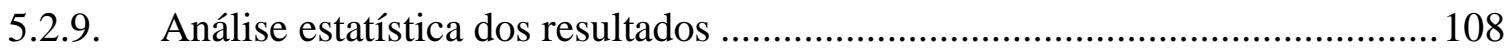

5.2.9.1. Média, desvio padrão e coeficiente de variação ........................................... 108 


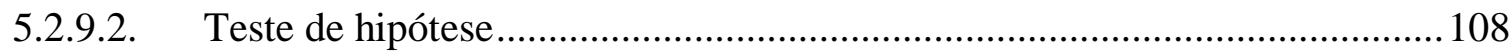

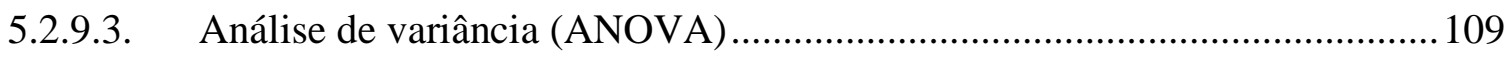

5.2.9.4. Análise dos resíduos ............................................................................... 110

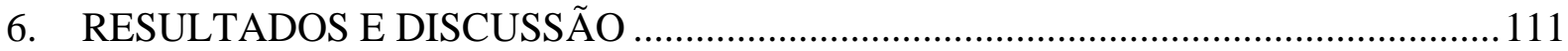

6.1. Entrevistas com empresas participantes da Feira Inspiramais ..................................111

6.1.1. Análise dos dados obtidos a partir da busca nos sites das empresas participantes

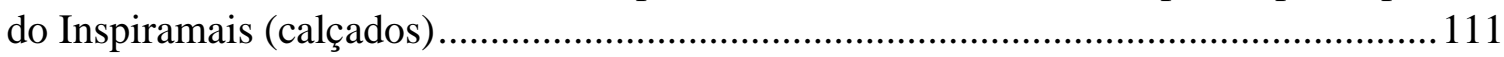

6.1.2. Dados obtidos a partir das três entrevistas realizadas durante a feira Inspiramais

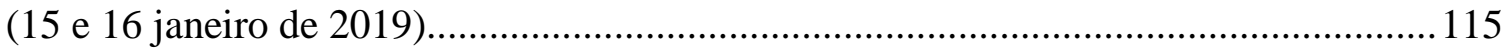

6.1.2. Resultado das duas entrevistas realizadas com visitas técnicas nas empresas .117

6.2. Selo "Origem Sustentável" e sua contribuição para o setor ....................................... 120

6.2.1. Estrutura do selo "Origem Sustentável".......................................................... 120

6.2.2. Resultado entrevista com a responsável do Instituto by Brazil .........................122

6.2.2.1. Construção do selo "Origem Sustentável” e adesão das empresas.................122

6.2.2.2. Visão sobre a contribuição do selo para o setor............................................... 124

6.2.2.3. O impacto da sustentabilidade na cadeia brasileira de calçados segundo o IBB 125

6.2.3. Apresentação do selo Origem Sustentável na palestra "Sustentabilidade: é hora de avançar"

6.2.4. Dados obtidos a partir das duas entrevistas com empresas que implantaram o selo Origem Sustentável

6.3. Pesquisa Laboratorial - formulação de solado de PVC com inserção de serragem de bambu 131

6.3.1. Etapa Preparatória

6.3.1.1. Disciplina - Processamento de Termoplástico ................................................ 131

6.3.1.2. Viniltec - Conferência Tecnológica sobre o PVC no Brasil - 20.03.2020 ...131

6.3.1.3. Plástico Brasil - 25.03.2019- São Paulo Expo

6.3.1.4. Visita do sr. Emerson Madaleno (Braskem) ao laboratório Unifesp (campus

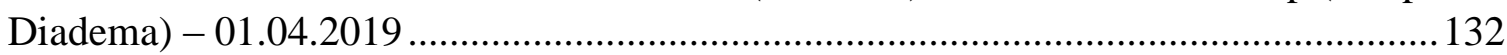

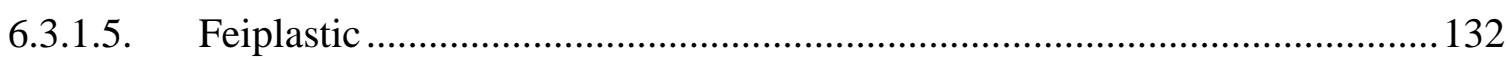

6.3.2. Definições para PVC e compósitos para solados ............................................... 134

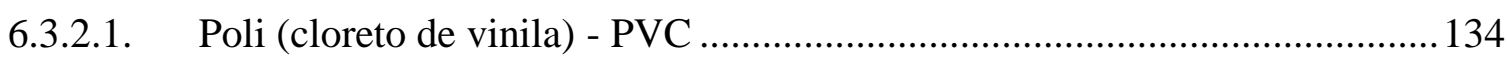

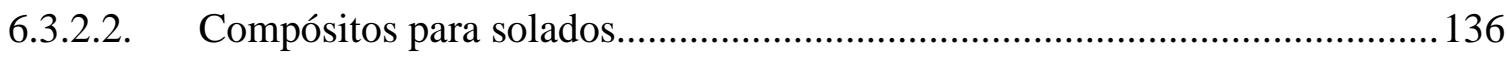

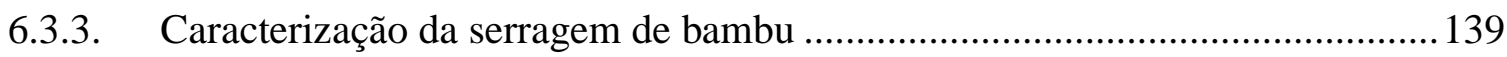

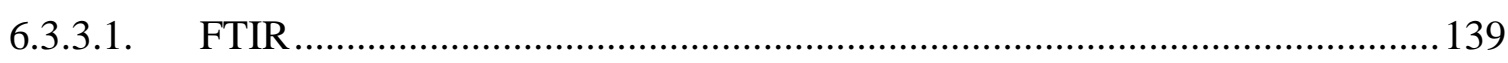

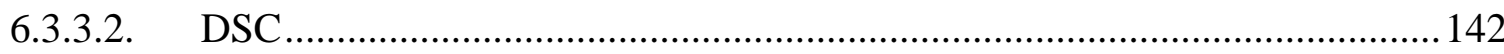




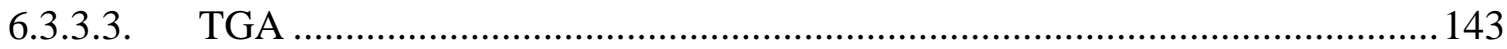

6.3.4. Caracterização morfológica do compósito …………………………………........ 144

6.3.5. Caracterização mecânica do compósito................................................................. 146

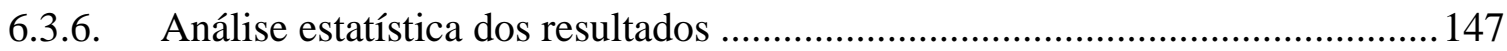

6.3.6.1. Influência do material compósito na carga máxima ........................................ 148

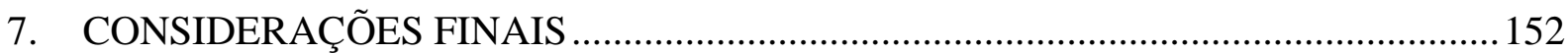

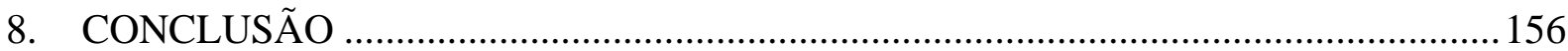

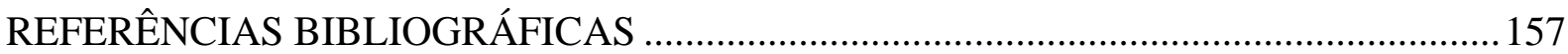

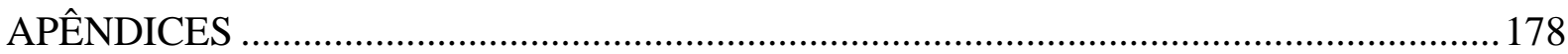

APÊNDICE A - Roteiro da Entrevista das Empresas A, B e C.......................................... 178

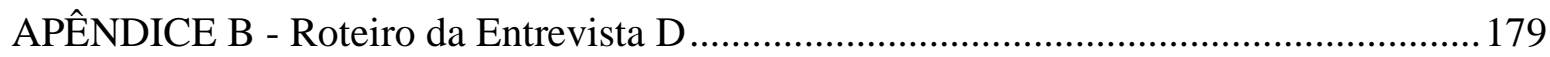

APÊNDICE C - Resultado da Entrevista Empresa E........................................................180

APÊNDICE D - Resultado Entrevista sra. Linda Pienis (IBB).............................................183

APÊNDICE E - Resultado Entrevista Cipatex.............................................................186

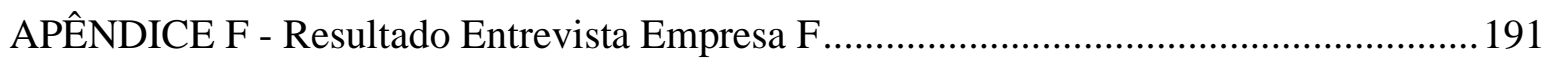

APÊNDICE G - Empresas do Inspiramais com ações sustentáveis....................................... 195

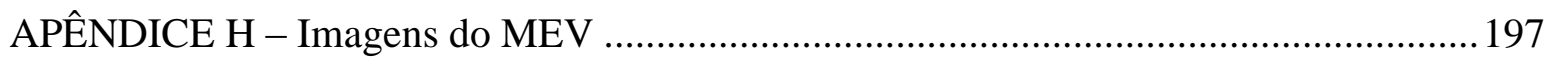

APÊNDICE I - Dados resultantes dos testes de dinamômetro............................................. 198

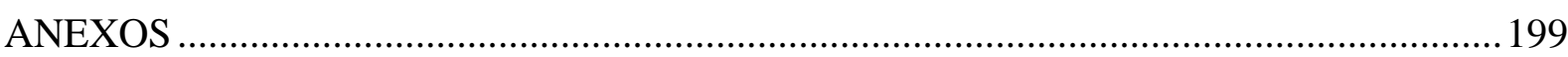

ANEXO A - Lista de Classificação Fiscal de Mercadorias - Tabela de NCM (Nomenclatura Comum do Mercosul) 199

ANEXO B - Princípios, Critérios e quantidade de Indicadores do Selo Origem Sustentável 202

ANEXO C - Programação do evento "Sustentabilidade: é hora de avançar". .204 


\section{INTRODUÇÃO}

O aumento de consumo de bens semiduráveis foi impulsionado, nos últimos anos, pelo maior ritmo de lançamentos do varejo e por novos comportamentos da sociedade, que desejam o novo e buscam, a cada temporada, o produto mais atualizado (GAZZOLA et al., 2020). No setor de vestuário, o ritmo acelerado de novos produtos reduz drasticamente o ciclo de vida dos produtos (VAN RENSBURG; NKOMO; MKHIZE, 2020). Apesar disso, mudanças na conscientização mundial sobre os impactos ambientais estão ocorrendo e é possível observar consequências no varejo de moda, a partir da ampliação de produtos sustentáveis, nas principais marcas de vestuário (BUCKLOW; PERRY; RITCH, 2017; GUO; CHOI; SHEN, 2020).

A produção de calçados segue esse ritmo acelerado, inclusive no Brasil, que é o quarto maior produtor mundial do segmento (900 milhões de pares/ano) e se mantém nas primeiras posições há alguns anos. Historicamente, o setor tem sido marcado por especialização de mão de obra, mudanças regionais e substituição dos materiais; impulsionados pela concorrência internacional para a busca da redução do custo produtivo (CASTRO; MOREIRA, 2009a; KOHAN et al., 2019). Mudanças significativas ocorreram nos materiais empregados nos calçados no Brasil, como a ampliação do uso de polímeros sintéticos, que mudou a percepção dos usuários, que antes atribuíam o toque seco e duro aos calçados plásticos, quando comparados aos feitos em couro bovino, que são confortáveis e transpiráveis. Com o passar do tempo, houve a melhoria nos materiais sintéticos, deixando-os mais macios e permeáveis. Contudo, o que de fato motivou a ampliação de uso desses materiais foi o custo-benefício (DE SMET et al., 2020; TEIXEIRA; ROMANO; ALVEZ-FILHO, 2014). Além do mais, a produção de um calçado envolve a possibilidade de escolha de mais de 40 tipos de componentes, entre os principais: tecidos, diversos polímeros em solados, metais em enfeites, adesivos, pigmentos, linhas de costura, laminado sintético, papelão etc. (MOTAWI, 2018).

Dessa forma, para abranger os temas a serem desenvolvidos para o presente trabalho foram estruturados seis capítulos: (i) introdução; (ii) justificativa; (iii) objetivos; (iv) revisão bibliográfica, nas quais se encontram o contexto histórico mundial e brasileiro, estrutura e função do calçado, componentes e ciclo de vida do produto e impactos ambientais; (v) metodologia; (vi) resultados e discussão, abordando componentes sustentáveis, selo Origem Sustentável, desenvolvimento de compósito de policloreto de vinila (PVC) empregando serragem de bambu sem tratamento, mercerizada e com tratamento de silano; (vii) conclusões obtidas no presente trabalho e sugestões para estudos futuros. 


\section{JUSTIFICATIVA}

O setor calçadista, no Brasil, já é consolidado por sua história, por polos produtivos, produção com variedade e volume e por marcas de sapatos, conhecidas no país e no mundo. Por sua vez, recentemente, houve o surgimento de novas empresas, no mercado nacional, com viés na sustentabilidade, só que elas, em sua maioria, são pequenas e direcionadas a mercados específicos. A discussão de sustentabilidade tem se ampliado cada vez mais, e não se tem conhecimento ainda, se a cadeia, como um todo, a que fabrica grandes volumes, já adotou essas práticas associadas à sustentabilidade.

A pressão para a produção de um produto mais orientado para a busca de redução de impactos ambientais tem influenciado diversas iniciativas: no desenvolvimento de matérias primas menos poluentes, processos produtivos mais sustentáveis e soluções na gestão de resíduos pós consumo, como os processos de reciclagem e geração de energia. Tais iniciativas têm sido apresentadas há algum tempo, mas, de fato, o que tem sido feito dentro das indústrias e empresas, não foi averiguado mais detalhadamente. Também é importante pesquisar e compreender o grau de adesão das empresas ao discurso e práticas sustentáveis.

Essa preocupação teve origem na experiência da autora, vinda do mercado profissional, na prática no departamento de desenvolvimento em indústrias têxteis, que permitiu vivenciar as questões práticas de mercado e trazer alguns questionamentos reais para a academia. $\mathrm{O}$ retorno ao mestrado, na faculdade que se graduou, dá continuidade aos laços do passado e para novas possibilidade de busca de conhecimento e pesquisa.

Também no presente estudo, houve a oportunidade de desenvolver compósito de PVC com serragem de bambu, o que permitiu ampliar os conhecimentos sobre os materiais aplicados na área de calçados.

Verifica-se que há espaço para pesquisa, em averiguar o que está sendo empregado no mercado brasileiro de calçados, relacionar com as melhorias já desenvolvidas e poder contribuir para os setores, de alguma maneira, ao apresentar e estudar novas soluções. 


\section{OBJETIVOS}

\subsection{Objetivo Geral}

Estudar as ações sustentáveis das empresas brasileiras de componentes de calçados; verificar o que compõe o selo nacional "Origem Sustentável” e sua contribuição para o setor; e, também, realizar desenvolvimento do compósito de PVC com inserção de serragem de bambu e avaliar suas propriedades.

\subsection{Objetivos Secundários}

1) Identificar quais e quantas empresas brasileiras de componentes se enquadram nos critérios das ações sustentáveis em: material, processo, reuso, reciclagem, social e certificação.

2) Identificar a variedade de ações sustentáveis de cada critério avaliado descrito no item anterior.

3) Verificar o funcionamento da certificação nacional de sustentabilidade no segmento calçadista - selo Origem Sustentável.

4) Verificar os benefícios adquiridos com a certificação Origem Sustentável pelas empresas, na dimensão ambiental.

5) Realizar desenvolvimento de compósito de PVC com serragem de bambu.

6) Verificar as propriedades mecânicas e morfológicas resultantes do material produzido. 


\section{REVISÃO BIBLIOGRÁFICA}

\subsection{Indústria Calçadista Mundial}

O mercado calçadista mundial tem passado por mudanças, desde a década de 1990, devido ao desenvolvimento da cadeia de valores global, que influenciou ciclos de vidas de produto mais curtos, novas configurações na forma de produzir, no relacionamento entre os fornecedores e nas localizações geográficas (BELSO-MARTÍNEZ, 2008; DUNOFF; MOORE, 2014). Antes desse período, grandes indústrias normalmente eram verticalizadas, isto é, quando todas as etapas da produção calçadista principalmente com material de couro eram feitas internamente: desenvolvimento do modelo do calçado, corte, preparação da costura, costura ou preparação da união, montagem e acabamento; isso caracterizava a mão obra especializada um lento processo de criação dos produtos (BELSO-MARTÍNEZ, 2008).

O resultado dessas mudanças das configurações foi o desenvolvimento dos polos regionais (clusters) com segmentação da etapa produtiva. Assim, parte dos processos passa a ser terceirizada ou os fornecedores vendem componentes prontos, que poderia ser a melhores custos, devido à especialização e produção de grandes volumes (BELSO-MARTÍNEZ, 2008; GUNAWAN; JACOB; DUYSTERS, 2015). Além da fragmentação, houve a realocação geográfica das indústrias, na busca de menores custos de mão de obra, isso também permitiu a penetração em mercados estrangeiros; como exemplo, a China, em 2004, ou até passaram a produzir em países como a Nigéria (WANG, 2010).

A China, atual líder no mercado calçadista em produção e exportação, também passou por modificações nas últimas décadas. A ilha de Wenzhou foi o local pioneiro no país e, especializou-se na produção de solado injetado e também vulcanizado (usando borracha no solado); mas em geral, até a década de 1990 a produção havia ficado estagnada, devido à falta de mão de obra qualificada (WANG, 2010). Assim, parte das empresas migraram para outras cidades da costa leste. Porém, houve uma retomada no distrito de Lucheng, parte terrestre da província de Wenzhou, o que acabou fortalecendo as alianças com as marcas diversas multinacionais da Itália, Alemanha, Japão, Brasil; obrigando mudanças ambientais e tornando a região responsável por um quarto da produção chinesa.

Os maiores produtores mundiais de calçados são frequentemente os mesmos países que se intercalam nos primeiros lugares (Tabela 1), mas sempre a com liderança da produção da China, correspondendo a 11,4 bilhões de pares/ano, uma parcela de 53\% (2017) da produção 
em volume (milhões de pares) do total produzido no mundo, sendo que $72 \%$ é destinado à exportação, o que corresponde cerca de 8,25 bilhões de pares (Tabelas 1 e 2) (ABICALÇADOS, 2018).

Tabela 1 - Principais países produtores de calçados (milhões de pares)

\begin{tabular}{lccrc}
\hline País & $\mathbf{2 0 1 5}$ & $\mathbf{2 0 1 6}$ & $\mathbf{2 0 1 7}$ & Variação 2016-2017 \\
\hline China & 11.322 & 11.116 & 11.410 & $2,6 \%$ \\
Índia & 2.698 & 2.797 & 2.868 & $2,5 \%$ \\
Vietnã & 927 & 971 & 1.255 & $29,2 \%$ \\
Brasil & $\mathbf{9 1 2}$ & $\mathbf{9 3 3}$ & $\mathbf{9 4 3}$ & $\mathbf{1 , 1 \%}$ \\
Indonésia & 733 & 771 & 810 & $5,1 \%$ \\
Nigéria & 406 & 415 & 429 & $3,2 \%$ \\
Paquistão & 251 & 258 & 265 & $2,8 \%$ \\
México & 250 & 253 & 264 & $4,4 \%$ \\
Tailândia & 226 & 231 & 238 & $3,0 \%$ \\
Itália & 191 & 188 & 190 & $1,3 \%$ \\
Outros & 2.561 & 2.660 & 2.808 & $5,6 \%$ \\
Total & $\mathbf{2 0 . 4 7 7}$ & $\mathbf{2 0 . 5 9 2}$ & $\mathbf{2 1 . 4 8 0}$ & $\mathbf{4 , 3 \%}$ \\
\hline \multicolumn{5}{c}{ Fonte: (WSR, apud ABICALÇADOS, 2019, p. 8) }
\end{tabular}

Tabela 2 - Principais países exportadores de calçados (milhões de pares)

\begin{tabular}{lcccc}
\hline País & $\mathbf{2 0 1 5}$ & $\mathbf{2 0 1 6}$ & $\mathbf{2 0 1 7}$ & Variação 2016-2017 \\
\hline China & 8.341 & 8.049 & 8.258 & $2,6 \%$ \\
Vietnã & 617 & 654 & 926 & $41,7 \%$ \\
Indonésia & 366 & 387 & 407 & $5,2 \%$ \\
Alemanha & 237 & 252 & 281 & $11,3 \%$ \\
Bélgica & 239 & 236 & 249 & $5,4 \%$ \\
Itália & 208 & 206 & 216 & $4,8 \%$ \\
Reino Unido & 191 & 213 & 194 & $-9,2 \%$ \\
Índia & 177 & 181 & 185 & $2,2 \%$ \\
Países Baixos & 142 & 146 & 181 & $23,3 \%$ \\
Espanha & 158 & 160 & 164 & $2,5 \%$ \\
Brasil (11 $\left.{ }^{\circ}\right)$ & $\mathbf{1 2 4}$ & $\mathbf{1 2 6}$ & $\mathbf{1 2 7}$ & $\mathbf{1 , 2 \%}$ \\
Outros & 1.252 & 1.276 & 1.315 & $3,1 \%$ \\
Total & $\mathbf{1 2 . 0 5 3}$ & $\mathbf{1 1 . 8 8 6}$ & $\mathbf{1 2 . 5 0 2}$ & $\mathbf{5 , 2 \%}$ \\
\hline \multicolumn{5}{c}{ Fonte: (WSR, apud ABICALÇADOS, 2019, p.11) }
\end{tabular}

Os principais parceiros na exportação chinesa são os Estados Unidos, Europa, Japão e Rússia; porém, devido aos ajustes da estrutura de mercado, diversos países vinham impondo barreiras alfandegárias, como América do Sul e por muitos anos a Europa Isto pode ser visto na Tabela 2 de volumes (em milhões) de pares exportados por diversos países europeus que produzem nos países asiáticos e exportam ao redor do mundo (ZHANG, 2018). 
Mesmo assim, em diversos países da Europa sancionaram medidas para impedir a comercialização interna calçados chineses, por isso fora impostos barreiras alfandegárias contra a importação da China e Vietnã a partir de 2006, estendidos em 2009 e 2016, medidas tomadas principalmente pela Itália, Espanha e Portugal e, depois, Polônia, Eslováquia e Romênia. Entretanto, países como Holanda, Bélgica, Escandinávia e Inglaterra foram contra, por ter em parte de suas produções de calçado na China (DUNOFF; MOORE, 2014; HOAI; TOAN; VAN, 2017). Estas ações antidumping restringiram especificamente o calçado com matéria prima predominante em couro bovino, por isso a Itália tinha grande interesse nestas ações, pois representava cerca de $46 \%$ da produção do mercado comum europeu deste segmento de produto (2006) e não incluía os tênis esportivos, que eram os modelos que outros países, como a Alemanha tinha grande interesse de produção nos países asiáticos (DUNOFF; MOORE, 2014).

A indústria calçadista italiana tem tradição nos produtos em couro, com alto padrão de nível de exportação por ter tecnologia, design com bom acabamento de produtos feitos à mão e conforto. Os calçados do país sempre foram bem reputados entre os consumidores e conseguem manter um preço médio por par de calçado exportado (ZHANG, 2018). A Tabela 3 ilustra a constância do preço do calçado italiano no mercado exportador.

Tabela 3 - Unidade de preço de calçado (em US\$/par) exportado dos principais países do mundo (2008-2016)

\begin{tabular}{ccccccc}
\hline Ano/País & China & Itália & Alemanha & França & Indonésia & Índia \\
\hline 2008 & 10,70 & 25,00 & 22,76 & 30,12 & 22,76 & 13,13 \\
2009 & 23,15 & 24,93 & 23,15 & 30,28 & 23,15 & 13,34 \\
2010 & 10,70 & 24,70 & 26,82 & 28,68 & 26,82 & 26,82 \\
2011 & 11,88 & 27,53 & 26,79 & 26,79 & 26,79 & 14,52 \\
2012 & 12,33 & 26,11 & 23,93 & 30,24 & 23,93 & 13,48 \\
2013 & 12,43 & 28,04 & 23,93 & 30,66 & 23,93 & 14,55 \\
2014 & 23,21 & 29,17 & 23,21 & 26,86 & 23,21 & 16,24 \\
2015 & 26,24 & 25,27 & 26,24 & 16,13 & 42,67 & 14,16 \\
2016 & 15,32 & 25,89 & 15,31 & 17,01 & 15,33 & 15,21 \\
\hline $\begin{array}{c}\text { Preço da } \\
\text { unidade }\end{array}$ & \multirow{2}{*}{15,32} & 26,29 & 23,57 & 26,31 & 25,40 & \multirow{2}{*}{15,78} \\
\hline
\end{tabular}

Fonte: (ZHANG, 2018, p.189)

A Indonésia, o quarto país mais populoso do mundo, com foco na exportação tem o produto calçadista com preço médio elevado e qualidade no mercado exportador (Tabela 3). O país tem investido em código de conduta nas empresas para assegurar direitos dos trabalhadores e equipamentos seguros, mantendo inclusive essa rigidez com os fornecedores (BARTLEY; 
EGELS-ZANDÉN, 2015). Estas exigências foram feitas pelas grandes marcas (Quadro 1), que terceirizam a produção no país e, assim, tornou-se uma referência em qualidade e em variedade, produzindo desde esportivos a botas militares (GONI; KADARUSMAN, 2016). Essas marcas alternam a produção entre a Indonésia, a China e o Vietnã; apesar destes dois últimos serem inferiores em qualidade e, por conta das sanções europeias contra eles, enquanto a primeira expandiu sua exportação.

Quadro 1- Principais marcas mundiais que produzem calçados na Indonésia

\begin{tabular}{|c|c|c|c|c|c|}
\hline Adidas & Cerini & Fly & Michelin & Ananda Singgih & GAP \\
\hline Mod 8 & Chatham & Andre Valentino & Converse & New Era & Nike \\
\hline Sledgers & Hush Puppies & Oakley & Specs & Deichmann & Kappa \\
\hline Osh Kosh & Starmon & Bata & Diadora & Sunly & Beltoni \\
\hline Dockers & Kickers & Pakalolo & Piero & Tomkins & Benetton \\
\hline Eagle & Pierre Cardin & Tommy & Hilfiger & Bertinni & Ecco \\
\hline Lacoste & Reebok & Bubblegummers & Ellesse & Rockport & Uniform \\
\hline Logo & Marie Claire & Fila & Salamander & YongkiKomaladi & Carvil \\
\hline
\end{tabular}

Fonte: TREDA (2009, apud GONI; KADARUSMAN, 2016, p.445)

Ao contrário da Indonésia, o mercado calçadista do Vietnã é dominado pela baixa valorização do funcionário, pagando inclusive o menor valor/hora, cerca de U\$0,48-0,69/hora do trabalhador para fabricação, este país concorre diretamente com a China em quantidade de produção (Tabela 1) e exportação (Tabela 2), devido aos menores custos com funcionários e no foco em menor preço e qualidade (LAN; HONG, THI, 2016). Um par de tênis da Nike produzido no Vietnã tem como custo de produção a cerca de U\$6,00, significa uma parcela de apenas $10 \%$ do preço final da marca. As exportações do país têm o predomínio no uso de intermediários, compradores estrangeiros ou donos das marcas, e estes ficam com a responsabilidade de distribuir os sapatos aos consumidores finais. Como consequência, os produtores vietnamitas não têm contato com as marcas e "toda a tecnologia e conhecimento acerca das atividades não pode ser transferida" (LAN; HONG, THI, 2016, p.62) para o país.

A Índia é o segundo maior produtor de calçados do mundo, depois da China (Tabela 1), com 13,65\% da produção global, sendo que cerca de $45 \%$ dos produtos são feitos de couro bovino e próximo de $95 \%$ da produção é destinada à demanda doméstica (HUSSAIN, 2016). A falta de investimento no setor possibilitou que a China tivesse, nos últimos dez anos, dez vezes mais investimentos que a Índia. Mesmo com a defasagem nos direitos trabalhistas, houve um crescimento na exportação entre 2009-10 e 2013-14, quando houve um crescimento de 13,82\% quando gigantes varejistas, como a Wal-Mart, iniciaram parceria na distribuição (HUSSAIN, 
2016). Outro fator que tem mudado o setor no país é o número de empresas com design sustentável, alinhado com conforto e novas possibilidades em customização e, ainda, aponta possibilidades de crescimento do consumo no mercado interno (DWIVEDI; CHAKRABORTY, 2017).

O Brasil, assim como a Índia, mesmo retomando o crescimento na exportação de calçados nos últimos anos, ainda tem predomínio na demanda do mercado interno e, por esse motivo, vários desdobramentos serão analisados a seguir. Além do mais, o país está estruturado em polos regionais, e o setor tem passado por reestruturação e tentado diversificar os produtos, diante da crise que perdura há alguns anos.

\subsection{Produção Brasileira de Calçados}

4.2.1. Breve histórico da indústria calçadista brasileira

A origem da produção brasileira de calçados tem estreita relação com a imigração europeia no país. Os imigrantes alemães se instalaram na região sul (no estado do Rio Grande do Sul) e inauguraram o primeiro local rudimentar de manufatura de selas e calçados no final do século XIX. Em seguida, no início do século XX, imigrantes italianos que se instalaram próximo da cidade de Franca (interior de São Paulo), após a decaída da produção agrícola do café na região, optaram a trabalharem no ramo calçadista, uma vez que já tinham experiência em seu país de origem. No sul, com o advento da guerra do Paraguai (1864-1870), foi necessário ampliar e melhorar a qualidade manufatureira em fazer os calçados, que era ainda toda artesanal (FLORES, 2018; KAYSER, 2008).

O advento da máquina de costura foi um evento importante e várias outras melhorias tecnológicas foram feitas até 1920, o que possibilitou que a produção se tornasse um pouco mais industrializada. Apenas em 1960, após 40 anos de estagnação, que a produção ganhou volume e também passou a exportar (FLORES, 2018). A exportação se intensificou com investimentos em produtividade, tecnologia e incentivos governamentais através de reduções de taxas, assim, entre 1970 e 1990 houve uma alavancada na exportação. Em 1973, foram vendidos 22 milhões de pares com um ganho de US\$ 93 milhões, já no ano de 1993 foram exportados 93 milhões de pares e US\$ 682 milhões, os maiores ganhos ocorreram em 1993 em 201 milhões de pares e US\$ 1,846 milhões, sendo que cerca dois terços eram direcionados ao mercado norte americano (BNDS, 2006; FLORES, 2018) 
Durante a década de 1990, houve uma drástica redução das exportações brasileiras, grande parte por questões internas, devido a sobrevalorização cambial e a abertura de mercado e pela grande influência da entrada da China no ambiente competitivo internacional (AZEVEDO, 2001).

Após essas mudanças, o setor calçadista brasileiro reagiu para reduzir o custo de produção: as regiões produtoras mudaram para obter benefícios fiscais e encontrar uma força de trabalho mais barata (CAVALHEIRO; BRANDAO, 2017). Outra estratégia para reduzir o custo de produção foi a substituição da matéria-prima dos calçados, a fim de substituir o couro (KOHAN et al., 2019). Tais mudanças serão apresentadas nos próximos itens.

\subsubsection{Dados produção e exportação brasileira de calçados}

Dados recentes mostram a produção brasileira de calçados estável, entre 2016 e 2017 , com taxa a cerca de $1,1 \%$ de crescimento. Conforme Associação Brasileira das Indústrias de Calçados (Abicalçados), o Brasil é o $4^{\circ}$ maior produtor de calçados no mundo (Tabela 1), com a produção de 943 milhões de pares, em 2017, sendo ultrapassado apenas pela China, Índia e Vietnã (ABICALÇADOS, 2018).

Por sua vez, em consumo de pares, em 2015, o brasileiro comprou cerca de 4,2 pares per capita totalizando a quantidade de 851 milhões de pares/ano, sendo o $4^{\circ}$ país de maior consumo, após China, Índia e EUA (ABICALÇADOS, 2018). A exportação setorial no país obteve crescimento em 2017, após 3 anos consecutivos de queda, totalizou 127,1 milhões de pares que geraram 1,09 bilhões de dólares, alta em 1,2\% em quantidade de pares e, em receita, 9,3\%, comparado aos valores no ano de 2016 (ABICALÇADOS, 2018).

Os principais destinos dos calçados exportados, com valores referentes ao período de janeiro a novembro de 2017, foram: EUA (com 9,88 milhões de pares por US\$ 170,18 milhões, ambos em queda com 13,3\% em volume e de 12,7\% em receita), segundo a Argentina (com 10,83 milhões de pares por US\$138,8 milhões, altas de $18,4 \%$ e de $30,2 \%$ ) e terceiro, o Paraguai (com 12,85 milhões de pares por US\$ 70,26 milhões, queda de 6,5\% em volume e alta $60 \%$ em dólares em relação a 2016). Apesar do destaque positivo a associação apontou que os dados de crescimento não foram maiores, devido à queda de valores das exportações americanas e, também, com a taxação dos produtos brasileiros no Equador, que, desde setembro, tem aplicado uma tarifa de $10 \%$ sobre o valor mais US\$6,00 por par (ABICALÇADOS, 2018). 
A balança comercial de calçados no Brasil é apresentada com saldo positivo na Figura 1 com dados de 2014-2019, com tendência de crescimento entre anos 2016-2018, devido a redução da importação de pares de calçados. Um dos prováveis motivos desse movimento seria variação cambial, a qual é referente à cotação do dólar americano, uma vez que a partir de 2016 houve um crescimento significativo diante o ano anterior (Tabela 4), coincidindo com o ano em que ocorreu a redução da importação. Além disso, a saturação do mercado doméstico também é apontada por uma razão da iniciativa à exportação (CAMPOS et al., 2018).

Figura 1 - Balança comercial de calçados no Brasil

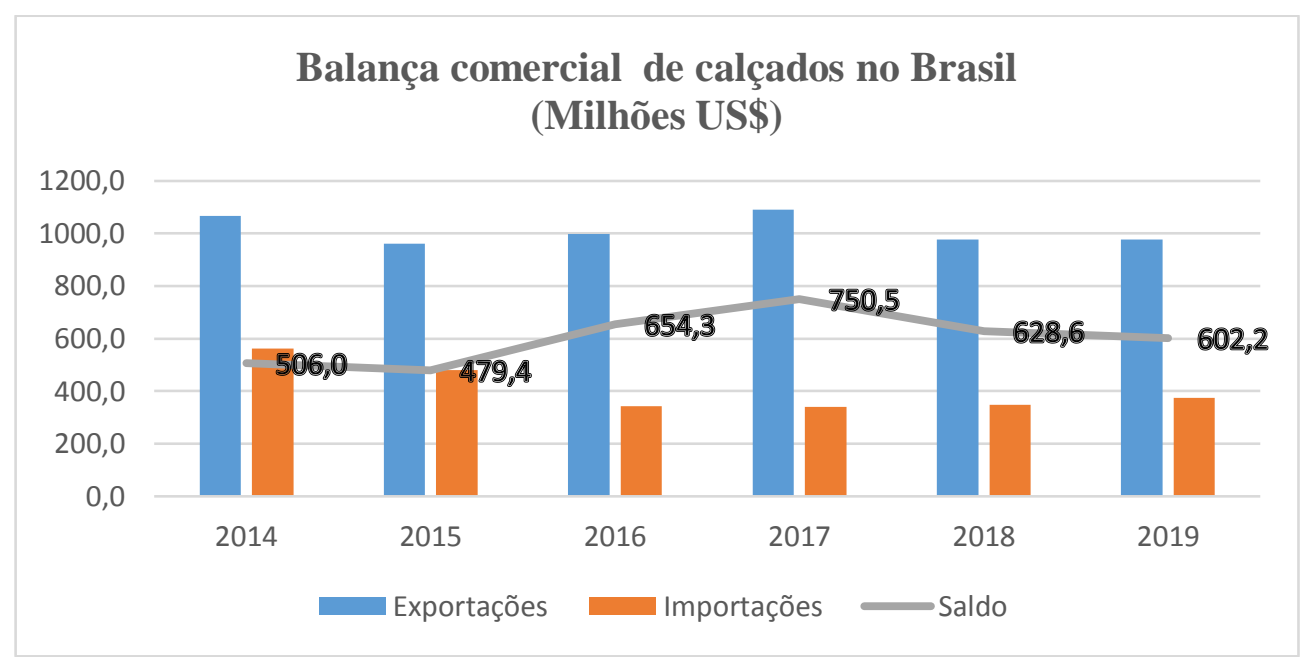

Fonte: Adaptado de (SECEX apud ABICALÇADOS, 2019, p.24; ABICALÇADOS, 2018)

Tabela 4 - Média da cotação do dólar americano para venda Brasil (2014-2018)

\begin{tabular}{|ccccccc|}
\hline \multicolumn{8}{c|}{ Média do valor do dólar US\$ nos últimos anos no Brasil } \\
\hline & $\mathbf{2 0 1 4}$ & $\mathbf{2 0 1 5}$ & $\mathbf{2 0 1 6}$ & $\mathbf{2 0 1 7}$ & $\mathbf{2 0 1 8}$ & $\mathbf{2 0 1 9}$ \\
US\$ & 2,16 & 2,35 & 3,33 & 3,49 & 3,19 & 3,65 \\
\hline \multicolumn{7}{c}{ Fonte: Adaptado (IEGV apud ACSP, 2020) }
\end{tabular}

Uma pesquisa feita com seis indústrias calçadistas consolidadas (entre 30-75 anos de tempo mercado), localizadas no Rio Grande do Sul, apresentou os motivos as quais elas buscam à exportação. Segue alguns desses motivos foram declarados e seguem exemplos dos resultados: saturação do mercado nacional, reconhecimento das marcas brasileiras em mercados globais, incentivo governamental em redução de taxas (produção no Nordeste), programa dos últimos 5 a 6 anos que subsidia companhias de calçados para irem em feiras internacionais e promover seus produtos. Uma indústria citou que aproveita a baixa temporada brasileira para produzir a encomenda internacional, principalmente após o período do natalino (entre 
dezembro e fevereiro). Por outro lado, apontaram também a falta de incentivo do governo na indústria manufatureira (CAMPOS et al., 2018).

Outro motivo que protege a indústria calçadista brasileira e contribui para a balança comercial com histórico positivo é a taxa de importação do par de calçado chinês. A taxação de importação foi renovada pelo setor, em 2016, da ação antidumping do produto acabado de calçado. Porém, mesmo diminuindo o valor de U\$13,85 para U\$10,22, válido por 5 anos, até março de 2021, continua sendo uma medida protecionista para a indústria nacional (ABICALÇADOS, 2016).

Por outro lado, mesmo com a ação protecionista contra a China, houve reação do mercado (SANTANA, 2015a) e, ao invés de importar o produto acabado, empresas passaram trazer, separadamente as partes e montá-lo no país. Assim, desde 2010, ano em que foi criada a taxação antidumping pela Câmara do Comércio Exterior, nº14 (CAMEX, 2010). Assim, pode ser observado nesse período um aumento das importações dos componentes separados (Figura 2).

Figura 2 - Comparação entre a importação brasileira de produtos chineses, calçados versus componentes de calçados (1997-2019) (Em milhões US\$)

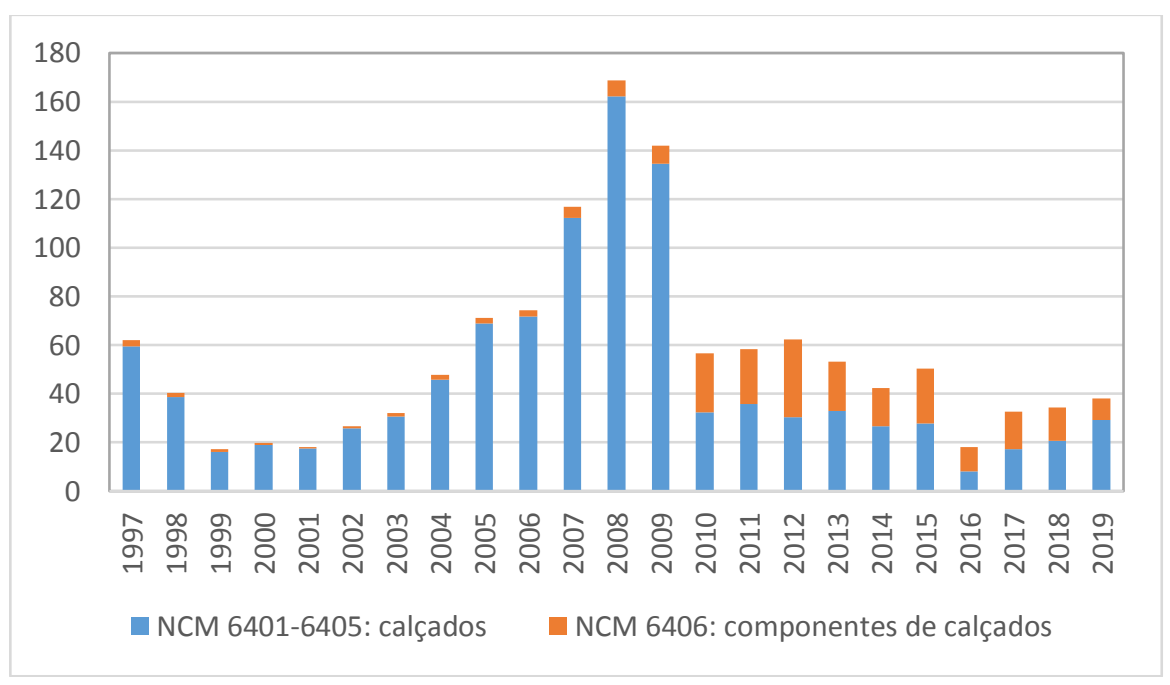

Fonte: (MDCI, 2020; SANTANA, 2015b)

Outros dados importantes para a economia do setor nacional é o perfil das empresas brasileiras calçadistas, estes dados são mostrados na Figura 3, sendo que quase a metade do total de 6,6 mil estabelecimentos em 2017 concentram-se em microempresas (até 19 trabalhadores) e correspondem a 78,2\% dentre os estabelecimentos do segmento e, com apenas $12,7 \%$ da concentração de emprego. A maior concentração de emprego é atribuída por reduzida 
quantidade de empresas de grande porte (mais de 500 funcionários) no país, representando 1,1\% do total de estabelecimentos (cerca de 70 indústrias), com 43,3\% dos empregos (Figura 3) (ABICALÇADOS, 2019).

Figura 3 - Concentração do emprego e das empresas calçadistas brasileiras, de acordo com o tamanho das empresas em número de trabalhadores (faixa de emprego)

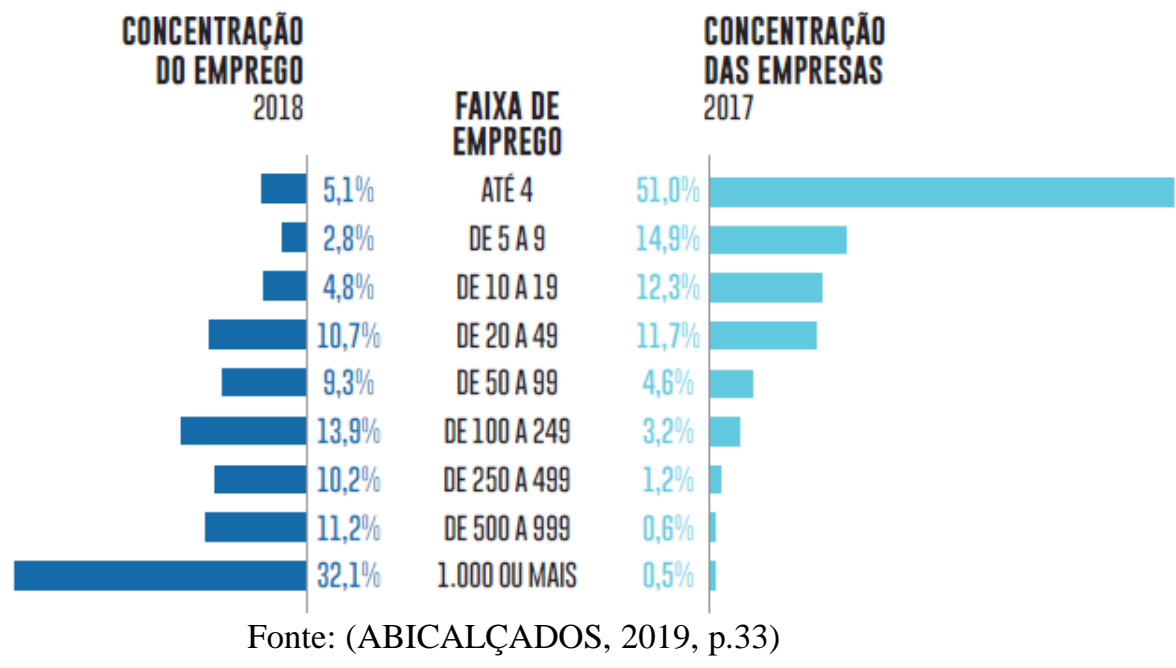

O setor há alguns anos está passando por uma crise, com forte retração em valores, na qual o Produto Interno Bruto (PIB) caiu em 2015 para -3,6\% e, em 2016 para $-4,06 \%$ (CARVALHO; SAMPAIO, 2019). Enquanto no mercado das indústrias calçadistas brasileira também registrou enfraquecimento do setor, tanto que entre os anos 2013 e 2014, ocorreu o fechamento de 18,6 mil postos de trabalho e, entre 2014 e 2015, mais 26,1 mil desempregados (Tabela 5) (ABICALÇADOS, 2017). Contudo, entre 2015 e 2016, houve uma recuperação de 1,9 mil empregos na indústria calçadista nacional, mas não aconteceu o mesmo em relação ao número de estabelecimentos (Tabela 6), pelo contrário, houve o fechamento de 638 indústrias. Infelizmente, o número de empregos formais e estabelecimentos voltaram a ter retração entre 2016-2018 (Tabela 5 e Tabela 6) (ABICALÇADOS, 2017, 2018, 2019). 
Tabela 5 -Emprego na indústria calçadista brasileira por Unidade da Federação (em mil postos de trabalho)

\begin{tabular}{|c|c|c|c|c|c|c|c|}
\hline Estado & 2013 & 2014 & 2015 & 2016 & 2017 & 2018 & $\begin{array}{c}\text { Variação } \\
\text { 2017-2018 }\end{array}$ \\
\hline Rio Grande do Sul & 108,3 & 101,8 & 95,1 & 95,5 & 92,6 & 87,9 & $-4,4 \%$ \\
\hline Ceará & 63,7 & 61,4 & 54,8 & 53,4 & 53,2 & 55,4 & $6,1 \%$ \\
\hline São Paulo & 54,2 & 49,9 & 42,4 & 39,7 & 38,6 & 34,3 & $-10,4 \%$ \\
\hline Minas Gerais & 33,2 & 32,6 & 28,7 & 31,2 & 31,0 & 30,4 & $-1,0 \%$ \\
\hline Bahia & 26,2 & 24,2 & 24,8 & 28,1 & 27,7 & 27,8 & $-0,3 \%$ \\
\hline Paraíba & não consta & não consta & não consta & 15,0 & 14,2 & 14,7 & $3,6 \%$ \\
\hline Santa Catarina & 7,8 & 7,2 & 6,8 & 6,6 & 6,9 & 6,6 & $-2,1 \%$ \\
\hline Outros & 34,5 & 32,1 & 30,5 & 15,5 & 14,7 & 14,0 & $-4,8 \%$ \\
\hline Total & 327,9 & 309,3 & 283,1 & 285,0 & 278,8 & 271,1 & $-2,0 \%$ \\
\hline
\end{tabular}

Tabela 6 - Quantidade de estabelecimentos de fabricação de calçados por Unidades da Federação

\begin{tabular}{lcccccc} 
Estado & $\mathbf{2 0 1 3}$ & $\mathbf{2 0 1 4}$ & $\mathbf{2 0 1 5}$ & $\mathbf{2 0 1 6}$ & $\mathbf{2 0 1 7}$ & $\begin{array}{c}\text { Variação } \\
\mathbf{2 0 1 6 - 2 0 1 7}\end{array}$ \\
\hline Rio Grande do Sul & 3.160 & 2.989 & 2720 & 2461 & 2234 & $-9,2 \%$ \\
Ceará & 2.667 & 2.565 & 2403 & 2225 & 2064 & $-7,2 \%$ \\
São Paulo & 1.316 & 1.307 & 1225 & 1131 & 1062 & $-6,1 \%$ \\
Minas Gerais & 332 & 331 & 306 & 295 & 262 & $-11,2 \%$ \\
Bahia & 310 & 311 & 278 & 240 & 243 & $1,3 \%$ \\
Paraíba & não consta & não consta & 110 & 121 & 114 & $-5,8 \%$ \\
Santa Catarina & 101 & 116 & 104 & 96 & 89 & $-7,3 \%$ \\
Outros & 785 & 767 & 607 & 546 & 503 & $-7,9 \%$ \\
\hline Total & $\mathbf{8 . 6 7 1}$ & $\mathbf{8 . 3 8 6}$ & $\mathbf{7 7 5 3}$ & $\mathbf{7 1 1 5}$ & $\mathbf{6 5 7 1}$ & $\mathbf{- 7 , 6 \%}$ \\
\hline \multicolumn{7}{c}{ Fonte: Adaptado em (RAIZ/TEM apud ABICALÇADOS, 2017, 2018, 2019) }
\end{tabular}

\subsubsection{Polos Regionais Brasileiros}

O complexo industrial de calçados do Brasil está organizado em polos, caracterizados como economias de aglomeração pela proximidade dos fornecedores de matérias-primas (CAVALHEIRO; BRANDAO, 2017; ROCHA et al., 2017; SUZIGAN et al., 2004). “Clusters representam uma natural manifestação de conhecimento especializado, habilidades, infraestrutura, e suporte às indústrias na melhoria da produtividade como chave determinante de sustentar altos níveis de prosperidade na localidade" (PORTER, 2003, apud CAVALHEIRO; BRANDAO, 2017, p.)

De acordo com a Figura 4, é importante destacar a concentração dos polos calçadistas, em que há algumas especificações regionais para se mapear essa distribuição. Assim, temos a região Nordeste com a maior produção em volume de pares (principalmente nos polos de 
Sobral-CE, Campina Grande-PB e Bahia), seguido pelas regiões Sul (Vale do Rio dos SinosRS, Vale do Paranha-RS, São João Batista-SC) e Sudeste (Nova Serra-MG, Birigui-SP, FrancaSP) (Figura 4) (ABICALÇADOS, 2018). A Figura 5 detalha a quantidade de polos em cada estado e sua distribuição (em porcentagem), mostrando que eles são bem desiguais entre si e que são localizados principalmente na costa leste brasileira, no sudeste, sul e nordeste.

Figura 4 - Porcentagem e quantidade (milhões de pares) calçados produzidos por estado e os principais polos de cada estado no Brasil

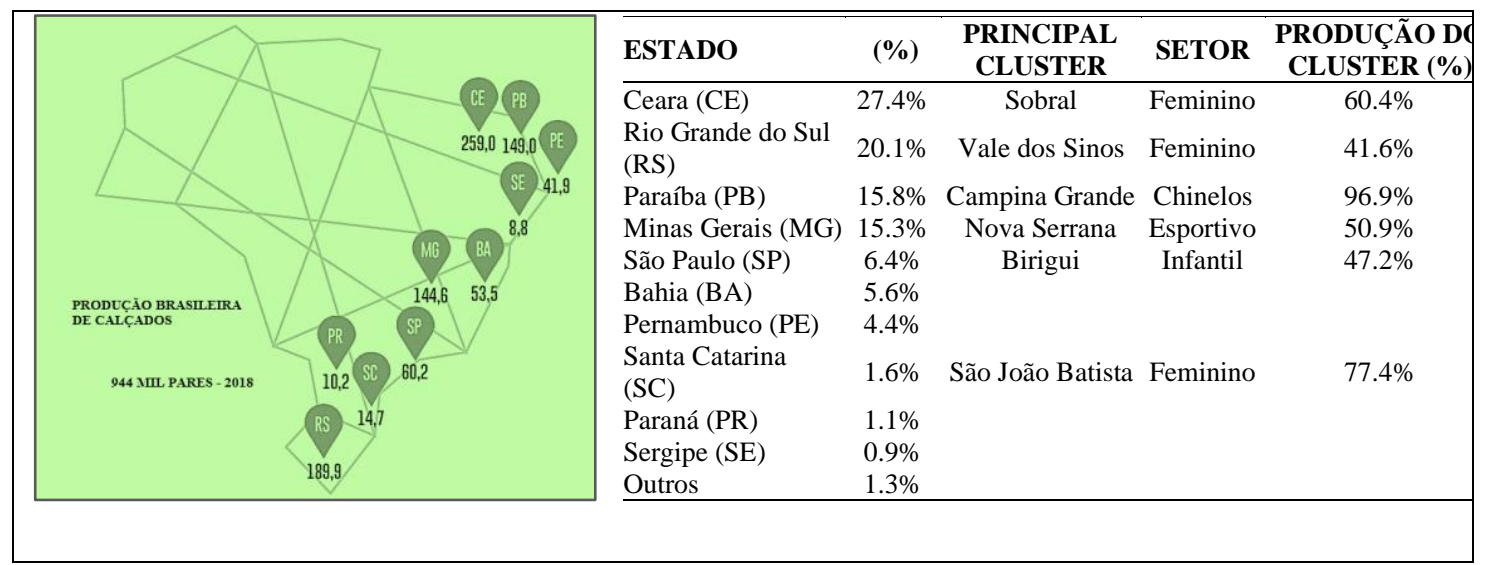

Fonte: Adaptado de (ABICALÇADOS, 2019, p.19)

Figura 5 - Concentração dos principais polos calçadistas nas unidades da federação do Brasil

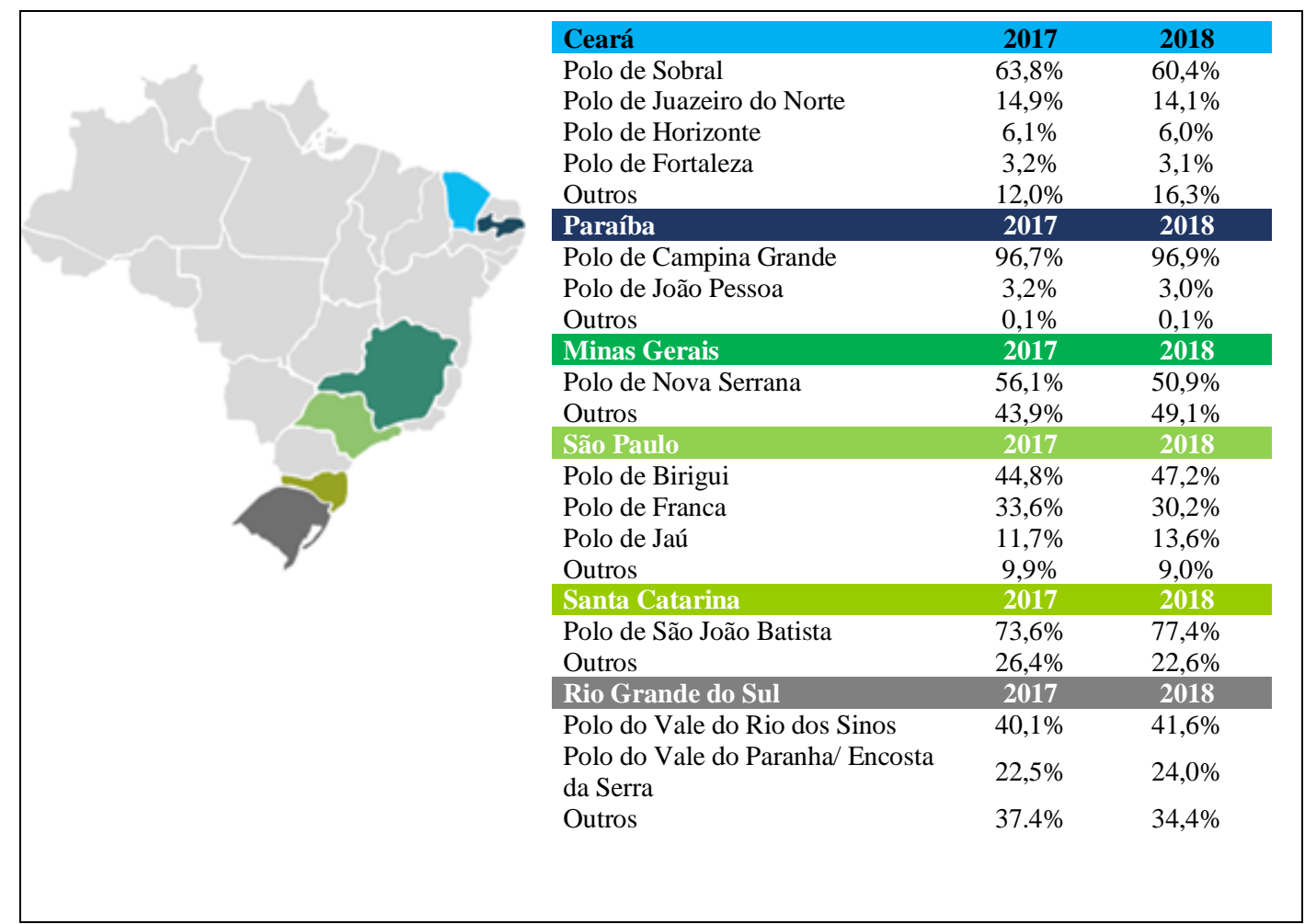


Dentro dos polos, atualmente, há um predomínio de tipo de calçado produzido, de acordo com o público alvo (SANTANA, 2015a), assim temos: em São Paulo, a cidade de Franca (masculino e mais recentemente bolsas), Birigui (infantil) e Jaú (feminino); no Rio Grande do Sul (feminino e, também, esportivo e infantil); em Minas Gerais, Nova Serrana (esportivos); no Ceará, as cidades de Cariri, Fortaleza e Sobral (feminino); na Bahia (diversos) e na Paraíba (sandálias).

Outra região de importante no país é o polo de Nova Serrana, no Estado de Minas Gerais (Figura 4), com a produção de 75,8 milhões de pares/ano (2017), corresponde ao $3^{\circ}$ polo mais produtivo (ABICALÇADOS, 2018). No mercado nacional, a indústria local é conhecida, pejorativamente, como "indústria da cópia” do tênis esportivo das marcas tradicionais. Porém, já há uma forte formalização do setor, como é descrito por (SANTOS, 2013), quando, em 2002, já perfaziam 55\% dos tênis produzidos no país. A região exporta menos de $5 \%$ e tem como mercados o próprio Estado e São Paulo (NAZARÉ; ROMEIRO FILHO, 2015).

É importante destacar as cidades do Estado de São Paulo devido à diversificação da produção, conforme Figura 5, a qual constitui a $5^{\text {a }}$ região mais produtiva no país. A cidade de Franca (SP) é considerada a capital dos calçados masculinos, com predominância em couro e com destaque na exportação, segundo os dados do Sindifranca (2012, apud CARMO, 2012, p.67); em 2010, a região produzia cerca de $85 \%$ de calçados de couro, em que $74,10 \%$ era do segmento masculino e 21,12\% feminino. Birigui (interior de São Paulo) é considerada a cidade maior produtora de calçados infantis do país, com cerca de $85 \%$ da produção do segmento, no ano de 2005 (SINBI, 2011). É importante destacar também o crescimento das empresas pequenas, as quais, em 1985, eram 11 empresas, passando para quase 180, em 2008 (CICERO, 2011).

Ressalta-se que as regiões Sul e Sudeste eram as maiores produtoras de calçados, até as décadas de 1980 e 1990, quando detinham cerca de 68\% da produção nacional, diante do Nordeste, que era pouco ocupado, quando detinha, em 1991, apenas 3,3\% dos empregos diretos formais no setor. Entretanto, em 2001, houve uma transformação, saltando a quantidade de empregos, na região, para mais de 20\% (CASTRO; MOREIRA, 2009b).

O aumento de empregos formais no Nordeste ocorreu pela mudança geográfica de empresas do Sul e Sudeste, em razão do oferecimento de vantagens salariais, fiscais e financeiras (CASTRO; MOREIRA, 2009b; SANTANA, 2015a). Essa realocação foi uma das consequências da ação brasileira diante do aumento dos calçados chineses, no mercado exportador mundial. Como decorrência, houve a baixa do preço médio, a partir de 1997, 
causada pela perda de competitividade do produto brasileiro e, para ter preços competitivos, uma das alternativas foi a substituição de materiais, como o uso do laminado sintético, ao invés do couro (SOUZA, 2003).

A transferência estratégica das regiões Sul e Sudeste para o Nordeste ocorreu, na maioria dos casos, apenas no setor fabril, permanecendo os setores de administração em suas matrizes, inclusive setores de desenvolvimento (SOUZA, 2003). A transferência do polo de Franca (SP) para o nordeste não foi maior, pois houve falta de mão-de-obra especializada; parte dos calçados produzidos nessa região necessitam de costureiros manuais, que prestam serviço e são fundamentais, principalmente, nos modelos de sapatos masculinos, chamados mocassins, que utilizam essa costura no acabamento (CARMO, 2012). Apesar disso, com o passar do tempo, foi aumentando a especialização da força de trabalho nas novas localidades.

O Estado do Rio Grande do Sul tem se destacado há muito tempo na indústria calçadista brasileira, como é mostrado na Figura 5, como o $2^{\circ}$ polo com maior produção - 186,9 milhões de pares/ano (2017) (ABICALÇADOS, 2018). A região sul, principalmente o Vale do Paranhana e no Vale dos Sinos fazem parte das principais produtoras e exportadoras de indústrias calçadistas do Estado, por produzir tanto calçados com maiores valores agregados e, ainda, conseguem desenvolver produtos de baixo custo com design e valor agregado (SANTANA, 2015a; SCHREIBER, 2015). Com isso, possui o maior índice de exportação do país em faturamento de 73,5 milhões com 43,7\% de participação em 2016 (ABICALÇADOS, 2018).

A Figura 6 mostra que o preço médio do calçado exportado brasileiro em todos os tipos de materiais (descritos no Anexo A- de acordo com a Nomenclatura Comum do Mercosul $\mathrm{NCM}^{1}$ - 6401 a 6405). Os dados foram mostrados a partir dos principais estados do país exportadores, que são: o Rio Grande do Sul, São Paulo, Ceará, Paraíba e média brasileira (19972013). Mostra-se um crescimento considerável nos anos 2000, após quedas em 2004, ocorrido devido à exportação para o mercado europeu, uma vez que os preços dos calçados vendidos para os EUA também subiram, apesar da quantidade também ter diminuído. Enquanto isso, para a América Latina não houve variação considerável (CAMPOS; CALANDRO, 2009).

\footnotetext{
${ }^{1}$ NCM é um que representa a classificação SH (Sistema Harmonizado de Designação e Codificação de Mercadorias) e especificações internas do Mercosul. Fonte: https://blog.sage.com.br/ncm-o-que-significa-e-quala-sua-importancia/
} 
Figura 6 - Preço médio do calçado exportação brasileiro

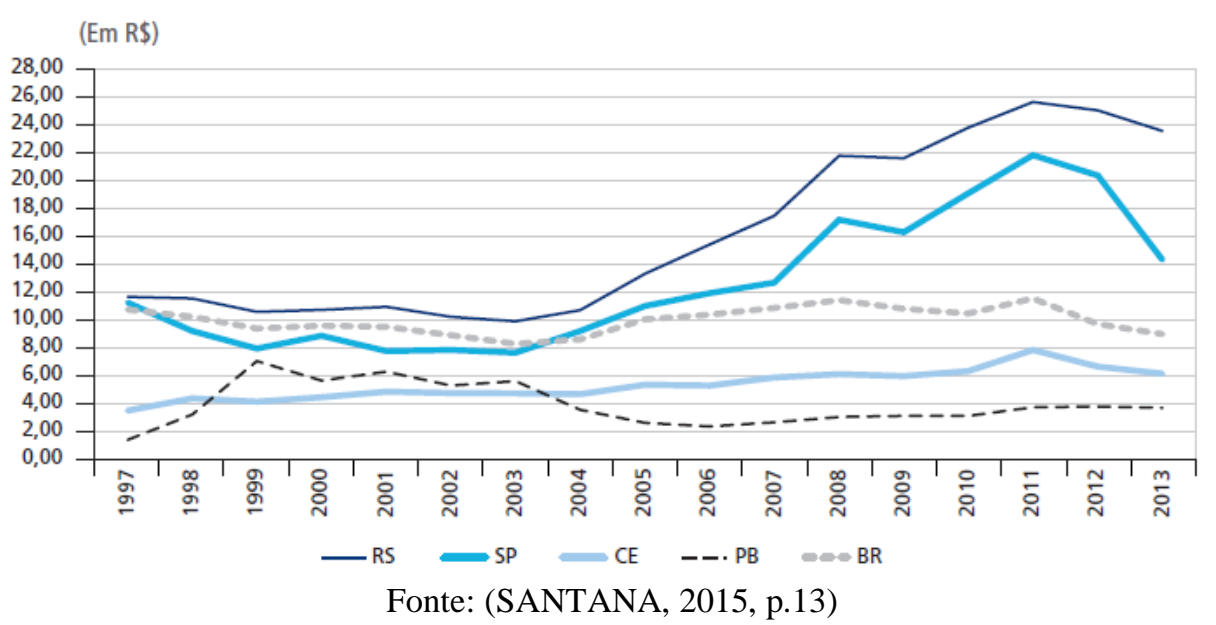

Dados mais recentes do preço médio do calçado brasileiro exportado são mostrados por estado, entre os períodos de 2016-2018 (Tabela 7). Esses dados são superiores em valores, quando comparados com os dos anos anteriores (Figura 6). Os valores em reais foram calculados de acordo com a Tabela 7, referente à cotação do dólar americano no mesmo período. Mesmo com valores maiores, ambas referências colocam o estado do Rio Grande do Sul com preço maior do par de calçado exportação do país, podendo ainda esse valor superior ser atribuído ao uso do couro como matéria prima (RODRIGUES; SALOMÃO, 2018), mesmo ele não sendo mais tão predominante entre as matérias primas do calçado brasileiro, como será apresentado mais adiante.

Tabela 7 - Preço médio do calçado brasileiro exportado (período entre os anos 2016-2018)

\begin{tabular}{lccc}
\hline \multicolumn{4}{c}{$\begin{array}{c}\text { Preço médio do calçado brasileiro exportado } \\
\text { (em reais, 2016-2018) }\end{array}$} \\
\hline Estados & $\mathbf{2 0 1 6}$ & $\mathbf{2 0 1 7}$ & $\mathbf{2 0 1 8}$ \\
Rio Grande do Sul & 30,42 & 32,43 & 33,40 \\
Ceará & 31,29 & 36,91 & 29,18 \\
São Paulo & 15,26 & 18,61 & 18,18 \\
Paraíba & 38,79 & 33,90 & 21,96 \\
Bahia & 16,54 & 22,12 & 17,79 \\
Outros & 22,31 & 35,03 & 26,84 \\
Preço médio & 26,46 & 30,80 & 27,43 \\
\hline
\end{tabular}

Fonte: Adaptado de (ABICALÇADOS, 2019; IGV apud ACSP, 2020) 
4.2.4. Histórico dos materiais empregados na indústria calçadista brasileira

Na fabricação de calçados, insumos da indústria química, naturais, couros e peles e da indústria têxtil são utilizados na manufatura de transformação para a confecção de componentes (Quadro 2) (GUIDOLIN; CRISTINA; ROCHA, 2010).

Quadro 2 - Cadeia de insumos da indústria calçadista

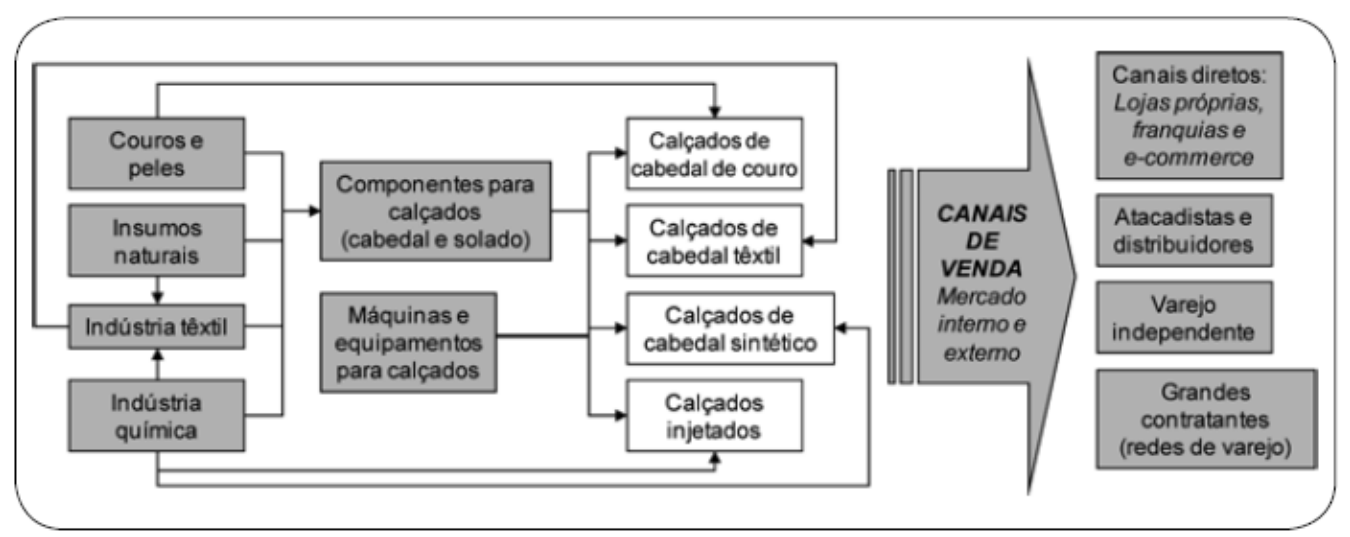

Fonte: (Adaptado CGEE, 2008 apud GUIDOLIN; CRISTINA; ROCHA, 2010)

A proporção dos tipos de materiais aplicados no calçado brasileiro em 2017 foi de: 49,8\% plástico/borracha, 25,2\% laminado sintético, 19,6\% couro, 4,2\% têxtil e 1,2\% outros (Tabela 8) (ABICALÇADOS, 2018). Essa classificação é feita de acordo com o predomínio de material empregado no cabedal, que é a parte superior do calçado.

Tabela 8 - Produção de calçados no Brasil por material predominante em pares (\%)

\begin{tabular}{lccc}
\hline Material & $\mathbf{2 0 1 5}$ & $\mathbf{2 0 1 6}$ & $\mathbf{2 0 1 7}$ \\
\hline Couro & $20,0 \%$ & $20.2 \%$ & $19,6 \%$ \\
Plástico/Borracha & $48,1 \%$ & $46,9 \%$ & $49,8 \%$ \\
Laminado Sintético & $27,3 \%$ & $27,8 \%$ & $25,2 \%$ \\
Têxtil & $4,0 \%$ & $4,3 \%$ & $4,2 \%$ \\
Outros & $0,6 \%$ & $0,9 \%$ & $1,2 \%$ \\
\hline
\end{tabular}

Fonte: (ABICALÇADOS, 2018, p.21)

Como falado anteriormente, a alta participação de plástico/borracha ocorre devido ao grande mercado de chinelos, principalmente do chinelo de dedos, modelo conhecido como flipflop (GUIDOLIN; CRISTINA; ROCHA, 2010).

Os laminados sintéticos ganharam força e houve um reposicionamento em vendas e valor nos últimos anos, pois antes eram associados a produtos de baixa qualidade (TEIXEIRA; 
ROMANO; ALVEZ-FILHO, 2014). Também outros componentes plásticos ganharam mercado no setor, a empresa Grendene focou em produtos licenciados e no desenvolvimento de plástico injetado em PVC e, por ser produtora de sua matéria-prima, investiu em novos modelos e, como consequência, patenteou diversos produtos. A mesma empresa também produz a sandália da marca Melissa ${ }^{\circledR}$ (Figura 7), ela é outro exemplo de calçado brasileiro, que reposicionou-se no mercado, aliado ao design, em um produto durável e que pode ser reusado (FERREIRA; SCARABOTO, 2016).

Figura 7 - Modelos de sandália da marca Melissa

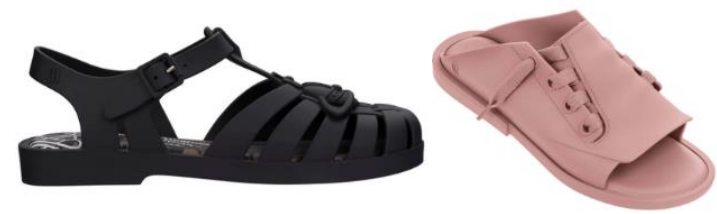

Fonte: (MELISSA, 2020)

Os tecidos, no Brasil, aplicados em calçados, seguem tendências de moda em estampas e padronagens, tendo estrutura de malha ou tecido (Figura 8 a e b), dependendo da aplicação, e cada tecelagem utiliza um segmento de matérias-primas (TEIXEIRA; ROMANO; ALVEZFILHO, 2014). Os tipos de tecidos mais comuns no segmento são: algodão (denim e lona), poliéster (forros microfilamentados em malha ou não, suede ou chamoix); além disso, há outros materiais têxteis para passamanaria, isto é, segmento têxtil que fabrica tecidos estreitos como cordões e trançado de juta, são utilizados para recobrimento de saltos (SANTOS; RAZZA; SANTOS, 2015).

Figura 8 -Ligamentos fundamentais de tecidos - a: tecido em tear, b: tecido em malharia, c: não tecido.

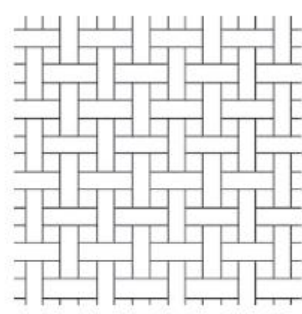

(a)

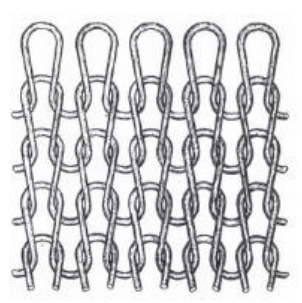

(b)

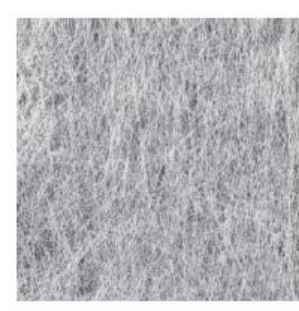

(c)

Fonte: (SONDHEL, 2000)

Além dos tecidos tradicionais, também se enquadra como têxtil, a estrutura em nãotecido (TNT), que é composto por fibras ou filamentos unidas em camadas por via 
mecânica, térmica ou química (Figura 8c) (INDA, [s.d.]). O dados nacionais da produção de nãotecidos apontam o emprego de $6 \%$ desse material têxtil em calçados, essa parcela representa, em relação à produção nacional, em torno de 613.976 toneladas/ano (2013), somadas à importação de 86.818 toneladas/ano (MARIANO, 2014)

Apesar de não ser mais tão expressivo a produção de calçados de couro brasileiro, em 2017, o mercado do couro bovino em pele tinha grande importância na exportação. No ano de 2013, o país era o segundo maior produtor e o terceiro exportador do mundo e, naquele ano, totalizou um recorde de valor exportado, de US\$ 2,511 bilhões, correspondendo a um crescimento de 20,8\% (em relação a 2012) (CICB, 2014). Desde lá, há uma tendência de queda; em 2017, o valor foi para US\$1,899 bilhões e, em 2018, US\$ 1,442 bilhões (CICB, 2018).

A exportação brasileira de couro em pele bovina (2018) totalizou 143,1 milhões de $\mathrm{m}^{2}$ e é dividida pelos 3 tipos de processamento do couro: wet blue, crust e acabado (vide item 5.4.1); tais tipos seguem em ordem crescente do processo produtivo do curtimento do couro (Quadro 2) e é representado na Figura 9 (CICB, 2018). Um destaque no segmento foi o aumento da exportação do couro acabado, nos últimos anos, pois, em 2000, 57\% do produto exportado era wet blue, enquanto, em 2018, reduziu para 43,8\%; assim, o aumento no uso de couro com maior processamento corresponde ao uso de um produto com maior valor agregado (CICB, 2014). Mesmo o país tendo couro acabado produzido internamente, houve a importação de 2,27 milhões de $\mathrm{m}^{2}$ (2018), com valor de US\$ 36,97 milhões.

Figura 9 - Exportações brasileiras por tipo de couro bovino (2018, \% área- $\mathrm{m}^{2}$ )

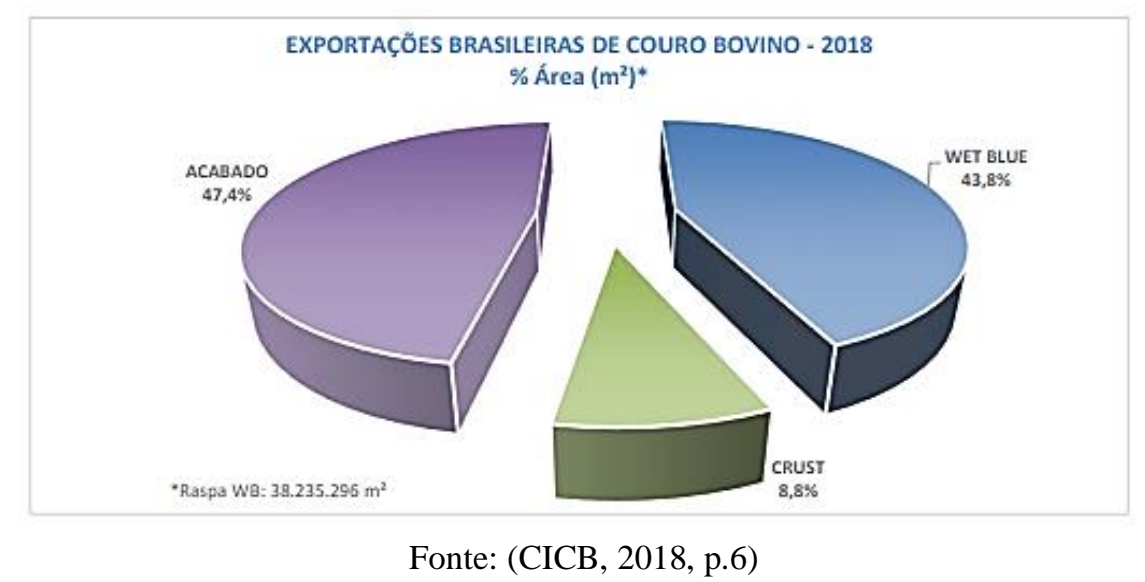

Houve também mudanças, nas últimas décadas, nos materiais dos calçados brasileiros, como já falado anteriormente, devido à concorrência chinesa, que obrigou o país a reduzir o preço final do calçado de exportação e, consequentemente, houve a substituição de matérias- 
primas. A Figura 10 é exemplifica esta inversão dos materiais aplicados nos calçados exportados, em 2003, quando havia o predomínio do couro natural no cabedal (63\%) e com apenas 26\% em cabedal sintético; enquanto, em 2011, 73\% dos produtos exportados eram de calçado sintético e, 22\%, de couro. Já em 2019, mostra-se essa tendência de redução do uso do couro ainda, mas há uma transferência de parte da produção divindade em materiais têxteis e sintéticos (ABICALÇADOS, 2019; ZINGANO; OLIVEIRA, 2014).

Figura 10 - Tipo de matéria prima dominante na exportação de calçados brasileiros (entre 2003-2011-2019)
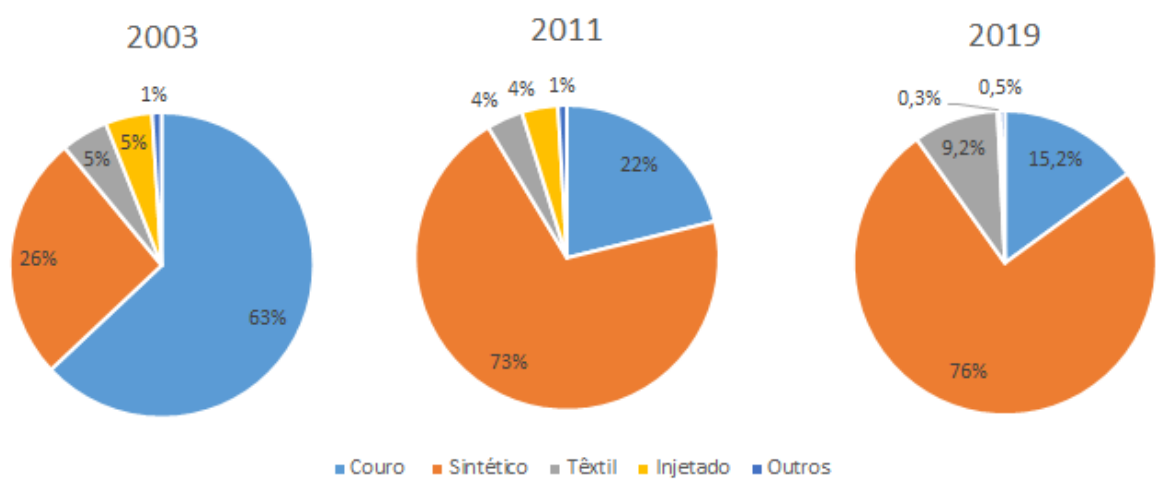

Fonte: (MDIC/Secex, 2012 apud ZINGANO; OLIVEIRA, 2014, p.301; ABICALÇADOS, 2019)

No mercado nacional, os componentes do calçado também seguem a tendência de predomínio de uso de materiais de fontes de petróleo. Isto pode ser verificado nas Tabelas 9, 10 e 11 que detalham a matéria prima dos principais componentes do calçado, no cabedal (parte superior), solado (parte inferior) e forro (parte interna) (GUIMAR ÃES, 2014).

Tabela 9 - Evolução dos materiais do cabedal nos calçados brasileiros (2016-2018)

\begin{tabular}{|c|c|c|c|c|c|c|}
\hline & Tipo de material & Ano & Couro & $\begin{array}{c}\text { Laminado } \\
\text { de PVC }\end{array}$ & $\begin{array}{c}\text { Laminado } \\
\text { de PU }\end{array}$ & Têxteis \\
\hline \multirow{3}{*}{ Cabedal } & & 2016 & $28 \%$ & $15 \%$ & $38 \%$ & $20 \%$ \\
\hline & & 2017 & $25 \%$ & $10 \%$ & $42 \%$ & $22 \%$ \\
\hline & & 2108 & $23 \%$ & $12 \%$ & $40 \%$ & $25 \%$ \\
\hline
\end{tabular}


Tabela 10 - Evolução dos materiais do solado nos calçados brasileiros (2016-2018)

\begin{tabular}{lcccccccccc}
\hline & $\begin{array}{c}\text { Tipo de } \\
\text { material }\end{array}$ & Ano & PVC & TR & PU & TPU & Borracha & EVA & Couro & Outros \\
\hline \multirow{3}{*}{ Solado } & 2016 & $16 \%$ & $47 \%$ & $14 \%$ & $3 \%$ & $11 \%$ & $2 \%$ & $2 \%$ & $5 \%$ \\
& 2017 & $19 \%$ & $41 \%$ & $16 \%$ & $3 \%$ & $14 \%$ & $2 \%$ & $1 \%$ & $4 \%$ \\
& & 2108 & $28 \%$ & $35 \%$ & $17 \%$ & $4 \%$ & $9 \%$ & $6 \%$ & $1 \%$ & $1 \%$ \\
\hline
\end{tabular}

Fonte: Adaptado de (GUIMARÃES, 2018)

Tabela 11 - Evolução dos materiais do forro nos calçados brasileiros (2016-2018)

\begin{tabular}{|c|c|c|c|c|c|c|c|c|}
\hline & Tipo de material & Ano & Couro & $\begin{array}{c}\text { Laminado } \\
\text { de PVC }\end{array}$ & $\begin{array}{c}\text { Laminado } \\
\text { de PU }\end{array}$ & Têxteis & Outros & $\begin{array}{l}\text { Não } \\
\text { Usa }\end{array}$ \\
\hline \multirow{3}{*}{ Forro } & & 2016 & $6 \%$ & $6 \%$ & $43 \%$ & $43 \%$ & $2 \%$ & $0 \%$ \\
\hline & & 2017 & $5 \%$ & $5 \%$ & $40 \%$ & $49 \%$ & $0 \%$ & $1 \%$ \\
\hline & & 2108 & $4 \%$ & $7 \%$ & $38 \%$ & $48 \%$ & $1 \%$ & $1 \%$ \\
\hline
\end{tabular}

Entre 2016 e 2018, o cabedal de poliuretano (PU) liderou como matéria de aplicação do mercado de calçados nacional, seguido de couro e têxteis, em que o couro tem uma tendência de queda, enquanto os têxteis estão em ascensão (Tabela 9). Nos materiais de solado, dentre diversos polímeros apresentados na Tabela 10, o policloreto de vinila (PVC) tem aumentado seu uso nos últimos anos, enquanto a borracha termoplástica (TR) reduzido. Nos forros (Tabela 11), há um predomínio de materiais têxteis, seguido de laminado em PU (GUIMARÃES, 2018).

Com isso, pode ser visto neste item que houve uma mudança muito grande nos materiais aplicados nos calçados brasileiros, principalmente na substituição do couro desde o início dos anos 2000. Polímeros sintéticos passaram a dominar a matéria prima dos calçados brasileiros, com destaque aos laminados de PU no cabedal, têxteis (sem identificarem tipos) e laminado de PU no forro e uma grande variedade deles são usados no solado.

\subsection{Componentes de Calçados}

Um calçado feminino é constituído pelas seguintes partes principais: enfeite e cabedal, forro, solado e adesivos (Figura 11) (ASSINTECAL, 2018). O solado ainda é subdividido em três itens: palmilha, contraforte e solado externo (RONCOLETTA, 2014). Apesar desses componentes que formam o calçado, há modelos que apresentam quase uma única parte, como pode ser visto na Figura 11 abaixo no chinelo de dedos e na sandália plástica. 
Figura 11 - Composição principal de um calçado feminino

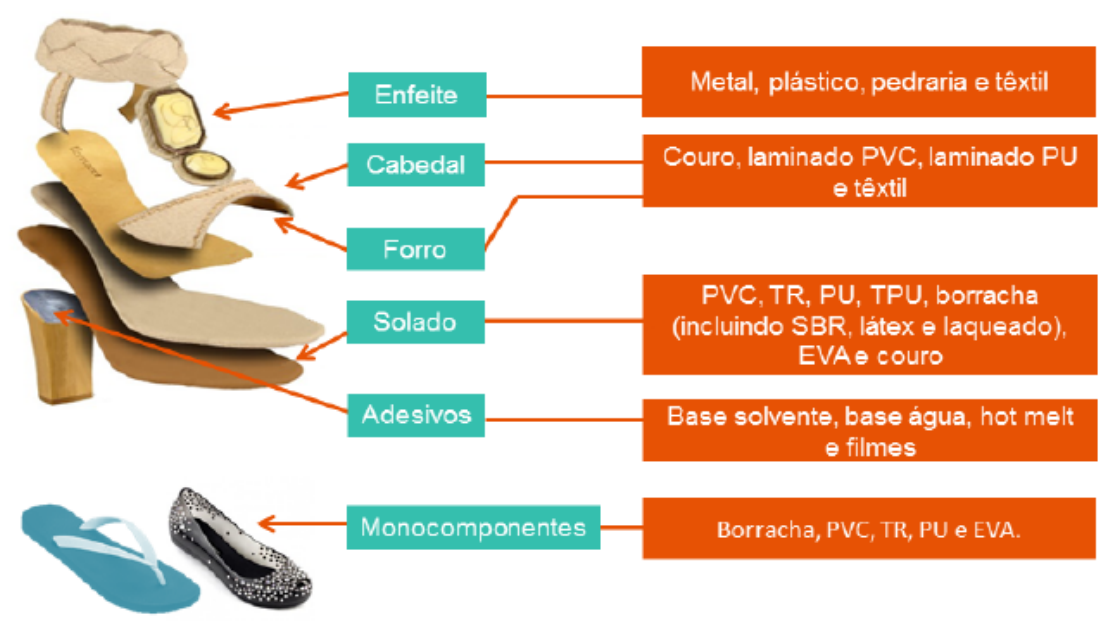

Fonte: (ASSINTECAL, 2018)

Diferentes modelos de calçados, podem implicar ampliação da variedade de componentes, assim, na Figura 12, foram melhor detalhados, ao se comparar com a Figura 11. A seguir será explorado cada parte separadamente, de acordo com a matéria prima e suas características, assim como, com a função que exerce no calçado, apresentando exemplos de alguns modelos.

Figura 12 - Descrição de todos os componentes de um calçado de salto feminino
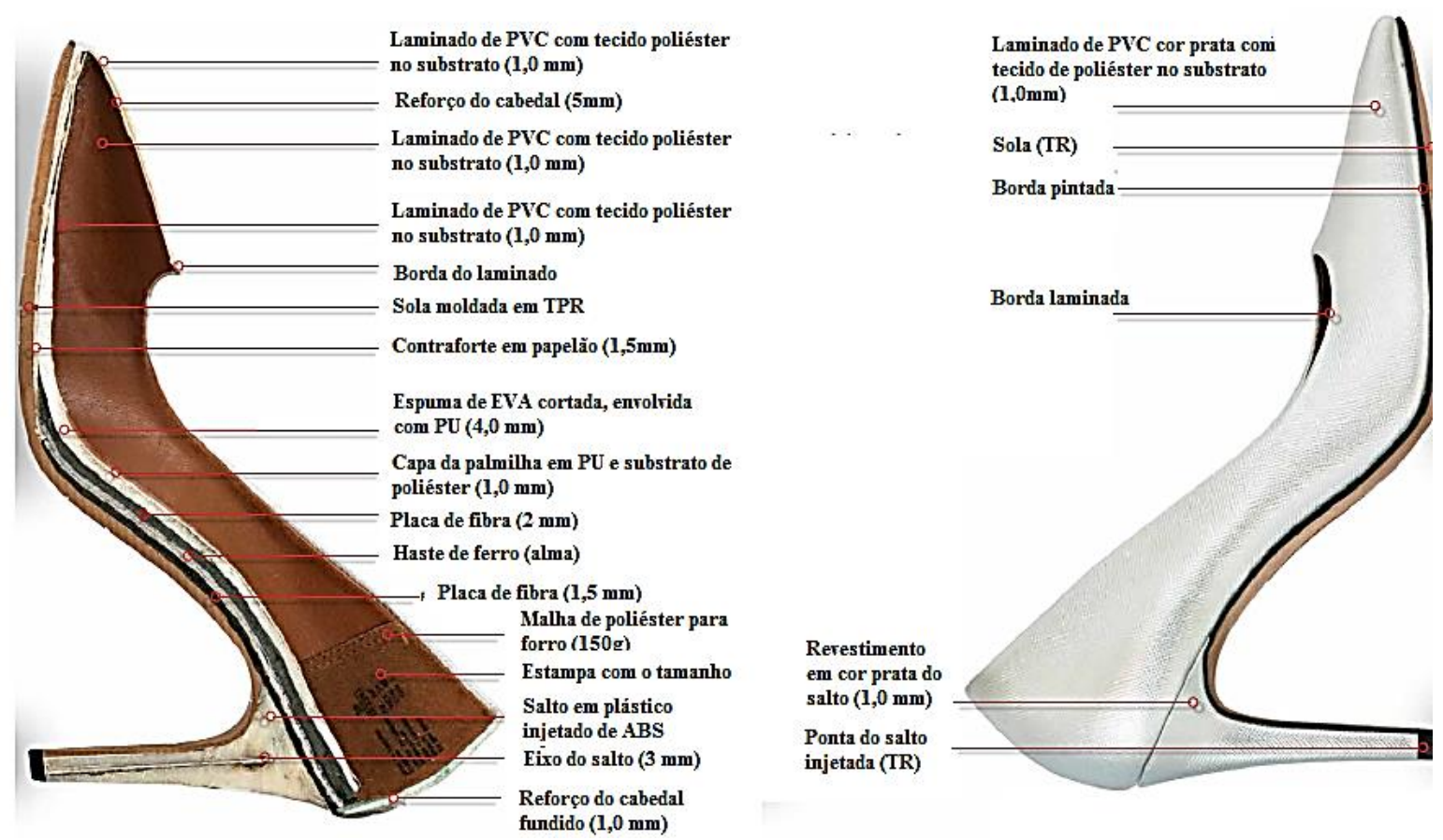

Fonte: Adaptado (MOTAWI, 2018, p.187) 


\subsubsection{Gáspea ou cabedal}

A gáspea ou cabedal tem a função em proteger e cobrir a parte superior do pé, mas também pode ser decorativa, como mostrado na Figura 13, em que o material tem uma cor rósea e uma textura imitando pele animal (COSTA, 2013). Em geral, os materiais mais comuns aplicados nos cabedais são: couro bovino ou outros animais (caprino, cobra, etc.); têxteis sintéticos (poliamida, poliéster, polipropileno, elastano, etc.) ou fibras naturais (algodão, juta, linho, etc.) em construções de tecidos, malha ou não tecido; laminado sintéticos (poliuretano, policloreto de vinila, etc.) (MOTAWI, 2018).

Figura 13 - Calçado com gáspea decorada (gravação animal e enfeite de metal) em modelo feminino mule

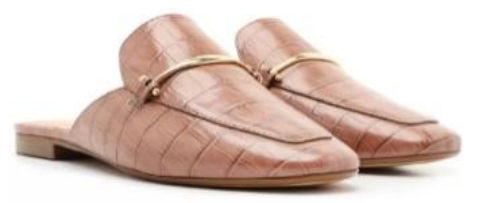

Fonte: (AREZZO, 2020a)

Do ponto de vista da construção do cabedal, há regras para sua confecção, e alguns pontos precisam ser considerados, como comprimento, largura e abertura. As aberturas são necessárias para auxiliar o consumidor a vestir os sapatos através dos zíperes, fivelas, ilhoses, cadarços e língua. A língua também auxilia numa proteção extra para a parte superior do pé, devido ao seu acolchoamento em espuma (NEBO, 2005; SUBOTNICK et al., 2010). No caso do calçado de corrida, a gáspea é determinante para deixar o modelo de tênis mais baixo com adequado ajuste aos pés e, como consequência, o modelo pode ajudar o corredor adquirir velocidade (NEBO, 2005).

Normalmente, a gáspea é formada por mais de uma peça e pode ser feita com materiais diferentes unidos por costuras. Além de dar a forma do sapato, os recortes possibilitam misturar cores, texturas, materiais e diferentes modelagens (Figura 14 e 15), além de seguir o padrão de moda vigente (PELIZZARI, 2013). 
Figura 14 - Recortes de um cabedal unidos por costura em couro e com diferentes cores.

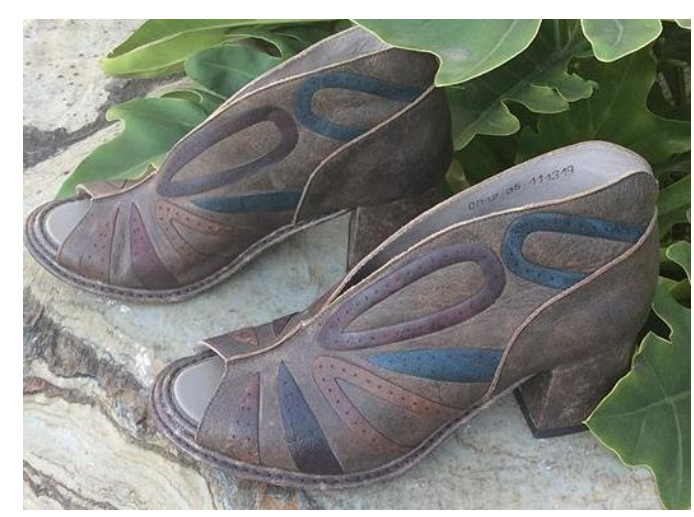

Fonte: (CALÇADOS, 2019)

Figura 15 - Partes de uma gáspea de um tênis em tecido e couro

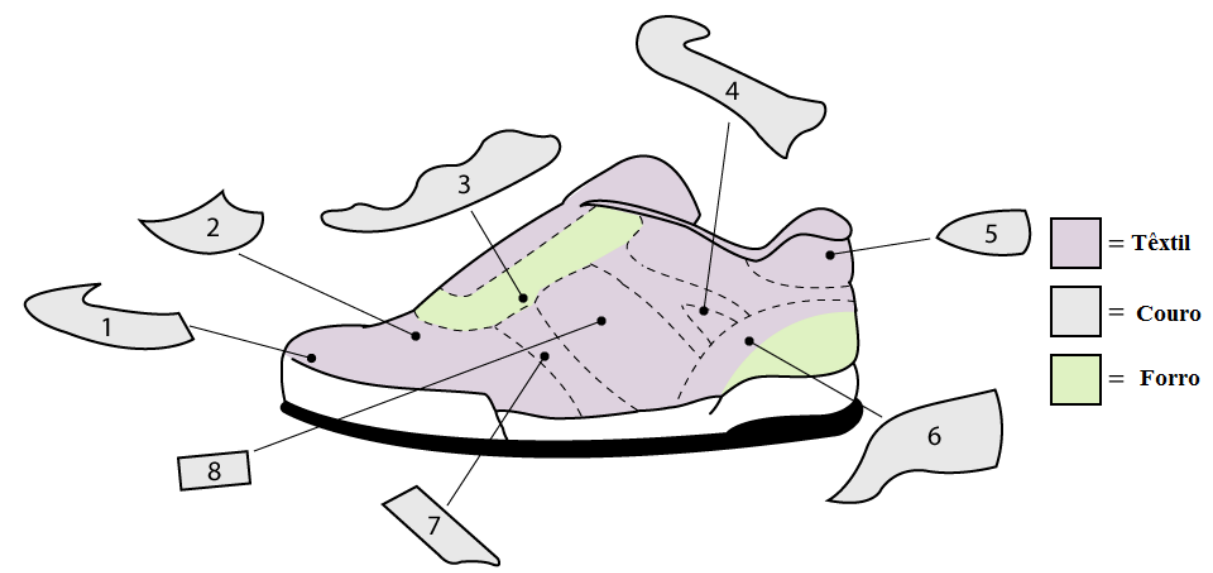

Fonte: Adaptado de (HM REVENUE \& CUSTOMS, 2015)

A modelagem da gáspea não adequada pode causar problemas ao pressionar os dedos e ossos do pé, assim, o que se pretende no calçado é ter um ajuste ao pé, mas sem causar dores (MELVIN et al., 2019; WILLIAMS, 2007). Há modelos de sapatos que utilizam um reforço, que serve como uma "caixa de proteção", além de forro, para evitar esse incomodo ao pé (SUBOTNICK et al., 2010; WILLIAMS, 2007).

O material escolhido para a gáspea influencia no microclima no interior do calçado, pois há a variação das propriedades em capacidade de dissipação de calor e umidade, vindos da superfície da pele (YICK; YU; LI, 2019).

Com a intensificação do uso de tênis no cotidiano das pessoas, nos momentos de lazer ou no trabalho, dependendo da profissão, houve uma diferenciação desses tênis comuns comparados aos modelos para prática de esporte. Em geral, tênis comuns tendem a ser um 
pouco mais pesados que os modelos de corrida e com melhor durabilidade (Figura 16) (WHITE, 2010).

Figura 16 - Tênis esportivo da marca Adidas ${ }^{\circledR}$ em cabedal com tecido acolchoado (mesh) e forrado

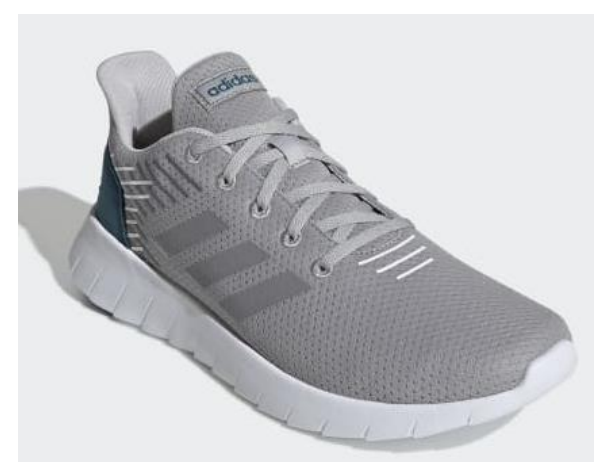

Fonte: (ADIDAS, 2020)

As duas maiores marcas do mundo no segmento esportivo são Nike e Adidas, ambas são importantes na customização em massa (desde 1990). Uma das definições de customização em massa é o processo produtivo, que utiliza etapas flexíveis na estrutura da organização para desenvolver produtos ou serviços customizados e com padrão de preço de massa (HART, 1995). Ou seja, cresceu a diversificação e ampliaram-se os tipos de modelos, de acordo com coleções, com variação de finalidades em tipos de esportes diferentes ou público alvo por gênero ou idade, como exemplos, tecnologias em amortecimento, tênis casuais, etc. (GRACIA; WINKELHEUS, 2016).

Houve mudanças no conceito de design e materiais dos cabedais para corrida, em busca de torná-los mais leves, assim como, reduzir o acolchoamento, ao se alterar a escolha do tecido. Além disso, outras características de um tênis para essa finalidade são requiridas, com a necesssidade da capacidade em flexão e boa absorção de choque, para permitir que os pés e corpo garantam impulsão e suporte durante a corrida (NEBO, 2005). Eles também se tornaram laváveis e mais arejados (SUBOTNICK et al., 2010).

A utilização da tecnologia de malharia 4D (quatro dimensões: têxteis em 3D nos quais a quarta dimensão corresponde à durabilidade) é um exemplo da evolução dos cabedais esportivos e rapidamente se expandiu, entre as principais marcas já citadas de tênis, e por outras também (Figura 17). Assim, o cabedal é produzido em apenas uma peça, no qual já são embutidos a língua, reforços e forro (Figura 18) (MOTAWI, 2018). No exemplo abaixo, pode ser visto como é o cabedal aberto, antes da montagem do calçado. De acordo com o autor, este 
cabedal foi feito por uma máquina, que utiliza fios de poliéster, náilon (poliamida 6.6) ou Spandex $^{\circledR}$ (ou elastano), com a escolha de mais de 10 cores juntas e com possibilidade de variação no título (peso/metragem padrão) e outras características do fio. Neste caso, o desenho pode variar em fibras, cores, título de fios e aberturas (padronagem da malha) (MOTAWI, 2018).

Figura 17 - Cabedal Flyknit modelo React Phantom Run da marca Nike sem forro

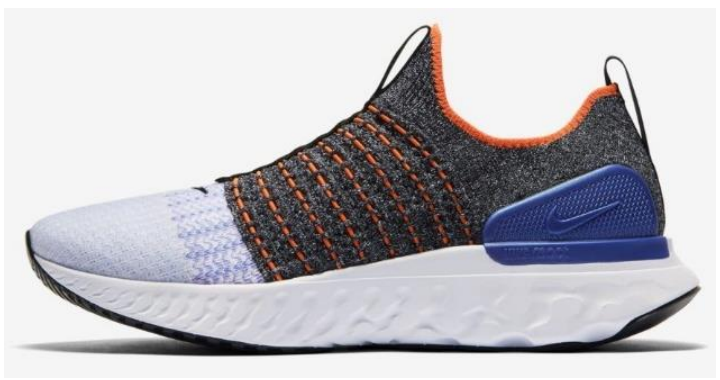

Fonte: (NIKE, 2020)

Figura 18 - Gáspea em malha 4D para tênis esportivo em múltiplos desenhos e cores

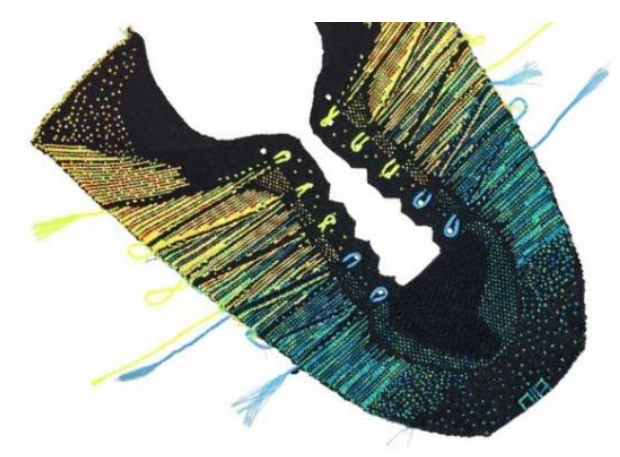

Fonte: (MOTAWI, 2018, p.20)

\subsubsection{Forro}

Como a interação entre o calçado e o pé do usuário ocorre através dos forros, é necessário escolher adequadamente seus materiais para assegurar as características de conforto requeridas (BLAGA et al., 2015; JANKAUSKAITÉ et al., 2018). O forro protege a parte dorsal do pé de partes como costuras ou outras regiões rígidas como contrafortes (calcanhar) (BLAGA; MARMARALI; MIHAI, 2011). 
O forro é determinante na durabilidade do calçado, pois contribui na redução do rasgamento do cabedal, por suportar parte da tensão e do movimento repetitivo da flexão do pé durante a caminhada. Também previne a distorção do cabedal e assegura a estabilidade, ajudando a manter o produto com boa aparência estética (BLAGA; MARMARALI; MIHAI, 2011).

No calçado esportivo, o material do forro normalmente é feito de tecido plano em nylon ou estruturas em malha simples ou atoalhada, todos têm toque macio, semiflexíveis e resistentes. É grande o controle da qualidade nestes tipos de calçado, principalmente em testes laboratoriais que conferem o atrito ou o chamado pilling, ao simular o desgaste mais intenso, que ocorre na região do colarinho do calçado e no calcanhar (NEBO, 2005).

O microclima em condição normal da fisiologia do pé apresenta a temperatura interna do calçado variando entre $22-33^{\circ} \mathrm{C}$, entre $60-80 \%$ de umidade relativa e cerca de $0,8 \% \mathrm{CO}_{2}$ (BLAGA et al., 2015).

Além do emprego nos calçados esportivos, têxteis no forro também são utilizados para outros modelos de sapatos, pois normalmente apresentam adequadas propriedades de higiene, pois o material precisa ter inúmeras qualidades: boa capacidade de absorção, boa permeabilidade de ar e água (NEBO, 2005); boa resistência à fricção quando úmido ou seco; boa resistência à tensão e deformação; boa resistência à perspiração; alta resistência térmica, quando ele é usado em locais frios; e boa resistência à cor (BLAGA; MARMARALI; MIHAI, 2011).

Apesar das empresas calçadistas utilizarem com mais frequência tecidos em fibras de poliéster e poliamida, nos forros, pesquisadores testaram fibras naturais (algodão), misturadas com fibras regeneradas (Liocel ${ }^{\circledR}$ e viscose normal ou de bambu - todas com celulose como matéria prima) em estruturas têxteis acolchoadas ou mesh e malha interlock e, que dissipam melhor o calor e umidade e, assim, obtendo-se soluções em conforto ao usuário, pelo fato que tais fibras absorvem a umidade e não deixam os pés suados. Mostrou-se eficiente principalmente as misturas em algodão/viscose de bambu e algodão/viscose comum (BLAGA et al., 2015).

Além disso, os laminados sintéticos, que são têxteis com fino recobrimento de polímeros, também são utilizados na forração de diversos modelos de sapatos em PVC e PU. Em geral, os matérias com poliuretano têm maior capacidade em permeabilidade ao ar em 
relação aos feitos em PVC, mas dependem da estrutura e tipo de matérias primas utilizadas para potencializar a ação em absorção e dessorção de água (GULBINIENE et al., 2007).

\subsubsection{Contraforte}

O contraforte é um componente reforçado, pois tem o objetivo de estabilizar o retropé ao envolver o calcanhar (Figura 19) (COSTA, 2013; WILLIAMS, 2007). Normalmente, quanto mais rígido ele for, influenciará na redução do deslizamento do pé durante a caminhada. Consequentemente, ele é fundamental, visando a redução das quedas. Porém, ainda não há uma regra geral de quando usar um contraforte mais rígido e qual o nível de rigidez ideal (BRANTHWAITE; CHOCKALINGAM, 2019).

Figura 19 - Localização da aplicação do contraforte no calçado

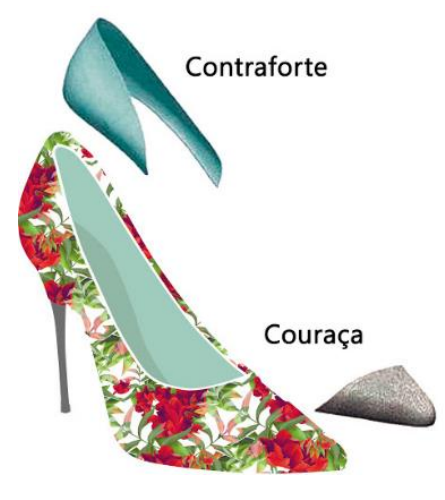

Fonte: (ENTRETEX, 2015)

Além disso, o contraforte auxilia na forma e modelo do calçado e com sustenta o calce. (ANDRADE; CORRÊA, 2001). No conforto, este componente influencia ainda mais para pessoas com deficiências, como pronação no pé ou pé plano, pois permite a fixação e estabilização do pé dentro do calçado (WILLIAMS, 2007). No calçado esportivo, adiciona-se um material acolchoado no interior, entre o contraforte e o cabedal, além do colarinho com espuma, afim de prover mais estabilidade e conforto (SUBOTNICK et al., 2010).

\subsubsection{Couraça ou Biqueira}

A couraça é um reforço colocado no bico do calçado, entre o cabedal e o forro, com função de dar forma e definir a altura da parte da frente (Figura 19). Normalmente é produzido com material termoplástico semirrígido (COSTA, 2013). Mesmo assim, o tradicional couro 
bovino também é adequado, por ter os atributos em flexão e moldagem, que fazem com que o material acomode de acordo com o formato do pé (SMITH et al., 2013).

O formato e o volume do ajuste da biqueira são muito importantes porque, quando um sapato está apertado, pode causar dor, ou até machucados e calos, ou ainda, em casos mais atenuantes, afetar a distribuição plantar (BRANTHWAITE; CHOCKALINGAM; GREENHALGH, 2013). Para exemplificar como as indústrias poderiam resolver parte dessas dimensões do calçado para dar conforto, houve uma pesquisa para desenvolver um calçado escolar ideal, para crianças do sul da Espanha. O estudo realizou mais de 500 medidas dos pés de crianças (entre 3-12 anos) e apontou que um calçado bem ajustado e confortável deveria ter a distância da biqueira e o dedo mais longo entre 5-15mm (GONZÁLEZ ELENA; CÓRDOBAFERNÁNDEZ, 2019).

Em aplicação mais específica, em calçados de segurança, a biqueira é fundamental para prevenção individual de acidentes. Os requisitos dependem da estrutura que deve ser rígida e resistente à deformação. Por ser um elemento pesado, pois normalmente é feito de ferro, diversas pesquisas estão testando novos materiais, sendo compósitos metálicos e poliméricos afim de deixá-los mais leves, podendo atingir cerca de 30\% a menos de suas massas (COSTA; MENDONÇA; PEIXINHO, 2016; PEIXINHO; COSTA; MENDONÇA, 2018).

\subsubsection{Parte inferior}

A parte inferior do calçado também influencia no conforto e ainda depende de diversos fatores como: ajuste ao pé, temperatura e umidade, distribuição plantar e força de impacto do solo. As forças de impacto, vindas do solo, são fatores que mais contribuem para o desconforto e isto ainda pode causar dor ou doenças, que são influenciadas pela construção de todos componentes da sola (SILVA et al., 2009; YICK, 2013).

A escolha do tipo do solado irá depender da função do calçado à qual ele é destinado e pode variar em peso, rigidez, espessura e suporte. Assim, devem ser observadas as características do solado em diversas condições climáticas ou em solos diferentes (molhados ou secos, na neve, grama, concreto etc.) para ser definida a durabilidade do sapato. Também todas as características especiais voltadas aos esportes, em que cada tipo de prática necessita de uma especificação em minimizar ou maximizar os movimentos, que devem ser levadas em consideração para o projeto (NEBO, 2005). 
Em geral, a estrutura de um solado é considerada em três principais: a palmilha, a entressola e a sola. A parte superior, a chamada palmilha, tem contato direto com o pé e necessita do ajuste correto à ele a ao modelo do calçado, e auxilia no conforto do usuário; a segunda faz parte do corpo principal, a entressola provém a estrutura e os parâmetros estéticos para o tênis esportivo; e a terceira é o "piso inferior", a sola tem o contato direto com o solo e deve impedir o escorregamento, atendendo às normas internacionais de segurança (Figura 20) (DAVIA-ARACIL; JIMENO-MORENILLA; SALAS, 2016). Estas partes serão detalhadas a seguir.

Figura 20 - Parte inferior do calçado (palmilha, entressola e solado) e outros componentes

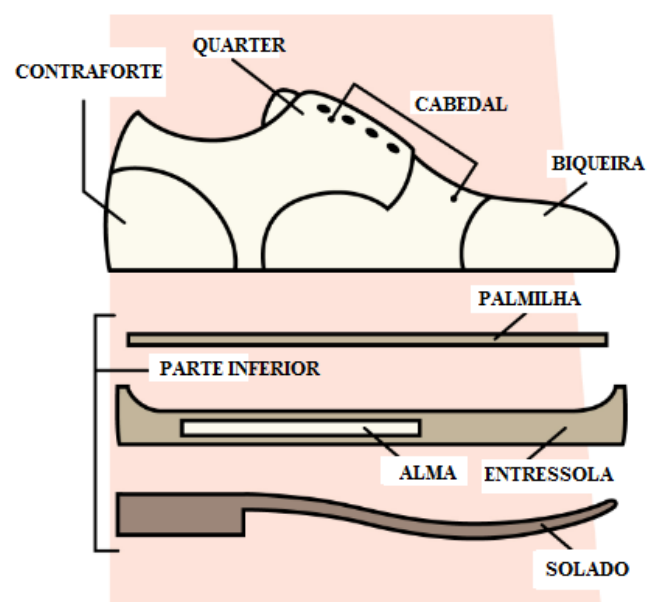

Fonte: Adaptado de (KUNIZSHOES, 2016)

\subsubsection{Palmilha}

A palmilha é composta, normalmente, por uma camada superior, que fica em contato com o pé e é onde, muitas vezes, está estampado o logo da marca e é acoplada na espuma; e; uma parte inferior, frequentemente, com estruturas mais técnicas em materiais poliméricos sintéticos. Estes polímeros podem ser fabricados em espuma moldada, estruturas injetadas e géis, que permitem a absorção de impacto. Dependendo da forma utilizada, é possível desenvolver estruturas para melhorar a ventilação interna (MOTAWI, 2018).

Na Figura 21 é mostrado modelos de palmilhas fabricadas por processo de moldagem (azul) ou placas planas que são cortadas (bege). Geralmente, as palmilhas feitas sob molde são aplicadas em tênis de performance, por ter o contorno dos pés e que possibilitam o melhor suporte. Além disso, nesta aplicação, elas devem ser finas, removíveis e podem utilizar diversas matérias primas como: acetato de vinilo de etileno (EVA) moldado, PU poroso, látex, cortiça, 
borracha expandida ou espuma de polietileno (PE). Nos modelos cortados, muitas vezes, as peças são de pior qualidade, mas há calçados de ótima qualidade que também as utilizam, como sapatos casuais e chuteiras de futebol. As palmilhas cortadas utilizam as seguintes matérias primas: espuma de EVA (pouco duradoura), couro (muito confortável e pode ser feito em várias camadas), espuma de PU (alta durabilidade), borracha de Neoprene ${ }^{\circledR}$ e gel (MOTAWI, 2018).

Figura 21 - Exemplos de palmilhas moldada e cortada (plana)

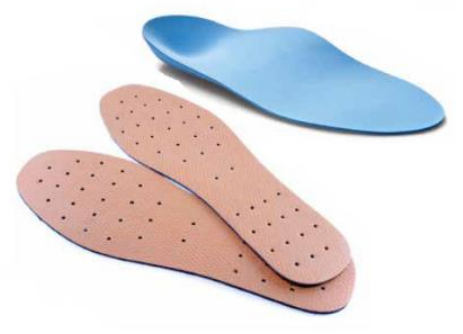

Fonte: Adaptado de (MOTAWI, 2018, p.82)

O material para palmilhas deve ter propriedades adequadas em equilíbrio na maciez para absorver o choque do pé, mas firme para não descer antes que o impacto do choque do calcanhar seja totalmente absorvido e ser resiliente para suportar o movimento. No atributo da perspiração, o calor e a umidade podem resultar em um alto nível de desconforto, devido palmilha ter contato direto com os pés (YICK; YU; LI, 2019).

Além de dar o suporte aos pés, nos calçados comuns, as palmilhas podem ser indicadas sob prescrição médica na busca de correções ortopédicas. Geralmente, são prescritas com objetivos em intervir no calçado, buscando a prevenção, tratamento ou gestão dos problemas musculoesquelético (LEWINSON; WOROBETS; STEFANYSHYN, 2016). As modificações que podem ser feitas na palmilha variam de acordo com a tecnologia empregada, afim de proporcionar: alteração da geometria, aumento da área de contato (molde customizado), ajuste da resiliência (absorção de choque e reuso da energia mecânica), prover suporte assistivo (reforço no calcanhar) e inclusão de sensores (de pressão em movimento e estático) (NAGANO; BEGG, 2018). 


\subsubsection{Entressola}

A entressola é uma camada intermediária entre a palmilha e o solado, e é a parte do solado mais importante, principalmente na função do amortecimento calçado. Também é responsável pelo suporte do arco do pé e da elevação do calcanhar, juntamente com o salto (MOTAWI, 2018; SUBOTNICK et al., 2010). Apesar de sua importância, há modelos que não a utiliza, pois depende do custo do calçado, propriedades requeridas, limitações de espaço e técnica de construção(MOTAWI, 2018).

Como matéria prima para a entressola, diferente de outras partes, o couro não apresenta boas propriedades para absorção dos choques. A borracha natural em placa também não é indicada por ser muito pesada e ter baixa capacidade de absorção de impactos. Com isso, o que mais se aplica atualmente são espumas de células fechadas, que deformam na absorção de energia, em materiais como são: espuma de EVA, espuma de PU, espuma de TPU, borracha (formato de caixa de ovo), TPR (formato de caixa de ovo, Figura 22a), cortiça, borrachas sopradas, pacotes de gel, plásticos injetados e estruturas 3D (Figura 22b) (HERRING, 2010; MOTAWI, 2018).

Figura 22 -Formatos de entressolas em tênis esportivo - (a) borracha em formato de caixa de ovo, (b) impressão 3D

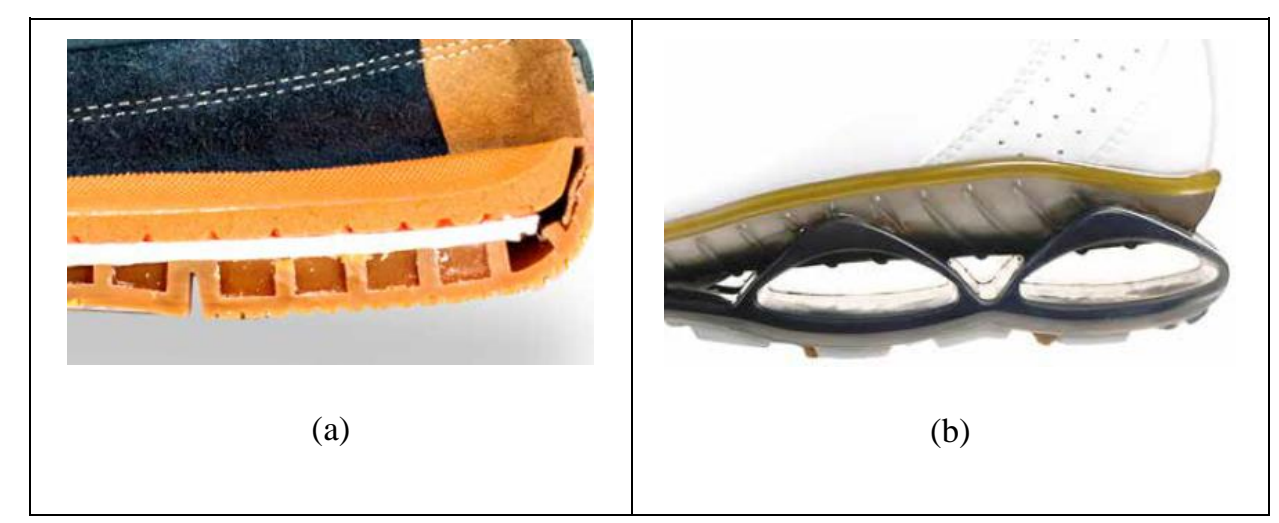

Fonte: (a) (b) Adaptado de (MOTAWI, 2018, p.66 e 67)

Em tênis esportivos e grande parte dos casuais, a entressola é fundamental na função de amortecimento e é indicada a variação da espessura entre 6-10 mm. Neste segmento há também a entressola do calcanhar, que deve medir entre 10-20 mm (MOTAWI, 2018).

No suporte, este componente tem a função de dar segurança aos usuários para realizar as atividades em caminhar ou correr com segurança. As características em forma e densidade 
são fundamentais no fator do suporte (LEVINE, 2010; MOTAWI, 2018). Há casos em que a entressola no calcanhar exibe a mesma densidade em todo o material e, em alguns casos, podem ser adequados, mas quando o indivíduo precisa de uma absorção extra aos choques ou o usuário tem alguma deformação, como o pé em posição em supinação, é necessário utilizar uma variação de densidade. Neste mesmo propósito, estudos apontam que, em geral, o material na lateral da entressola, na parte do salto (calcanhar), deve ter uma compressão intermediária (nem macio e nem rígido), enquanto, no meio, deverá ser entre média ou alta (LEVINE, 2010).

Ademais, outras propriedades da entressola devem ser controladas, como energia de retorno, que é um atributo crítico no amortecimento, pois um material espumado com retorno de alta energia, ou seja, que se recupera rapidamente, é mais capaz de ter conforto. A resistência à compressão da espuma é a habilidade em recuperar o material depois de ser comprimido, se ela for ruim em compressão, o material será achatado com poucos dias de uso. Dependendo da finalidade do calçado, será necessário capacidades diferentes na flexibilidade e peso também (LEVINE, 2010; MOTAWI, 2018; NEBO, 2005).

\subsubsection{Solado}

O desenho do solado é um dos principais fatores para a performance do calçado. Além dele, outras propriedades são requeridas em um solado como: tração, suporte, flexibilidade, peso, resistência ao escorregamento e durabilidade (MOTAWI, 2018). As forças de impacto são transferidas através da entressola para a extremidade inferior, ou seja, para o solado (HERRING, 2010).

Borracha tem sido o material mais escolhido para esta aplicação, pois ela possui maciez e durabilidade. Ainda há uma variedade de outras borrachas que são expandidas e com diversas fontes de matérias primas, que são utilizadas por serem mais leves e macias com amortecimento e flexibilidade. Para durabilidade superior, borrachas de carbono é uma opção já utilizadas (SUBOTNICK et al., 2010).

A tração é um elemento importante na seleção dos materiais e é necessário entender a aplicação para testar o material, como na escolha da direção correta, como em botas para escaladas, há indicação específicas no controle da resistência à tração lateralmente. Nestas botas, precisa-se ter um suporte maior também nas bases do solado ou adicionar placas cortadas em pontos específicos (LEVINE, 2010; MOTAWI, 2018; SUBOTNICK et al., 2010). Na 
definição da durabilidade, depende do ambiente que o sapato será usado e das tarefas a serem realizadas com o sapato e dos materiais escolhidos (MOTAWI, 2018).

Quanto ao quesito da flexibilidade do solado, ela depende do modelo do calçado e, também, da entressola. Assim, um tênis precisa ser mais flexível, enquanto uma bota de montaria necessita de rigidez, ela ainda terá uma haste de aço (alma) para distribuir a carga sem dobrar (MOTAWI, 2018; SUBOTNICK et al., 2010).

Peso também depende da aplicação, seja para um sapato para corrida de longa distância, em que cada grama é crítica, seja para um motoqueiro, quando não há problema que sua bota seja mais pesada (MOTAWI, 2018; SUBOTNICK et al., 2010).

Por sua vez, a resistência ao escorregamento é o critério chave para este componente. Alguns sapatos, utilizados em funções no trabalho, em áreas como manutenção, hospital, e almoxarifado, exigem borrachas antiderrapante certificadas (MOTAWI, 2018).

Para exemplificar a relevância do custo da sola para um fabricante de sapato, há a variação do valor de acordo com o tipo: em calçado comum ela representa 10\% do custo total; enquanto uma apropriada para corrida ou basquete passa a representar uma variação entre 25$35 \%$. Neste caso, o custo é alto devido à tecnologia em design modular. Quando injetada, as matrizes têm alto custo e o grau de dificuldade de criar desenhos é alta, que podem durar meses para desenvolver um modelo (LEVINE, 2010; MOTAWI, 2018).

\subsubsection{Outras partes}

\subsubsection{Haste ou alma}

A haste reforça o meio do calçado e o calcanhar para prevenir a torção. Ela precisa ser completamente rígida ou ligeiramente flexível, dependendo da aplicação (WILLIAMS, 2007). Sapato com solas retas não precisam ter uma haste. Ela "pode ser feita de aço, nylon, madeira, couro arame ou mesmo plástico" (Figura 23) (COSTA, 2013, p.111).

Figura 23 - Alma de ferro

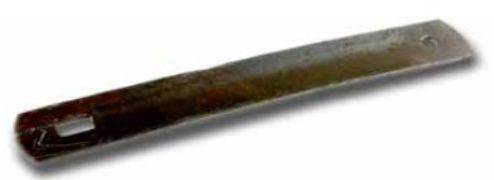

Fonte: Adaptado de (MOTAWI, 2018,p.41) 
Normalmente, utiliza-se alma, inserida na sola, em botas rígidas de escalada, para evitar que a sola flexione, pois o usuário caminha sobre rochas ou outros obstáculos que podem ferir o pé. Outra aplicação fundamental é em sapatos femininos de salto alto, em que a haste auxilia na ancoragem do pé (MOTAWI, 2018).

\subsubsection{Palmilha de Montagem}

A palmilha de montagem tem a finalidade na manutenção do formato da planta do pé, ao dar firmeza ao caminhar. Ainda é cortada no mesmo tamanho da planta da fôrma e auxilia no processo de montagem do calçado e, ainda precisa resistir ao uso (COSTA, 2013). O material mais comum é a celulose, mas pode ser feito de aço, madeira, arame e plástico rígido também (ANDRADE; CORREAA, 2001).

\subsubsection{Salto}

O salto dá suporte na região do calcanhar e auxilia na função do equilíbrio (ANDRADE; CORRÊA, 2001). Normalmente, são feitos de materiais rígidos como plásticos e madeira (COSTA, 2013).

No calçado feminino, o salto pode variar devido às questões estéticas da moda, o exagero na elevação do calcanhar faz com que o corpo concentre na planta do pé, na parte frontal. Além disso, o salto altera o centro da gravidade do corpo, aumentando a pressão na lombar e comprimindo vértebras (DOMJANIC; WALLNER, 2016; LEE; JEONG; FREIVALDS, 2001).

\subsubsection{Colas e Adesivos}

Quase todas as partes do calçado têm cola, normalmente o cabedal é colado nas partes inferiores do calçado. O cabedal, antes de ser costurado, também é colado. A escolha da cola irá influenciar nas propriedades do calçado, como: flexibilidade, dureza, perspiração, durabilidade e bom acabamento. $\mathrm{O}$ uso errado da cola pode deixar um calçado rígido, quente, desconfortável e, também, pode causar quedas ao usuário (MOTAWI, 2018).

As colas, que são usadas para couro, não são as mesmas usadas nos componentes plásticos, aconselha-se consultar o fabricante para a escolha correta. Os solventes, utilizados em adesivos, permitem uma ligação firme, combinada com um tempo de secagem rápido. 
Porém, esses mesmos solventes liberam compostos orgânicos voláteis, que podem prejudicar os trabalhadores no processo industrial e o meio ambiente (MOTAWI, 2018).

\subsubsection{Colarinho}

Colarinho do calçado é mais aplicado para tênis esportivo e é associado à melhoria do equilíbrio e da sensação de conforto na região do tornozelo (NAGANO; BEGG, 2018). A firmeza no pé ocorre devido o contato da gola com o tornozelo, por normalmente ser composta de espuma de poliuretano e coberta com forro de tecido (MOTAWI, 2018). (MOTAWI, 2018). Se o colarinho for mais alto do que o recomendado para o modelo, pode ocasionar queda, por reduzir a possibilidade de movimentação do pé, na distribuições dos pesos do corpo durante a marcha (NAGANO; BEGG, 2018).

\subsubsection{Amarrações}

As amarrações no calçado servem para melhorar a estabilidade e ainda auxiliar a manter o pé dentro do calçado. Elas podem ser em laço, velcro, tiras, fivelas, mas não há determinação sobre qual delas é mais efetiva. Há um estudo que simula matematicamente quais técnicas de trançados de cadarço são mais eficientes e apontam o desenho cruzado como o melhor, porém não é o mais forte e a rigidez do material pode ainda causar a derrapagem do calcanhar (BRANTHWAITE; CHOCKALINGAM, 2019).

\subsection{Matérias primas}

\subsubsection{Couro}

A pele animal é um subproduto que é descartado pela indústria agropecuária, na produção alimentícia. O processo de transformação de pele para produção do couro é chamado de curtimento e é responsável por evitar o processo de decomposição (MALUF; HILBIG, 2010).

A estrutura da pele do boi pode ser vista na Figura 24, e suas camadas são divididas em: epiderme, derme e carne. A derme é a parte que será processada no curtimento, ela corresponde a $85 \%$ de toda a espessura da pele e é composta principalmente de colágeno (proteína). A camada superior da derme, mostrada na faixa mais escura da Figura 24, é chamada de flor do couro. Ela é mais densa, resistente e mais valorizada, por receber texturas, 
efeitos de brilho e, acabamentos especiais, como o nobuck. A camada inferior é espessa e, por isso, é dividida ao meio, ela é conhecida no mercado como raspa ou camurça (MOTAWI, 2018).

Figura 24 - Partes que compõe a pele bovina

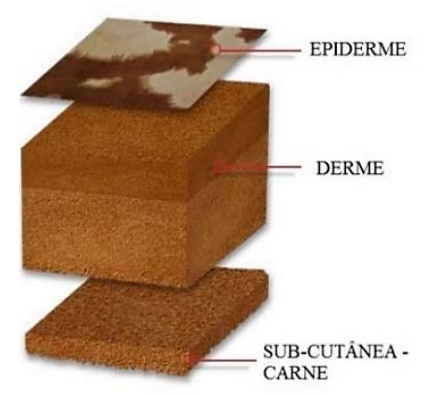

Fonte: Adaptador de (MOTAWI, 2018, p.6)

O processo de fabricação do couro percorre diversas etapas e está representado na Figura 25, em que é mostrado o fluxo geral do processo (do abate ao acabamento) e, no Quadro 3, há o detalhamento desses processos e subprocessos. As indústrias que processam o couro em pele não realizam necessariamente todas as etapas apresentadas na Figura 25 e no Quadro 3, por isso, muitas vezes, denota-se que há diferentes tipos de curtumes. São eles: integrado - faz todas as operações, desde o couro cru até acabado; etapa w $\underline{\text { et blue }}$ - processa-se desde o cru até o curtimento ao cromo e tem esse nome devido ao aspecto úmido e azulado, após o tratamento com o cromo; semiacabado (ou etapa crust) - utiliza o wet blue como matéria-prima

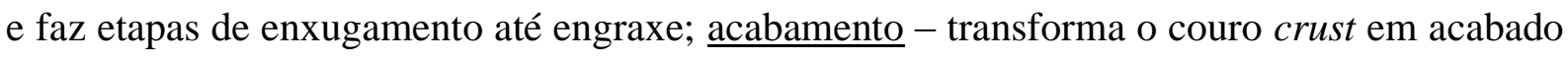
(FARIA; PACHECO, 2015). Cada etapa do tratamento da pele tem seu valor de mercado e essa separação também ocorre na exportação, em que as peles são vendidas em condição wet blue, semiacabado ou acabado (CICB, 2014).

Figura 25 - Etapas do processamento do couro

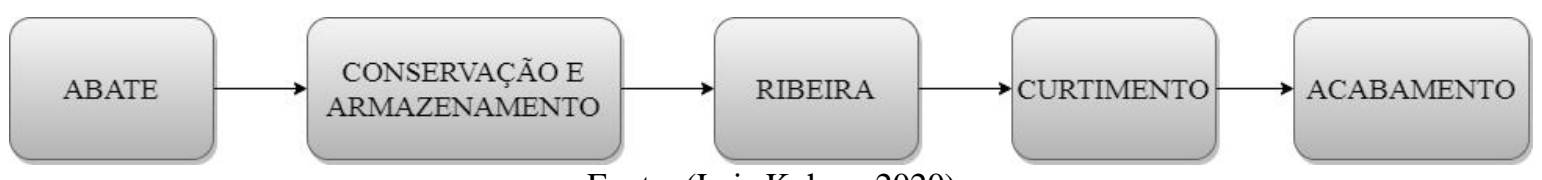

Fonte: (Lais Kohan, 2020) 
Quadro 3 - Processo Industrial do Couro (versão detalhada)

\begin{tabular}{|c|c|c|c|}
\hline \multicolumn{4}{|c|}{ Processo Industrial do Couro } \\
\hline Etapas & \multicolumn{2}{|l|}{ Subprocessos } & Descrição \\
\hline Abate & \multicolumn{2}{|l|}{ Esfola } & Retirada da pele em até 3 ou 4 horas \\
\hline \multirow{3}{*}{$\begin{array}{l}\text { Conservação e } \\
\text { armazenamento }\end{array}$} & \multirow[b]{2}{*}{ Conservação } & Pele fresca & $\begin{array}{l}\text { Sem tratamento (baixas temperaturas, } \\
\text { estocagem em até } 3 \text { horas) }\end{array}$ \\
\hline & & Cura & $\begin{array}{l}\text { Empilhamento com sal ou mergulho em } \\
\text { salmoura (temperaturas maiores, } \\
\text { estocagem por meses) }\end{array}$ \\
\hline & Classificação & Peso e aplicação & Por peso da peça e finalidade \\
\hline \multirow[t]{2}{*}{ Ribeira } & \multicolumn{2}{|c|}{$\begin{array}{l}\text { Banhos - Pré-molho, Remolho, } \\
\text { Depilação, Lavagem, Purga, } \\
\text { Lavagem, Píquel }\end{array}$} & $\begin{array}{l}\text { Tratamentos químicos das peles para } \\
\text { sua limpeza ou para condicionamento } \\
\text { de suas fibras }\end{array}$ \\
\hline & \multicolumn{2}{|c|}{ Tratamentos físico-mecânicos } & Remoção de impurezas e corte \\
\hline \multirow{3}{*}{ Curtimento } & Mineral & & $\begin{array}{l}\text { Método principal de curtimento, usa-se } \\
\text { sulfato de cromo, tempo curto e } \\
\text { qualidade das peças. Restrições por } \\
\text { problemas ambientais. }\end{array}$ \\
\hline & Vegetal & & $\begin{array}{l}\text { Taninos contidos em extratos vegetais, } \\
\text { alto custo, usados mais para solas. }\end{array}$ \\
\hline & Sintético & & $\begin{array}{l}\text { Curtentes orgânicos, resultado } \\
\text { uniforme, custo médio. }\end{array}$ \\
\hline Pré-acabamento & $\begin{array}{l}\text { Operações físico } \\
\text { mecânicas }\end{array}$ & $\begin{array}{l}\text { Estiramento, } \\
\text { secagem, e } \\
\text { impregnação }\end{array}$ & $\begin{array}{l}\text { Adicionar propriedades físicas aos } \\
\text { couros. }\end{array}$ \\
\hline Acabamento & \multicolumn{3}{|c|}{ Acabamento, prensagem e medição } \\
\hline
\end{tabular}

Fonte: Adaptado de (FARIA; PACHECO, 2015)

A etapa do Ribeira (Quadro 3) é fundamental para evitar a proliferação bacteriana, principalmente no subprocesso de remolho. Nessa fase, é feito tratamento com diversos insumos: água (com dureza baixa, temperatura entre $18-28^{\circ} \mathrm{C}$ ), álcalis (para elevar o $\mathrm{pH}$ e saponificar as gorduras com sabão), tensoativos (para diminuir a tensão superficial da água), enzimas (na limpeza interfibrilar), bactericidas (para impedir sua contaminação) etc. (LEAL, 2007).

O processo de curtimento é a etapa que transforma as peles, já previamente tratadas (no processo Ribeira) em materiais estáveis, que já não se deterioram mais (FARIA; PACHECO, 
2015). O curtimento mineral é o processo mais usado e, normalmente, utiliza o crômio (sulfato básico de cromo), que contém 33\% de elementos básicos e $23 \%$ de óxido de crômio (III) $\left(\mathrm{Cr}_{2} \mathrm{O}_{3}\right)$. Ele é conhecido pela versatilidade, excelente estabilidade hidrotermal, boa capacidade no tingimento e maciez. Porém, o crômio (III) causa consequências à fisiologia humana, como: alterações no metabolismo, mutações genéticas e alterações no DNA (ORUKO et al., 2020; WANG et al., 2017). Ainda há o problema do crômio (III) no efluente, pois ele pode ser convertido a crômio (VI), devido à presença de agentes oxidantes e esse composto é ainda mais nocivo à natureza humana, por ser cancerígeno, mutagênico e alergênico. E, ainda, ele pode provocar mortalidade aos organismos presentes na água (CHINA et al., 2020; PATRA; PRADHAN; PATRA, 2019).

Além do crômio, nos processos de curtimento e pré-tratamentos são utilizados outros químicos, que também poluem as águas, como: óleos, corantes, bactericidas, resinas, biocidas, sódio, sulfureto, cal, surfactantes e fungicidas (ALOY et al., 1976, apud NALYANYA et al., 2019). A questão é tão complexa e preocupante em relação aos problemas ambientais, causados pela utilização dos produtos químicos no curtimento, que há diversas pesquisas que apontam soluções no tratamento desses efluentes. Assim, o tratamento é feito por variadas técnicas: osmose reversa, micro e nano filtração, oxidação eletroquímicas, tratamentos biológicos (LOFRANO et al., 2013; ZHANG et al., 2016); além de proposta para reuso da água (DE AQUIM; HANSEN; GUTTERRES, 2019). Porém, esses tratamentos podem implicar no gasto intensivo de energia e altíssimo investimento e manutenção, tornando-os inviáveis (ZHANG et al., 2016).

Outros métodos de curtimento, com base em produtos derivados do petróleo, são também usados como alternativos ao crômio e, normalmente são de origem orgânica, com base em taninos sintéticos ou resinas, que proporcionam boa uniformidade no couro (FARIA; PACHECO, 2015). Eles fazem parte de um extenso conjunto de produtos químicos como: fenol, naftaleno, formaldeído, à base de melamina, e resinas acrílicas. O problema é que estes compostos conferem baixa taxa de biodegradabilidade (MUNZ et al., 2009 apud LOFRANO et al., 2013).

Uma das possibilidades do uso de um agente de curtimento menos agressivo ao meio ambiente é a partir de taninos vegetais (NALYANYA et al., 2019). Esse agente envolve a interação com o colágeno, a partir de ligações por pontes de hidrogênio, entre o oxigênio do peptídeo do colágeno e grupos poli fenólicos $(-\mathrm{OH})$. Esse processo para ser efetivo, depende de algumas variáveis, como: $\mathrm{pH}$, temperatura, concentração do tanino, sal e condição do couro. Os 
mais comuns taninos vegetais são extraídos de cascas e folhas de árvores como Quebracho, Castanheira (10,7\%), espécies de Acácia e muitas outras ainda são pesquisadas (AUAD; SPIER; GUTTERRES, 2020; BHAVYA et al., 2019).

A comercialização do couro é feita em peças, a partir da medida de $30 \times 30 \mathrm{~cm}$ ou o chamado pé quadrado. A falta de uniformidade da pele dos animais é considerada um problema que afeta a qualidade do produto acabado. A não uniformidade é causada por manchas de fogo, cicatrizes, cortes, dobras, marcação de lote, bernes, etc. (ROLO, 2016).

No ramo calçadista, o couro bovino é uma das matérias primas mais antigas e tradicionais do calçado, que é utilizado com mais frequência em cabedais (Figura 26), além de solas e forros (ROLO, 2016). Ele apresenta excelentes propriedades em durabilidade, flexibilidade, permeabilidade e maleabilidade; este último quesito facilita bastante o calce e, se diferencia, dentre outros materiais (MOTAWI, 2018; WILLIAMS, 2007). Somadas às essas questões, a atratividade estética também contribui na valorização do material, que confere um brilho e lustre único, e efeitos da coloração (Figuras 26 a e c). Apesar das ótimas propriedades, a sua aplicação no segmento está sendo reduzida ao longo do tempo, principalmente, devido ao alto preço praticado, em relação aos tecidos ou polímeros (MOTAWI, 2018). Mesma situação vem ocorrendo no Brasil, na substituição dessa matéria prima, como já citado anteriormente.

Figura 26 - Exemplo de calçado em couro bovino - A - Bota camurça (Sidewalk), B Sandália napa semi brilho (Wishin), C - Sapato social atanado (Sergio`s)

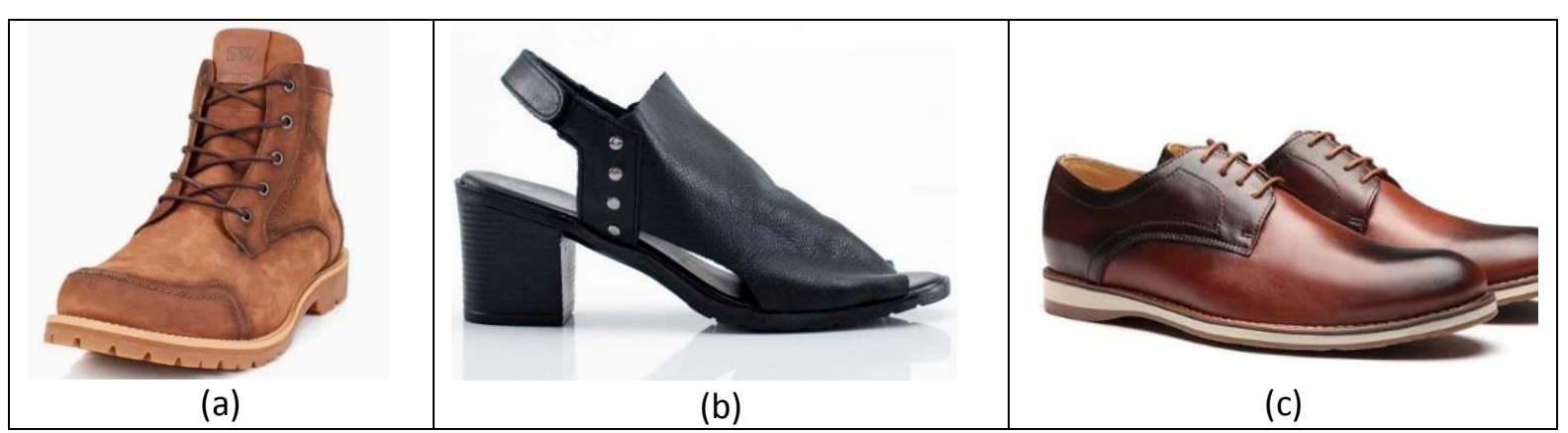

Fonte: (a) (SIDEWALK, 2020) (b) (WISHIN, 2020) (c) (SERGIO’S, 2020)

\subsubsection{Materiais têxteis}

Têxteis são constituídos de matérias primas na forma de fibras, fios ou filamentos, em diferentes arranjos (flocos, fios cabos, tecidos, não tecidos). Em aplicações técnicas, os têxteis 
necessitam de "performance bem determinada, visando a praticidade, segurança, economia e durabilidade" (PEREIRA, 2005, p.6).

Figura 27 - Exemplos das matérias primas das fibras têxteis

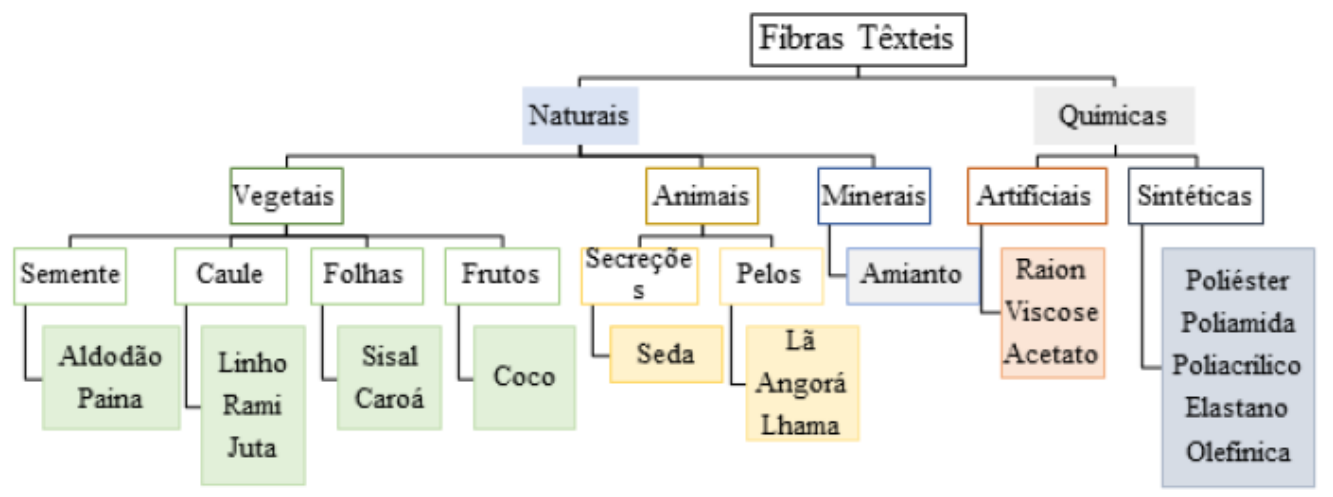

Fonte: (BARBOSA et al., 2004, apud LAKTIM, 2018, p.30)

A origem e as propriedades das fibras são importantes para a definição da aplicação dos têxteis. A origem tem duas vertentes principais: natural, subdividida em vegetal, animal e mineral; e química, em fibras artificiais e sintéticas (Figura 27) (COSTA; ROCHA, 2009). Elas são caracterizadas pelos aspectos dimensionais, mecânicos, químicos, térmicos e por capacidade de absorção (SILVA, 2018). Tais aspectos são mostrados no Quadro 4 e as propriedades também são indicadas, divididas por cada categoria.

Quadro 4- Propriedades das fibras têxteis

\begin{tabular}{|c|c|}
\hline Categoria & Propriedade \\
\hline \multirow{4}{*}{ Dimensional } & Comprimento \\
\hline & Finura \\
\hline & Secção transversal \\
\hline & Título \\
\hline Mecânica & Tração e alongamento \\
\hline Absorção & Recuperação da umidade - Regain \\
\hline \multirow{3}{*}{ Química } & Resistência alcalina \\
\hline & Resistência ácida \\
\hline & Resistência a agentes oxidantes \\
\hline \multirow{4}{*}{ Térmica } & Condutividade \\
\hline & Amolecimento e derretimento \\
\hline & Combustibilidade \\
\hline & Decomposição \\
\hline
\end{tabular}


Além das fibras, a estrutura dos tecidos também é importante para determinar onde serão empregados. Na Figura 8 (vide item 4.2.4), os tecidos foram apresentados, de acordo com uma classificação mais geral, dividida em: malhas, tecidos e nãotecidos. Dentre esses grupos, há diversas tecnologias em maquinários e possibilidades em entrelaçamentos, definido como padronagem têxtil. Assim, a seguir, serão discriminados as principais fibras, tecidos e maquinários utilizados em calçados.

O nãotecido (TNT) é uma estrutura plana, flexível e porosa, constituída de véu ou manta, que são orientados e consolidados, por processo mecânico, químico, ou térmico, ou combinação entre eles (ABINT, [s.d.]). Ele é amplamente utilizado nos calçados, na "biqueira, contraforte, palmilha, substrato para cabedal, forro e outros; contribuindo para a estrutura e beleza do calçado"(COSTA, 2003, p.150).

Conforme dados da Ober (http://www.ober.com.br/), uma das maiores empresas fornecedoras de nãotecidos no Brasil, as matérias primas utilizadas no segmento de calçado são feitas em: poliéster, polipropileno, viscose e mistas (OBER, [s.d.]). Esses nãotecidos são fabricados por duas tecnologias principais: a primeira, a spunlace, em que o entrelaçamento é feito por jatos de água, que proporcionam toque muito suave e com poucas fibras soltas na superfície, o que confere maior resistência, quando comparado aos agulhados (Figura 28a); outro tipo fornecido é, justamente, o agulhado, em que agulhas fazem a união das fibras, mas que as deixam quase soltas, que são facilmente retiradas por atrito e, muitas vezes, os formatos dessas agulhas deixam marcas no produto (Figura 28b) (ABINT, [s.d.]).

Figura 28 - Não tecidos utilizados em calçados, (a) spunlace, (b) agulhado

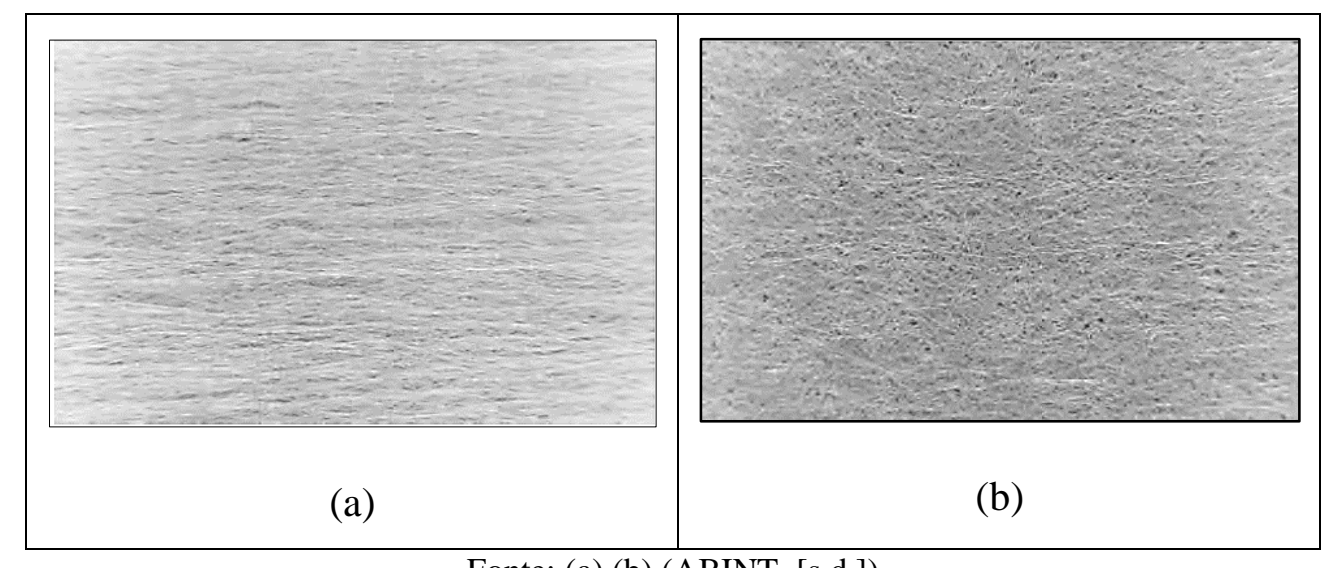

Fonte: (a) (b) (ABINT, [s.d.]) 
A estrutura de tecido plano, isto é, entrelaçada em tear é mostrada na Figura 29a. Nessa tecnologia, quando aplicada aos sapatos, é comum a utilização de fibras naturais de algodão em estrutura denim (Figura 29b) e lona (ZHAI, 2011). As matérias primas de algodão têm a vantagem, devido ao conforto, por permitir absorção de água e permeabilidade ao vapor de água (suor), aliados ao fator de design e resistência (ZHAI, 2011). As desvantagens são relacionadas à demora para secagem, o peso adquirido (RICHIE, 2010) e a sensação de frio quando molhado (DAANEN, 2015), podendo interferir na escolha do tecido para determinados tipos de calçados.

Figura 29 - Tecidos planos em calçados - (a) tear (b) calçado em cabedal de denim

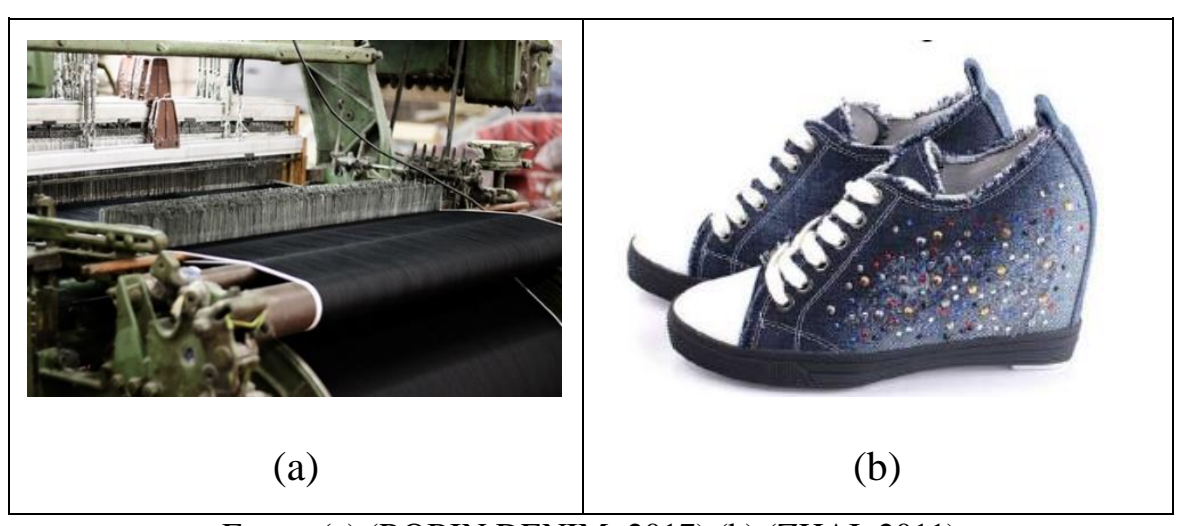

Fonte: (a) (ROBIN DENIM, 2017) (b) (ZHAI, 2011)

A estrutura em passamanaria, isto é, tecidos estreitos ou cordões (constituindo adornos utilizados nos artigos de moda), pode ter alguma função no sapato, como os fechos em cadarços de tênis, elásticos, zíper; ou ser utilizada apenas com caráter decorativo, em fitas, tranças etc. (DEVI et al., 2018). É comum a utilização de fibras naturais em cordões e trançado de juta para recobrimento de saltos (Figura 30b) (SANTOS; RAZZA; SANTOS, 2015). Fibras sintéticas também são usadas nessa estrutura, principalmente em poliéster e poliamida, aplicadas em modelos casuais ou esportivos (como exemplo: em cadarços Figura 30c), importante salientar, que essas matérias-primas conseguem adquirir cores intensas e fluorescentes (UM, 2007). Ainda há máquinas especializadas para o segmento, como exemplo, o tear para fitas e elásticos da Figura 30a (TEXMAN, [s.d.]). 
Figura 30 - Passamanaria - (a) tear agulha 10/30, (b) sandália com solado Anabela recoberto em trançado de sisal, (c) cadarço $6 \mathrm{~mm} 100 \%$ poliéster

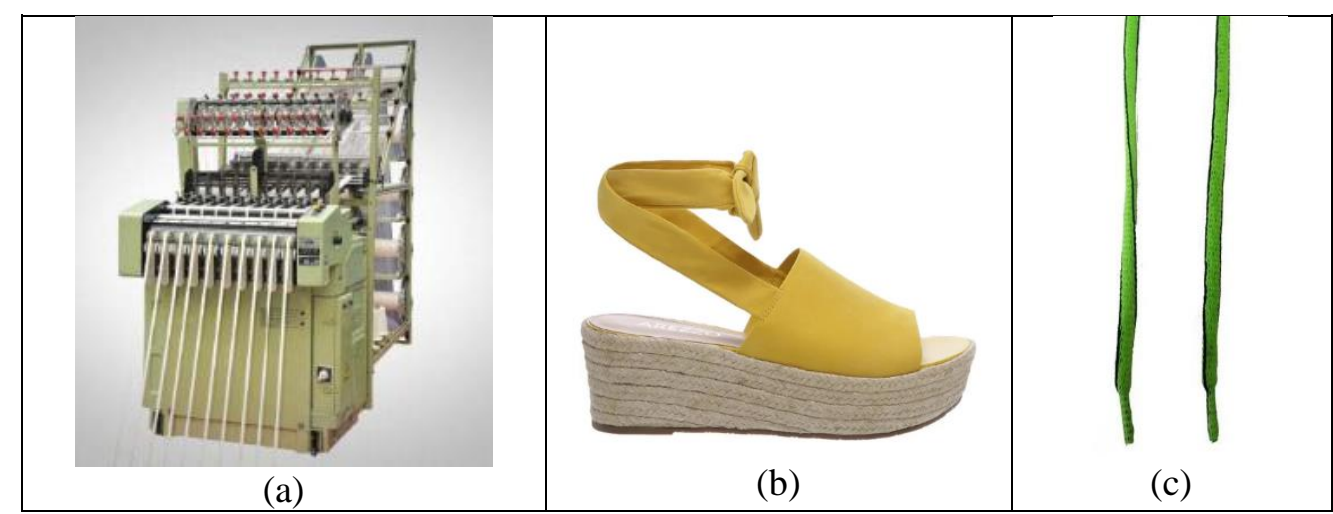

Fonte: (a) (TEXMAN, [s.d.]) (b) (AREZZO, 2020b) (c) (NETCADARCOS, [s.d.])

Na malharia, a tecnologia envolve duas estruturas principais. A primeira, é a malharia circular, em que há diferentes modelos que apresentam variações em especificações dos maquinários, como: número de agulhas por polegada, uma frontura/camada de agulhas ou duas, posições de alinhamento agulhas, limite de tamanho de desenho etc. Segue exemplos de tecidos bem difundidos na malharia circular em: meia malha (camiseta ou piquet), interlock (agulhas entre fronturas intercaladas) ou ribana (agulhas alinhadas), malha dupla (duas fronturas tecidas), jacquard (desenhos com várias cores e tamanhos) etc. A segunda é a malharia de urdume, que também tem produções de ligamentos e com diferentes equipamentos para produção dos tecidos, como exemplos: malhas produzidas em teares Raschell e Kettenstull. Ambas tecnologias possuem propriedades especiais quanto à rigidez da estrutura têxtil, uma característica importante na construção de calçados (STEGMAIER; MAVELY; SCHNEIDER, 2005).

Na malharia de urdume, a estrutura mesh é uma das mais utilizadas em cabedais, feitos em $100 \%$ poliéster ou com misturas em poliamida (Figura 31b). A máquina Raschell para tecer esse tecido possui sete barras de conjuntos de carreteis e tem um custo elevado (Figura 31a). Esse tecido possui duas camadas separadas e conectadas por fios monofilamentos, possui boas características em isolamento térmico (devido ar armazenado entre as camadas da estrutura) e alta resistência elástica (Figura 31b) (RAJENDRAN; ANAND, 2014; STEGMAIER; MAVELY; SCHNEIDER, 2005). Além de uso em cabedais, há pesquisas designando-o para substituição de palmilhas, por ter características como: porosidade, permeabilidade e conforto (LO et al., 2018; RAJAN et al., 2016); e, inclusive, há indicação de uso para auxiliar na redução de alguns problemas no pé, como na proteção à ulceração (RAJENDRAN; ANAND, 2014; YICK; TSE, 2013). 
Figura 31 - Máquina malharia de urdume Raschel (7 barras) - modelo Mayer RD72-12EN

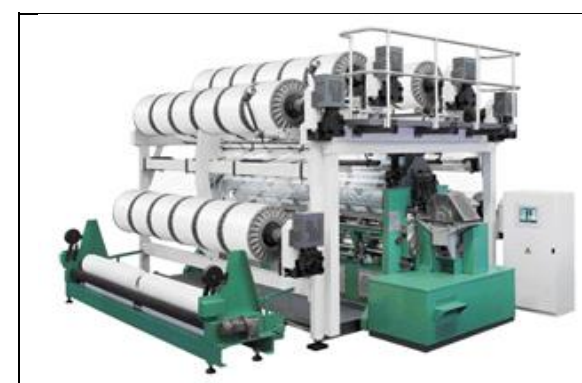

(a)

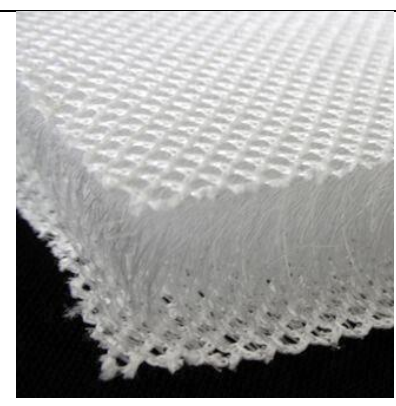

(b)

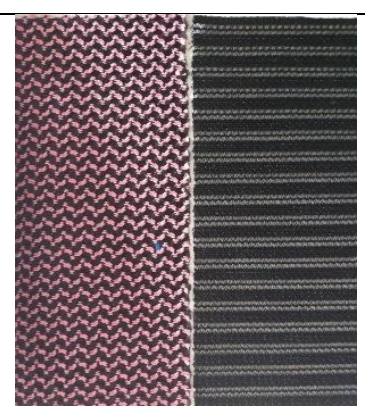

(c)

Fonte: (a) (KARLMAYER, 2014) (b) (CHANGSHU DAFA WARP KNITTING CO. LTD, [s.d.]) (c) (Lais Kohan, 2020)

Outras estruturas em tecidos em malharia de urdume são mostrados na Figura 31c, que normalmente são fabricados por materiais sintéticos (poliéster e poliamida). A escolha dessas matérias primas é associada às características em baixa absorção de água (hidrofóbica), rápida secagem, baixo peso e baixo custo; a propriedade hidrofóbica do poliéster é compensada devida à geometria desses tecidos, que possuem áreas vazadas e permitem a circulação de ar. Importante destacar que, apesar da excelente estrutura de malhas de urdume, há uma grande desvantagem em relação a escolha dessas máquinas, devido ao custo efetivo, porque há necessidade de preparação dos fios, o que faz que haja muito tempo gasto para preparação deles e, na montagem da máquina, vide a quantidade de carreteis usados na Figura 31a (RAJENDRAN; ANAND, 2014).

Em malharia circular, são feitos tecidos mais elásticos, no sentido da trama (horizontal) (Figura 32a). É muito comum a utilização dessa tecnologia aplicada em forros dos calçados, principalmente para àqueles sem desempenho esportivo (em testes mecânicos rígidos) (BLAGA; MARMARALI; MIHAI, 2011); assim, no calçado feminino e infantil, eles são aplicados em padronagens simples, como o tecido cacharrel (malha circular dupla face) na Figura 32b. Mesmo assim, eles podem variar em qualidade e têm várias opções em gramatura (medida comum de tecidos que relaciona peso por área $-\mathrm{g} / \mathrm{m}^{2}$ ), dependendo da finalidade do calçado (BLAGA et al., 2015). 
Figura 32 - Malharia circular: (a) tear listrador (b) forro de cacharrel (calçados Beira Rio)

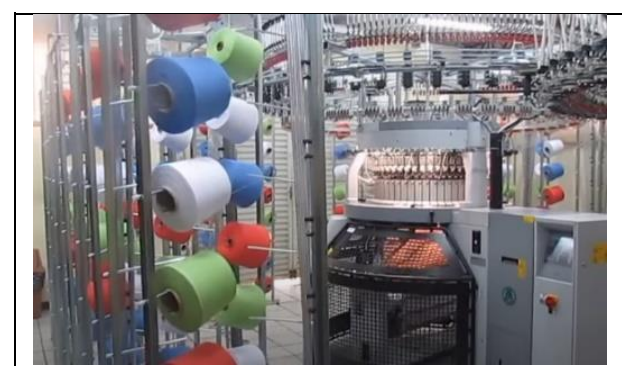

(a)

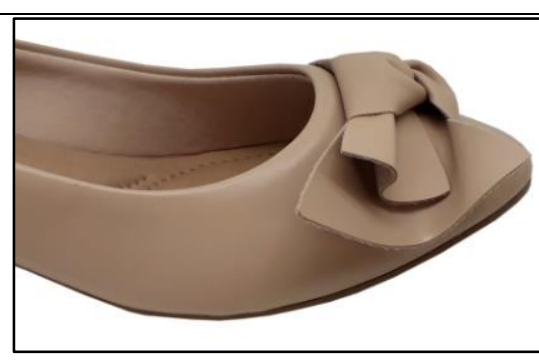

(b)

Fonte: (a) (IFSC JARAGUÁ DO SUL, 2015) (b) (RAINHA CALÇADOS, 2020)

A tecnologia de malharia, que revolucionou o setor, foi a conhecida no mercado como Fly-knit, mas o nome do maquinário correto é Flat-knit, em que são tecidos em máquinas de malharia plana que passaram a tecer as gáspeas, individualmente, eliminando as etapas de corte e costura de forros, línguas, entre outras partes, como exemplos, as Figura 17 (item 4.3.1) e a Figura 33a (LU et al., 2016). Foi a partir de 2015, que a tecnologia Fly-knit foi introduzida nos tênis das marcas Adidas ${ }^{\circledR}, \mathrm{Nike}^{\circledR}$ e inovaram ao fazerem as gáspeas já estruturadas. Inclusive essas empresas ainda disputam entre si a patente, porém, ninguém atingiu os pré-requisitos para conquista-la (WEST, 2019).

Figura 33 - Tecnologias mais recentes em malharia 4D (dimensões) - (a) tecido em Fly-knit (com estrutura de reforço ligamento ribana), (b) Tecido feitos na máquina double needle bar Raschel - 4D - RDPJ 6/2 EL

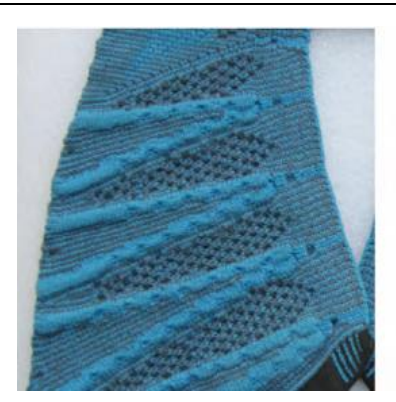

(a)

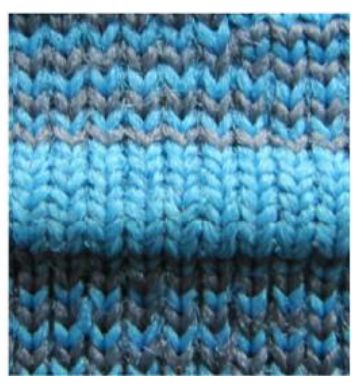

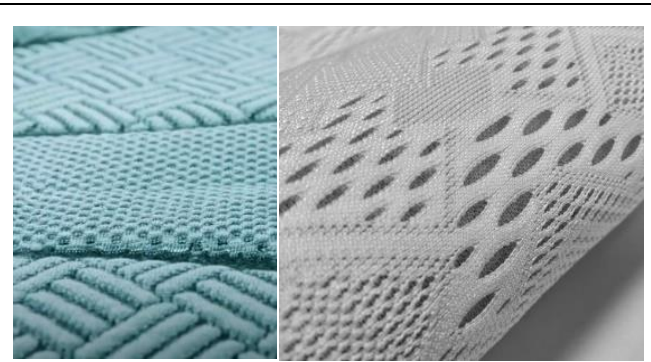

(b)

Fonte: (a) (LU et al., 2016) (b) (KARLMAYER, [s.d.])

Neste sentido, a ITMA 2019, a maior feira de maquinário têxtil (ITMA, 2019) apresentou várias máquinas que produzem tecidos no conceito de gáspea pronta, por diferentes tecnologias e fabricantes. No evento, houve um destaque dos fabricantes tradicionais, que adaptaram máquinas já existentes, e atualizaram-nas com novas funções, como exemplo, os 
modelos Karl Mayer jacquard (Figura 34a) e a tradicional máquina de meias da marca Santoni, transformada para tricotar padrões de logotipo colorido, em alta definições, com 4 alimentações (cores) (Figura 34b) (WEST, 2019).

Figura 34 - Malharia circular: (a) Máquina Karl Mayer \& Cia jacquard duplo (OVJA 1.1 EETT) e (b) Santoni (X Machine Sock/shoe (C)

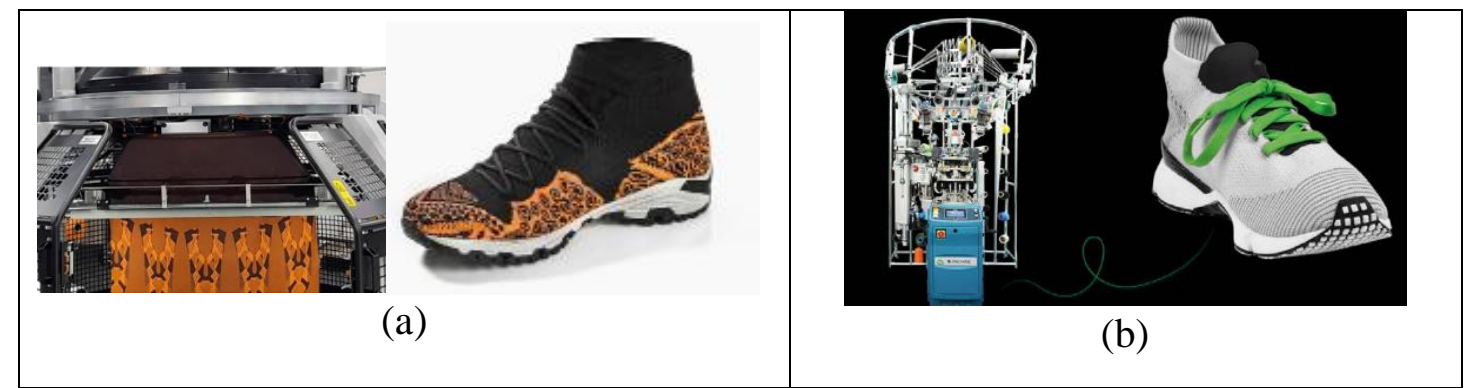

Fonte: (a) (b) (WEST, 2019)

Há uma crítica sobre a qualidade dos tecidos em estrutura flat-knit, apontando-nos a baixa eficiência produtiva e instabilidade estrutural e, também, indicando que malharia de urdume jacquard (tecidos mesh desenhados) teriam melhor estabilidade dimensional e seriam mais adequadas aos tênis esportivos (LI; ZHANG; JIANG, 2017). Nesse sentido, para ilustrar a diferença entre os tecidos citados, a Figura 33a mostra o flat-knit, e a Figura 31b, o mesh. Na ocasião da feira ITMA 2019, foi exposta a máquina mais recente da marca Karl Mayer (modelo descrito na Figura 33b), em tecidos em 4 dimensões (WEST, 2019).

Apesar dos tecidos em poliéster e poliamida serem, atualmente, as matérias primas mais utilizadas nos têxteis em calçados, há diversos artigos mostrando a possibilidade em combinar matérias primas com o intuito de obter melhores características em conforto e desempenho, por misturas em fios e tecidos. Com isso, fios mistos em poliéster e algodão, por mistura íntima (na fase da fiação), foram tecidos em estrutura meia malha e conseguiram atingir boas propriedades em resistência à fricção, pilling e módulo elástico (BLAGA; MARMARALI; MIHAI, 2011). Fios com matérias primas diferentes foram entrelaçados na fase de produção do tecido, em algodão/viscose de bambu, algodão/Liocel ${ }^{\circledR}$ em malha interlock, todos apresentaram boas condições em coeficiente de fricção (acima de 0,7) para aplicação em forros de sapatos (BLAGA et al., 2015). Tecidos duplas faces em malharia circular foram testados para cabedais, com uma face em Modal $^{\circledR}$ (viscose de alta resistência mecânica) e, outra, em microfibra de poliéster, e exibiram boa capacidade de secagem e conforto ao usuário (BLAGA et al., 2015). 
Mesh com lados diferentes em poliéster e viscose de bambu, também apresentaram boas propriedades de perspiração (SOARES et al., 2018).

\subsubsection{Polímeros Sintéticos}

\subsubsection{Laminados sintéticos}

Laminados sintéticos pertencem à uma classe de materiais com uma imensa variedade de cores, texturas, composições e, ainda, podem variar em preços. Esses materiais sintéticos aplicados nos cabedais de calçados, principalmente no segmento feminino, é comum usar texturas e cores que são como "cópias" da aparência de têxteis, madeira, metal, couro natural, cortiça, entre outros (MOTAWI, 2018).

Os laminados sintéticos são construídos por duas ou três camadas. A parte externa é feita por processo seco ou molhado (líquido) e também passa por etapas, que podem ser impressas, pigmentadas, ou gravadas em relevo (MOTAWI, 2018). A parte de trás, que dá suporte, é formada por tecidos ou nãotecidos em fibras de poliéster, microfibra de poliéster, espumas de PVC ou PU (MOTAWI, 2018; ROH; OH; KIM, 2013).

Há dois processos principais de produção de laminados sintéticos: via úmido e via seco. O processo via úmido é feito por uma resina líquida, que, em contato com o papel com textura, transferirá, após o processo de cura, a aparência do papel. Na cura, a resina torna-se sólida e a camada de suporte é aderida, por pressão e calor no cilindro. Já o processo seco é feito pela adesão de um filme de PU, que normalmente é fino e com efeitos gráficos. A segunda etapa é também a junção do suporte, através de um filme termocolante, que, por pressão e temperatura, une as partes (MOTAWI, 2018).

As categorias principais em laminados sintéticos são: PVC, PU, filme de TPU e microfibra sintética. O PVC é produzido por 3 etapas, através do processo úmido de material plástico; mesmo sendo o tipo mais barato, são amplas as possibilidade de acabamentos, porém, ele apresenta o toque mais rígido e com baixa capacidade de permeabilidade ao ar e umidade, quando comparado ao PU (Figura 36a) (DREGER et al., 2018). O PU é produzido em uma camada fina plástica, que pode variar a formulação e tornar o produto mais resistente, para aplicar, por exemplo, em biqueira de tênis. Com grande variedade em superfície, o PU apresenta toque macio, elástico (Figura 35) e melhor permeabilidade ao ar e umidade (ANDRADE; CORRÊA, 2001). O TPU é extrudado em filmes flexíveis, como borracha, em qualquer cor e textura (Figura 36c). E, a microfibra sintética é formada por microfibras de poliéster, em 
superfícies escovadas, que substituíram, ao longo do tempo, a camurça ou nobuck de couro, nos calçados esportivos; ainda podem ser coloridas, por impressão e gofradas, ou até por espalmagem (processo semelhante ao PVC ou PU em processo úmido) (Figura 36b) (MOTAWI, 2018).

Figura 35 - Laminado de PU - variedades de texturas e cores

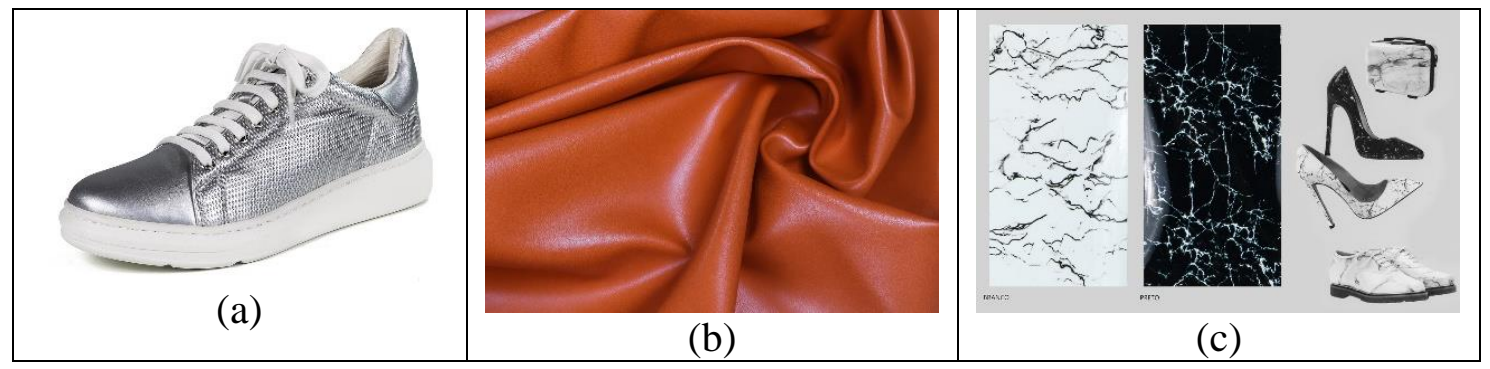

Fonte: (a) (b) (c) (LIAISON, 2020)

Figura 36 - Laminados sintéticos: (a) PVC em diversas gravações, (b) microfibra de PU, (c) TPU aplicado no cabedal de tênis

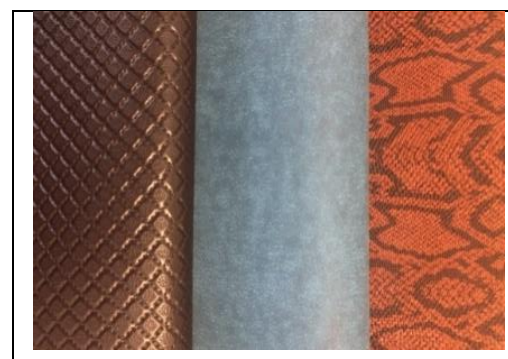

(a)

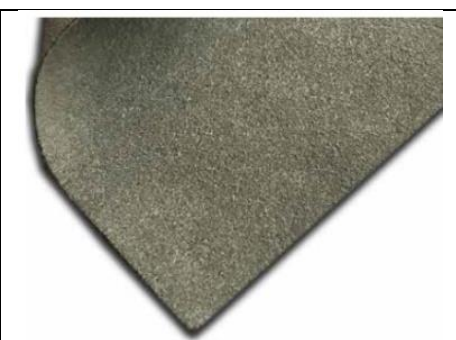

(b)

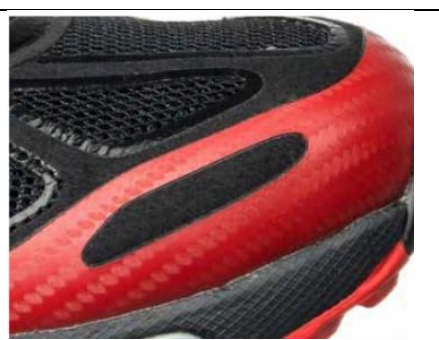

(c)

Fonte: (a) (Lais Kohan, 2020); (b) e (c) (MOTAWI, 2018, p.30)

\subsubsection{Termoplásticos e termofixos}

Termoplásticos e termofixos fazem parte das principais categorias do universo dos plásticos, cujo mercado calçadista moderno produz em massa com essas matérias primas. Termoplásticos podem ser derretidos e conformados, enquanto quente e, novamente, refundido depois de prontos. Enquanto termofixos podem ser modelados a calor e, uma vez transformados, tornam-se irreversíveis, pois o processo de cura das moléculas, deixam-nas ligadas e não podem ser quebradas por calor (MOTAWI, 2018). No Quadro 5, a seguir, é mostrado os principais polímeros termofixos e termoplásticos, utilizados em solados e as vantagens de uso são destacadas, através da apresentação das características principais. 
Quadro 5 - Principais polímeros utilizados em solados de calçados

\begin{tabular}{lll}
\hline MATERIAL & TIPO & CARACTERÍSTICAS \\
\hline NR (natural - Látex) & Elastômero & Elasticidade e tração na ruptura \\
NBR (sintética) & Elastômero & Resistente ao rasgo e abrasão \\
PU & Termofixo & Leveza e conforto \\
TR & Termoplástico & Flexibilidade e reciclagem \\
EVA & Termoplástico expandido & Fácil pigmentação e leveza \\
TPU & Termoplástico & Resistência ao rasgo e reciclagem \\
PVC & Termoplástico & Boa adesão, isolamento e reciclagem \\
\hline
\end{tabular}

Os polímeros termoplásticos são mais comuns nos calçados, como exemplificado acima (Quadro 5), mas há ainda uma ampla variedade não citada, como: poliamida (náilon), ABS, policarbonato, TPE, TPU, TPR, PVC, filmes transparentes (Surlyn ${ }^{\circledR}$, com alta tenacidade ao impacto, resistência à abrasão e resistência química), polietileno e polipropileno. O processo de moldagem por injeção é o método mais comum para essa classe de produtos, principalmente, na fabricação de acessórios para calçados (rendas, logotipo, contraforte, fivelas etc.). Máquinas de injeção utilizam grânulos (pellets) de plástico aquecidos, que derretem e são inseridos no molde sob pressão e, depois, são resfriados e as peças ficam prontas. Os moldes podem ser feitos em qualquer tamanho (Figura 37) (MOTAWI, 2018).

Figura 37 - Processo de injeção: molde e peça pronta

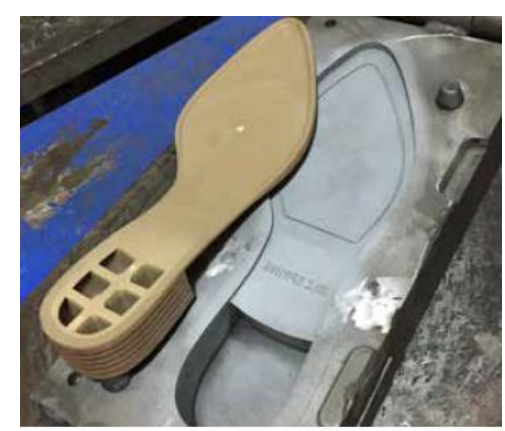

Fonte: (MOTAWI, 2018, p.92)

Outro processo de fabricação de termoplásticos ocorre via sopro, como exemplo, os airbags em TPU, aplicados em solados de tênis da marca Nike ${ }^{\circledR}$. O processo ocorre quando a máquina ejeta um tubo oco, que fica pendurado, e com duas metades de moldes na superfície exterior, que se fecham, enquanto uma agulha bombeia ar dentro do tubo. Outro método que, na verdade, pode ser uma etapa intermediária para produção de plástico, é a extrusão. Pois é onde o plástico é formulado, através da adição de aditivos e resina e misturado por ação 
mecânica e temperatura, para assim, no fim da etapa, saem em formatos de pellets, filmes, fitas ou fios. Na forma de pellets, diversos componentes de calçados serão depois injetados em formas, como: os contrafortes, biqueira e, também, peças de borracha, que passarão pelo processo de vulcanização (que dá o toque emborrachado) (MOTAWI, 2018).

Espuma de poliuretano é o exemplo mais comum de uso de plástico termofixo para sapatos. Há dois precursores em sua formulação, que serão misturados, e criarão uma ligação por processo catalítico. Ele pode ser produzido em exposição ao ar, ao qual irá expandir (como um bolo), ou fechado em molde com aquecimento, em que se ajustará à cavidade e formará uma espuma; mas uma vez moldado, não será mais reformado. Consegue-se atingir grandes densidades com esse polímero, por isso, ele é amplamente aplicado em: solado, palmilha, entressola e também em partes laterais de cabedais (MOTAWI, 2018).

\subsection{A influência dos materiais no conforto do calçado durante a marcha}

O calçado é o suporte intermediário entre o pé e o solo, sua função inclui a proteção do pé e a movimentação, além da questão estética (YICK, 2013). A grande variedade de estilos faz com que ele mude suas características, de acordo com as aplicações: em situações do dia-adia, no esporte, no lazer, em função da idade (infantil), no trabalho etc. Esses estilos elevam a complexidade do calçado, incluindo o material, custo, nível de proteção e ajuste (YICK; YU; LI, 2019).

O conforto é um atributo que influencia o usuário durante a locomoção (YICK, 2013). Há diversos fatores, que influenciam o conforto, como: impacto das forças no solo, encaixe do pé ao calçado, temperatura e umidade no ambiente interno, distribuição plantar e controle motor (BRANTHWAITE; CHOCKALINGAM; GREENHALGH, 2013; MELVIN et al., 2019; SILVA et al., 2009).

O impacto das forças no solo depende da qualidade do material do solado. Durante a primeira parte de uma caminhada, o solado é comprimido pela pressão do pé e as forças que atuam geram um trabalho no material viscoelástico do solado. Dependendo do material, a energia é armazenada ou dissipada em forma de calor e, depois que a carga é reduzida, existe a tendência que o material venha a retornar à forma original (NIGG, 2010). Por isso são aplicados em solados polímeros que tenham alto módulo elástico como borrachas vulcanizadas, além de polímeros sintéticos expandidos, ou espumas (MA et al., 2014). 
O formato do calçado e o volume da área de encaixe dos dedos são importantes para o conforto do usuário, pois quando um calçado está apertado, os dedos ficam comprimidos e podem ficar machucados. Com o uso contínuo, alguns problemas vão se agravando como desenvolver calos e, ainda, afetar a distribuição plantar (BRANTHWAITE; CHOCKALINGAM; GREENHALGH, 2013). Como solução para o encaixe, um dos materiais mais antigos que pode dar melhor modelagem ao pé é o couro bovino, ele tem a capacidade de lacear e acompanhar o contorno do pé; além dele, outras matérias primas com elasticidade, como tecidos e alguns laminados sintéticos, também têm essa capacidade em maleabilidade (WILLIAMS, 2007).

O conforto térmico é outro parâmetro, que depende muito do tipo de material empregado na parte superior, devido à transferência de calor e umidade, que influencia nas sensações do pé (YICK; YU; LI, 2019). A temperatura ideal para os pés é entre $27^{\circ} \mathrm{C}$ e $33^{\circ} \mathrm{C}$, enquanto na faixa entre $35^{\circ} \mathrm{C}$ e $38^{\circ} \mathrm{C}$ já causa irritação. A taxa de umidade pode variar dependendo da região do pé e da intensidade da atividade física (SMITH et al., 2013), por isso, é importante utilizar matérias primas que absorvem a umidade, mas que sejam também capazes de evaporar (secar) depois. A partir desses quesitos, o couro bovino também é adequado, mas, para tênis esportivos ou do dia-a-dia, é comum utilizar tecidos em malha, como o de urdume (estrutura sanduíche), por possuir bom amortecimento e transpirabilidade, devido aos seus poros (YICK; YU; LI, 2019).

A distribuição plantar é dividida em 15 áreas (Figura 38): três partes do calcanhar (13), duas partes do arco (4-5), cinco do metatarso (6-10) e cinco dos dedos (11-15) (DOMÍNGUEZ-MORALES et al., 2019). Quando há a necessidade de fazer a medição plantar, atualmente, é feita através de sensores em base rígida externa ou dentro do calçado, em momento estático e dinâmico da marcha. Uma das funções que utilizam a medição plantar é destinado para a construção de palmilhas (ZULKIFLI; LOH, 2020). 
Figura 38 - Divisão da distribuição plantar (15 áreas)

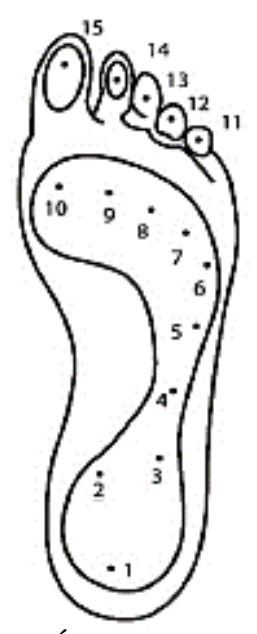

Fonte: Adaptado (DOMÍNGUEZ-MORALES et al., 2019)

A rigidez e a espessura da sola alteram a estabilidade e o equilíbrio. O suporte do calcanhar mais rígido reduz o movimento do retropé e melhora o conforto (BRANTHWAITE; CHOCKALINGAM; GREENHALGH, 2013).

No caso do calçado feminino, quando há salto alto, ele pode afetar a biomecânica da marcha, principalmente, devido ao aumento da flexão do pé, que aumenta a pressão do antepé e reduz a carga no calcanhar. Há uma discussão sobre o limite do ângulo em relação ao tamanho do salto alto e o encaixe do calcanhar (MELVIN et al., 2019). Atribui-se ao calcanhar elevado o limite de $20 \mathrm{~mm}$ uma proteção aos músculos posteriores (tríceps da perna, da tíbia e das costas), enquanto saltos acima de $45 \mathrm{~mm}$ são questionados por afetarem o equilíbrio muscular e também por causar lesões por tensão (HESSAS et al., 2018)

\subsection{Impactos Ambientais da Indústria Calçadista}

4.6.1. Ciclo de Vida de Produtos Calçadistas

Cada produto serve para um diferente propósito, tudo começa com extração de matérias primas (fase de extração) e passa para as próximas fases de produção, transporte para os pontos de venda, consumo e, finalmente, descarte. Essas séries de fases fazem parte do ciclo de vida de qualquer produto, cada fase pode causar dano ao meio ambiente. A quantificação desse impacto ambiental por ciclo de vida por produto é essencial para reduzir esses impactos (MUTHU, 2013, p.266)

Os materiais influenciam significantemente no produto do calçado, inclusive no fim da vida, na fase de descarte. Utilizam-se aproximadamente 40 tipos de materiais para se produzir um calçado. Os principais grupos são: couro, têxteis, plásticos, borrachas, mais os metais 
(STAIKOS et al., 2006). Além da variedade de materiais, as recentes mudanças na aceleração do mercado, com a intensa busca de novos consumidores, proporcionam ciclos de vida mais curtos (MUTHU, 2013; SHAH, 2018).

Para compreender os impactos ambientais, é necessário verificar o conceito da gestão do ciclo de vida. Enfatiza-se nele a gestão de negócios no campo de produtos sustentáveis, que pode também ser relacionado à indústria e ao setor de serviço. A gestão do ciclo de vida tem o objetivo de melhorar o desempenho na sustentabilidade, ao reduzir impactos ambientais e socioeconômicos, maximizando também valores sociais (SONNEMANN et al., 2015). Sua definição ainda está em construção, mas é baseada no conceito Triple Bottom Line, que integra três dimensões da sustentabilidade: econômica, ambiental e social (REMMEN; JENSEN; FRYDENDAL, 2007). Junto com Life Cycle Thinking (pensamento de ciclo de vida), que avalia o uso de recursos naturais no estágio de extração, processamento, fabricação, distribuição, uso, reciclagem reuso e disposição final (BAUMANN; TILLMAN, 2004); avaliando seu impacto no meio ambiente, economia e sociedade durante esse seu ciclo de vida (MUTHU, 2013; SONNEMANN et al., 2015).

Há uma variedade de métodos, ferramentas e programas que auxiliam para demostrar os resultados da gestão ciclo de vida. Como exemplo, segue alguns desses métodos amplamente utilizados: a Avaliação do Impacto Ambiental (EIA), usada principalmente para avaliar o impacto ambiental de um projeto e seu uso, sendo exigido por lei em algumas situações; as Contas Econômicas Ambientais (CEA), que tem como objetivo analisar a atividade econômica dentro de uma nação, em contas físicas e monetárias; a Avaliação de Ciclo de Vida (ACV), que avalia impactos ambientais e os recursos utilizados ao longo da vida de um produto (ou serviço); a Análise do Fluxo de Materiais (MFA), que se concentra na análise dos fluxos de materiais no processo de fabricação para uma avaliação e previsão de desenvolvimentos futuros e estratégias (FINNVEDEN; MOBERG, 2005 apud MUTHU, 2013).

No procedimento desses métodos apresentados anteriormente, há a inclusão de processos de auditoria para checagem de dados. Existe ainda a possibilidade de analisar somente parte dos processos produtivos, com foco nas matérias primas; na manufatura e/ou ecodesign; etapas do pós-consumo em reciclagem, reuso, obtenção de energia, etc. (SONNEMANN et al., 2015).

No tema da indústria calçadista, o método da Avaliação de Ciclo de Vida (ACV) foi utilizado para analisar os impactos dos materiais de calçados, distinguindo 4 categorias: 
Potencial de Acidificação (PA), Potencial de Eutrofização (PE), Potencial de Aquecimento Global (PAG) e Potencial de Criação de Ozônio por via Fotoquímica (PCOF) (GOTTFRIDSSON; ZHANG, 2015). Na Figura 39, demonstram-se os danos em cada categoria para cada tipo de material, na qual há um destaque ao couro, que, em todos os quesitos, causa grandes danos ao meio ambiente, seguido por plástico e borracha e, depois, têxteis, seguidos por outros.

Figura 39 - Distribuição do impacto ambiental dos principais componentes de calçado

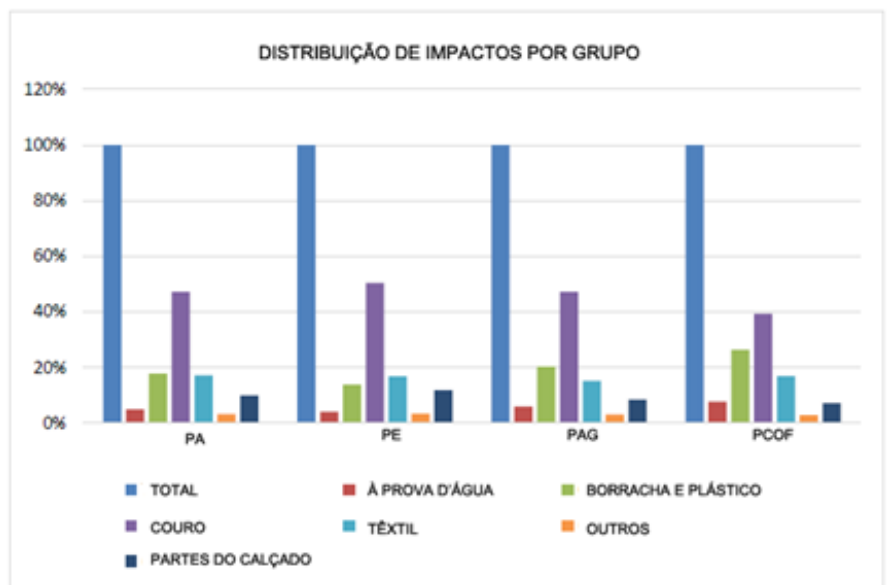

Fonte: Adaptado de (GOTTFRIDSSON; ZHANG, p.29, 2015)

Já outra pesquisa, que teve o enfoque no design, comparou a Pegada Ecológica e a Análise de Riscos Ambientais, nos estágios produtivos do calçado durante vários processos: corte (cabedal e forro), processo mecânico (montagem) e acabamento. Nessa pesquisa são comparadas duas categorias de sapatos: em cabedal de couro (vermelho e branco) e em laminado sintético (rosa e branco). Ainda sobre a Pegada Ecológica, foi analisado o gasto em energia elétrica, por não haver emissões no ar e, na Análise de Risco, envolveu um cálculo do fator de risco humano às substâncias carcinogênicas dos materiais e à exposição (área do pé, peso e em $8 \mathrm{~h}$ de uso). Como resultado, o gasto de energia para todos os tipos calçados foi de $0,75 \mathrm{kWh}$. Sobre o fator de risco, o calçado de laminado sintético rosa foi considerado o mais problemático devido à grande quantidade de compostos carcinogênicos, os ftalatos, que excederam os limiares toleráveis no forro de PVC (Quociente de Risco $=29,84$ ), diante de $\mathrm{QR}=0,57$ e 0,06 relativos ao de sintético branco e couro branco, respectivamente. Conclui-se assim, para essa pesquisa, as melhores opções eram as de calçados em couro (HERVA; ÁLVAREZ; ROCA, 2011). 
É importante observar que na pesquisa anterior, apesar do resultado apontar o calçado sintético como o maior responsável por riscos aos humanos, causados pela exposição aos compostos carcinogênicos, só chegou a essa conclusão, pelo fato do couro usado não ter sido tratado com crômio, mas com fosfônio, o que fez a diferença (HERVA; ÁLVAREZ; ROCA, 2011). Por sua vez, diversos autores compararam os impactos de diferentes tipos de calçados e destacam amplamente o aspecto negativo dos danos ambientais causados pelo couro bovino (ALBERS; CANEPA; MILLER, 2008; CHROBOT; FAIST; GUSTAVUS L., 2018; MUTHU, 2013); enquanto os danos causados por uso de tecidos ocorrem em níveis diferentes, devido à variedade de matérias primas utilizadas, como o algodão, que requer grande quantidade de água e pesticidas; assim como o uso do nylon e do poliéster têm o agravamento de que são feitos de fontes não renováveis (ALBERS; CANEPA; MILLER, 2008).

Diante dessa variedade de pesquisas, que relacionam os materiais e impactos ambientais do calçado, a fase de produção de matérias primas e da fabricação dos sapatos são responsáveis por em torno de $90 \%$ de todo impacto ambiental do todo ciclo de vida do calçado (MUTHU, 2013). Em vista disso, um relatório comparou o impacto ambiental de calçados feitos majoritariamente por materiais têxteis, sintéticos e couro (Tabela 12). Nele são mostrados esses tipos de calçados e quanto correspondem, em porcentagem, o impacto ambiental em cada categoria: alteração do clima, saúde humana, qualidade do ecossistema, recursos e retirada de água doce (CHROBOT; FAIST; GUSTAVUS L., 2018)

Tabela 12 - Impacto ambiental dos principais tipos de calçado (couro, sintético e têxteis) por categoria

\begin{tabular}{lccc}
\hline Categoria de Impacto & $\begin{array}{c}\text { Sapato de } \\
\text { Couro (\%) }\end{array}$ & $\begin{array}{c}\text { Sapato de Sintético } \\
(\mathbf{\%})\end{array}$ & $\begin{array}{c}\text { Sapato de } \\
\text { Tecido (\%) }\end{array}$ \\
\hline Alteração no Clima & $34 \%$ & $50 \%$ & $16 \%$ \\
Saúde Humana & $36 \%$ & $48 \%$ & $16 \%$ \\
Qualidade do Ecossistema & $82 \%$ & $12 \%$ & $6 \%$ \\
Recursos & $30 \%$ & $54 \%$ & $17 \%$ \\
Retirada de Água Doce & $31 \%$ & $48 \%$ & $21 \%$ \\
\hline \multicolumn{2}{c}{ Fonte: Adaptado de (CHROBOT; FAIST; GUSTAVUS L., 2018) }
\end{tabular}

Em base de todas essas considerações, pode-se verificar que o couro bovino é, de longe, o mais agressivo ao ecossistema; à saúde humana e alteração no clima; enquanto o material sintético é o maior responsável pelas consequências no uso de recursos, no caso o petróleo, seguido por consequências no clima (aquecimento global), saúde humana e uso de água doce. 
Por sua vez, os tecidos, comparados aos outros materiais, são menos nocivos ao ambiente, em todos os critérios analisados, mesmo com o uso intensivo de água no processo produtivo.

\subsubsection{Gestão de resíduos da Indústria Calçadista}

Em vista da gestão dos resíduos da indústria calçadista, foi desenvolvida, por Staikos e Ramifard (2007), uma abordagem em dois vieses, uma pró ativa e outra, reativa (Figura 40). A questão pró ativa inclui todas as medidas para minimizar o desperdício na produção por meio da substituição de materiais ou mudança no design, que faz também reduzir o dejeto de materiais na natureza, a partir da mudança do produto, seja na troca de matérias-primas, seja na alteração de processos e métodos de operação; enquanto as ações reativas concentram todas as opções de gerenciamento de resíduos (como reutilização, reciclagem, recuperação de energia de resíduos e eliminação), que atuam em resposta ao problema dos resíduos, no final da vida útil do produto (STAIKOS; RAHIMIFARD, 2007).

Figura 40 - Estrutura da gestão de resíduos da indústria calçadista

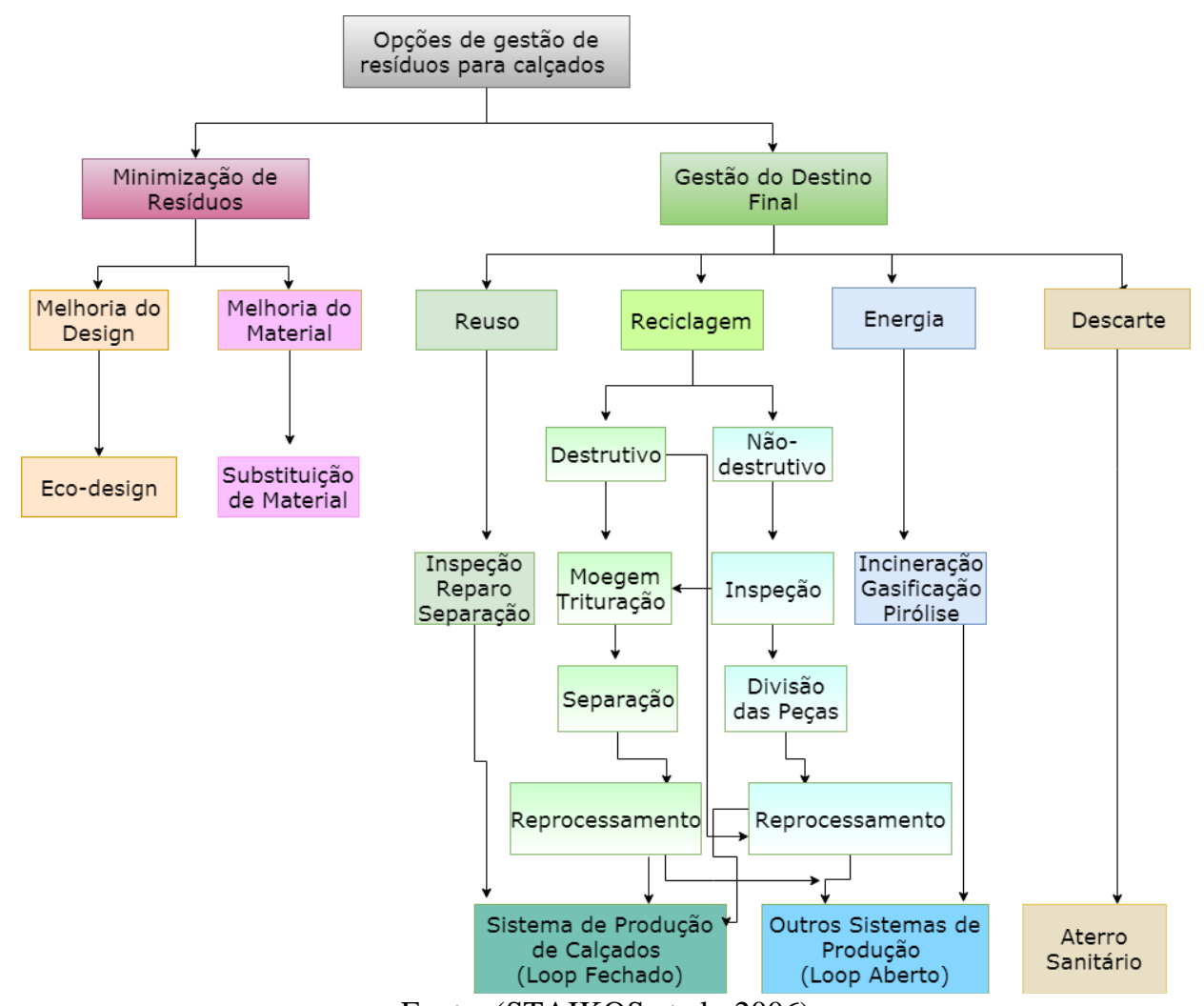

Fonte: (STAIKOS et al., 2006) 
Tendo como base, o conceito de Staikos e Ramifard (2006) (Figura 40), existem diversas pesquisas no setor de calçados, por via pró ativa, em substituição de materiais e ecodesign, como na pesquisa de redefinição do contraforte, que extinguiu o uso de adesivo e solvente (BORCHARDT et al., 2010) e no uso de método de design Fuzzy Preference Programming, integrado ao Ecodesign Index para a escolha de materiais no calçado infantil (GÁRCIA-DIÉGUEZ; HERVA; ROCA, 2015). Outras pesquisas seguem o viés nas ações reativas na gestão do descarte, como na pesquisa na Etiópia com reuso do couro bovino descartado, transformado em compósito, juntamente com plantas e resinas (TEKLAY et al., 2017). Quanto aos couros, é possível o reuso, provindo do descarte da indústria calçadista para nova costura e design de novos sapatos (OLIVEIRA; SOARES; BROEGA, 2016); assim como a reciclagem de solado de calçado com adição a resina de PU para painéis de som (YILDIZ et al., 2017) e na revisão dos tipos de tratamento da água com resíduos sólidos de curtumes com uso de oxidação, hidrólise ácida ou alcalina e enzimas (JIANG; LIU; HAN, 2016).

Outras ações reativas ocorreram, nos últimos anos, em relação às exigências internacionais sobre o mercado do couro, como consequência para um dos maiores mercados de beneficiamento do couro, na China acarretou o fechamento de cerca de 400 curtumes e, ainda, foi restringido o aumento de consumo de água, inclusive, o maior curtume do país foi obrigado a tratar o efluente (RAJAMANI, 2014). O Brasil também foi afetado, precisou reduzir o teor de sal dos efluentes, ao salgar a pele para conservação e passou a ter um maior controle na incineração do crômio. Enquanto isso, outros países passaram a investir em tecnologia no setor, a fim de solucionar o problema da poluição no efluente, como, na Índia, foi empregado cerca de USD 100 milhões na recuperação das águas; na Espanha, utiliza-se o biorreator de membrana; na Nova Zelândia, aplica-se enzimas; e a Turquia, com cerca de 540 curtumes, passou a tratar o efluente através das soluções encontradas junto às parcerias com universidades locais (RAJAMANI, 2014).

Para solucionar a reciclagem (via reativa), foram desenvolvidos equipamentos (Figura 41), que, para potencializar a eficiência deles, eram segregados por tipos de materiais predominantes (têxteis, couro ou borracha). Nos sapatos já pré-selecionados, o primeiro maquinário tritura-os e faz a separação do metal; depois, é enviado para granulação (dimensão de $5 \mathrm{~mm}$ ); e, em seguida, passa pela cascata de ar, que faz a separação, por diferença de tamanho e peso. Têxteis são mais leves que borrachas e são rapidamente retirados; enquanto separar borracha ou couro das espumas (PU, EVA), somente é possível na mesa vibratória, que depende de ajustes para ser efetiva, como: ângulo e frequência da vibração, velocidade do ar e rugosidade 
da mesa. Por fim, o experimento mostrou que é possível separar certos subconjuntos do calçado. Além do mais, avaliou-se a pureza dos materiais (em \%), resultando em calçados esportivos com sola de borracha, sendo que a borracha atingiu $80 \%$, enquanto têxteis, $65 \%$, e, espumas, 73\%. A pior situação para separação ficou para os sapatos, feitos em couro, e borrachas expandidas, uma vez que as densidades eram parecidas; assim elas atingiram apenas $58 \%$ de pureza (LEE; RAHIMIFARD, 2012).

Figura 41- Fluxo de Reciclagem do Calçado

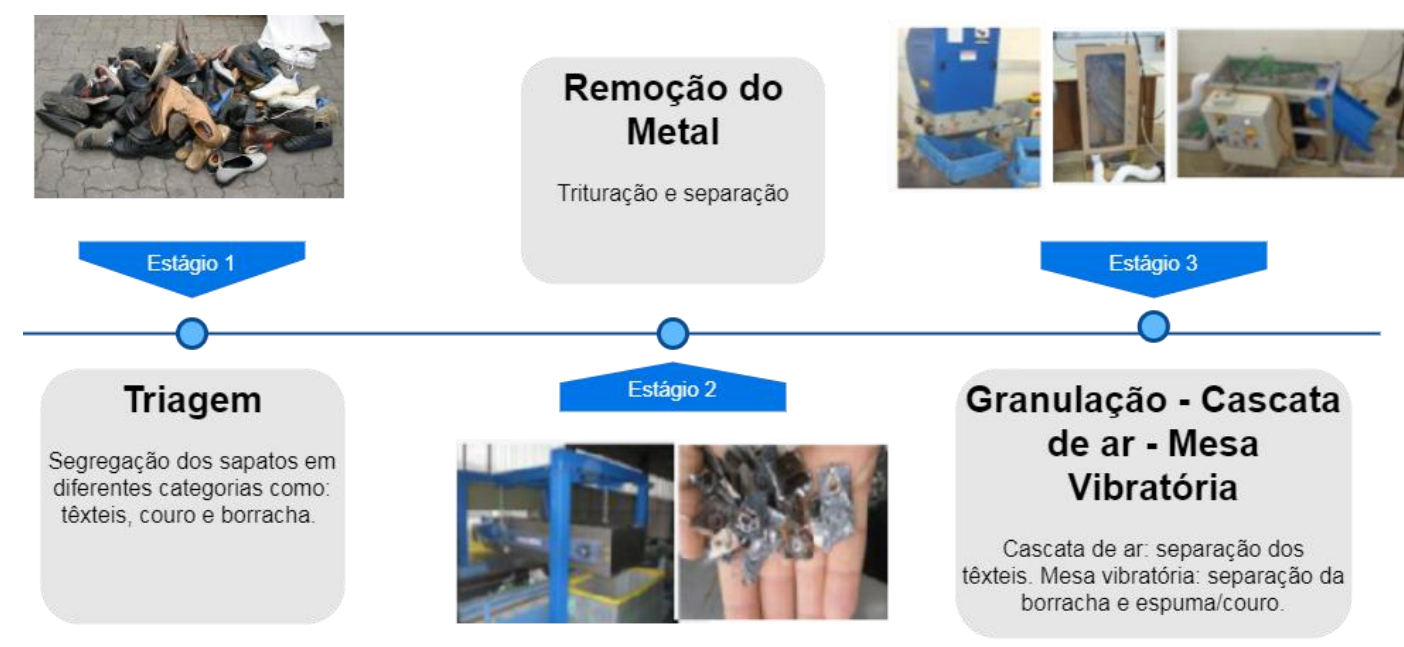

Fonte: Adaptado de (LEE; RAHIMIFARD, 2012)

Os autores da pesquisa anterior sobre maquinário para reciclagem apontam as possíveis soluções de aplicabilidade das matérias primas, após a separação. Sugerem a utilização do couro como fertilizante, após eliminação do crômio ou em composto para vedação acústica, assim como da borracha, para recobrimento de superfícies de produtos em tapetes e convés de madeira (LEE; RAHIMIFARD, 2012). Nesse sentido, a marca esportiva $\mathrm{Nike}^{\circledR}$ já faz a reciclagem dos têxteis, borrachas, além de espumas comercializar produtos semelhantes em laminado aglomerado (compósitos) para revestimentos de parquinhos infantis e academia, grama sintética e mantas para revestimento de piso (NIKE, 2019).

Outra saída, via ação reativa, é a obtenção de energia, comum em tratamentos térmicos para os resíduos industriais. Incineração envolve a destruição dos resíduos, a partir de multicâmeras em série, com o aproveitamento do calor e geração de energia (VAN RENSBURG; NKOMO; MKHIZE, 2020). No processo, há dois tipos de combustão: a primária, que faz a gaseificação; e a secundária (oxidação dos hidrocarbonetos e gases combustíveis), em que ocorre a retirada das cinzas e os gases são resfriados. Após essa etapa, 
são neutralizados os gases ácidos, e o restante é liberado na chaminé, que devem seguir os padrões de emissão de cada país (BREDA, 2016). A autora apontou a visita à uma planta com capacidade de processamento de $250 \mathrm{~kg} / \mathrm{h}$.

No processo de pirólise, a obtenção de energia (ação reativa) ocorre pela transformação e recuperação dos resíduos em tratamento térmico por volatilização. Autores já indicam a possibilidade de utilizar esse método para processar os materiais de calçados, como borrachas, plásticos e resíduos orgânicos (VAN RENSBURG; NKOMO; MKHIZE, 2020). No estudo da pirólise do couro bovino, conseguiu-se extrair gás combustível, cinzas carbonatadas residuais e oleosas, contendo crômio trivalente, mas, não chegou-se a utilizar o couro do pós consumo, que poderia ter outros compostos juntos (SETHURAMAN; SRINIVAS; SEKARAN, 2013; VAN RENSBURG; NKOMO; MKHIZE, 2020).

Enquanto na abordagem pró ativa, mudanças ocorridas a partir do design, muitas vezes, alteram os processos na concepção do produto, como na fabricação digital. Por esse método, scanners captam as imagens do formato do pé em três dimensões (3D), esteiras identificam os pontos de apoios na parte inferior do pé (Figura 38, item 4.5), em posições estáticas e dinâmicas, aliados à programas computacionais de desenhos em 3D para simulação e impressora 3D permitem um processo de desenvolvimento de produto individualizado. Muitas vezes, esses métodos são utilizados para desenvolvimento de palmilhas e partes de componentes do solado, que têm sido principalmente aplicados em linha de ortopédicos (CHATZISTERGOS et al., 2020; KLIMIEC et al., 2017). Mesmo assim, segmentos esportivos, femininos e outros vêm sendo estudados com processos produtivos semelhantes para solados personalizados (AMORIM; NACHTIGALL; ALONSO, 2019; AMZA; ZAPCIU; POPESCU, 2019; NACHTIGALL et al., 2018).

Por fim, o foco desta pesquisa é o aprofundamento das informações de como o Brasil está pondo em prática as saídas sugeridas, por todo o mundo, na gestão de resíduos do setor calçadista (via ações pró ativas e reativas). Percebe-se que, ainda, essas ações são isoladas e que, normalmente, no país, relacionam-se com o termo da sustentabilidade, como será descrito a seguir. 
4.6.3. A relação do setor calçadista brasileiro e a sustentabilidade

Ações brasileiras na sustentabilidade estão presentes no segmento calçadista, principalmente, apoiadas pelas associações nacionais de classes dos calçados - Abicalçados (Associação Brasileira de Indústrias Calçadistas) e - de componentes - Assintecal (Associação Brasileira de Empresas de Componentes para Couro, Calçados e Artefatos). Elas promovem feiras nacionais e internacionais, projetos tecnológicos, incentivo à exportação, assessorias, aproximação de fornecedores e clientes da cadeia, certificação, dados estatísticos etc. (ABICALÇADOS, [s.d.]; ASSINTECAL, [s.d.]).

Um evento com grande importância latino americano é o Inspiramais, uma feira que ocorre duas vezes ao ano na cidade de São Paulo, com cerca de 190 expositores e 7,8 mil visitantes qualificados, dados do último evento (em janeiro de 2020), que contou com os empresários do segmento calçadista, confecção e moveleiro, estilistas, designers e formadores de opinião. No salão, ocorreram principalmente exposições de materiais, mais de 1000 unidades deles são organizados em um espaço, para apresentação das tendências de moda e cores da estação (Figura 42a). Além disso, palestras, projetos e diversos stands de marcas de fornecedores de matérias primas participam do evento, os stands são ambientes para aproximar clientes e empresas para conhecer os lançamentos dos produtos (INSPIRAMAIS, 2020).

Figura 42 - Feira Inspiramais - (a) Materiais expostos - jan2019, (b) Palmilha de espuma reciclada (Ciclomade) - jun 2019, (c) - Tecidos naturais - jun 2019

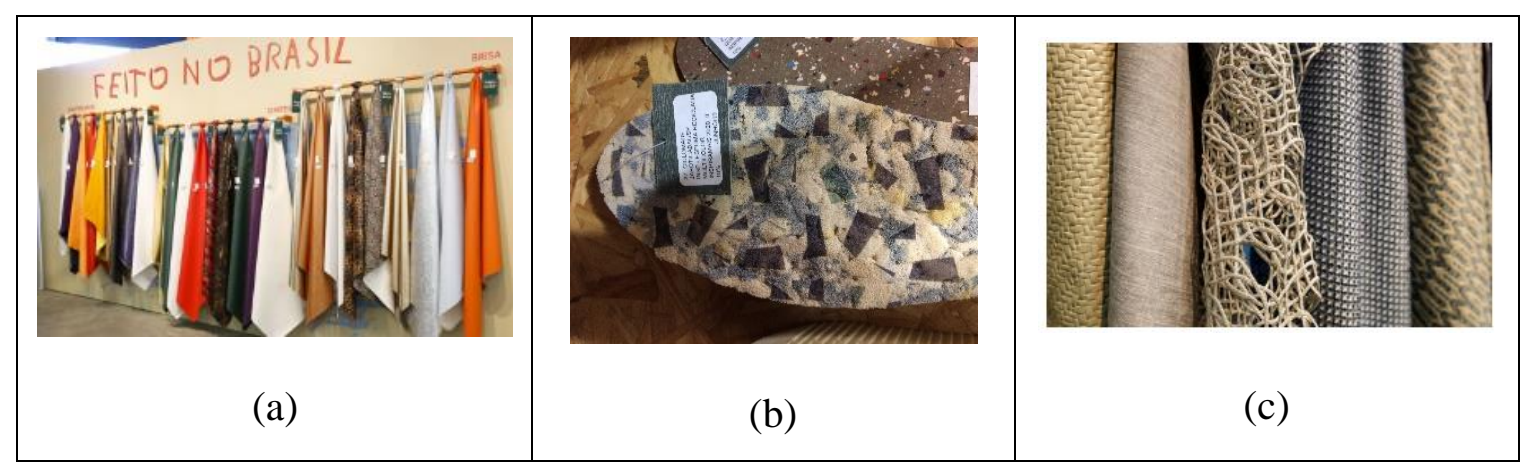

Fonte: (a) (b) (c) (INSPIRAMAIS, 2020)

Um dos projetos com destaque da feira Inspiramais é o Espaço da Sustentabilidade, que "estimula e dá visibilidade a produtos e empresas que acreditam na sustentabilidade como fator diferencial de competitividade" (INSPIRAMAIS, 2019). Esse espaço, os produtos são interessantes porque foram desenvolvidos com assessoria de uma designer (da Assintecal), 
junto com as empresas participantes (Figura 42b e c) (INSPIRAMAIS, 2019). A principal abordagem no desenvolvimento dos produtos tem como base na ação pró ativa por substituição de matéria prima e melhoria de processos no design.

De acordo com as regras de participantes do evento, há uma variedade de tipos de fornecedores do calçado, representando uma grande variedade de componentes. A partir disso, os materiais desenvolvidos variam desde compostos químicos, como o pigmento fluorescente EZ-17 (atóxico, sem formaldeído e de alta performance) da empresa Braschemical (http://braschemical.com.br/), voltados para formulação de laminados, até componentes lançados que estão prontos serem utilizados na fabricação dos sapatos. Dentre os lançamentos, tiveram destaque alguns produtos: um tecido da indústria têxtil brasileira ITM (https://itmtextil.com.br/br/home/) em fios de algodão reciclado com tingimento natural (linha Eco Fio), um compósito à base de couro reciclado (MK Química/Solus) e o biopolímero derivado do milho, da empresa Cofrag (https://www.cofrag.com.br/empresa/), com características similares às do poliéster (INSPIRAMAIS, 2019).

O local da feira Inspiramais, por reunir os principais fabricantes de componentes do calçado nacional, permite que os profissionais de criação das marcas de fabricantes de calçado circulem no evento, tornando-o em um local de interesse para obtenção de informações para esta pesquisa, através da observação produtos exibidos, da realização de entrevistas e de conhecimento de grande parte das empresas do setor. Nesse ponto, é importante ressaltar que o foco dessa coleta de informações foi identificar se os produtos sustentáveis eram somente desenvolvidos para o fórum de tendência do evento, ou se eles já pertenciam à linha comercial das empresas.

Uma certificação, promovida pela Assintecal e Abicalçados, é o selo Origem Sustentável, criado em 2013, que é vinculado à toda cadeia da indústria calçadista brasileira, dentre eles, produtores e revendedores de componentes, calçados ou artefatos. O selo inclui a avaliação de indicadores econômicos, ambientais, sociais e culturais. A partir desses indicadores, as empresas são auditadas para se elencar os itens atendidos e é feito uma classificação. Como resultado, é obtido a certificação, de acordo com os níveis atingidos, nomeados em ordem decrescente: em ouro, prata, diamante e bronze (CARVALHO et al., 2014).

Infelizmente, há pouca informação documentada sobre como foram realizadas as métricas para o desenvolvimento e a aplicação do selo Origem Sustentável em casos práticos. Deste modo, no presente estudo, houve o interesse de identificar as vantagens obtidas pelas 
empresas que o implantaram a respeito do indicador ambiental, como: dados concretos sobre resíduos; redução de insumos; ações em logística reversa; soluções ambientalmente mais correta em relação aos resíduos não recicláveis etc. Essa coleta de informações também abrangeu a verificação de quais ações internas foram feitas pelas empresas, em conjunto com os funcionários, para se implantar o selo e, na identificação das vantagens competitivas de mercado, verificar se houve avanços no campo da exportação.

A respeito da situação da gestão dos resíduos sólidos no Brasil, é importante destacar, em 2010, houve a promulgação da Lei no 12.305/10, que instituiu a Política Nacional de Resíduos Sólidos - PNRS. Sobre ela, há objetivos de "não geração, redução, reutilização, reciclagem e tratamento dos resíduos sólidos, bem como disposição final ambientalmente adequada dos rejeitos" (BRASIL, 2017, p.13). A mesma lei ainda apresenta diversos princípios como: a prevenção e a precaução, o poluidor-pagador, a responsabilidade compartilhada pelo ciclo de vida dos produtos, a visão sistêmica na gestão de resíduos sólidos (ambiental, social, cultural, econômica, tecnológica e de saúde pública) (BRASIL, 2017; LOSCHIAVO DOS SANTOS; VILLAC, 2019).

Apesar da importância desse marco no Brasil, com a implantação da PNRS, estima-se que essa lei já nascia atrasada na questão da regulamentação da gestão de resíduos, em relação a outros países, como Estados Unidos e Alemanha, que já tinham desenvolvido leis nesse sentido, cerca de quatro décadas antes. Também é apontado o impacto da PNRS para a cadeia calçadista, em se que determinou que cada ator da cadeia (produtor, distribuidor e consumidor) passa a ser corresponsável pelo ciclo de vida e poluidor-pagador dos resíduos gerados. $\mathrm{O}$ atraso do país também é visto nas metas, pois se previa, até 2015, a eliminação de $50 \%$ da destinação inadequada e, até 2019, deveria ter sido feito a destinação de 100\% de resíduos industrial de maneira correta ambientalmente. Além do mais, existem críticas sobre a pouca implementação logística reversa no país, sendo que o seu conceito, pela PNRS, é relacionado às ações de restituição dos resíduos sólidos para o reaproveitamento em seu ciclo produtivo ou em outros, considerando a destinação final ambientalmente adequada (BRASIL, 2017; BREDA, 2016).

Seguindo a temática da logística reversa, uma pesquisa apresentou o problema da separação do lixo de um polo calçadista. Ela foi feita com 104 empresas, no polo de Franca (2015), contendo 87,18\% de fabricantes de calçados e, o restante, de fornecedores de matéria prima. A partir dos dados coletados junto às empresas, a pesquisa verificou a destinação dos resíduos industriais. Identificou-se que não houvera a separação criteriosa do lixo e nem mesmo a separação de materiais recicláveis. Quando foram questionadas, as empresas não conseguiram 
dar uma explicação convincente para o problema: uma vez que justificaram a falta de separação do lixo era devido à forma de destinação, pois, no final, tudo era direcionado aos aterros (BREDA, 2016).

Na pesquisa anterior, também foi mostrado a quantidade dos resíduos gerados pela empresa, por par de calçado, e o custo gasto com o lixo. Os valores resultantes foram mostrados a partir da média de rejeitos, por par, contabilizado em 168,6g, e a estimativa de custo do resíduo, por par produzido, resultou no valor médio de R\$0,0584 (BREDA, 2016).

Apesar desse problema regional de Franca, estudos indicam que o sindicado local vem se envolvendo para encontrar melhores soluções na gestão de resíduos (ação reativa), inclusive, há relatos de que a entidade participou de estudos de conhecimento do processo de coprocessamento para verificar a viabilidade técnica e financeira. Assim, a ideia era utilizar o resíduo do calçado de couro como fonte de energia, na indústria de cimento Portland, conforme já acontece no polo de calçados do sul do Brasil, na utilização das sobras de couro (BREDA, 2016).

Outra ação no campo da logística reversa é na reutilização de resíduos, em que é relacionado à ação reativa, segundo a teoria de Staikos e Ramifard (2006). Um exemplo de reuso é comprovado por meio de um estudo de caso para o setor de produtos de uma empresa fabricante de sapatos infantis do Rio Grande do Sul, de grande porte, que produz 15 mil pares/dia. Como resultado, a empresa apontou ações em que o reuso é feito a partir de peças de couro e com duas formas de reaplica-las: uma por desenvolvimento de modelos especiais de calçados para reaproveitamento das peças cortadas, e outra forma, para confecção de enfeites das menores peças, mas que demanda muito tempo, devido ao trabalho manual. Essa ação já trouxe vantagens significativas, verificou-se que tais práticas reduziram esses rejeitos em 15\%, por semana e, no mês, significou a redução de descarte de cerca $21 \mathrm{~kg}$ de couro (ASHTON, 2018).

No outro viés de gestão de resíduos, o do pró ativo, com foco no design, outra pesquisa utilizou scanners (do CTI Renato Archer, Campinas), tapete com sensores (baropodometria) e impressão 3D para fazer um projeto de calçado, que representasse o tamanho médio do pé feminino brasileiro. Assim, foi definido o tamanho 36 (tamanho muito vendido no mercado nacional) e, depois, desenvolvido um sapato de salto $9 \mathrm{~cm}$, em modelo Anabela, procurando aumentar a área de contato para diminuir os picos de pressão e dar mais estabilidade. $O$ processo 
também envolveu análise de desempenho, por simulações, ao medir a dissipação de energia do impacto da passada e por forças atuantes (SILVA, 2016).

Por fim, passados dez anos da criação da PNRS, a coleta seletiva ainda é precária no país, cerca de 55\% das cidades não criaram um plano municipal sólido do lixo. Por sua vez, o foco das empresas é sempre limitado ao crescimento econômico, deixando de lado ações como de educação ambiental; tudo isso é agravado pelo educação ambiental é pouco desenvolvida e, ainda com o momento crítico na política, freia o avanço e revela-se a crise ética e de responsabilidade humana sobre o futuro (LOSCHIAVO DOS SANTOS; VILLAC, 2019)

Sobre as soluções apresentadas da gestão de resíduos das indústrias calçadistas brasileiras, obtiveram-se exemplos diversos nas diferentes modalidades em: ações reativas, como reinserção de resíduos no processo e coprocessamento; ações proativas, como ocorrem, no evento Inspiramais, no desenvolvimento de produtos mais sustentáveis, ou redução de etapas de design por escaneamento e impressão 3D e; ainda, ações mais globais, como a implementação do selo Origem Sustentável. No entanto, todas essas soluções são esparsas e isto será confirmado com maior detalhamento neste estudo. Especificamente, na fase reativa, após o ciclo de vida dos calçados, supõe-se que há a maior inação, em relação a encontrar opções em logística reversa ou destinação adequada, por parte dos agentes da cadeia calçadista (indústrias calçadistas e intermediários), governo, população e outros atores envolvidos. 


\section{METODOLOGIA}

Para desenvolver as etapas da pesquisa, baseou-se no objetivo geral e nos específicos, desenvolvidos a partir da teoria de gestão de resíduos por Staikos Ramifard (2007). O processo metodológico envolveu, primeiramente, a busca de documentação indireta, a partir de fontes secundárias, em artigos científicos em plataformas como Google Acadêmico, Scopus e Web of Science, a partir de palavras chaves "footwear production", "biomechanics", "materials", "life cicle management" e "footwear waste". A busca de fontes primárias foi feita, através de relatórios setoriais sobre a produção calçadista brasileira e mundial, complementaram as informações para revisão de literatura.

Outras formas de coletas diretas ocorreram por meio das pesquisas de campo para busca de informações em empresas de componentes, via pesquisa qualitativa, através de entrevistas exploratórias (na primeira e segunda fase) (Figura 43). Coletas diretas em sites de empresas e observação não participativa, em feiras e palestras, complementaram os dados da pesquisa qualitativa. Além de um experimento laboratorial, de caráter quantitativo, a fim de reproduzir o processamento da produção de solado, com a adição de um aditivo biodegradável, serragem de bambu (Figura 43).

Figura 43 - Metodologia de pesquisa: pesquisa exploratória e pesquisa laboratorial, fases e objetivos de cada etapa.

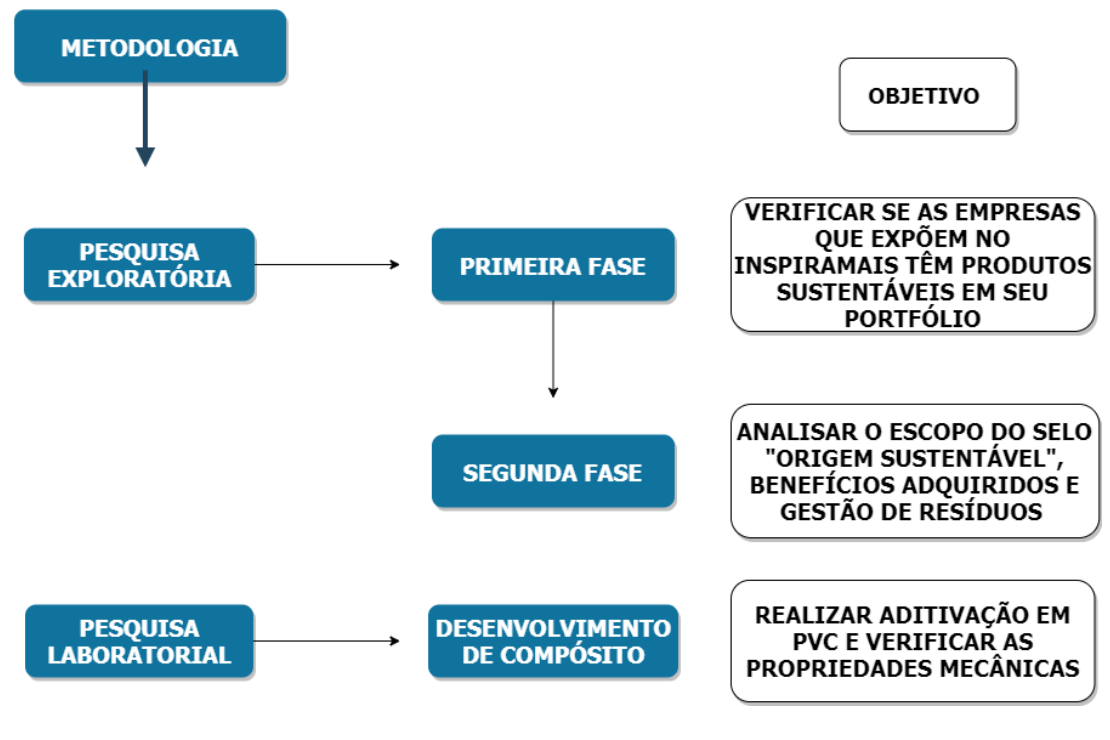

Fonte: (Lais Kohan, 2020)

Na primeira fase, foram realizadas 5 entrevistas exploratórias, três, na feira Inspiramais (Empresas A, B e C), e, duas, dentro de indústrias (Empresa D e F), para verificar se essas 
empresas já efetivaram a produção de produtos sustentáveis (em base natural, fontes recicladas, bio aditivos, entre outros) ou se realizam práticas de gestão de resíduos dentro das empresas. Além disso, para se ter uma visão mais global das empresas participantes da feira, ampliou-se a pesquisa, através do site dos expositores específicos do calçado (em um total de 182), dentre elas 116 são empresas fornecedoras de produtos de componentes.

Após essa etapa, houve a segunda fase com mais três entrevistas, tendo como foco o selo nacional "Origem Sustentável”. Uma entrevista foi realizada com a responsável do selo, pertencente ao Instituto by Brazil e, outras duas com indústrias para verificar as vantagens da obtenção do selo. Para complementar essas informações, foi documentado parte de uma palestra sobre o selo, com o título "Sustentabilidade: é hora de avançar".

Além das entrevistas, um teste laboratorial de caráter quantitativo foi feito com o objetivo de conhecer o processamento de solados na indústria, só que adaptado para escala laboratorial e introduzido um aditivo em fibras vegetais.

A seguir, serão apresentados os detalhes das duas fases de pesquisa qualitativa e o processo realizado para o teste laboratorial.

\subsection{Pesquisa Qualitativa}

\subsubsection{Pesquisa Exploratória}

A utilização de questionário semiestruturado, com perguntas abertas, foi direcionado a partir de um protocolo de pesquisa, que é composto com as principais temáticas e contém os subtemas que se pretendia atingir nas respostas. Com isso, o protocolo de pesquisa foi desenvolvido com o objetivo de aumentar a confiabilidade da pesquisa e orientar o investigador na realização da coleta de dados (YIN, 2010).

Muitas empresas optaram por não serem identificadas, e por esse motivo, foram denominadas de empresa 'A', 'B', 'C', 'D', 'E' e 'F'. As empresas das quais se citam os nomes autorizaram sua divulgação. Em todos os casos houve a permissão da divulgação dos dados apresentados neste estudo.

As empresas selecionadas para entrevistas seguem a classificação quanto ao seu porte, de acordo com o critério do IBGE, pelo número de empregados (IBGE, 2013). Segue abaixo a configuração da classificação: 
Tabela 13 - Classificação do Porte das Empresas Brasileiras (IBGE)

\begin{tabular}{lc}
\hline Porte & Número de Empregados \\
\hline Micro & Até 19 \\
Pequena & $20-99$ \\
Média & $100-499$ \\
Grande & Acima de 500 \\
\hline
\end{tabular}

O Quadro 6 contém apresentadas todas as entrevistas, realizadas na pesquisa, de acordo com a data, nome, segmento, porte, tipo e local de coleta. Na primeira fase (em cinza), aparecem as três entrevistas na feira Inspiramais feitas com gestores de produto das indústrias ou da equipe comercial, o questionário encontra-se no Apêndice A (Empresas A, B e C), o roteiro no Apêndice B (Empresa D) e o resultado da entrevista resumida Apêndice C (Empresa E). A

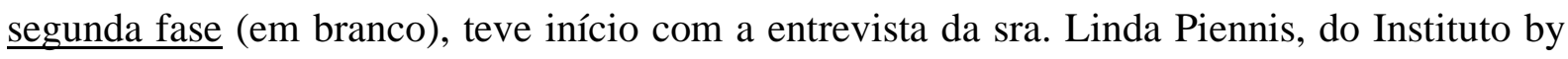
Brazil (IBB), no Apêndice D (entrevista); e, as empresas Cipatex, Apêndice E (entrevista) e Empresa F, no Apêndice F (entrevista). As entrevistas ocorreram em função da representatividade das empresas no setor (em base de seleção prévia) e da disponibilidade (aceitação das empresas selecionadas em concederem as entrevistas).

Quadro 6 - Informação da coleta de dados das entrevistas (data, segmento, porte, tipo e local da coleta)

\begin{tabular}{llllll}
\hline Data & Empresa & Segmento & Porte & Forma de coleta & Local da coleta \\
\hline 15/01/2019 & A & Solados de EVA & Média & Pessoal & Inspiramais (São Paulo - SP) \\
15/01/2019 & B & Tecidos & Pequena & Pessoal & Inspiramais (São Paulo - SP) \\
15/01/2019 & C & Contraforte & Média & Pessoal & Inspiramais (São Paulo - SP) \\
$17 / 02 / 2019$ & D & Tecidos & Média & Pessoal & Indústria (Interior - SP) \\
$13 / 11 / 2019$ & E & Solados de PVC & Média & Pessoal & Indústria (São Leopoldo - RS) \\
$13 / 11 / 2019$ & IBB & Associação & Pequena & Pessoal & Escritório (Novo Hamburgo - RS) \\
$02 / 12 / 2019$ & F & Indústria de Calçados & Grande & Telefone & \\
$10 / 10 / 2019$ & Cipatex & Laminados Sintéticos & Grande & Pessoal & Na indústria (Cerquilho - SP) \\
\hline
\end{tabular}

Fonte: (Lais Kohan, 2020)

5.1.2. Outras formas de coleta de dados por forma direta

Para complementar a primeira fase, foram consultados, no site da feira Inspiramais, todos os fornecedores participantes e suas páginas virtuais, no período entre 24 e 31 de julho de 2020, referente aos fornecedores que participaram do último evento, em janeiro de 2020. 
$\mathrm{Na}$ segunda fase, houve também um complemento de informações, a partir de dados coletados na palestra, com o título "Sustentabilidade: é hora de avançar", através de anotações e fotos do evento obteve-se dados complementares sobre as dimensões do selo e as vantagens obtidas por algumas empresas. O evento ocorreu na cidade de Campo Bom, no Rio Grande do Sul, no dia 13 de novembro de 2019.

\subsection{Pesquisa Quantitativa}

\subsubsection{Pesquisa Laboratorial}

Para realização da pesquisa laboratorial foram realizadas duas etapas para o desenvolvimento do teste prático (Figura 44). A primeira etapa foi feita em grupo, com embasamento teórico e químico, a partir dos conhecimentos adquiridos na disciplina de Processamento de Termoplástico (Unifesp). Nela, houve diversas etapas para conhecer o PVC e o processamento para a realização do teste prático: imersão em literatura, feiras de plásticos (insumos, maquinários e processamento), escolha da formulação e teste prático na Plataforma Multiusuária Processamento de Materiais Poliméricos da Unifesp, Diadema - SP. Na segunda etapa, já individualmente, foi aprofundado a literatura científica a fim de identificar melhoria de tratamento de fibras vegetais (serragem de bambu) e compatibilidade com o PVC; em seguida, foi feito o processamento do material e os testes mecânicos para avaliar o material desenvolvido.

Figura 44 - Fluxograma das etapas desenvolvidas

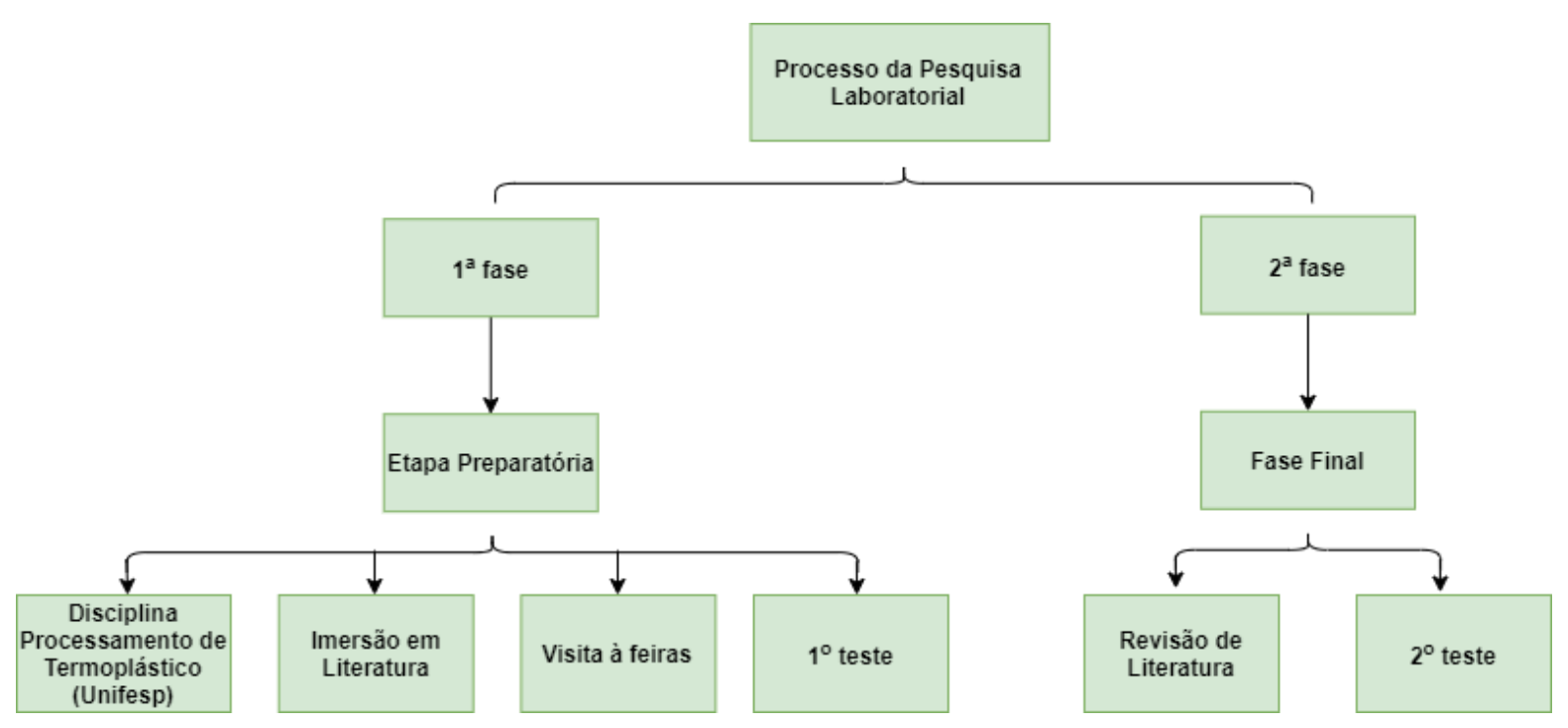

Fonte: (Lais Kohan, 2020) 
5.2.2. Instalações para realização dos experimentos de preparação das fibras, processamento, caracterização da fibra e caracterização do compósito.

Os ensaios de preparação da serragem de bambu e o processamento do compósito foram realizados em:

- Laboratório de Engenharia e Controle Ambiental (LENCA) da Unifesp (Diadema - SP) - balança de precisão, peneiras, mesa de aquecimento, estufa termo circuladora, agitador magnético, gotejador, agitador mecânico.

- Plataforma Multiusuária de Processamento de Materiais Poliméricos da Unifesp (PMPMPOL) (Diadema - SP) - prensa mecânica, prensa automática e calandra.

Os ensaios de caracterização de serragem de bambu e do compósito PVC-serragem foram realizados em:

- Laboratório de análises têxteis da empresa Golden Technology (São José dos Campos - SP) - FTIR da serragem de bambu

- Laboratório de caracterização de fibras têxteis da Universidade do Minho (UMINHO) (Guimarães - Portugal) - DSC e TGA da serragem de bambu

- Laboratório de Fibras Têxteis da Escola de Artes, Ciências e Humanidades da Universidade de São Paulo (EACH-USP) (São Paulo - SP) - ensaios tênseis das fibras;

- Laboratório de polímeros biodegradáveis e ambientalmente amigáveis da Universidade Federal do ABC (UFABC) (Santo André - SP) - fratura criogênica

- Laboratório Multiusuário de Nanociências e Nanotecnologia (LABNANO) do Centro Brasileiro de Pesquisas Físicas (CBPF) (Rio de Janeiro - RJ) - análises de MEV do compósito.

\subsubsection{Etapas do desenvolvimento do compósito}

Como apresentado no item anterior, houve alguns passos, antes, para fazer o teste laboratorial. Essa etapa, especificamente, de laboratório, será mostrada a seguir e o material desenvolvido é um compósito. Um compósito é combinação de dois materiais, em que um deles é chamado de fase de reforço (ou carga), que é composto por fibras, nesse caso, camadas ou partículas, elas 
são impregnadas em outros materiais, chamados matriz (metal, cerâmica ou polímero) (ELANCHEZHIAN et al., 2018; PICKERING; EFENDY; LE, 2016).

No processo de experimentos laboratoriais, utilizam-se critérios de segurança, calibração e controle de experimentos para assegurar que os processos estejam adequados e não influenciem nos resultados. O que contribui para os controles dos experimentos são os padrões de referências dos materiais, como fichas técnicas dos fornecedores de matéria prima, para base de informação (HARRIS, 2007); além de artigos científicos, no caso do compósito desta pesquisa, que auxiliaram para determinação de métodos de tratamentos das fibras e desenvolvimento de compósito de PVC em base de uma matriz fornecida como produto de mercado já pronto.

Na Figura 45, é mostrada as etapas para o desenvolvimento do compósito, partir de: recebimento das matérias primas, limpeza das fibras (peneiramento, secagem e tratamento), mistura, conformação do compósito (prensa) e testes mecânicos e morfológicos para interpretação dos resultados. É importante registrar que em cada etapa da pesquisa foi feita a documentação, por meio de fotos e anotações durante o processo.

Figura 45 - Etapas de desenvolvimento do compósito

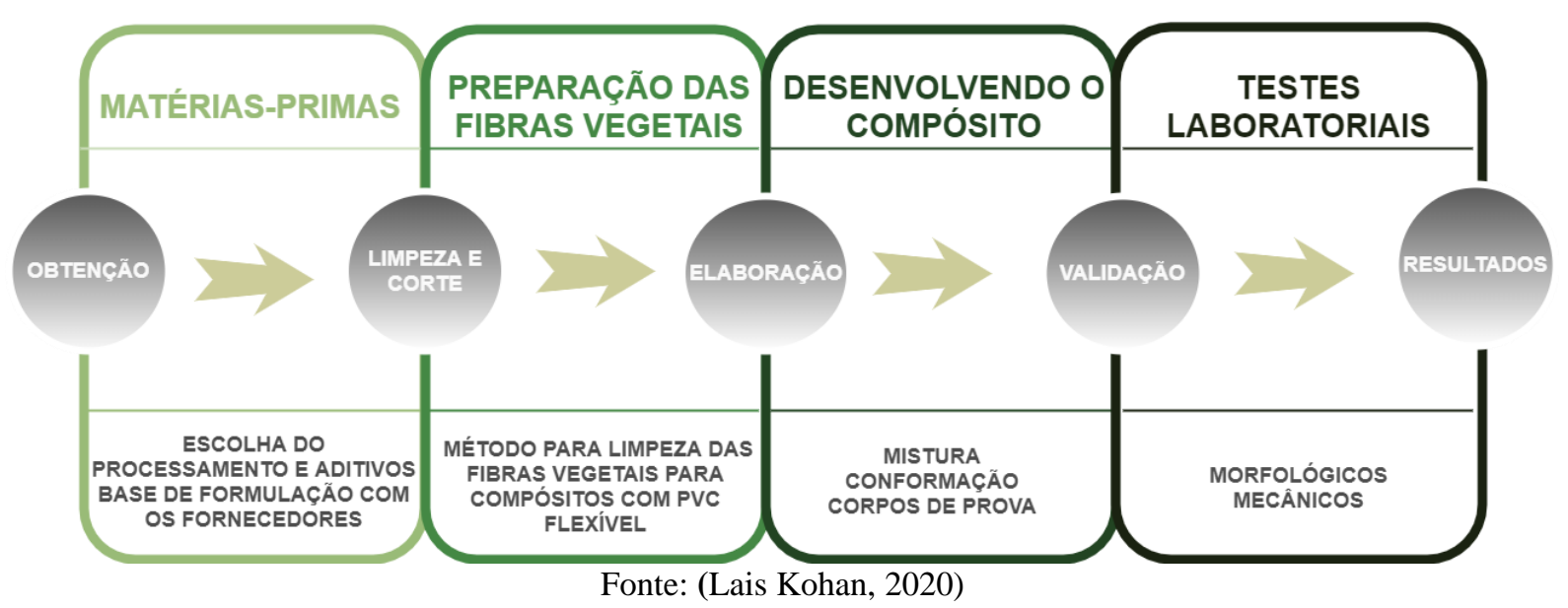

5.2.3. Insumos utilizados na pesquisa

5.2.3.1. Serragem de bambu

A serragem de bambu da espécie Dendrocalamus giganteus foi obtida por meio de doação do sr. Pedro Karam que comercializa ripas para montagens eventos (em São 
Paulo Capital), o que caracteriza esse material como um resíduo de sua produção. O bambu havia sido comprado por ele do sítio Samaúna, cidade de Registro-SP.

Figura 46 - Amostra de serragem de bambu sem tratamento

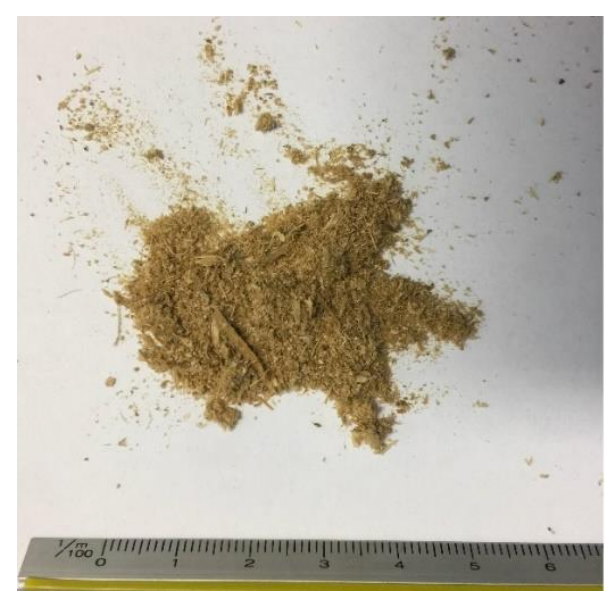

Fonte: (Lais Kohan, 2020)

\subsubsection{Composto de PVC}

O PVC utilizado na pesquisa laboratorial foi um composto granulado, recebido por meio de doação da empresa Karina ind. Com. Plásticos (Figura 47). Esta empresa é líder do mercado nacional em composto de PVC e está no segmento há mais de 40 anos (KARINA, [s.d.]).

Figura 47 - Composto de PVC flexível da empresa Karina

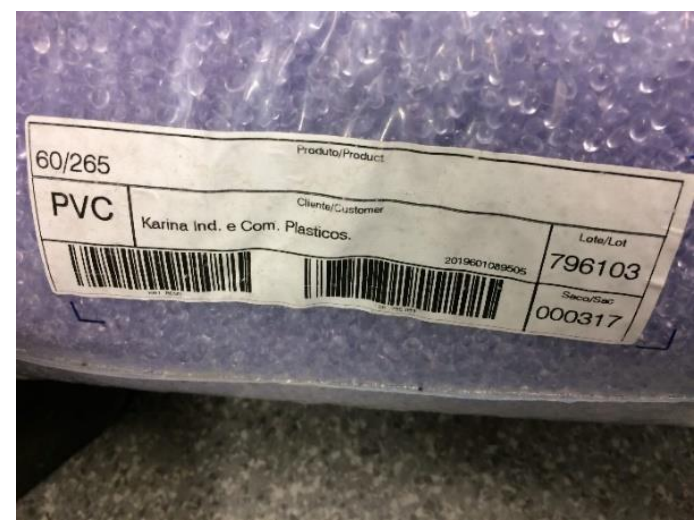

Fonte: (Lais Kohan, 2020)

O composto de PVC é uma formulação pronta, já com resinas e aditivos. O formato em grânulos é característica dos compostos flexíveis, enquanto mais rígidos, normalmente, são fornecidos em pó (chamados como dry blend). O composto granulado é indicado para 
desenvolver os produtos com alimentação em injeção ou na extrusão com rosca simples (RODOLFO JUNIOR; TSUKAMOTO, 2019).

A base da formulação foi informada pela empresa que contém: resina K65 da Braskem, éster disopentílico de ácido ftálico (DIPP), óleo de soja epoxidado, ácido esteárico, estabilizante térmico (bário e zinco). O composto tem as características em dureza Shore A 65 (Teste de Dureza conforme norma ASTM D2240) e densidade 22.

\subsubsection{Produtos químicos utilizados}

- Merceirização: utilização $\mathrm{NaOH}$ da marca Vetec (P.A.) - Química Fina, com descrição de "Hidróxido de Sódio lentilhas 99\%".

- Tratamento com silano:

- Silano da marca Dow-Corning® Z-6011, pureza de 98\%, caracterizado como um aminopropiltrietoxisilano (Figura 48a).

- Etanol da marca Synth®, descrito pelo fabricante como Álcool Etílico Absoluto 99,5\% (Figura 48b).

- Ácido Acético Glacial $\left(\mathrm{CH}_{3} \mathrm{COOH}\right)$ da marca Synth® (P.A.) (Figura 48c).

Figura 48 - Produtos químicos utilizados na segunda fase do experimento. (a) Silano Z60-11 da marca Dow-Corning® (b) Etanol da marca Synth® (c) Ácido Acético da marca Synth®.

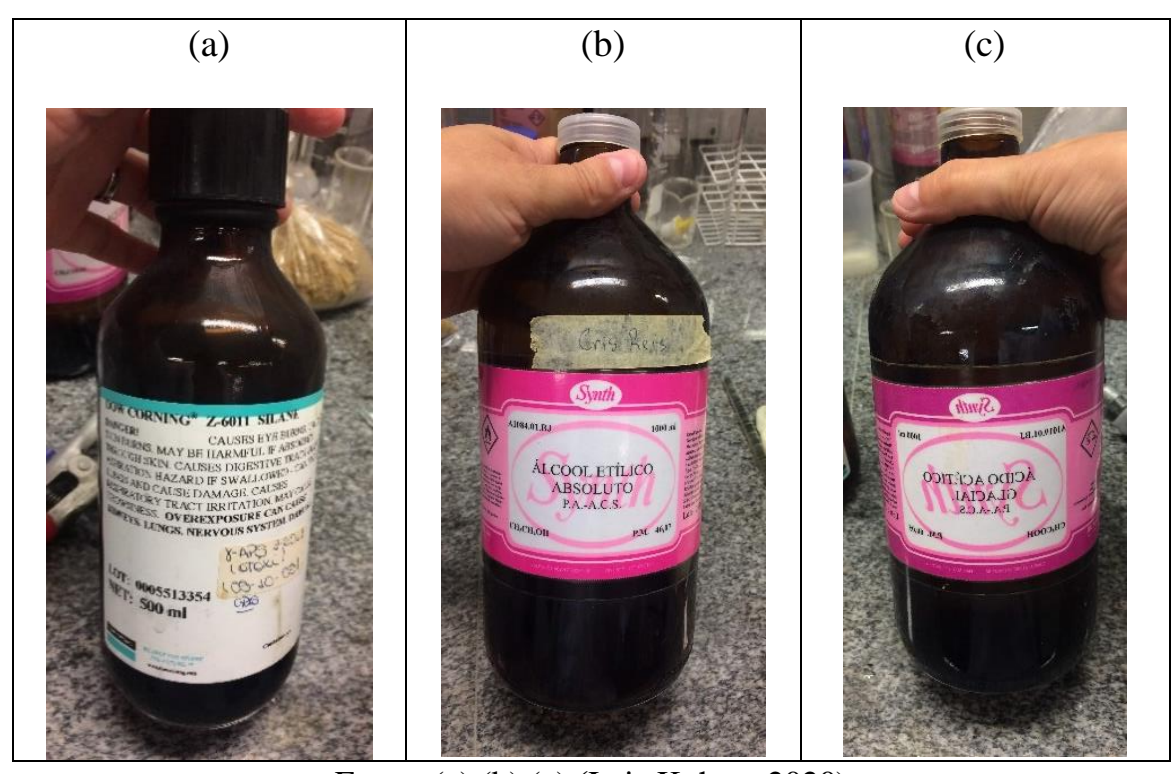

Fonte: (a) (b) (c) (Lais Kohan, 2020) 


\subsubsection{Tratamento das fibras}

A preparação das fibras seguiu etapas de: peneiração, secagem, tratamento em mercerização e tratamento com silano. Todas essas etapas foram feitas no Laboratório de Engenharia e Controle Ambiental (LENCA) da Unifesp (Campus Diadema).

\subsubsection{Preparação das fibras}

A fibra de serragem de bambu recebida continha algumas impurezas, como folhas e resíduos da mucilagem, devido à origem do material, um resíduo do processo de produção de ripas. Para a retirada das impurezas maiores, optou-se por fazer a separação com a peneira granulométrica de 20 mesh $-850 \mu \mathrm{m}$.

Depois, a partir da literatura, identificou-se que eliminar as menores partículas influenciava no resultado do material, o que poderia auxiliar na melhora significativa de propriedades do compósito. Seguindo esse princípio, uma pesquisa avaliou a influência do tamanho da partícula, feita com serragem de madeira em matriz de poliéster, e identificou que partículas de 0,4 $\mathrm{mm}$ a $1 \mathrm{~mm}$ influenciam na melhoria da energia absorvida (TERCIU; CURTU; TEODORESCU-DRAGHICESCU, 2012). Enquanto outras pesquisas em serragem e na matriz igual a esta pesquisa, em PVC, foram processadas em tamanho de $630 \mu \mathrm{m}$ (BODĬRLǍU; TEACĂ; SPIRIDON, 2009) e outra pesquisa comparou alguns tamanhos da serragem e com $500 \mu \mathrm{m}$ obteve melhor resultado (TORRES-GINER et al., 2016). Seguindo esses exemplos, optou-se por utilizar outra peneira menor, a de 35 mesh - $500 \mu \mathrm{m}$ (Figura 49), deixando o tamanho de partícula entre 500-850 $\mu \mathrm{m}$ (ou 0,5-0,85mm).

Figura 49 -Peneira tamanho 35 mesh

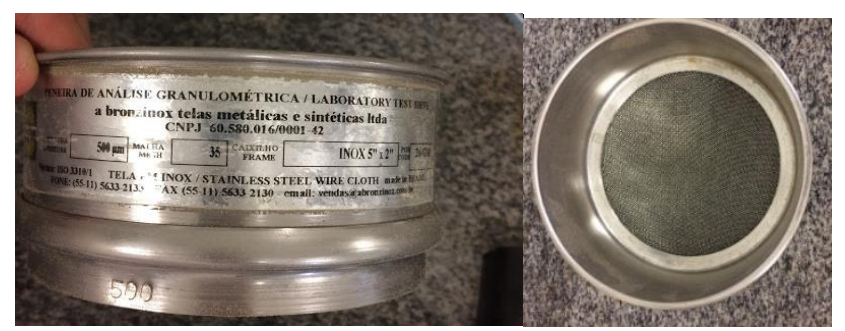

Fonte: (Lais Kohan, 2020)

Após ser peneirada, a serragem passou pela secagem, em estufa termo circuladora Marconi (MA033, Brasil) (Figura 50), a $60^{\circ} \mathrm{C}$, por 12h, para eliminação da umidade da amostra. Esse processo, apesar de simples, tem consequências ao andamento do experimento, 
em que, caso não seja eliminada, pode influenciar na adesão fibra-matriz e degradação (PICKERING; EFENDY; LE, 2016).

Figura 50 - Estufa termo circuladora Marconi (MA033, Brasil)

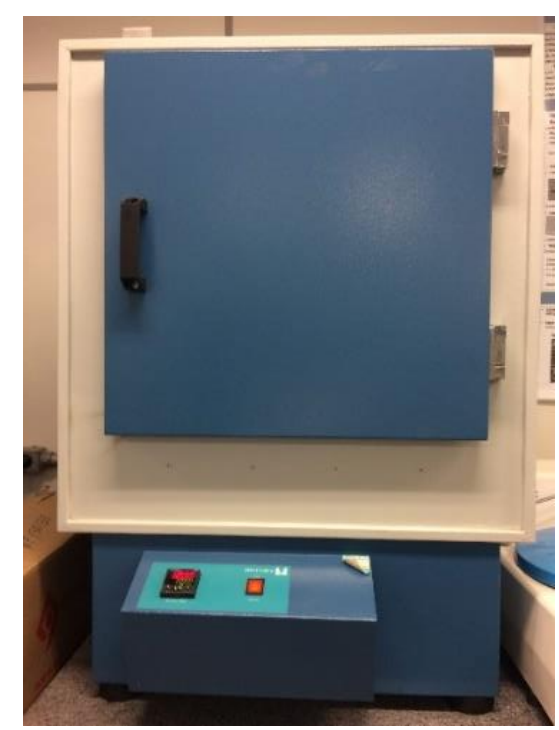

Fonte: (Lais Kohan, 2020)

\subsubsection{Mercerização}

Mercerização é o tratamento das fibras em $\mathrm{NaOH}$ (hidróxido de sódio), ele modifica superficialmente as fibras, removendo parcialmente a hemicelulose, lignina, diminui a agregação das microfibrilas e deixa as fibras mais resistentes (ALBINANTE; PACHECO; VISCONTE, 2013).

No experimento, utilizou-se uma solução alcalina composta por água e concentração de $5 \%$ de $\mathrm{NaOH}$. No banho, as fibras foram imersas na solução, em temperatura de $100^{\circ} \mathrm{C}$, durante 1h, em relação de banho de 1:9 (sólido/líquido) (Figura 51a), seguindo uma referência de pesquisa (ZHANG; CUI; YAN, 2019). Depois de tratadas, separou-se o líquido das fibras, por filtragem e foi feito a lavagem com água por 2h, até a solução tornar-se neutra (Figura 51b). Depois, fibras foram secas em $90^{\circ} \mathrm{C}$ por $16 \mathrm{~h}$. Por fim, constatou-se que as fibras continham umidade em valor menor de $3 \%$. 
Figura 51 - Tratamento da serragem com $\mathrm{NaOH}$ (a) aquecimento: utilizando agitador magnético, misturador e termômetro, (b) lavagem com água para neutralização das fibras

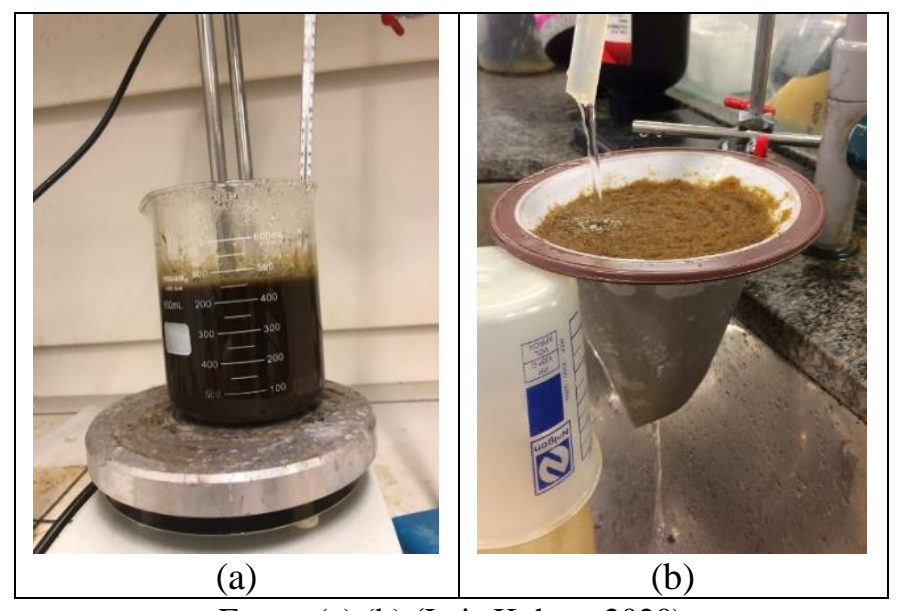

Fonte: (a) (b) (Lais Kohan, 2020)

\subsubsection{Tratamento com silano}

Além da merceirização, foi feita outra opção de tratamento das fibras - a silanização. O agente acoplante, o silano tem uma estrutura genérica: $\mathrm{R}_{(4-\mathrm{n})}-\mathrm{Si}$ - $\left(\mathrm{R}^{\prime} \mathrm{X}\right)_{\mathrm{n}}(\mathrm{n}=1,2)$, onde $\mathrm{R}$ é um grupo alcóxi (alquil ligado a um oxigênio), X uma organofuncionalidade e R', uma ponte alquil. A organofuncionalidade do silano interage com o polímero, por uma ligação covalente e o grupo alquil ajuda a aumentar a compatibilidade com a matriz apolar, devido às polaridades semelhantes. $\mathrm{O}$ aminopropiltrietoxisilano é o agente acoplante mais reportado na literatura, em aplicações de compósitos, em fibras naturais e termoplasticos, inclusive no PVC, foco deste trabalho (SOMBATSOMPOP; CHAOCHANCHAIKUL., 2005; XIE et al., 2010).

O composto da marca Dow-Corning® Z-6011, um aminopropiltrietoxisilano, foi preparado, a partir da mistura de água destilada, etanol da marca Synth, descrito pelo fabricante como Álcool Etílico Absoluto 99,5\%. A quantidade da solução foi preparada em relação de 1:3 (m/m) silano/fibra, na proporção de mistura de $60 \%$ álcool e $40 \%$ água. A adição de $1 \%$ de ácido acético foi feita para correção de $\mathrm{pH}$ com o valor ideal, sendo entre 3,5-4,0, conforme recomendação do fabricante. O agente acoplante silano (1\%) foi misturado lentamente à mistura, concentração definida de acordo com pesquisa que comparou as concentrações e desenvolveu esta metodologia (SOMBATSOMPOP; CHAOCHANCHAIKUL., 2005).

A solução de silano foi gotejada na serragem, através de um funil de adição (piriforme funil com ponta para gotejamento) e, simultaneamente, foi utilizado um misturador de alta velocidade (5 rpm) (Figura 52). Após finalização do gotejamento, permaneceu no misturador 
por 90 min e depois, a mistura foi filtrada em água destilada para a remoção do solvente e neutralização da mistura.

Figura 52 - Ilustra a etapa de gotejamento do silano, através do uso de um funil de adição e um misturador (5rpm)

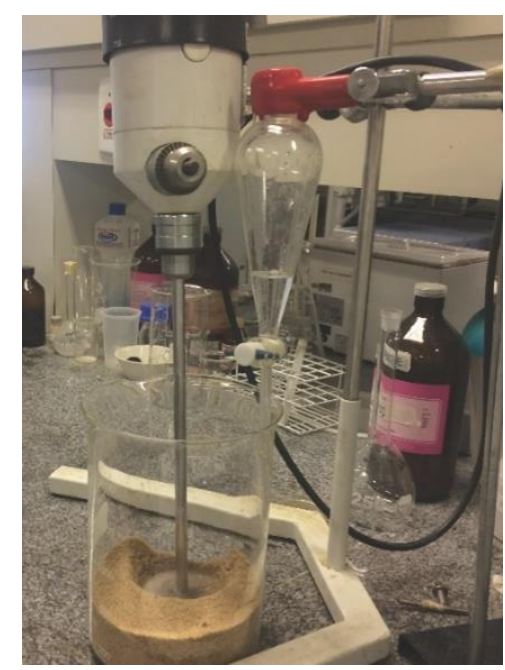

Fonte: (Lais Kohan, 2020)

5.2.5. Maquinário utilizado para a conformação do compósito

Os maquinários utilizados na fase de conformação do compósito pertencem ao laboratório, chamado "Plataforma Multiusuária de Processamento de Materiais Poliméricos da Unifesp", coordenado pela prof. Dra. Cristiane Reis, pertencente ao Departamento de Engenharia Química, localizado no município de Diadema-SP.

Para esta pesquisa, foram utilizados os seguintes maquinários: 
Figura 53 - Equipamentos utilizados no processamento da mistura das fibras e o composto de PVC - (a) calandra MH-150-C-D, (b) prensa automática MH-P-8 MT-PR e (c) prensa hidráulica Tecnalise

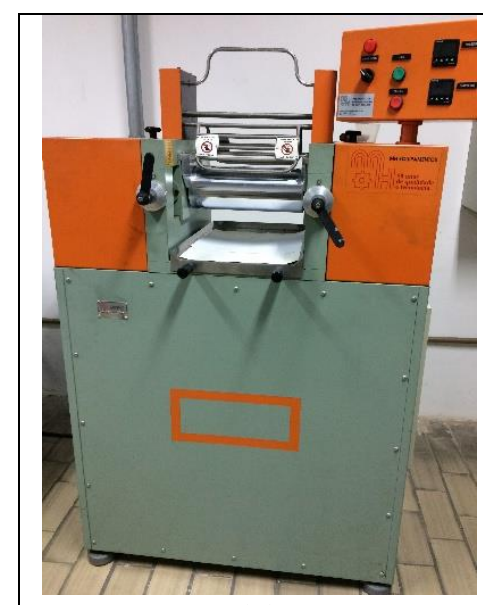

(a)

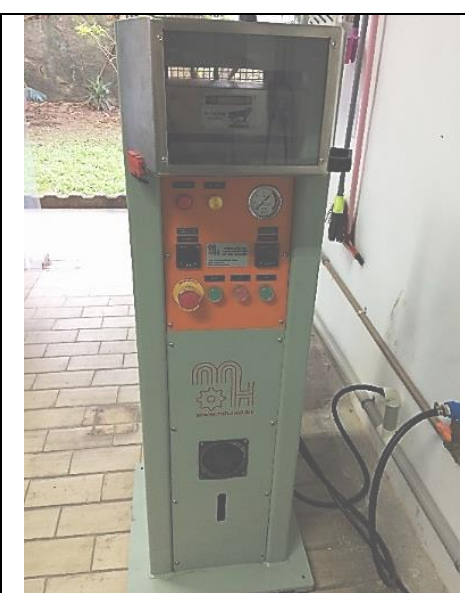

(b)

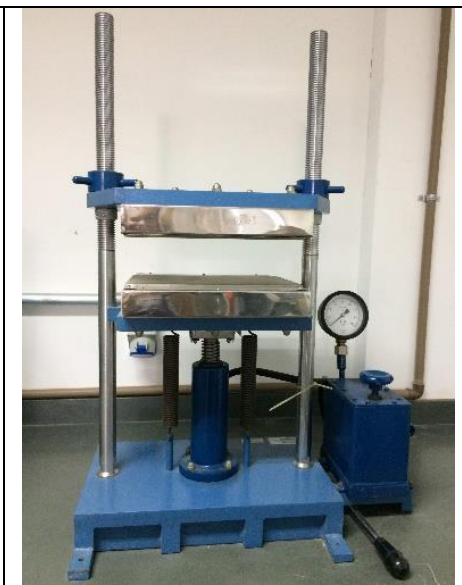

(c)

Fonte: (a) (b) (c) (Lais Kohan, 2020)

\section{- $\quad$ Misturador Calandra MH-150-C-D (Figura 53a)}

Equipamento de dois rolos aquecidos por resistência para desenvolvimento, controle de qualidade e mistura das resinas termoplásticas e elastoméricas. Por meio da rotação de dois rolos de superfície polida e cromada e com temperatura controlada digitalmente, comprime e cisalha o material, gerando assim a forma necessária para incorporar cargas sólidas ou líquidas à massa, transformando rapidamente no produto desejado (MH EQUIPAMENTOS, [s.d.])

- $\quad$ Prensa 1: PRENSA COMP. QUENTE MOT. MH-P-8 MT-PR - 220 V - NR12 (Figura 53b)

Equipamento de prensagem para desenvolvimento dos corpos de prova para análises e controle de qualidade. Há duas etapas: a primeira, aquecida com temperatura controlada para moldar a amostra desejada (grão, pó, flake ou massa fundida); a segunda, o resfriamento das amostras, através circulação interna de água, que não altera as dimensões obtidas na moldagem a quente (MH EQUIPAMENTOS, [s.d.]).

- $\quad$ Prensa 2: PRENSA HIDRÁULICA TECNALISE (Figura 53c).

Prensa hidráulica para corte dos corpos de prova para testes mecânicos no dinamômetro, de acordo com ASTM D412 Standard Test Methods for Vulcanized Rubber and Thermoplastic Elastomers Tension. 


\subsubsection{Processamento do Compósito}

Inicialmente, foram pesadas e separadas as fibras tratadas e não tratadas em porções individuais (Figura 54a e 54b). O mesmo procedimento foi feito com o composto de PVC (Figura 54c). A quantidade de amostras e proporção, em relação a matriz em PVC fibras é apresentada na Tabela 14.

Figura 54 - Pesagem e separação dos insumos do compósito (fibras e composto de PVC) (a) pesagem serragem, (b) separação da serragem (c) separação composto de PVC

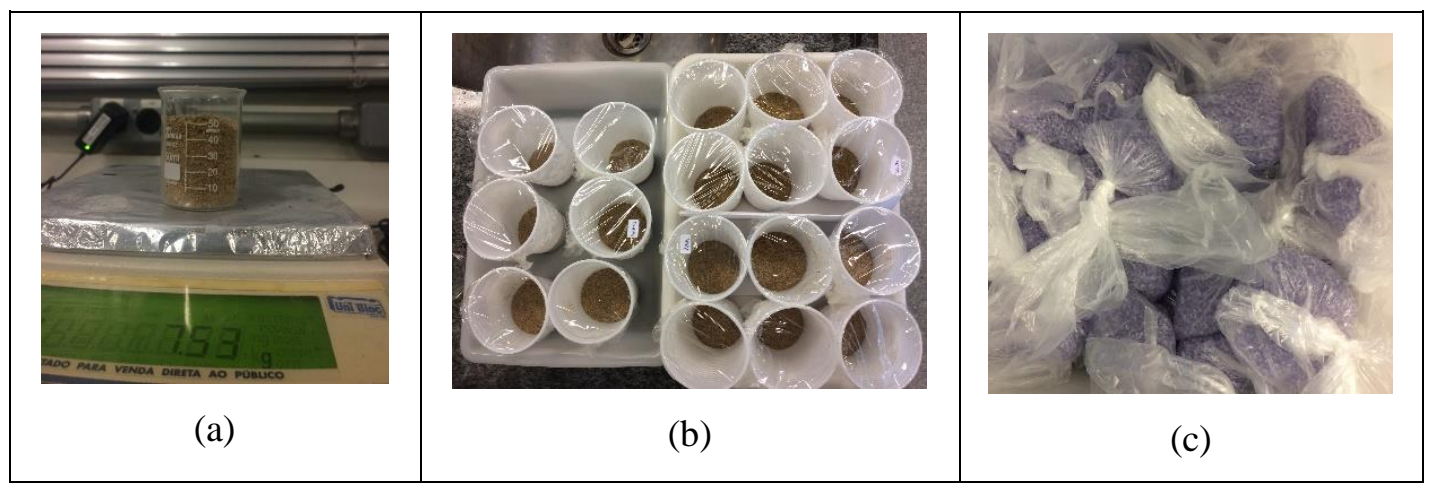

Fonte: (a) (b) (c) (Lais Kohan, 2020)

Tabela 14 - Peso (g) das fibras utilizadas na formulação de PVC, em placa de $150 \mathrm{~g}$

\begin{tabular}{cclcc}
\hline Amostras & \% & Puro & NaOH & Silano \\
\hline p1 & 1,5 & 2,25 & & \\
p2 & 3,0 & 4,50 & & \\
p3 & 6,0 & 9,00 & & \\
\hline m1 & 1,5 & & 2,25 & \\
m2 & 3,0 & 4,50 & \\
m3 & 6,0 & 9,00 & 2,25 \\
s1 & 1,5 & & 4,50 \\
s2 & 3,0 & 9,00 \\
s3 & 6,0 & \\
p: fibra pura - m: fibra mercerizada - s: fibra tratada com silano
\end{tabular}

O processamento do compósito é iniciado na calandra (Figura 53a), ela contém dois cilindros paralelos que giram para dentro, o cilindro da frente é regulado em $160^{\circ} \mathrm{C}$ e o de trás em $150^{\circ} \mathrm{C}$. Coloca-se primeiro o composto de PVC granulado, que é amolecido por temperatura; quando estiver homogeneizado e plastificado (cerca de dois minutos), as fibras são adicionadas para mistura. As fases de plastificação e homogeneização podem ser vistas à olho nu, na qual 
ocorrem o aumento do brilho PVC e as fibras (amareladas) ficam dispersas uniformemente no polímero (transparente). Para ficarem misturadas, utiliza-se uma espátula para retirar o PVC com a fibra do cilindro e reinserir na mistura, até ficarem uniformes (cerca de mais 2 minutos e meio). Durante o processamento, parte dos insumos caem nas bandejas abaixo e, também, são reinseridas na mistura.

A próxima etapa é a prensa automática (Figura 53b) para dimensionar o compósito em uma placa uniforme, ela é conformada por aquecimento a $150^{\circ} \mathrm{C}$ (durante três minutos) em pressão de 150 bar e, depois, resfriada durante o mesmo tempo. Sobre uma forma de ferro quadrada, de lado em $17 \mathrm{~cm}$ e $4 \mathrm{~mm}$ de espessura, o compósito é moldado, conforme ilustrado nas diversas placas apresentadas na Figura 55.

Figura 55 - Placas de compósitos de PVC com serragem de bambu: (a) todas as amostras de compósitos desenvolvidos com serragem pura, tratada com silano e mercerizada, em quantidades em 1,5\%,3,0\% e 6,0\%; (b) comparação visual entre a matriz pura (sem serragem, amostra mais à esquerda) e os compósitos desenvolvidos com serragem pura (sem tratamento), apresentados nas a quantidades de $1,5 \%, 3,0 \%$ e $6,0 \%$, respectivamente.

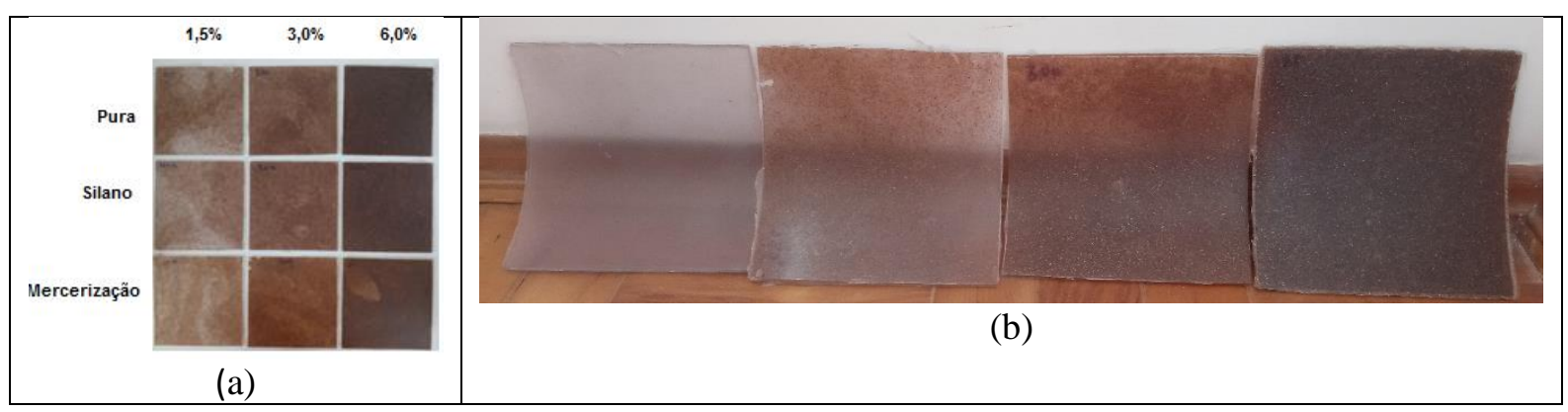

Fonte: (Lais Kohan, 2020)

Com as placas prontas, é possível observar que os tratamentos e as quantidades de serragem de bambu influenciam nas cores dos compósitos desenvolvidos (Figura 55a), nas amostras com serragem tratada por mercerização, o padrão de cor de todas as amostras é mais amarelado, em comparação com as demais. Além disso, a transparência dos materiais também varia de acordo com a quantidade de serragem (\%) utilizada (Figura 55b) e, ainda mais se destaca, quando se confere com a placa do composto de PVC puro.

A última etapa neste laboratório é o corte dos corpos de prova, na prensa hidráulica, para realizar os testes em dinamômetro e morfologia, na fase de caracterização. O molde de ferro e a placa do compósito são inseridos entre as chapas de metal, com suporte de uma base de madeira, para o corte (Figura 56a). As chapas de metal são acionadas por alavanca manual para o corte e as peças são retiradas em formato das "gravatas" (Figura 56b). 
Figura 56 - Prensa hidráulica para corte de corpos de prova (a) prensa, amostra e faca de corte, (b) corpos de provas em formato de "gravatas" (22 mm de corpo, $6 \mathrm{~mm}$ de largura e 3,5 mm de espessura)

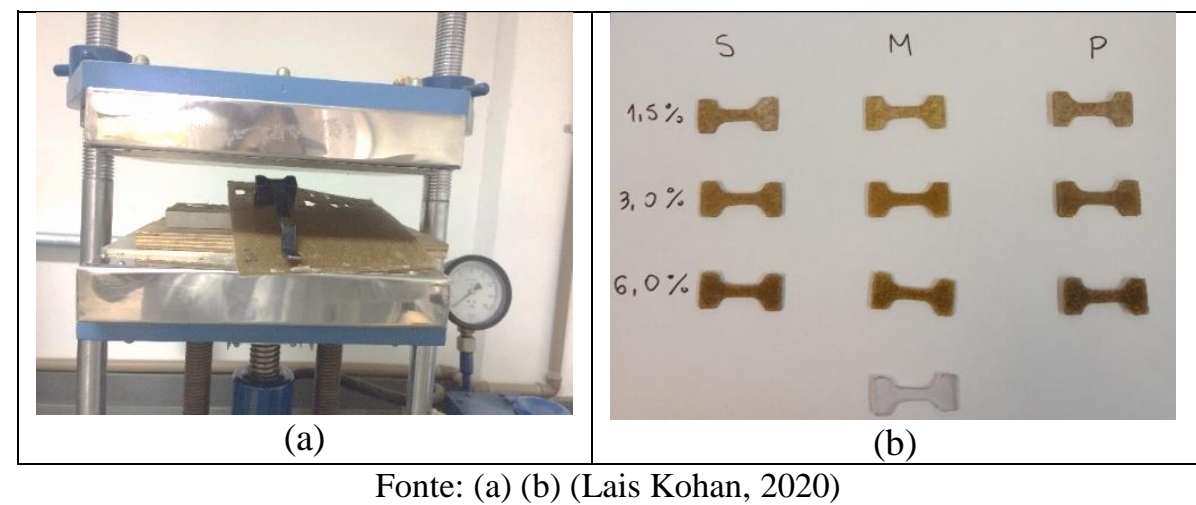

5.2.7. Caracterização da serragem de bambu

\subsubsection{Espectroscopia no infravermelho por transformada de Fourier (FTIR)}

O teste de FTIR foi realizado na empresa Golden Tecnologia (São José dos CamposSP). O equipamento utilizado é da marca Thermo, modelo Avatar 370 FTIR, utilizando célula de ATR Germânio (Ge) (Nicolet, EUA). Utilizou-se o intervalo de 4000 a $700 \mathrm{~cm}^{-1}$, com 32 varreduras e resolução $2 \mathrm{~cm}^{-1}$, dados foram obtidos através do software Omnic, versão 4.1, disponibilizado em 2011 (CALTECH, [s.d.]).

Essa técnica é considerada como uma das mais importantes atualmente para caracterização de fibras, pois mesmo que apresentem diferenças em composições químicas podem ser facilmente identificadas (HOUCK, 2009). Isso acontece porque a espectroscopia de infravermelho possibilita estudos de materiais em diversos estados, através da luz incidente de ondas sobre a matéria (transmitância). O espectro de infravermelho médio (4000-400 cm-1) pode ser dividido em quatro regiões e cada uma tem uma natureza de frequência (Figura 57), seguem elas: ligação X-H (4000-2500 cm $\mathrm{C}=\mathrm{O}$ e $\mathrm{C}=\mathrm{C}\left(2000-1500 \mathrm{~cm}^{-1}\right)$ e impressão digital (1500-400 $\left.\mathrm{cm}^{-1}\right)($ MONTEIRO, 2016; STUART, 2004). 
Figura 57 - Desenho esquemático do FTIR, de acordo com a frequência de cada grupo funcional

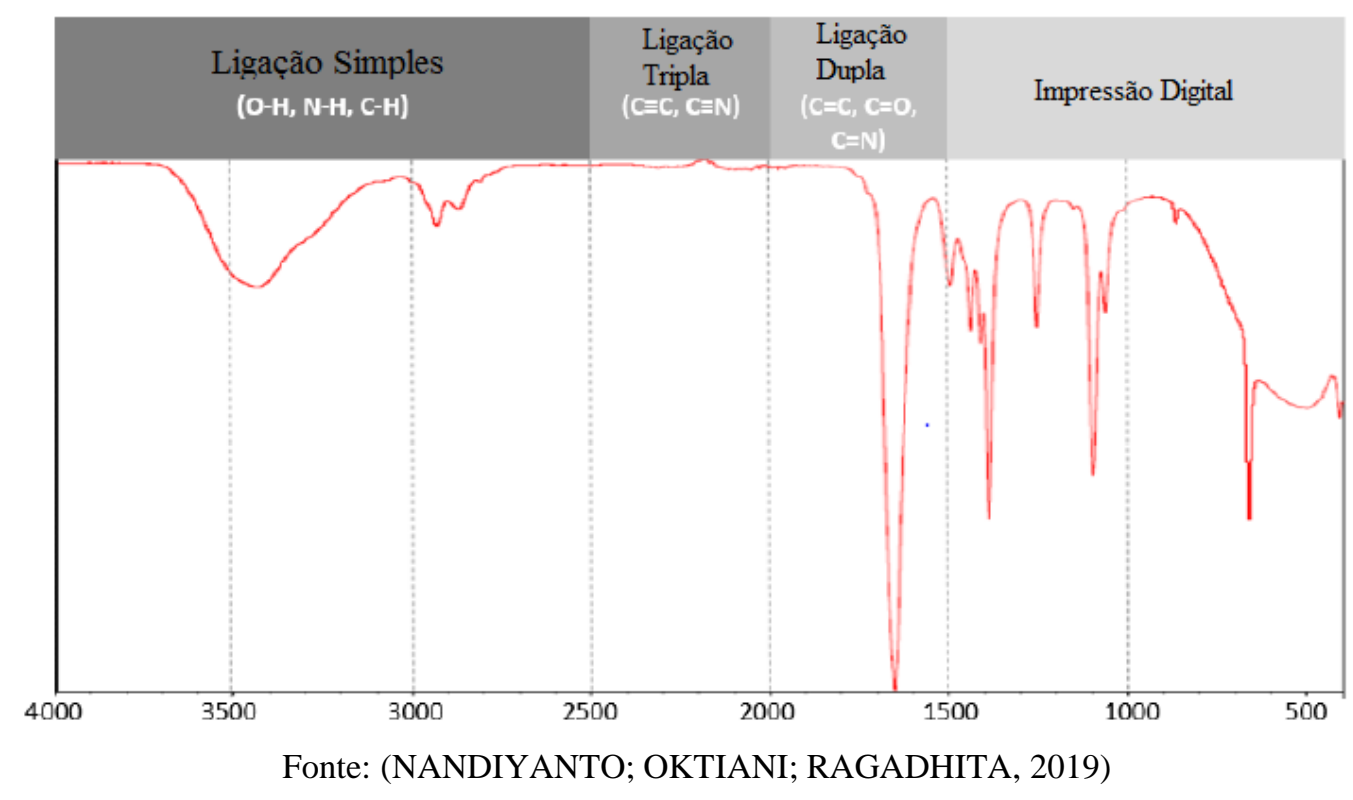

Esta curva pode ser calculada as entalpias de transição, que é feita através dos dados de cada pico correspondente. A entalpia de transição pode ser expressada através da Eq. 1.

$$
\Delta \mathrm{H}=\mathrm{K} \cdot \mathrm{A}
$$

Onde: $\Delta \mathrm{H}$ : Entalpia de transição; K: Constante de calorimetria; A: Área sob a curva.

\subsubsection{DSC (Differential Scanning Calorimetry) - Análise Térmica Diferencial}

A análise térmica diferencial foi realizada Centro de Ciência e Tecnologia Têxtil, no departamento de Engenharia Têxtil, Universidade do Minho, Portugal. O modelo do aparelho é Hitachi STA7200 (Tóquio, Japão) (Figura 58). Utilizou-se amostras pesando entre 5-7 mg colocadas em panelas de platina e testadas em temperatura entre $0-600^{\circ} \mathrm{C}$, a uma taxa de aquecimento de $10^{\circ} \mathrm{C} / \mathrm{min}$, sob vazão de nitrogênio de $200 \mathrm{~mL} / \mathrm{min}$. 
Figura 58 - Equipamento para análises térmicas (Hitachi STA7200)

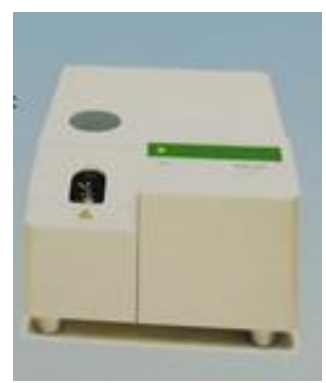

Fonte: (Lais Kohan, laboratório 2C2T-UMinho, 2019)

A análise térmica diferencial é uma técnica que mede o fluxo de energia calorífica em função das transições dos materiais expostos em temperatura. Tais transições são expressas no gráfico gerado e correspondem a eventos térmicos, endotérmicos (absorção de calor) e exotérmicos (perda de calor) (IPT, [s.d.]). Uma fase de transição de grande importância ocorre durante a absorção de calor e é vista como um pico endotérmico, denominado pico de fusão e o resultado é dado pelo software, em temperaturas iniciais e finais do pico de fusão. Ainda é calculado o calor (J/g), necessário para derreter a amostra (THOMAS; SCHMIDT, 2017).

O processo de medição ocorre, através da comparação de fluxo de calor, entre a amostra e uma referência, que é submetida ao mesmo ambiente térmico, só que está vazia (THOMAS; SCHMIDT, 2017).

As análises térmicas são importantes, pois fornecem dados qualitativos e quantitativos para identificar as alterações de propriedades físicas e químicas de produtos, como: temperaturas características, grau de cristalinidade de um polímero, diagrama de fases, entalpias de transição, estabilidade térmica, grau de pureza e cinética das reações (IPT, [s.d.]).

\subsubsection{TGA (Thermo Gravimetric Analysis) - Análise Termogavimétrica}

A análise termogravimétrica foi realizada no Centro de Ciência e Tecnologia Têxtil, no departamento de Engenharia Têxtil, Universidade do Minho, Portugal. O modelo do aparelho é o mesmo utilizado no DSC, em que o aparelho faz a medição concomitantemente. Modelo do aparelho: Hitachi STA7200 (Tóquio, Japão). Utilizou-se amostras pesando entre 5-7 mg, colocadas em panelas de platina, e testadas em temperatura entre $0-600^{\circ} \mathrm{C}$, a uma taxa de aquecimento de $10^{\circ} \mathrm{C} / \mathrm{min}$, sob vazão de nitrogênio de $200 \mathrm{~mL} / \mathrm{min}$. 
A análise termogravimétrica é, normalmente, o primeiro teste realizado para caracterizar um novo material, pois dados obtidos podem detectar e quantificar a presença de água e identificar a temperatura na qual ocorre a decomposição molecular (alteração química). A mudança da massa, ao sofrer degradação, é medida pelo TGA, em função do tempo ou temperatura (THOMAS; SCHMIDT, 2017).

O teste de TGA, normalmente, é feito juntamente com o DSC, no mesmo equipamento, e os dados resultantes são apresentados em gráficos. É apresentado no gráfico, mais uma curva, a DTG (Derivative Thermogravimetry), que é a derivada da TGA. Importante destacar que os dados obtidos na TGA, podem ser associados à composição do material, porém a estrutura física ou a forma do material é determinada pela DSC, como visto anteriormente (THOMAS; SCHMIDT, 2017). No caso específico das fibras de fonte celulósica, associa-se a composição, através da degradação do material, em cada faixa de temperatura que a fibra é exposta, assim, a degradação dos componentes da celulose ocorre nas seguintes temperaturas: hemicelulose entre $250-300{ }^{\circ} \mathrm{C}$, celulose entre $300-350{ }^{\circ} \mathrm{C}$ e lignina entre $300-500{ }^{\circ} \mathrm{C}$ (SONG et al., 2004).

\subsubsection{Caracterização mecânica e morfológica dos compósitos}

Os testes listados abaixo são designados para borracha vulcanizada ou termoplásticos elastômero, como é o caso do PVC flexível. As normas ASTM - American Society for Testing and Materials foram usadas como método, a fim de analisar a qualidade do compósito. As propriedades mecânicas analisadas neste trabalho tiveram o intuito de comparar as novas amostras com fibras de bambu e PVC, em relação ao PVC puro, uma formulação para solados.

Além do resultado encontrado, a partir da comparação de materiais, utilizou-se estudos anteriores recentes, correlatos à solados e compósitos, para complementar a análise (DREGER et al., 2018; PAIVA et al., 2018).

\subsubsection{Tensão, alongamento e módulo de elasticidade}

Para esses testes, foi usado o dinamômetro (Figura 59) da marca Instron - modelo 5569 (Norwood, Estados Unidos). Os ensaios foram realizados no laboratório de Física Têxtil, na Escola de Artes, Ciências e Humanidades da Universidade de São Paulo - EACH-USP. 
Figura 59 - Dinamômetro Instron - modelo 5569

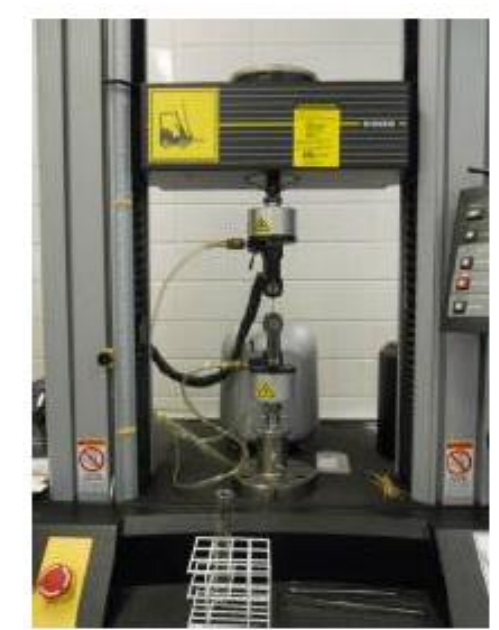

Fonte: (Lais Kohan, 2020)

ASTM D412 - 16 - Standard Test Methods for Vulcanized Rubber and Thermoplastic Elastomers Tension. Escopo: o procedimento é usado para avaliação de tensão em borracha vulcanizada termofixa e termoplásticos elastômeros, mas não é aplicado para materiais com baixo alongamento (ASTM INTERNATIONAL, 2016).

Preparação: foram utilizados seis corpos de prova, por tipo compósito. Há recomendações sobre o estado das amostras, assim, se obtida de um artigo fabricado, a amostra deve estar livre de rugosidade da superfície. A temperatura padrão para o teste deve ser $23 \pm 2{ }^{\circ}$ e devem ser condicionadas por pelo menos $3 \mathrm{~h}$ a $23^{\circ} \mathrm{C}$.

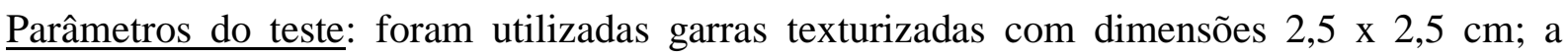
distância entre as garras foi de $20 \mathrm{~mm}$; célula de carga de $1 \mathrm{kN}$ e velocidade $20 \mathrm{~mm} / \mathrm{min}$.

No dinamômetro, em todas as amostras foram medidas a espessura e o tamanho da parte útil (comprimento e largura), em que eram alimentados no software, antes de realizar o teste. $\mathrm{O}$ comprimento da parte útil era medido e ajustado, no equipamento, para garantir que a amostra não ficasse dobrada, uma vez que o polímero utilizado era flexível.

Realizaram-se os seguintes testes: valor de carga máxima $(\mathrm{N})$, valor da carga na quebra $(\mathrm{N})$, resistência à tração na carga máxima $(\mathrm{MPa})$, alongamento $(\%)$, deformação $(\mathrm{mm})$ e módulo de Young (MPa). Todos esses valores foram fornecidos pelo Bluehill ${ }^{\circledast}$ Software do dinamômetro. Fórmulas da bases de cálculo são mostradas a seguir nas equações de resistência à tração (Eq.2) e alongamento (Eq.3) (ASTM INTERNATIONAL, 2016): 


$$
T=F / A
$$

Onde: T: resistência à tração $(\mathrm{MPa}) ; \mathrm{F}$ : força $(\mathrm{MN}) ; \mathrm{A}$ : área seccional $\left(\mathrm{m}^{2}\right)$

$$
A=100 \cdot\left(L-L_{0}\right) / L_{0}
$$

Onde: A: alongamento (\%); L: distância entre as marcas de referência na amostra estendida; $\mathrm{L}_{0}$ : distância original entre as marcas de referência

Como resultado, a principal curva a ser analisada é a de tensão-deformação, em que é expressa pela Figura 60. A partir dela que é possível comparar, visualmente, o comportamento tênsil dos compósitos analisados. Outro dado importante extraído é o valor do módulo de Young, o comportamento elástico do material (Eq. 4), referente à reta inicial do gráfico abaixo, do ponto "0" até o ponto "A"(YOUNG; FREEDMAN, 2008).

Figura 60 - Curva esquemática da tensão-deformação de materiais

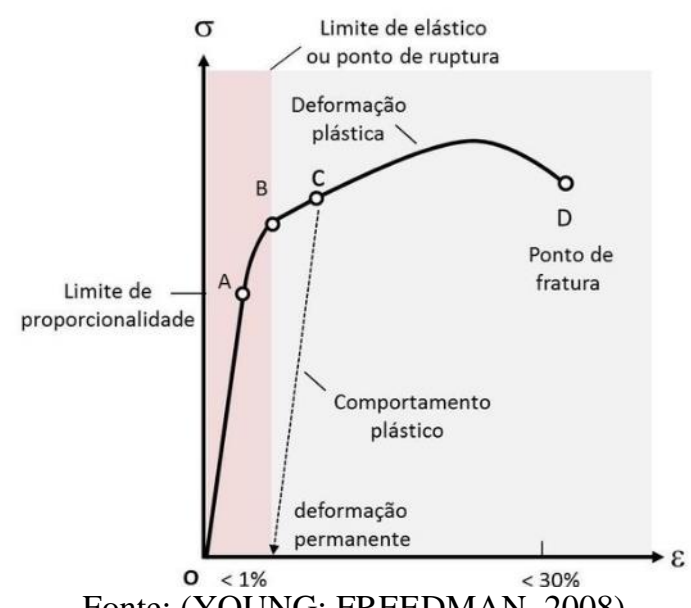

Fonte: (YOUNG; FREEDMAN, 2008) 


$$
E=\frac{\delta}{\varepsilon}
$$

Onde: E: módulo de Young; $\delta=$ tensão aplicada (MPa); $\varepsilon=$ deformação elástica $(\%)$

\subsubsection{Análise Morfológica em Microscópio Eletrônico de Varredura (MEV)}

Teste realizado em Microscópio Eletrônico de Varredura de Alta Resolução Jeol 7100FT, no Centro Brasileiro de Pesquisas Físicas em Biomateriais no Rio de Janeiro - RJ.

As amostras foram fraturadas em nitrogênio líquido e colocadas sobre stub de alumínio, com fita de carbono, e recobertas com ouro. Foi utilizada a aceleração de $15 \mathrm{kV}$ e distância de trabalho (WD) $12-15 \mathrm{~mm}$.

Importante destacar que o uso desse equipamento, especialmente para polímeros, é importante análise para estudar as superfícies fraturadas, tamanho e forma das partículas, orientação da carga e a dispersão delas, nas matrizes poliméricas (GUISE; STROM; PRESCHILLA, 2011).

Na preparação da amostra foi utilizada a fratura criogênica, método específico para polímeros para analisar deformações plásticas, em zonas de cisalhamento para polímeros vítreos ou semicristalinos (DEDAVID; GOMES; MACHADO, 2007). A fratura é feita a partir da inserção da amostra em nitrogênio líquido, que o enrijece e, em seguida, é feita a ruptura do material. Na figura abaixo pode ser visto a diferença visualmente entre um material por fratura normal (Figura 61a) e, outro, por fratura criogênica (Figura 61b).

Figura 61 - Visualização de polímero polipropileno após fratura para realização do teste MEV - (a) fratura normal, (b) fratura criogênica
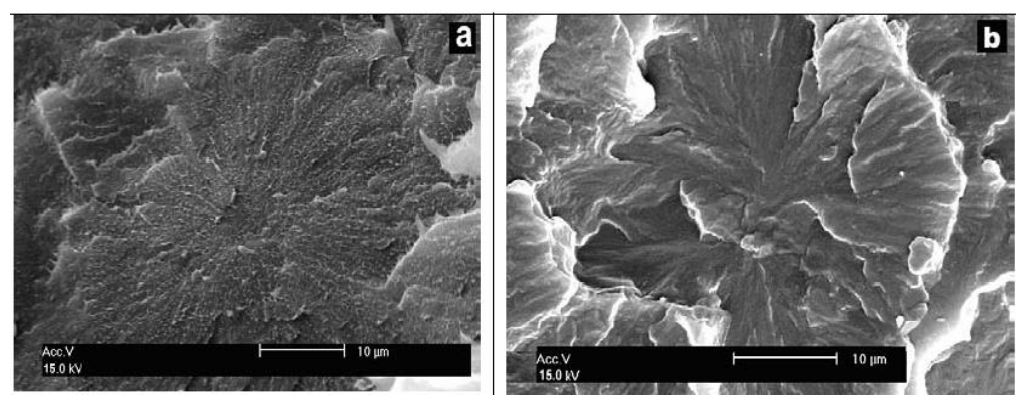

Fonte: (DEDAVID; GOMES; MACHADO, 2007) 
5.2.9. Análise estatística dos resultados

5.2.9.1. Média, desvio padrão e coeficiente de variação

A partir dos resultados dos testes mecânicos, foram calculados os parâmetros estatísticos de média (Eq. 5), desvio-padrão (Eq. 6) e coeficiente de variação (Eq. 7).

$$
\begin{gathered}
\bar{x}=\frac{\left(\sum x\right)}{n} \\
s=\sqrt{\frac{\sum(x-\bar{x})^{2}}{n-1}} \\
C V \%=\frac{s}{x} * 100
\end{gathered}
$$

\subsubsection{Teste de hipótese}

Para verificar se uma hipótese é verdadeira ou falsa no mundo real, o investigador seleciona uma amostra dessa população alvo para testar a hipótese, em que necessita fazer inferências sobre os fenômenos sobre a população. Inicia-se presumindo que a hipótese é nula ou nenhuma associação entre o preditor e as variáveis de resultado na população. Com base nos dados coletados em sua amostra, o investigador usa testes estatísticos para determinar se há evidências suficientes para rejeitar a hipótese nula em favor da hipótese alternativa de que há uma associação na população. O padrão para esses testes é mostrado como o nível de significância estatística (BANERJEE et al., 2009).

Quando uma amostra não é representativa da população, assim, os resultados da amostra não refletem a realidade da população, e o erro aleatório leva a uma inferência errônea. Um erro tipo I (falso-positivo) ocorre se um investigador rejeitar uma hipótese nula que é realmente verdadeira na população; um erro do tipo II (falso-negativo) ocorre se a investigador falha em rejeitar uma hipótese nula que é realmente falsa na população. Embora os erros do tipo I e do 
tipo II nunca possam ser evitados inteiramente, o investigador pode reduzir sua probabilidade (BANERJEE et al., 2009).

Quando os dados são analisados, esses testes determinam o valor $\mathrm{p}$, a probabilidade de se obter os resultados do estudo por acaso se a hipótese nula for verdadeira. A hipótese nula é rejeitada em favor da hipótese alternativa se o valor $\mathrm{p}$ for menor que alfa, o nível prédeterminado de significância estatística (DANIEL W. W., 2002)

No presente estudo, adotou-se para um erro tipo I, com $\alpha=5 \%, \mathrm{p}$ (p-value) menor que 0,05 foram considerados estatisticamente significantes para aceitação da hipótese nula. Foi realizado o teste de normalidade, a partir da distribuição dos dados e da homogeneidade da variância, através dos softwares Minitab e o Action Stat. Na comparação das médias de mais de dois grupos de dados numéricos contínuos, foi utilizado a ANOVA.

\subsubsection{Análise de variância (ANOVA)}

$\mathrm{Na}$ análise de variância pode-se fazer a relação entre diversas variáveis independentes com uma variável dependente métrica e analisar a variância entre os tratamentos. Esse método é obtido pela decomposição da variação total da variável resposta em partes que podem ser atribuídas ao tratamento e ao erro experimental (HOOKER, 2007).

O valor da "variância entre as amostras" será tanto menor quanto mais semelhantes forem as médias amostrais, o inverso ocorrendo, quando as médias diferirem muito entre si. Por outro lado, o valor da "variância dentro das amostras" não é afetado pela variação existente entre as diferentes médias amostrais.

Em consequência disso, a razão entre as variâncias entre e dentro, isto é, o valor de $\mathrm{F}$ calculado por intermédio da Equação 8.

$$
F=\frac{S_{E}^{2}}{S_{D}^{2}}
$$

tanto maior quanto mais diferentes forem as médias das amostras analisadas. 
Onde: F: valor calculado de F de Snedcor; $S^{2}$ E: variância entre as amostras; $S^{2}$ : variância dentro das amostras

\subsubsection{Análise dos resíduos}

Para avaliar os dados encontrados nos experimentos é exigido a análise estatística paramétrica, em que assume uma certa distribuição dos dados, geralmente através da distribuição normal, o que atribui aos dados a validade ou confiabilidade (YAP; SIM, 2011). Para esta pesquisa, para avaliar a normalidades dos resíduos foi utilizado o seguinte método gráfico (MINITAB INC., 2000):

- Anderson-Darling: por este método há a comparação da distribuição cumulativa empírica dos dados de amostra da distribuição esperada se os dados estiverem na normalidade. Se a diferença observada for suficientemente grande, o teste rejeitará a hipótese nula de normalidade da população.

Para verificar a variância de resíduos foi usado o seguinte método:

- Barlett: usada para verificação de teste de hipótese de homogeneidade. 


\section{RESULTADOS E DISCUSSÃO}

\subsection{Entrevistas com empresas participantes da Feira Inspiramais}

6.1.1. Análise dos dados obtidos a partir da busca nos sites das empresas participantes do Inspiramais (calçados)

Os dados para desenvolvimento de gráficos e tabelas abaixo foram coletados do site da feira Inspiramais, do qual foram retiradas informações dos participantes que expuseram no evento, ocorrido em janeiro de 2020, cujas empresas pertenciam ao segmento de calçado. Na página, havia um total de 182 companhias, que foram classificadas de acordo com o ramo produtivo (Figura 62). A maior quantidade de empresas são fornecedoras de componentes, totalizando $116(64 \%)$, ramo principal e foco de busca de informações desta pesquisa; seguido de $12 \%$ de empresas não encontradas, por não terem site ou não existirem mais; $10 \%$, insumos; dentre outras.

Figura 62 - Categoria das empresas participantes do Inspiramais (edição de janeiro, 2020) no segmento de calçados

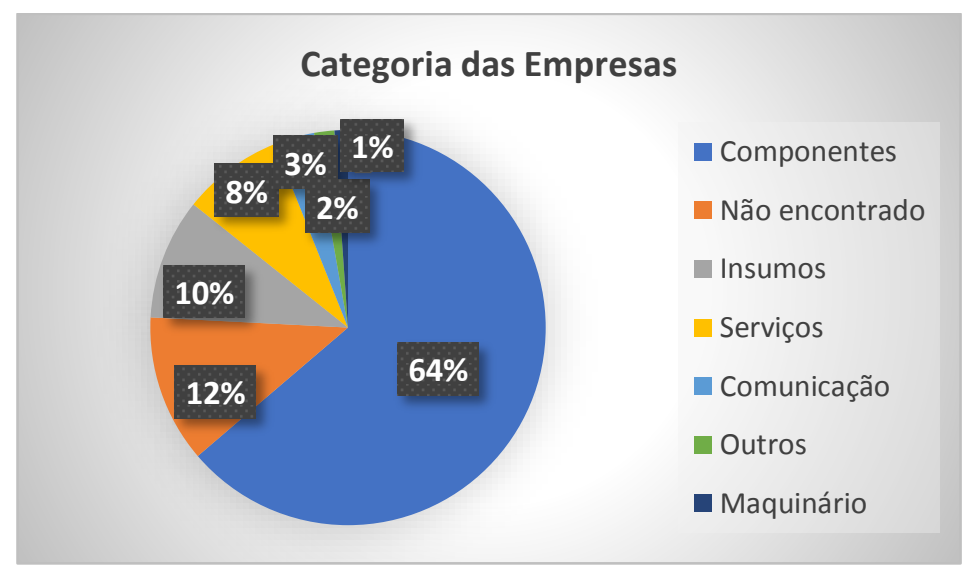

Fonte: (Lais Kohan, 2020)

Para caracterização das empresas, foram consultados os dados cadastrais, no site da Receita Federal (RECEITA FEDERAL, 2018), para definir o porte da empresa e a localização da sede, apresentadas na Figura 63a e b. Sobre a localização, foi indicado o estado em que se localiza a empresa, mas no caso de companhias com mais de uma unidade, assim, foram enquadradas como "VÁRIOS". O estado de São Paulo foi a principal região de origem dos participantes do evento, seguido pelo Rio Grande do Sul. O perfil das empresas, de acordo com 
a classificação do IBGE, aponta a participação decrescente em médio, pequeno e micro porte, respectivamente.

Figura 63 - Caracterização das empresas participantes do Inspiramais (a) Localização por estado brasileiro (b) Porte das empresas

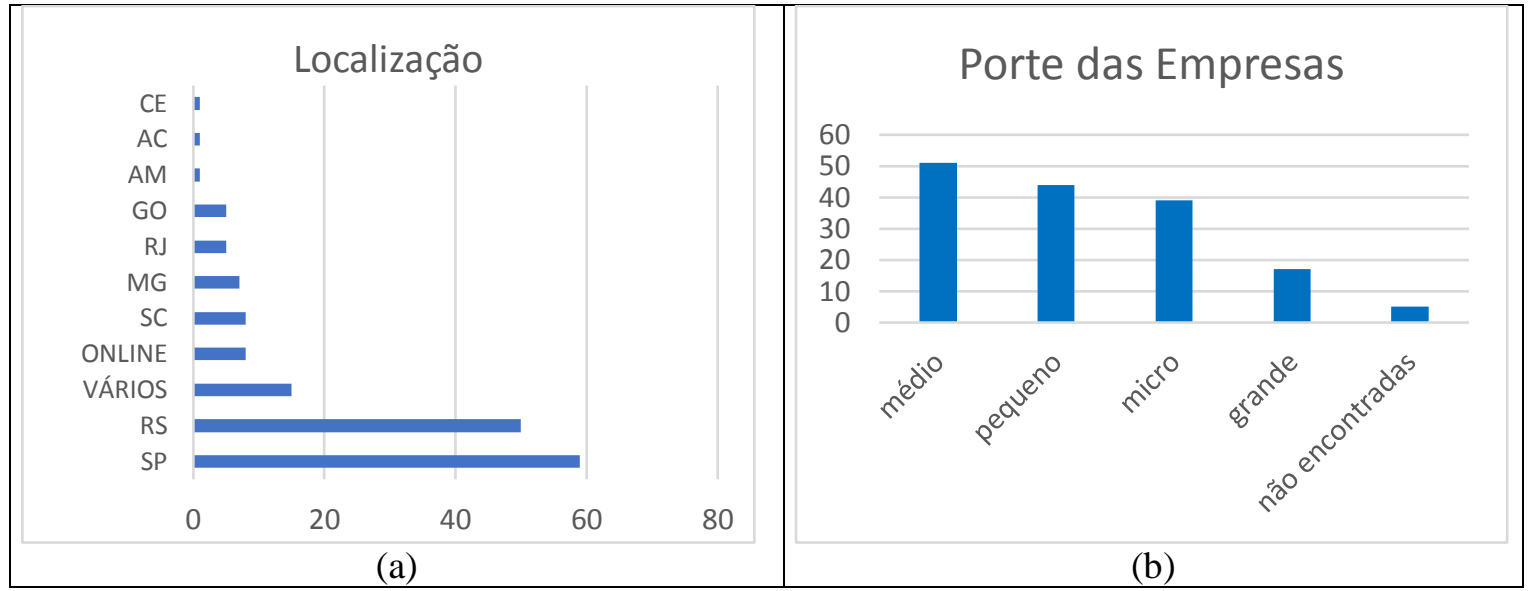

Fonte: (a) (b) (Lais Kohan, 2020)

A variedade de componentes utilizados para desenvolver os modelos de calçados é grande e já foi mostrada nos capítulos anteriores, assim como a importância de cada parte do calçado, em função da estrutura para sua construção, sustentação e conforto. O que também pode ser conferido na diversidade de componentes, no Inspiramais (Figura 64). Os materiais têxteis representam o maior volume de empresas fabricantes, motivo pelo qual ocorreu o agrupamento entre algumas categorias de: tecidos, elásticos, cordoaria, passamanaria, zíper e linhas; em seguida, destacam-se as empresas injetoras de solado, devido à variedade dos diferentes polímeros; curtumes, com predomínio do couro bovino; ferragens, em metais, como fivelas e fechos; laminados; entre outros. 
Figura 64 - Ranking de quantidade de empresas de componentes da Feira Inspiramais (edição janeiro de 2020)

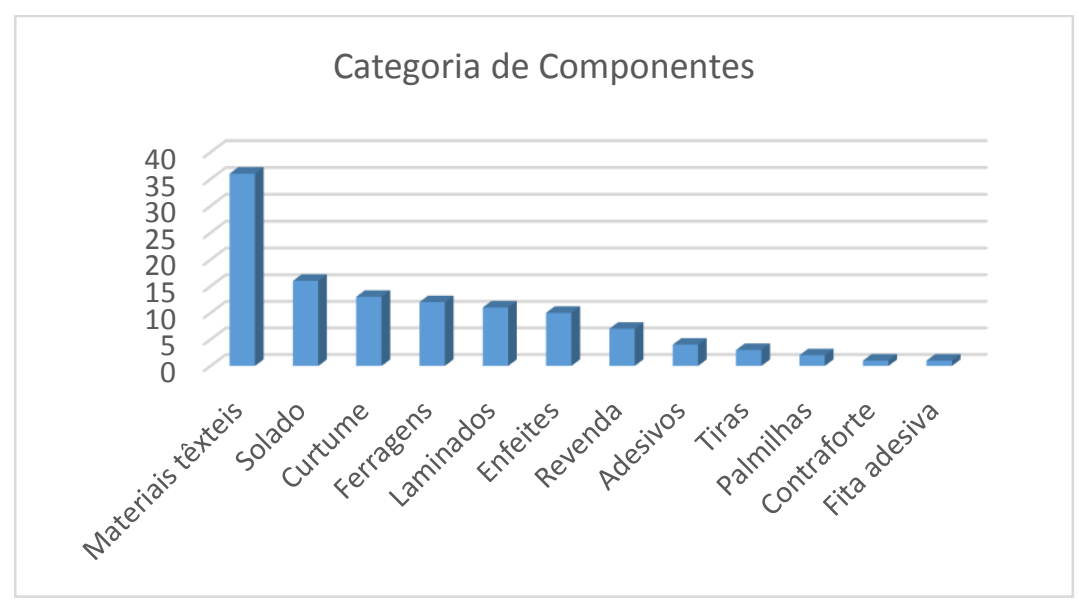

Fonte: (Lais Kohan, 2020)

As informações sobre as iniciativas sustentáveis dos participantes do Inspiramais são apresentadas na Figura 65, a porcentagem fora calculada, com base nas 160 válidas, excluindo as 22 não encontradas. Totalizaram 63 empresas (40\%), que fizeram no mínimo uma, ou até três tipos de ações, dentre seis critérios desenvolvidos. Entretanto, ainda constitui o maior número, 90 empresas (56\%), que ainda não fazem ou não apresentaram em suas páginas tais ações; e, mais sete empresas (4\%), que não se aplicam à classificação da pesquisadora, pois são, principalmente, do ramo de comunicação.

Figura 65 - Empresas do Inspiramais (edição janeiro de 2020) com ações sustentáveis (a) Empresas com ações sustentáveis (\%), dentre o conjunto de participantes (b) Classificação e frequência por tipo de ações sustentáveis feitas nas empresas

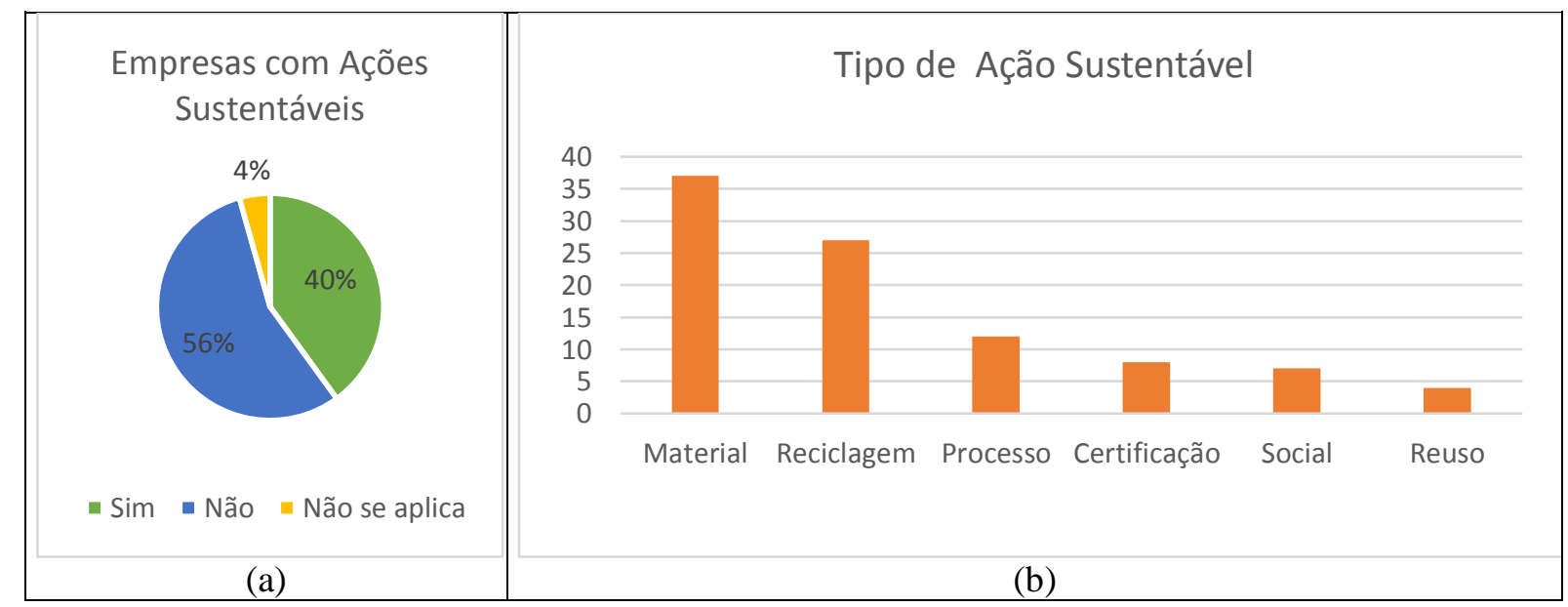

Fonte: (Lais Kohan, 2020) 
A ação sustentável levantada, mais frequente é a de "material”, cuja classificação inclui: uso de polímeros em base vegetal, fio em fibra natural, matérias primas recicladas, isento de solvente aromático e metais pesados, base d'água, entre outros. A segunda ação é a de "reciclagem", que incluem, principalmente, a reciclagem dos materiais e tratamento de água; em terceiro, o de "processo", que se enquadram a redução de emissões, baixo consumo de energia, uso de energia renovável; seguido de certificações (não considerando nesse critério a ISO9001, de qualidade); social, inclui ajuda às comunidades ou programas sociais; e reuso, como reutilização de solventes do processo. No Apêndice $\mathbf{G}$ encontra-se o detalhamento das ações que foram classificadas em cada categoria.

Por fim, com o intuito de ver o grau de importância das ações sustentáveis para essas empresas, foi classificado de acordo com o local onde foram coletadas as informações, dentro dos sites (Figura 66). A maioria das empresas deram bastante destaque e deixaram já na primeira página (34 empresas), enquanto outras deixaram as ações apresentadas junto com a parte institucional (15), e ainda, outras mostraram somente na ficha técnica (12); esta última, é um exemplo de empresas que dão pouco destaque ao assunto, deixando só para o produto, em sua matéria prima natural ou reciclada, por exemplo, não transparecendo que a empresa tem uma preocupação ambiental ou social mais ampla.

Figura 66 - Local de destaque no site, onde é inserida as informações sobre as ações sustentáveis das empresas participantes do Inspiramais (edição janeiro de 2020)

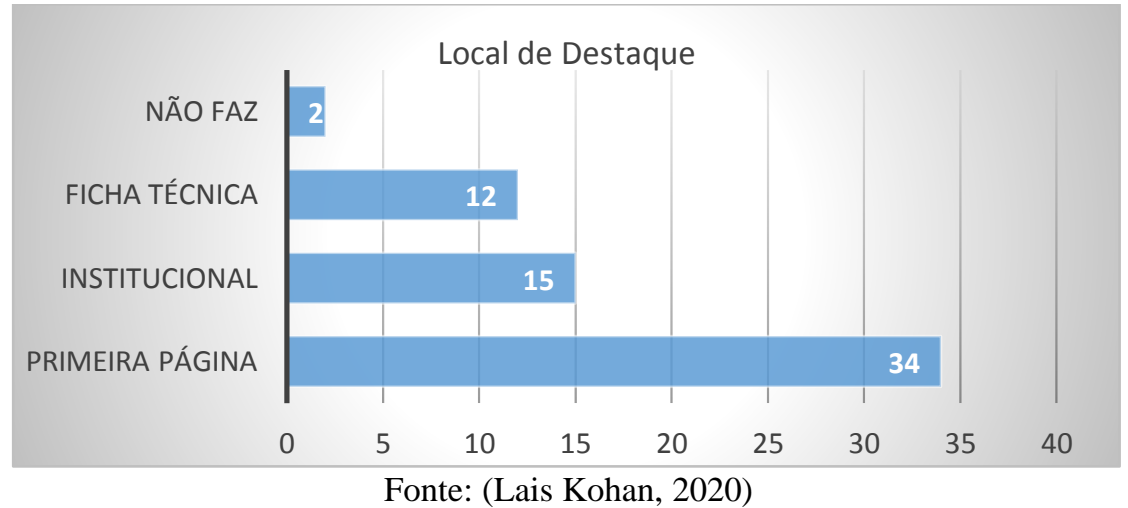


6.1.2. Dados obtidos a partir das três entrevistas realizadas durante a feira Inspiramais (15 e 16 janeiro de 2019)

Empresa A - Fabricante de solados de EVA

Trata-se de empresa de comércio, industrialização de solados de EVA, localizada na cidade de Campo Bom - RS, de médio porte e fundada em 2013. Ela tem o faturamento de 1,3 milhões/mensais em produção de 12.000 pares/dia.

O segmento de atuação principal é o nacional em calçados esportivos e casual atende as maiores marcas presentes no mercado, que são principalmente de produtos licenciados.

O processo de injeção para solado EVA é simples para fazer a alteração das propriedades mecânicas, como a densidade, dureza e abrasão, através da modificação da formulação. Porém, de acordo com a entrevista, o preço varia dependendo da dureza, pois quanto mais macio, mais caro fica.

O processo de produção da empresa é apontado por ser sustentável, no ponto de vista de não haver desperdícios. O produto é feito sob medida para os clientes em moldes injetados e as das sobras, vindas do espaço entre o bico injetor e o molde, são moídos e reabsorvidos no processo.

Empresa B - Fabricante de tecidos

Empresa de comércio de pequeno porte, que terceiriza a facção de tecidos e de tingimentos (acabamentos), e ainda realiza dublagens e aplicação de resinas. Está localizada em Estância Velha - RS. Ela tem 4 anos de funcionamento e vende cerca de 100.000 m/mês (2018).

O produto carro-chefe são tecidos em denim e lonas mistas de algodão, que variam a composição entre: 50\% CO/50\% PES; 60\% CO/40\% PES e 70\% CO/30\% PES, em gramatura que variam entre $220-320 \mathrm{~g} / \mathrm{m}^{2}$. Os tecidos são direcionados a todos os segmentos de calçados (feminino, masculino e infantil) e, também, de bolsas e acessórios.

Ações sustentáveis foram apontadas na utilização de fios reciclados de Poli tereftalato de etileno (PET). 
Empresa C - Fabricantes de palmilha de montagem

A empresa é fabricante de palmilhas de montagem e de outros produtos como embalagens, brinquedos etc. Ela se enquadra no tamanho de empresa de médio porte e está localizada na cidade de Taquara-RS. Atua no mercado nacional e na América Latina, sua produção diária (em placas) é de $12.000 \mathrm{~m}^{2}$.

O principal produto é a palmilha de montagem, que é fabricada com matérias primas recicladas do calçado, sendo que até $50 \%$ é constituída por resíduo. O resíduo provém de uma grande variedade de matérias-primas, usadas por fabricante de sapatos, como: laminado sintético, solados, EVA, tecidos e espuma. Mesmo assim, ainda são usados materiais virgens de polímeros sintéticos, como polipropileno, poliestireno e PET, recobertos com nãotecido de poliéster (Figura 67).

Figura 67 - Palmilha de montagem reciclada (em placa e aplicada) empresa Ambiente Verde
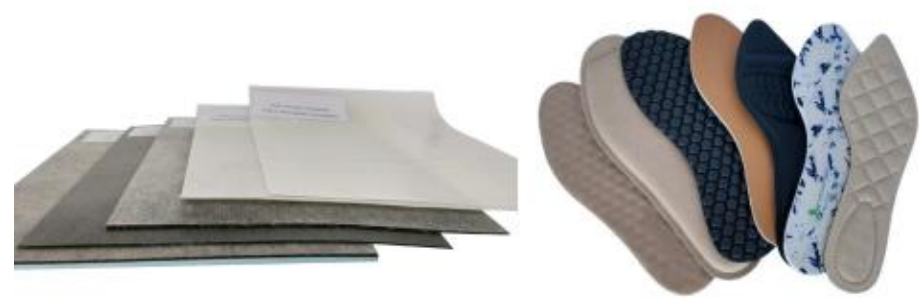

Fonte: (AMBIENTE VERDE, 2019)

De acordo com o fabricante, existe uma vantagem na adoção desse processo de reciclagem que permite um custo final do produto um pouco abaixo do valor do mercado do produto concorrente, feito em papelão, o mais comum no segmento.

A proposta de negócio da empresa permite que o cliente utilize seus resíduos próprios e que parte do custo seja abatido na aquisição do produto. A empresa também compra resíduos de outras indústrias calçadistas para consumo próprio.

Os materiais de contraforte foram testados pelo IBTec (Instituto Brasileiro de Tecnologia do Couro, Calçado e Artefatos), principal laboratório certificado do setor que apresentaram aprovação nos testes de flexibilidade, resistência, de acordo com as normas brasileiras de componentes. Os certificados resultantes dependem das diversas modalidades de produtos, de acordo com a qualidade e com preço compatíveis também. 
As etapas produtivas para produção do produto são: trituração, homogeneização, formulação, blindagem, extrusão e acabamento.

6.1.2. Resultado das duas entrevistas realizadas com visitas técnicas nas empresas

A sumarização das entrevistas realizadas se encontra no Apêndice B e C. A partir dessas informações é feita a análise de dados, como segue.

Empresa D - Fabricante de tecido

A empresa D é uma indústria têxtil brasileira, de médio porte, e está localizada em Franco da Rocha, São Paulo. Este grupo é composto por cinco maiores fornecedoras de tecidos para calçado do Brasil. Ela faz parte de um grupo, composto por cinco indústrias, localizadas em diversos estados (São Paulo, Rio Grande do Sul, Sergipe e Bahia), com atuação focada no segmento calçadista, através de negócios em manufatura de tecidos, dublagem, estampagem e palmilhas.

Os maquinários utilizados pela empresa são teares em malharia de urdume, em máquina Kettenstull (2 a 4 barras) e circular (plana e jacquard). Tecido para forro de calçado é o carro chefe da empresa, principalmente em Kettenstull ou circular.

As principais matérias primas utilizadas são poliéster, elastano e poliamida, em ordem decrescente de importância para a empresa. O entrevistado cita que o elastano tem estado forte nos últimos anos, principalmente para o calçado do público feminino, ao utilizar malharia circular com elastano nos cabedais. Além disso outras modas, reintroduzem outros tipos de fios, como o metalizado Lurex ${ }^{\circledR}$.

Segundo o entrevistado, as tecnologias mais recentes, como os tecidos para utilização do cabedal pronto, estilo "Nike ${ }^{\circledast ", ~ e ́ ~ f e i t o ~ n o ~ m e s m o ~ m a q u i n a ́ r i o ~ q u e ~ j a ́ ~ e x i s t e ~ h a ́ ~ a l g u m ~ t e m p o ~}$ na empresa, a variação ocorre no produto, de acordo com o cliente (Figura 68). A diferenciação entre tecidos depende dos fios utilizados; da regulagem de máquina para travar o tecido, como no fechamento de pontos no tear; do acabamento na rama (máquina com aquecimento para estabilização do tecido), que pode deixar o tecido mais duro por calor; e da exigência em testes físicos de cada cliente, condição que torna o desenvolvimento mais extenso, pois necessita atingir as normas em propriedades físico-químicas. 
Figura 68 - Desenvolvimento de gáspea sob medida para cliente em circular jacquard

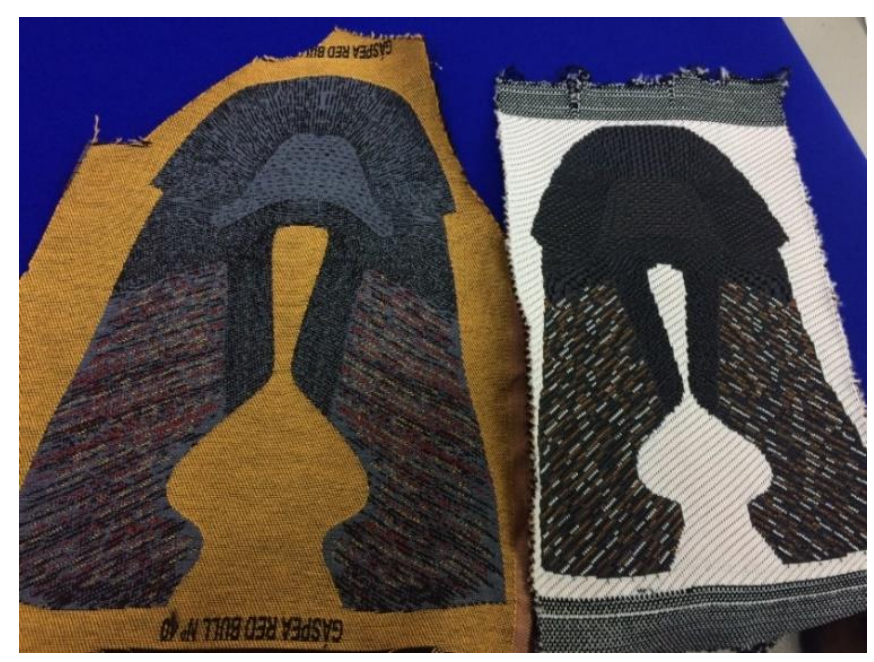

Fonte: (Lais Kohan, 2020)

O entrevistado, fez questão de ressaltar sobre a tecnologia de gáspea pronta, por ser diferente, na montagem dos calçados nos fabricantes nacionais, e ainda por eles não terem tanto domínio técnico dessa tecnologia. Infelizmente esse processo acaba sendo pouco viável, pois os clientes têm perda de cerca de $20 \%$, devido à dificuldade no corte, na variedade de numeração, por problemas de dimensionamento no acabamento do tecido e, então, torna-se mais prático a venda do tecido corrido.

Há projetos com utilização de fios reciclados, como fio Repreve® de poliéster reciclado, o entrevistado afirmou: "A empresa lança moda também”, ao descrever esses projetos diferenciados, pois como apontou: “eles são pioneiros no segmento". Inclusive, há quatro tecidos em linha de produção com fios reciclados, e também projetos com o fio Emana ${ }^{\circledR}$ (fio da empresa Rhodia, para vestuário, com biocerâmica incorporada na fibra, emanando radiação infravermelho, a qual atua no estímulo de circulação de sangue e na redução da celulite).

\section{Empresa E - Fabricante de compostos de PVC}

A empresa E é uma indústria fabricante de compostos para solados, em matéria prima de PVC transparente (cristal) e fosco, copolímero de acrilonitrilo e de butadieno, mais conhecida como borracha nitrílica (NBR) e borracha natural sintética (NR). Tem porte médio, atua no setor desde 2001 e faz parte de uma das cinco maiores empresas do segmento, com faturamento anual (2018) de 90 milhões de reais. 
O principal produto é o composto de PVC, em formato de pellets, com diversas formulações, em que clientes irão transformar, por processo de injeção em formas, para desenvolver os solados. Além de compostos, faz-se perfil, que são viras e faixetes, que são laminados calandrados estreitos, utilizados para acabamento de bolsas e calçados.

A atuação da empresa dentro do campo da sustentabilidade foi apontada pela entrevistada, relacionado ao material, em que utiliza o plastificante de óleo vegetal, já faz um tempo, e que a escolha foi motivada pela dificuldade de compra do tradicional, uma vez que grande parte dele é importado. Hoje em dia, uma tecnologia que apareceu há poucos anos é a esterificação do óleo de soja epoxidado, sendo que houve muita evolução neste tipo de matéria prima e este produto tem ótimas performances como plastificantes primários.

Outra matéria prima de origem natural é o carbonato de cálcio, porém, atualmente, pouco se utiliza. As fibras vegetais estão sendo empregadas, mais recentemente, com conceito estético, embora devido muito mais ao apelo sustentável e ainda porque muitas delas são resíduos. O lançamento desses materiais foi feito em 2019, na feira Fimec (de componentes de calçados, realizadas em Novo Hamburgo-RS), com madeira e com cortiça; depois, no Inspiramais, em julho, houve o lançamento dos compostos com fibra de cana de açúcar, bambu e coco. Existe a percepção que há precauções que devem ser feitas com as fibras, pois podem apresentar problemas pela variação de umidade e comprimento, que já foram resolvidos com os fornecedores e homologado um padrão.

Houve o questionamento sobre a possibilidade de tornar o PVC oriundo de um biopolímero. A entrevistada debateu que o polímero do PVC ainda é de origem do petróleo, mas já existe conhecimento para produzi-lo a partir do álcool etílico, porém ainda não é viável economicamente, principalmente para o fabricante da resina.

A questão de controle de resíduos dentro da fábrica é simplificada, devido ao PVC ser 100\% reciclável, assim, dentro da empresa, há a baixa emissão de resíduos e efluentes.

A sugestão da entrevistada para melhoria da sustentabilidade no setor seria fazer o ciclo reverso, uma vez que é possível reciclar o PVC, pois, conforme relatou a entrevistada - "no Brasil se recicla muito mais metal do que plástico, a reciclagem do metal chega a $80 \%$ e do plástico, uma quantidade bem inferior em $9 \%$ ou $10 \%$, quando muito". 


\subsection{Selo "Origem Sustentável” e sua contribuição para o setor}

\subsubsection{Estrutura do selo "Origem Sustentável”}

O selo "Origem Sustentável” foi lançado em 2013, conjuntamente com as associações setoriais, de fabricante de calçados (Abicalçados) e de componentes (Assintecal) (CARVALHO et al., 2014). Atualmente, a instituição que faz treinamento junto às empresas sobre o selo é o Instituto by Brazil (IBB), que também é parceiro das associações do segmento, cujo responsável participou desde a criação do selo referência.

O selo foi desenvolvido com o objetivo de melhorar o engajamento das empresas sobre as questões da sustentabilidade, além de auxiliar na ampliação das oportunidades de exportação e alinhar a indústria de calçados e componentes com as iniciativas nacionais e internacionais de certificações. Essa última foi o ponto de partida para o desenvolvimento do selo, com algumas certificações e requisitos globais, como os Objetivos de Desenvolvimento Sustentável da ONU, juntamente com programas e selos internacionais (Indicadores Ethos ${ }^{2}$ e OEKO-TEX ${ }^{3}$ ). A certificação também pode auxiliar na gestão empresarial como um como um todo, ao distinguir o que ocorre internamente nos processos, como através das ações reativas diante de problemas de não conformidades, além do envolvimento de funcionários e lideranças. Salienta-se também que não é marketing, e o que deve ser evidenciado são as ações tomadas da empresa (ORIGEM SUSTENTÁVEL, 2019).

O selo é formado por quatro dimensões principais: econômica, social, ambiental e cultural; mais a gestão da sustentabilidade, que atravessa todas essas outras, para garantir inclusão na estratégia do negócio da empresa. Para cada dimensão, há diversos critérios (Anexo B) e, dentro deles, há um total de 124 indicadores. O cumprimento dos indicadores irá definir a pontuação da empresa e o nível da certificação. Atingindo $50 \%$ deles, atende ao critério bronze, $75 \%$, prata, $90 \%$, ouro, e 100\%, diamante; porém, há uma pontuação mínima, em 32 indicadores, que são obrigatórios.

A gestão da sustentabilidade (Quadro 7) deve ser seguida e recomenda-se que a alta liderança da empresa participe, assim como ela deve disponibilizar recursos, documentar os

\footnotetext{
${ }^{2}$ Os Indicadores Ethos são uma ferramenta de gestão que visa apoiar as empresas na incorporação da sustentabilidade e da responsabilidade social empresarial (RSE) em suas estratégias de negócio. www.ethos.org.br/conteudo/indicadores/\#.XhXwCVVKjDc

${ }^{3}$ OEKO-TEX® é uma associação de 18 institutos de pesquisa e teste independentes no campo da ecologia têxtil e do couro na Europa e no Japão, com escritórios de contato em mais de 60 países. Os institutos parceiros têm responsabilidade conjunta pelo desenvolvimento de métodos de teste. https://www.oeko-tex.com/en/aboutus/oeko-tex
} 
procedimentos, de acordo com objetivos e metas a serem cumpridos e buscar a melhoria com base nos resultados (ORIGEM SUSTENTÁVEL, 2019).

Quadro 7 - Dimensão da Gestão da Sustentabilidade do selo Origem Sustentável

\begin{tabular}{|c|c|}
\hline \multicolumn{2}{|r|}{ Gestão da Sustentabilidade } \\
\hline Critérios & Descrição \\
\hline Política de Sustentabilidade & $\begin{array}{l}\text { Estabelecida pela alta direção e definir o comprometimento da } \\
\text { empresa com as } 4 \text { dimensões do selo, a partir de objetivos e } \\
\text { metas. }\end{array}$ \\
\hline Informação documentada & $\begin{array}{l}\text { Implementação e operação do sistema de gestão precisam estar } \\
\text { sistematizadas e documentadas. Documentos estabelecem os } \\
\text { procedimentos da empresa. }\end{array}$ \\
\hline Liderança e comprometimento & $\begin{array}{l}\text { Alta direção deve demonstrar liderança e comprometimento, } \\
\text { inclusive prover recursos para estabelecimento, implementação, } \\
\text { manutenção e melhoria contínua. }\end{array}$ \\
\hline $\begin{array}{l}\text { Monitoramento, medição, análise e } \\
\text { melhoria }\end{array}$ & $\begin{array}{l}\text { Este critério garante se sustentabilidade está incorporada no dia- } \\
\text { a-dia da empresa. Baseado no ciclo PDCA - plan (planejado), do } \\
\text { (implementados), check (verificados), act (tomada de ações) } \\
\text { com base nos resultados. }\end{array}$ \\
\hline
\end{tabular}

Fonte: Adaptado de (ORIGEM SUSTENTÁVEL, 2019, p.18)

O processo de adoção é iniciado pela empresa interessada, que deve entrar em contato com a entidade, a qual é regida (Assintecal ou Abicalçados). Assina-se um contrato e paga-se uma taxa e a empresa recebe o Manual da Metodologia. Caso a empresa precise de treinamentos sobre o funcionamento do selo, ela contrata a equipe do Instituto By Brasil para fazer esse serviço (pago por horas contratadas). Assim que ela estiver pronta para ser auditada, deve enviar os relatórios, e a empresa responsável pela auditoria (Senai ou SGS Brasil https://www.sgsgroup.com.br/) marcará a visita para fazer o processo de auditoria, que também é pago (por dia) e, após finalização, é emitido um relatório.

Para dar início à auditoria, a empresa precisa fornecer os seguintes documentos: CNPJ, pessoa para contato, Licença Ambiental (estadual/municipal), Licença Ambiental Federal (expedido pelo IBAMA), Alvará de funcionamento (prefeitura), nível de certificação pretendido e escopo da certificação. Caso não tenha algum documento, a empresa precisa apresentar uma justificativa. "No escopo da certificação devem ser definidos os processos ou serviços que serão foco da auditoria e que serão abrangidos pela certificação" (ORIGEM SUSTENTÁVEL, 2019, p.11). 
Depois de notificada para a auditoria, a empresa responsável terá o prazo máximo de 30 dias para agendar a inspeção para ir ao local e verificar todos os Requisitos de Sustentabilidade do Programa. O relatório final pode variar entre: aprovação plena para o nível pretendido, aprovação com tratamento de não conformidades para o nível pretendido, ou também aprovação inferior ou superior com ou sem tratamento de não conformidade ou não aprovação para a certificação. Caso a empresa for apontada com a não-conformidade, ela precisa propor ações corretivas e ela tem um prazo de no máximo 45 dias, se não for atendido no prazo, poderá ocorrer o cancelamento da certificação (ORIGEM SUSTENTÁVEL, 2019).

Depois de dois anos ocorre a nova auditoria para recertificação, o processo se repete, novamente, em que a empresa precisa atribuir na documentação o nível da certificação pretendida, o procedimento é o mesmo da auditoria regular, inclusive no tratamento das não conformidades.

\subsubsection{Resultado entrevista com a responsável do Instituto by Brazil}

\subsubsection{Construção do selo “Origem Sustentável” e adesão das empresas}

A entrevista foi realizada com a srta. Linda Pienis, coordenadora de Projetos de Inovação do Instituto by Brazil, em que dados completos estão no Apêndice D. A entrevistada teve participação, desde o início, durante a elaboração do selo Origem Sustentável, mas atualmente, o instituto atua na prestação de serviços, junto às empresas aderentes ao programa, para dar consultoria sobre o funcionamento, de acordo com a necessidade de horas acordadas com a empresa solicitante.

O selo entrou em vigor em 2013 e passou por uma revisão, depois de quatro anos, que já havia sido planejada inicialmente. Em 2017, foi contratada uma consultoria para a atualização, mas conforme dados da entrevista, não houve somente uma revisão, mas uma reformulação, tornando-o muito mais exigente, como salientado pela entrevistada - "uma vez também que as empresas do setor já estavam mais maduras, precisavam se readequarem à nova realidade".

O selo de 2013 “era bastante frágill, mas foi decidido iniciá-lo dessa forma, com o intuito de atrair a participação do maior número de empresas, uma vez que, quando a fabricante de calçados ou de componentes já aceitava participar do programa, já obtinha o selo branco. Para passar para o nível seguinte, era necessário somente atingir uma pontuação, mediante uma 
auto declaração, ao responder 52 questões sobre os quatro pilares (econômico, social, ambiental e cultural), e a partir das respostas, era determinado a conquista do nível seguinte, o bronze. Porém, para atingir os níveis superiores em prata, ouro ou diamante, tornava-se necessário auditoria externa (KOHAN et al., 2020).

Ao explicar o que compõem as quatro dimensões do selo, a entrevistada relatou alguns pontos, cujas empresas já estavam bem avançadas e outros, que foram sendo trabalhados no processo de adoção. Na dimensão social e ambiental, foram apontadas que as leis brasileiras já eram bem rígidas; sendo que, no caso da primeira, envolvem principalmente questões da segurança do trabalho e do cumprimento das leis trabalhistas; e na segunda, grande parte do que foi exigido já são obrigatórios por leis e licenças ambientais, de modo que tais requisitos já são necessários para as empresas funcionarem. Por outro lado, a questão econômica enfatiza os benefícios financeiros com a aplicação do programa, conseguir mecanismos para obter a economia, de água por exemplo; e por último, na dimensão cultural, explorar a cultura regional e o modo de fazer, próprio da empresa (KOHAN et al., 2020).

Em adição à dimensão ambiental, a última versão do selo incluiu o controle das substâncias tóxicas (Quadro 8) no monitoramento, junto aos fornecedores, e a necessidade de ensaios comprobatórios. Sobre esse tema, o Senai do calçado (Novo Hamburgo, RS) lançou um programa para reduzir o custo de testes para o segmento calçadista e abriu um curso informativo (SENAI, 2020). Também houve, nessa dimensão, a ampliação das documentações na gestão de resíduos sólidos, conforme relata a entrevistada, e houve ainda a inclusão de conceitos de economia circular, além da necessidade das empresas encontrarem outras possibilidades de destino, "do que se poderia melhor aproveitar antes de virar lixo", ou seja, reciclagem, reuso, ou geração de energia, como alternativa aos aterros. 
Quadro 8 - Lista de substâncias restritas aplicadas nos componentes de calçados

\begin{tabular}{|c|c|c|c|c|c|c|c|c|c|c|c|}
\hline & \multirow{2}{*}{ Substâncias } & \multicolumn{10}{|c|}{ Componentes } \\
\hline & & $\mathrm{C}$ & $\mathrm{T}$ & LM & MP & $\mathrm{MC}$ & $\mathrm{CM}$ & PQ & AV & A & $\mathrm{E}$ \\
\hline 1 & Alquilfenóis (NP, OP) e Alquilfenóis Etoxilados & $\mathrm{x}$ & $\mathrm{x}$ & $\mathrm{x}$ & $\mathrm{x}$ & $\mathrm{x}$ & & $\mathrm{x}$ & $\mathrm{x}$ & $\mathrm{x}$ & $\mathrm{x}$ \\
\hline 2 & Azo Corantes & $\mathrm{x}$ & $\mathrm{x}$ & $\mathrm{x}$ & & & & $\mathrm{x}$ & $\mathrm{x}$ & $\mathrm{x}$ & \\
\hline 3 & Clrofenós & $\mathrm{x}$ & $\mathrm{x}$ & & & & & & & & \\
\hline 4 & Compostos Orgânicos Voláteis (VOCs) & & & & & & & $\mathrm{x}$ & & & \\
\hline 5 & Crômio 6 & $\mathrm{x}$ & & & & & & & & & \\
\hline 6 & Formaldeído & $\mathrm{x}$ & $\mathrm{x}$ & & & $\mathrm{x}$ & & $\mathrm{x}$ & $\mathrm{x}$ & $\mathrm{x}$ & $\mathrm{x}$ \\
\hline 7 & Dimetilfumarato & & & & & & & & & & $\mathrm{x}$ \\
\hline 8 & Ftalatos & $\mathrm{x}$ & & $\mathrm{x}$ & $\mathrm{x}$ & & & $\mathrm{x}$ & $\mathrm{x}$ & $\mathrm{x}$ & $\mathrm{x}$ \\
\hline 9 & $\begin{array}{l}\text { Metais Pesados Totais (Arsênio, Cádmio, } \\
\text { Chumbo e Mercúrio) }\end{array}$ & $\mathrm{x}$ & $\mathrm{X}$ & $\mathrm{x}$ & $\mathrm{x}$ & $\mathrm{x}$ & $\mathrm{x}$ & & $\mathrm{x}$ & $\mathrm{x}$ & \\
\hline 10 & Organoestanhos & & & $\mathrm{x}$ & $\mathrm{x}$ & & & $\mathrm{x}$ & $\mathrm{x}$ & $\mathrm{x}$ & \\
\hline 11 & $\begin{array}{l}\text { Hidrocarbonetos Aromáticos Policíclicos (PAHs) } \\
\text { Solventes residuais (DMFa, DMAC, NMP e }\end{array}$ & & & $\mathrm{x}$ & $\mathrm{x}$ & & & $\mathrm{x}$ & $\mathrm{x}$ & $\mathrm{x}$ & \\
\hline 12 & Formamida) & & & $\mathrm{x}$ & $\mathrm{x}$ & & & $\mathrm{x}$ & & $\mathrm{x}$ & \\
\hline 13 & Liberação de níquel (Ni) & & & & & & & & $\mathrm{x}$ & & \\
\hline 14 & Corantes dispersos & & $\mathrm{x}$ & & & & & & & & \\
\hline
\end{tabular}

Fonte: Adaptado de (SENAI, 2020) (KOHAN et al., 2020)

Na primeira versão, o selo chegou a ter 150 adesões, declarado pela entrevistada. Enquanto na nova, poucas empresas tinham se certificado, uma vez que o lançamento havia sido recente em julho de 2019; também, pelo fato de a entrevista ter sido realizada em dezembro de 2019, quando havia apenas cinco empresas já certificadas. Contudo, mais de 45 já tinham assinado o termo de compromisso e estavam em processo de preparação.

\subsubsection{Visão sobre a contribuição do selo para o setor}

Para a entrevistada, o selo teve uma relevante importância na exportação, pois houve interesse desde o início, por ocasião do no lançamento do selo Origem Sustentável, de empresas que já exportavam, inclusive uma das primeiras empresas certificadas foi um fabricante de calçado infantil, que precisava de suporte à exportação, sendo um segmento muito rígido, com normas estritas quanto à comprovação das substância contidas. A entrevistada declarou que, justamente, essa empresa, depois da aquisição do selo, passou a exportar para o mercado chinês e "foi a sustentabilidade que abriu as portas".

Além do mais, as empresas calçadistas brasileiras exportadoras vinham sofrendo com a questão da substância restrita, com toda documentação necessária da declaração da origem da 
matéria prima, que deve ser testada, de acordo com a cartilha do cliente ou do país comprador. Com isso, a entrevistada indicou que o selo acabou sendo mais um diferencial de credibilidade para as empresas exportadoras. Sobre a testagem para comprovação dos produtos, o Senai do Calçado (Novo Hamburgo, RS) lançou um acordo de cooperação com a cadeia calçadista para aderirem a um plano de parceria, que reduziria o custo da testagem e haveria cursos e informações disponíveis para os fabricantes sobre as substâncias restritas (SENAI, 2020).

Entre os benefícios propiciados com a adoção do selo, apontado pela entrevistada, um dos destaques foi à economia de insumos, durante o processo produtivo, relacionados com a adoção de parâmetros de monitoramento, por todos os setores das empresas, e uma documentação mais completa, uma vez que antes, era somente o departamento da Segurança do Trabalho que encabeçava essas funções dentro das empresas. Com a nova metodologia necessitou-se o envolvimento do " $\mathrm{RH}$, junto o econômico, o financeiro; trabalhando juntos e fazendo um controle sistematizado, que começou a demonstrar os ganhos", como aponta a entrevistada.

Mesmo assim, ainda há dificuldades para adquirir novos membros na cadeia para a certificação, a entrevistada apontou que os motivos ainda estão relacionados à falta de prioridade das empresas, dentro do tema da sustentabilidade. Elas ainda questionam os ganhos reais com à adoção, apontando que é necessário investir internamente, ao destinar pessoas específicas para à gestão da sustentabilidade e que esse custo extra não será possível inserir no preço de venda do produto. Apesar disso, a entrevistada apontou mudanças ocorrendo em 2019, em relação às iniciativas de alguns acordos de cooperação, exemplificou com o caso de uma grande marca nacional, "uma das maiores", que, inclusive, está presente nos shoppings centers, que está exigindo o Selo Origem Sustentável para todos os seus fornecedores. Com isso, ela declarou a mudança de posicionamento: "eles (os fornecedores) vêm correndo; antes, a gente tinha que bater na porta e insistir, agora, a demanda está meio espontânea”.

6.2.2.3. O impacto da sustentabilidade na cadeia brasileira de calçados segundo o IBB

A entrevistada, srta. Linda Pienis, reportou que, apesar das dificuldades, apresentadas anteriormente, há uma mudança que estava ocorrendo (em 2019) no setor, quanto ao envolvimento muito maior com o tema da sustentabilidade, que impactou inclusive a palestra (“Sustentabilidade: é hora de avançar"), que atraiu muito mais pessoas, que as associações esperavam, e tiveram que limitar as inscrições à capacidade do auditório (400 pessoas). 
Além disso, enfatizou o surgindo no mercado de muitas empresas com viés sustentável, em vários nichos, como sapato vegano ou o sapato sem as substâncias restritas, em que, de fato, estão sendo lançados tais propostas de negócio no mercado nacional. Somados a isso, houve o enfoque nas diversas matérias primas naturais dos tecidos e uma valorização geral dos materiais: orgânicos, reciclados, plásticos vindos do amido, como da mandioca. Houve inclusive uma compilação desses fornecedores sustentáveis, a partir de um guia virtual dos fornecedores.

No fim, quando perguntada sobre a questão de reciclagem do calçado, a respondente apontou que ainda é um problema, mas descreveu que houve uma iniciativa de marca calçados infantis para fazer a logística reversa, isto é fazer a devolução na loja, após o uso. Infelizmente a iniciativa não teve continuidade, pelo fato apontado de que "o calçado no Brasil passa de mão em mão até perder valor" e "o último usuário não teria condições de entregar dentro da loja". Ainda salientou que, dentro da fábrica de calçados esportivos, onde se trabalha com polímeros injetados, é possível recuperar ou reciclar grande parte dos componentes.

6.2.3. Apresentação do selo Origem Sustentável na palestra "Sustentabilidade: é hora de avançar"

A palestra "Sustentabilidade: é hora de avançar" ocorreu no dia 23 de novembro de 2019, em Campo Bom, Rio Grande do Sul, organizado pelo Inspiramais, Abicalçados, IBB e CICB (Centro das Indústrias de Curtumes do Brasil), cuja programação encontra-se no Anexo C. No evento, houve a presença de 400 expectadores, principalmente fabricantes de calçados e de componentes. Dados contidos nesse texto foram coletados por anotações e fotografias, durante o evento.

No início do evento, após a abertura, o CEO da Arezzo, Alexandre Birman, discursou e enfatizou o trabalho em conjunto da cadeia e da necessidade do "certificado de origem, palavrachave hoje da consumidora é saber sobre quem fez e quais as condições de trabalho, aquela pessoa teve e qual o ambiente de trabalho aquela pessoa trabalhou. Quais são as regras, quais são as condições de segurança e de onde vieram as matérias primas". E pediu uma união da cadeia para concretização do selo nas empresas do setor.

Outro destaque no evento foi a apresentação da empresa Renner, que mostrou os resultados positivos do último ano (2018) em: receita bruta (11,4 bilhões de reais), número de lojas (570), colaboradores (21,4 mil), valorização das ações (5.000\% desde 2005). Além disso, 
apresentou a atuação na sustentabilidade, através de certificações e logística reversa, no recolhimento de roupas usadas no varejo.

Apresentaram-se os benefícios do selo por algumas empresas, em relação à dimensão ambiental. O tema abordado, como pode ser visto no Quadro 9, é relativo à economia de matérias primas, como água e energia, além de reciclagem e uso de fonte renovável. Essas informações é uma forma de incentivar os participantes presentes e mostrar o retorno financeiro.

Quadro 9 - Benefícios obtidos com a obtenção do selo Origem Sustentáveis, por fabricantes do setor calçadista brasileiro

\begin{tabular}{|c|c|c|c|}
\hline Nível & Empresa & Tipo & Benefícios do selo \\
\hline Ouro & $\begin{array}{l}\text { Vulcabrás } \\
\text { Azaleia }\end{array}$ & $\begin{array}{l}\text { Fabricante de } \\
\text { Calçado }\end{array}$ & $\begin{array}{l}95 \% \text { de economia de água tratada e } 25 \% \text { do total, } 10 \% \\
\text { redução no volume de efluentes descartados, } 15 \% \text { de } \\
\text { redução no uso de matéria prima, } 25 \% \text { de redução na } \\
\text { geração de resíduos }\end{array}$ \\
\hline Ouro & Cipatex & $\begin{array}{l}\text { Fabricante de } \\
\text { Laminado }\end{array}$ & $\begin{array}{l}100 \% \text { dos resíduos gerados são triados, tratados e } \\
\text { encaminhados para reciclagem ou destinação correta, } 50 \% \\
\text { de economia da água, uso de matérias-primas de fonte } \\
\text { renovável. }\end{array}$ \\
\hline Diamante & Bibi & $\begin{array}{l}\text { Fabricante de } \\
\text { Calçado }\end{array}$ & $\begin{array}{l}20 \% \text { de redução na conta de energia, contratação de energia } \\
\text { elétrica oriunda de fontes sustentáveis, } 62 \% \text { de aumento na } \\
\text { utilização de adesivo à base d'água, redução de resíduos } \\
\text { industriais, desenvolvimento de produto sem toxidades } \\
\text { (substâncias restritas) }\end{array}$ \\
\hline
\end{tabular}

Fonte: (Lais Kohan, Palestra “Sustentabilidade é hora de avançar”, 2020)

6.2.4. Dados obtidos a partir das duas entrevistas com empresas que implantaram o selo Origem Sustentável

Nesta etapa, foram realizadas duas entrevistas com o foco de compreender os resultados adquiridos pela implantação do selo "Origem Sustentável”, diante das mudanças internas, benefícios adquiridos (Quadro 10) e as ações na gestão de resíduos dentro dessas empresas (Quadro 11). O resultado comparativo sobre a implantação do selo é apresentado abaixo, na qual há características em comum, quando relaciona-se ao trabalho em conjunto feito pelos funcionários em: cooperação, entre setores envolvendo "gestores" ou criando "cultura" para manutenção contínua, a longo prazo e destinação correta de resíduos (Quadro 10). 
Quadro 10 - Resultados das entrevistas sobre a implantação do selo Origem Sustentável

\begin{tabular}{|c|c|c|}
\hline \multicolumn{3}{|c|}{ Implantação do Selo "Origem Sustentável" } \\
\hline Assuntos & Empresa F & Cipatex \\
\hline $\begin{array}{l}\text { Classificação no selo } \\
\text { (1a versão) }\end{array}$ & Ouro & Ouro \\
\hline $\begin{array}{l}\text { Nova versão } \\
\text { (dezembro, 2019) }\end{array}$ & Em processo & Em processo \\
\hline $\begin{array}{l}\text { O que motivou a } \\
\text { implantação? }\end{array}$ & $\begin{array}{l}\text { 1)Abertura de novos mercados, como na } \\
\text { exportação (controle na captação da } \\
\text { matéria prima) }\end{array}$ & $\begin{array}{l}\text { 2)Parceria com a Assintecal, foi feito um } \\
\text { teste piloto na empresa (primeira a } \\
\text { implantar) }\end{array}$ \\
\hline $\begin{array}{l}\text { Fornecedores } \\
\text { precisaram se } \\
\text { readequar? }\end{array}$ & $\begin{array}{l}\text { 1)Passaram a responder um questionário 2) } \\
\text { Precisaram absorver o custo de testes das } \\
\text { substâncias restritas para exportação. }\end{array}$ & $\begin{array}{l}\text { 3) Fornecedores precisaram substituir } \\
\text { matérias primas, devido a novas demandas } \\
\text { de produto (sem metal pesado, sem ftalato) }\end{array}$ \\
\hline $\begin{array}{l}\text { Mudanças internas } \\
\text { para ajustar aos } \\
\text { critérios do selo. }\end{array}$ & $\begin{array}{l}\text { 1)Criação de comitê de sustentabilidade 2) } \\
\text { Capacitação da equipe e gestores de cada } \\
\text { área 3) Assessoria ambiental (externa) }\end{array}$ & $\begin{array}{l}\text { 4)Criar a cultura para a manutenção } \\
\text { contínua das ações (limpeza) 5) Projetos } \\
\text { internos (redução de água e energia) }\end{array}$ \\
\hline Benefícios do Selo & $\begin{array}{l}\text { 1)Cultura da "sustentabilidade (longo } \\
\text { prazo) 2) Redução de insumos } 3 \text { ) } \\
\text { Destinação de resíduos (25\% aparas de } \\
\text { sintéticos reaproveitadas) 4) Meta anual } \\
\text { (auditoria) }\end{array}$ & $\begin{array}{l}\text { 1)Cultura da "sustentabilidade" (longo } \\
\text { prazo) 2) Redução de insumos ( } 50 \% \text { água, } \\
\text { descartáveis) 3) Destinação de resíduos 5) } \\
\text { Insumos mais sustentáveis (ex: Vegan) 6) } \\
\text { Funcionários trazem soluções 7) Fábrica } \\
\text { mais limpa e organizada }\end{array}$ \\
\hline Dificuldades & $\begin{array}{l}\text { 1)Fornecedores com matérias primas } \\
\text { sustentáveis não conseguem preço tão } \\
\text { competitivos }\end{array}$ & $\begin{array}{l}\text { 2) Coleta de dados inicial de cada setor } 3 \text { ) } \\
\text { Funcionários mais antigos ainda são } \\
\text { resistentes à mudança }\end{array}$ \\
\hline Próximas ações & $\begin{array}{l}\text { 1)Meta anual 2) Encontro com } \\
\text { fornecedores (2020) sobre a política da } \\
\text { empresa. }\end{array}$ & $\begin{array}{l}\text { 3) Desenvolvimento de certificação interna } \\
\text { (todos setores, além do calçado) 4) } \\
\text { Adequação para Origem Sustentável }\end{array}$ \\
\hline
\end{tabular}

Fonte: (Lais Kohan, 2020)

Quadro 11 - Ações realizadas sobre a Gestão de Resíduos das empresas entrevistas

\section{Ações sobre a Gestão de Resíduos}

\begin{tabular}{|c|c|c|}
\hline Assuntos & Empresa F & Cipatex \\
\hline $\begin{array}{l}\text { Ações reuso, } \\
\text { reciclagem, geração } \\
\text { de energia ou } \\
\text { descarte }\end{array}$ & $\begin{array}{l}\text { Empresa faz a logística reversa, } \\
\text { reutilização, reciclagem e o } \\
\text { coprocessamento ( } 75 \% \text { dos resíduos } \\
\text { gerados). Há o interesse em trabalhar } \\
\text { com a pirólise. }\end{array}$ & $\begin{array}{l}\text { Trabalho de engenharia reversa é feito } \\
\text { internamente. Vende-se resíduos para } \\
\text { reciclagem e reuso (mais de } 20 \text { tipos). } \\
\text { Para geração de energia, há estudos em } \\
\text { andamento. }\end{array}$ \\
\hline Eco design o & $\begin{array}{l}\text { Entrevistada não tem informação sobre } \\
\text { outros setores da empresa }\end{array}$ & $\begin{array}{l}\text { Processo já é maduro, não se consegue } \\
\text { reduzir. }\end{array}$ \\
\hline $\begin{array}{l}\text { Sustentabilidade no } \\
\text { Produto }\end{array}$ & $\begin{array}{l}\text { Substituição do couro por laminado } \\
\text { sintético (1996), dados recentes a } \\
\text { entrevistada não tinha informação. }\end{array}$ & $\begin{array}{l}\text { PVC contém } 57 \% \text { de sal marinho. Há a } \\
\text { tecnologia nova de uso de plastificante } \\
\text { vegetal, mas preço depende do mercado } \\
\text { da nacional da soja. }\end{array}$ \\
\hline $\begin{array}{l}\text { Ações após uso do } \\
\text { calçado }\end{array}$ & $\begin{array}{l}\text { Faltam leis impondo a logística reversa } \\
\text { dos calçados. Na embalagem há a } \\
\text { parceria com a startup "Eu Reciclo" }\end{array}$ & $\begin{array}{l}\text { Empresas e Universidades estudam } \\
\text { reciclagem, necessita-se de equipamentos } \\
\text { e pessoas especializadas para distinguir } \\
\text { os componentes. }\end{array}$ \\
\hline Sugestões & $\begin{array}{l}\text { Estruturar a sustentabilidade na } \\
\text { organização, para que diversos projetos } \\
\text { sejam continuamente gerados e traga } \\
\text { diferencial competitivo. }\end{array}$ & $\begin{array}{l}\text { Há necessidade de organização e união } \\
\text { na cadeia. Temos o exemplo da } \\
\text { Vinylplus na Europa que desde } 2010 \\
\text { estipula metas de reciclagem. }\end{array}$ \\
\hline
\end{tabular}


Uma questão importante, que foi reforçada com a nova versão do selo, foi a gestão de resíduos, cujo indicador é um requisito obrigatório, sendo assim, pôde ser confirmado por ambas as empresas ao reportarem sobre a necessidade de desenvolver soluções para redução dos maiores volumes de resíduos. Assim, elas apresentaram quais foram os desdobramentos internos para reaproveitar os resíduos; enquanto a empresa $\mathrm{F}$ trabalhou em parceria junto a um fornecedor e reinseriu as aparas no processo de laminados sintéticos no processo dele e, resultou na redução de 25\% das sobras; já a Cipatex estudou e testou a reintrodução das sobras de produção também no processo e, ainda tem planejamento em pesquisa, junto à universidades para aplicar resíduos aliados ao design de mobiliário.

Além da reinserção dos resíduos no processo produtivo das empresas e fornecedores, o que não foi possível reciclar, ambas encaminharam os materiais para fazer um destino mais adequado. Com isso, a Cipatex vende para outras empresas reciclarem e acompanham junto ao elas as medidas realizadas; a empresa F envia essas sobras para coprocessamento, que é o destino para geração de calor em fornos de clínquer (cimento).

Entretanto, soluções pró-ativas através do ecodesign ou na redução de processo não foram apresentadas mudanças recentes, devido ao fato, da entrevista da Empresa F não ter autorização para reportar sobre outros setores e, da Cipatex justificar que já houve mudanças anteriormente de readequação de processo e, atualmente, ele já é enxuto.

Sobre as soluções relacionadas à sustentabilidade do produto, a Empresa F apontou que uma grande mudança da empresa iniciou em 1996, quando ela decidiu substituir o couro por laminado de poliuretano, que foi uma mudança de cultura para o consumidor. Enquanto, a indústria de laminados de PVC, explicou que grande parte da matéria prima já é de origem em fonte renovável (sal marinho), mas aumentou-se a possibilidades de aditivos em base vegetal, motivado pelos problemas nocivos de parte dos plastificantes sintéticos e, também, com a proibição deles pela União Europeia, a partir do Registro, Avaliação, Autorização e Restrição de Produtos Químicos (REACH), o que necessitou de pesquisa em busca da substituição. O aditivos de base vegetal desenvolvido, que mais se adequou às propriedades de estabilidade no produto, foi o plastificante de óleo epoxidado de soja, em que foi aperfeiçoado ao longo do tempo e "já tornou-se possível sua utilização", como apontado pelo entrevistado, que 
problematizou também, "mas há o fator preço, pois ele varia no mercado brasileiro, dependendo da exportação de soja”.

No questionamento sobre a relação sobre a importância da implantação do selo "Origem Sustentável" em relação à exportação, houve respostas diferentes entre os entrevistados, em que uma das justificativas poderia ser atribuída ao tipo de produto que cada empresa desenvolve; cuja a Empresa F fabrica calçados, o que envolve diferentes matérias primas, dependendo do modelo de sapato e; enquanto a Cipatex manufatura laminados de PVC, mesmo havendo diferentes fornecedores, possivelmente a variedade é menor. Diante disso, a Empresa F apontou que o selo exigiu a maior transparência da origem da matéria prima, por conta disso, houve reflexo diretamente junto aos fornecedores, que reagiram com resistência quanto às mudanças, pela necessidade em substituição de matérias primas e de como aliar isso ao preço, além da necessidade em realizar a testagem para comprovação da isenção de substâncias restritas, de acordo com cada cliente internacional. Enquanto a empresa Cipatex não relacionou diretamente ao selo, a abertura de outros mercados, mesmo assim, a entrevistada apontou, que houve uma mudança, que poderia ter influenciado indiretamente, ao fato de que, houve o maior engajamento por todos os funcionários, o que poderia ter influenciado nas negociações externas. Mesmo assim, a entrevistada da Cipatex reafirma a importância do tema da sustentabilidade, inclusive, aponta "é realmente obrigatório o enquadramento na sustentabilidade para concretizar as exportações", que inclusive, na época da entrevista, a empresa estava exportando para os Estados Unidos.

Por fim, a questão logística reversa do calçado após o uso ainda não há soluções concretas, porém, como a Cipatex salientou: “já há pesquisas em andamento sobre maquinários e, para fazer a separação adequada seria necessário ter pessoas especializadas para distinguir os componentes", enquanto a Empresa F ressaltou a questão da responsabilidade governamental, que não cobra da sociedade soluções concretas, indicando que "não há leis ou regulamentos impondo essa questão".

Ao serem questionados pela pesquisadora, para darem sugestões sobre o que poderia ser implementado na cadeia nacional de calçados para a melhoria e ampliação da sustentabilidade no setor, a Empresa F alertou a necessidade de estruturar o tema dentro das organizações, que através de projetos poderia resultar em, inclusive, um diferencial competitivo. Enquanto a Cipatex, recomendou uma maior união da cadeia, em cada subconjunto, em soluções concretas e, para exemplificar, descreveu um projeto local, na União Europeia, o Vinylplus, que desde 
2010, definiu metas de reciclagem de PVC, em diversos períodos, desde sua criação, mostrando que isso seria possível, inclusive no Brasil.

\subsection{Pesquisa Laboratorial - formulação de solado de PVC com inserção de serragem de bambu}

\subsubsection{Etapa Preparatória}

\subsubsection{Disciplina - Processamento de Termoplástico}

A presente autora cursou a disciplina Processamento de Termoplástico (Pós-Graduação em Engenharia e Ciências de Materiais, Campus Diadema - Unifesp), no primeiro semestre de 2019.

Os principais tópicos dessa disciplina foram: estrutura e propriedades polímeros; processamento por extrusão e injeção de termoplásticos e outros como, calandra, misturador termocinético - Drais e outro, modelo Masterbatch ("panela misturadora") para fazer a prémistura (UNIFESP, [s.d.]).

A disciplina cursada "Processamento de Termoplástico" determinou toda a etapa preparatória, pois durante o semestre cursado realizaram-se diversas atividades; visitas às feiras, eventos, fichamentos sobre PVC e compósitos para solados e contato com especialistas do mercado.

\subsubsection{Viniltec - Conferência Tecnológica sobre o PVC no Brasil - 20.03.2020}

O evento da "Viniltec" ocorreu no auditório da Associação Brasileira de Indústria do Plástico (ABIPLAST em São Paulo - SP). A conferência durou um dia (8-17h) e estiveram presentes palestrantes acadêmicos e profissionais do mercado brasileiro de PVC.

Durante as palestras, houve um predomínio de temas sobre PVC rígido, principalmente, a matéria prima de tubulações (canos). Dentro da temática principal, o tema mais explorado, em diversas palestras, foi o uso do carbonato de cálcio. Carbonato de cálcio é aplicado como função no polímero, com o objetivo de melhoria das propriedades mecânicas e com baixo custo.

No evento, também, houve o contato com o sr. Emerson Madaleno da Braskem, que é a principal empresa fornecedora de resina de PVC no Brasil, que incentivou pesquisas com esse polímero e, inclusive, marcou uma visita ao laboratório (Plataforma Multiusuária de 
Processamento de Materiais Poliméricos da Unifesp, Diadema), a fim de explicar o processo produtivo.

\subsubsection{Plástico Brasil - 25.03.2019- São Paulo Expo}

"Plástico Brasil" é uma feira, que tem foco em apresentar os últimos avanços tecnológicos e as principais tendências globais dos segmentos que envolvem a cadeia produtiva do plástico. Centrada em maquinários de grande porte industrial e matérias primas, como resinas, moldes e automação industrial da cadeia produtiva do plástico (PLÁSTICO BRASIL, 2019). Na visita, foram vistos maquinários em escala real da indústria: perfis diferentes de extrusora, máquinas gigantes para produção de sacolas plásticas e diversos fornecedores de componentes de plástico.

6.3.1.4. Visita do sr. Emerson Madaleno (Braskem) ao laboratório Unifesp (campus Diadema) - 01.04.2019

A visita do profissional sr. Emerson Madaleno confirmou a possibilidade de uso dos maquinários do laboratório com resinas e formulações de PVC. Ele mostrou como utilizar a calandra como principal maquinário de incorporação de uma formulação de PVC flexível para solado. Por ter fácil manipulação, a calandra tem viabilidade para formular e, rapidamente, já possibilita visualizar o resultado. Ele ainda confirmou o que se tinha buscado em literatura, que, industrialmente, o processo produtivo do PVC é feito na extrusora, também existente no laboratório.

\subsubsection{Feiplastic}

Evento ocorrido em 22.04.2019, no Expo Center Norte (São Paulo - SP).

A Feiplastic é a feira internacional do plástico, realizada em São Paulo. O evento é direcionado aos profissionais do setor, principalmente, os transformadores do plástico, embalagens, indústria automotiva, alimentos, entre outros (FEIPLASTIC, 2020).

Para o setor calçadista, a feira oferece o contato com empresas fornecedoras de aditivos, que são compostos usados na formulação dos plásticos. Os principais tipos de aditivos são: plastificantes, lubrificantes, pigmentos, agentes expansores, estearatos e carga. 
Além do fornecedor de aditivos, há o fabricante de compostos, que desenvolvem as formulações de plástico, já prontas, e são comercializados em formatos de pellets (ou grânulos), feitos por extrusão. Esses pellets serão usados em processos de injeção para desenvolver as peças do calçado, cujo papel de transformação fica a cargo de empresas intermediárias, que fazem a injeção, ou indústrias calçadistas, normalmente, de grande porte, que possuem o maquinário necessário.

$\mathrm{Na}$ feira, houve o encontro novamente entre o grupo da disciplina (Processamento de Termoplásticos, Unifesp), com o sr. Emerson Madaleno, da empresa Braskem®. Ele fez indicações dos fornecedores, dentro da feira, do segmento de solados e informou uma formulação base (Tabela 15), de referência para escolha de aditivos e resina.

Tabela 15 - Formulação base para solado em PVC (Braskem)

\begin{tabular}{lc}
\multicolumn{2}{c}{$\begin{array}{c}\text { Formulação básica para solado de PVC } \\
\text { Dureza Shore A**: 60-80 }\end{array}$} \\
\hline Componente & $\begin{array}{c}\text { Quantidade (pcr*) } \\
\text { Resina }\end{array}$ \\
Plastificante & $50-80$ \\
Estabilizante térmico & $2-4$ \\
Lubrificante & $0,2-0,5$ \\
Óleo de soja epoxidado & $5-20$ \\
Carbonato de cálcio & $0-30$ \\
\hline \multicolumn{2}{c}{$*$ pcr = parte por cento de partes de resina (p/p) } \\
**Teste de Dureza conforme norma ASTM D2240 \\
\multicolumn{2}{c}{ Fonte: (Lais Kohan, 2020) }
\end{tabular}

A partir das indicações, houve o contato com a empresa Karina (site), fornecedora de compostos para solados, que doou um composto para fazer os testes laboratoriais. Optou-se pela escolha de formulação de um PVC transparente, flexível, sem carbonato de cálcio, pois como o intuito foi inserir uma fibra na formulação, a transparência poderia permitir a valorização visual no produto. Sobre as demais propriedades, seguiu-se a indicação da Braskem de uma formulação de Dureza Shore de 65 e densidade 22, ambos, parâmetros indicam a flexibilidade do solado. 
6.3.2. Definições para PVC e compósitos para solados

\subsubsection{Poli (cloreto de vinila) - PVC}

O policloreto de vinila é amplamente utilizado na indústria como um commodity do plástico, por ser versátil, com baixo custo e ainda ter resistência à abrasão. (ELNAGGAR; FATHY; HASSAN, 2019; WU et al., 2016). A presença do cloro (Figura 69) torna-o resistente à propagação de chamas, o que contribui para sua aplicação; ele também faz com que a estrutura molecular se torne polar, aumentando a vasta possibilidades de combinação de aditivos. Por isso, é utilizado em embalagens, brinquedos, acessórios médicos e solados; mas seu uso principal, em volume, é na construção civil, predominantemente, na matéria prima de tubulações de água. (RODOLFO JUNIOR; TSUKAMOTO, 2019).

Figura 69 - Fórmula estrutural do PVC

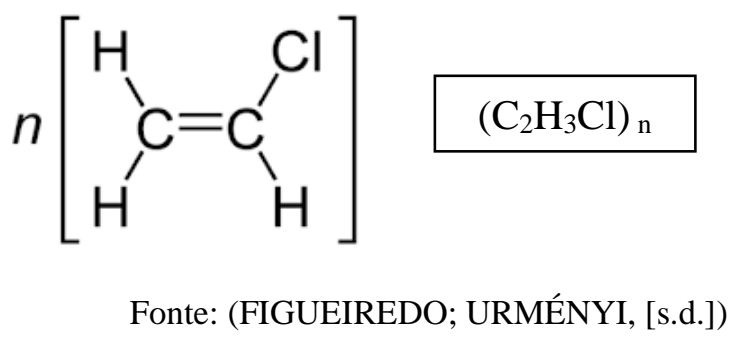

A resina de PVC contém de $57 \%$ de cloro, proveniente do sal marinho e o restante, do petróleo (eteno). Além da resina, para compor uma formulação é necessário a mistura com aditivos, que são usados para prover características específicas, como os produtos: estabilizantes (inibição de reações de degradação pelo calor, luz), lubrificantes (redução do atrito durante o processamento), cargas (redução de custos e alterações mecânicas), plastificantes (modificação dureza e flexibilidade), desmoldantes (facilitação para descolamento das paredes dos moldes) e agentes de expansão (formação de estrutura celular) (RODOLFO JUNIOR; TSUKAMOTO, 2019).

No mercado de moda, o PVC é aplicado em estruturas de laminado sintético, um revestimento plástico sobre tecido, que é utilizado no vestuário. Nos calçados, é utilizado o mesmo laminado, só que mais grosso e resistente, aplicado no cabedal; enquanto no solado, por processo de injeção, tem sido intensificado o uso, no Brasil, desse polímero, em que foi 
ilustrado a tendência de crescimento nos últimos anos (Tabela 10 no item 4.2.4) (GUIMARÃES, 2018).

Para obter a flexibilidade e durabilidade desejável, o PVC é misturado com diversos tipos de plastificantes, que atuam diminuindo as interações das forças de Van der Waals e intercalam a cadeia, tornando-o mais maleável. Os plastificantes são constituídos por ésteres, em ácidos alifáticos ou álcoois. Eles podem ser ramificados, o que os torna mais permanentes, ou lineares, que, por característica, reduzem a temperatura vítrea do polímero (NAVARRO et al., 2010; RABELLO, 2000). Outra característica é a sua ação na formulação, pois há os chamados plastificantes primários, que, normalmente, são mais baratos e utiliza-se em maior quantidade; e os secundários, que são usados para adicionar outras propriedades, como resistência à chama ou flexibilidade em baixas temperaturas (GODWIN, 2011).

A questão do PVC trouxe implicações mundiais, pois desde 2005, o Parlamento Europeu, sob o conselho do Registro, Avaliação, Autorização e Restrição de Produtos Químicos (REACH) impôs restrições aos produtos infantis plásticos contendo uma classe de plastificantes, os ftalados. Os principais ftalatos restringidos, limitados a $0,1 \%$ em peso, são: di- (2-etilhexil) ftalato (DEHP), ftalato de benzila e butilo (BBP), ftalato de dibutila (DBP), diisononil ftalato (DINP), ftalato di-isodecil (DIDP), ftalato di-n-octil (DNOP) (EUROPEAN PARLIAMENT, 2009).

Não são todos os plastificantes ftalatos que têm ação nociva ao homem. A estrutura química deles são de ésteres de ácidos ftálicos e contêm um anel benzênico ligado a dois grupos éster, mas somente a posição orto, que são os carcinogêncios. Dentre os plastificantes ftalatos nocivos, há ainda divisões pela massa molar dos tipos: baixo ftalato, com baixa massa molar (3 a 6 átomos de carbono), como DOP (di-2-etil-hexila) e DBP; e alto ftalato, contendo entre 7 e 13 átomos de carbono, como DINP, DIDP e DPHP. O DOP é o ftalato mais utilizado e com grandes quantidades na formulação do PVC, chegando entre $15-60 \%$ do peso (MATTANA, 2017). Porém, o que tornou-se um problema foi que por razões termodinâmicas, os plastificantes tendem a migrar para a superfície e provocam a perda progressiva das propriedades, assim, esses plastificantes nocivos foram proibidos, inicialmente, nos produtos plásticos infantis (NAVARRO et al., 2010).

Como alternativa aos ftalatos houve diversas iniciativas de como alterar o processamento do PVC, ao reticular e deixar o aditivo nas camadas inferiores da superfície (com peróxido, azidas, 10-12 sulfetos e acrilatos) (NAVARRO et al., 2010). Há também uma 
ampla gama de plastificantes substitutos, escolhidos, dependendo das propriedades requeridas: poliméricos, a partir poliéster, são alternativos por terem baixa volatilidade, mas ainda são caros; éster dibenzoato (primário ou secundário) indicado para revestimentos com resistência a UV; éster fosfato (resistentes à chama); ftalatos em posição "para”, como o DOTP (tereftalato de dioctilo), são permitidos e amplamente utilizados nos Estados Unidos, por exemplo. Outra classe de plastificantes que destaca-se são os de fontes naturais e considerados de menor toxidade, como: SNS (óleo de mamona) que conseguem bom desempenho, mas são mais caros que os ftalatos tradicionais; óleo de soja acetilado, que converte grupos epóxi em óleo epoxidado, e também pode ser extraído, pelo ácido levulínico, da biomassa de celulose (GODWIN, 2011).

Além dos plastificantes, outros bioaditivos são usados na formulação do PVC, como: agentes biocidas, corantes, lubrificantes, cargas em fibras vegetais e minerais. Isso se tornou uma tendência de aplicação dos polímeros termoplásticos, especialmente o PVC (DE PAOLI; WALDMAN, 2019; TOLINSKI, 2017).

Nesta pesquisa, a formulação de PVC para solado foi escolhida, junto ao fornecedor, a partir de dois tipos de plastificantes oferecidos, um sintético, o primário e, outro, feito em óleo epoxidado, o secundário.

\subsubsection{Compósitos para solados}

Compósitos em calçados são, normalmente, utilizados para adição de propriedades mecânicas em segmento ortopédico. O calçado ortopédico tem a função de auxiliar na correção e no realinhamento da forma do pé (CORTE-RODRIGUEZ; RODRIGUEZ-MERCHAN, 2015; YICK, 2013). Além disso, verifica-se que há outras vertentes de pesquisas em compósitos para solados, que têm como foco principal a questão do impacto ambiental, com possibilidades de reciclagem de materiais, já consumidos, ou na substituição de parte dos materiais virgens, foco da presente pesquisa.

A utilização de carga de fibras celulósicas em compósitos tem a vantagem devido à abundância de material, baixo custo e por adicionarem propriedades de dureza e resistência (BENSADOUN et al., 2017); porém, há várias dificuldades na aderência fibra-polímero e na variação das propriedades mecânicas, que vêm sendo estudadas para a melhoria delas. 
Estudos indicam baixa aderência interfacial entre fibra-polímero, devido à baixa polaridade e afinidade química, entre a matriz e a fibra vegetal, e provoca falhas mecânico dos compósitos (PICKERING; EFENDY; LE, 2016). Agentes compatibilizantes podem melhorar a capacidade de aderência (mais comum os aditivos químicos acetil, silano e anidro maleico) em ligações químicas covalentes secundárias do tipo ácido-base ou pontes de hidrogênio (FARUK et al., 2014). A limpeza da fibra, na extração de ceras oleofínicas (FORTEAVERDEJO et al., 2017), também contribui para a aderência. O tratamento mais comum é com $\mathrm{NaOH}$, mas pesquisas apontam alternativas em uso enzimas (FARUK et al., 2014), adição de ureia.

As pesquisas sobre compósitos para calçados (Quadro 12) tem sido feitas utilizando cargas recicladas, principalmente, divididas em: resíduos reciclados da cadeia do calçado em couro, laminado sintético e EVA; ou resíduos vegetais misturados com polímeros, como fibra de banana, bagaço de cana, fruto do carvalho, entre outros (Figura 70).

Quadro 12 - Compósitos em polímeros para aplicação em solados (ordem crescente)

\begin{tabular}{|c|c|c|c|c|}
\hline Polímero & Tipo Carga & $\begin{array}{l}\text { Carga } \\
\operatorname{pcr}(*)\end{array}$ & Resultado & Referência \\
\hline SBR & $\begin{array}{l}\text { fruto do } \\
\text { carvalho }\end{array}$ & 2 & $\begin{array}{l}\text { Melhor comportamento } \\
\text { térmico, comparado com a } \\
\text { borracha pura }\end{array}$ & (KARAVANA et al., 2017) \\
\hline PVC & $\begin{array}{l}\text { laminado } \\
\text { sintético }\end{array}$ & 5 & $\begin{array}{l}\text { Perda de propriedades., uso } \\
\text { em alguns tipos de calçados }\end{array}$ & (DREGER et al., 2018) \\
\hline EVA & $\begin{array}{l}\text { fibra de } \\
\text { banana }\end{array}$ & 10 & $\begin{array}{c}\text { Melhora resistência ao } \\
\text { rasgo }\end{array}$ & (ZIMMERMANN et al., 2014) \\
\hline Resina epóxi & bucha vegetal & 10 & $\begin{array}{c}\text { Eficiência em } \\
\text { amortecimento em } \\
\text { entressola (até 80kg) }\end{array}$ & (AKANO; SUBERU, 2019) \\
\hline NR, SBR, SR & $\begin{array}{l}\text { EVA } \\
\text { reciclado }\end{array}$ & $10-20$ & $\begin{array}{l}\text { Inerte nas propriedades, } \\
\text { redução de custo }\end{array}$ & (LOPES et al., 2015) \\
\hline PU & $\begin{array}{l}\text { juta e } \\
\text { borracha }\end{array}$ & $10-30$ & $\begin{array}{l}\text { Inibir radiação de UV, } \\
\text { houve pouca influência }\end{array}$ & $\begin{array}{c}\text { (PARLAR; ABDLHAMED; } \\
\text { AKKURT, 2018) }\end{array}$ \\
\hline NR & couro & 40 & $\begin{array}{l}\text { Aumento resistência à } \\
\text { abrasão e tensão }\end{array}$ & $\begin{array}{l}\text { (FERREIRA; FREITAS; } \\
\text { ALMEIDA, 2010) }\end{array}$ \\
\hline NBR & $\begin{array}{l}\text { bagaço de } \\
\quad \text { cana }\end{array}$ & 40 & $\begin{array}{l}\text { Perda de propriedades., uso } \\
\text { em alguns tipos de calçados }\end{array}$ & (PAIVA et al., 2018) \\
\hline
\end{tabular}


Figura 70 - Compósitos de polímero e fibra vegetal aplicados em produtos no mercado calçadista - (a) Chinelo em NR e bagaço de cana, (b) Amostras composto injetado fibra-PVC da empresa PVC Sul

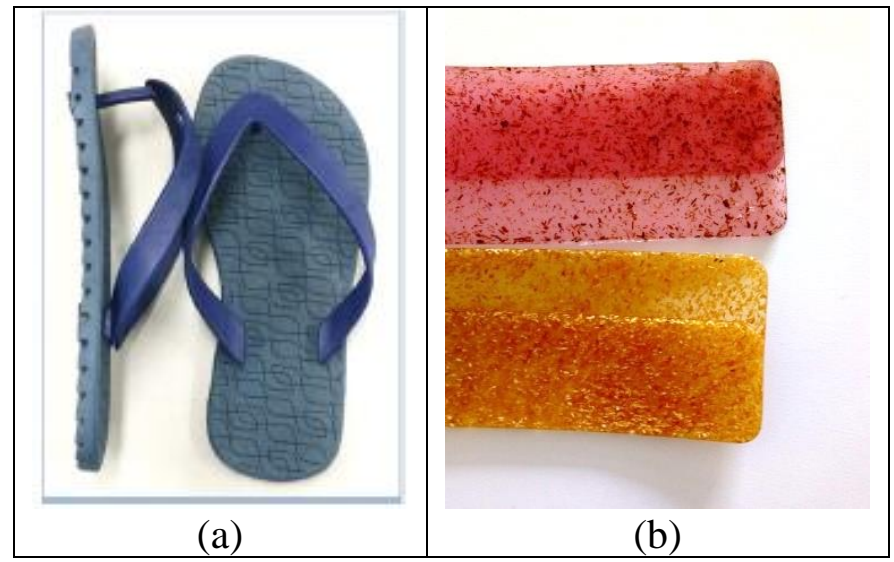

Fonte: (a) (PAIVA et al., 2018) (b) (Lais Kohan, 2020)

Algumas pesquisas (Quadro 12) tiveram resultados em aquisição de melhoria das propriedades mecânicas, quando inseridas fibras vegetais nos polímeros para solado, como ocorreu na pesquisa que utiliza NR e couro, houve o aumento da resistência à abrasão e tensão (FERREIRA; FREITAS; ALMEIDA, 2010); Borracha Estireno Butadieno (SBR) e resíduo do fruto da árvore carvalho, verificou-se o compósito comportamento resistiu a maiores temperaturas, ao se verificar a degradação térmica, em relação à borracha pura (KARAVANA et al., 2017); e a resina epóxi com a bucha vegetal, que resultou em boas propriedades de amortecimento (absorção de energia), suportando uma pessoa de até 80kg (AKANO; SUBERU, 2019). Enquanto, em outras pesquisas apresentaram baixa eficiência da carga, em que ela foi inerte ou reduziu as propriedades, em relação ao polímero virgem.

A aplicação em compósitos com matriz em PVC, foco deste trabalho, foi pesquisado com a carga em laminados sintéticos (tecido em poliéster com uma camada fina de PVC) e, como resultado, decaíram no valor das propriedades mecânicas (Quadro 12). Mesmo assim, optou-se por fazer esse compósito, por uma empresa brasileira (PVC Sul) ter lançado em 2019 um material semelhante com diversas fibras vegetais (cana, bambu, cortiça) (Figura 70b) e haver uma patente (European Patent Office - CN107312274) de uma fórmula de sola de PVC antibacteriana, usando 14\% de fibra de bambu e extrato de canela (MUZHONG; YUSHAN, 2017). 
6.3.3. Caracterização da serragem de bambu

\subsubsection{FTIR}

Resultados do teste FTIR são apresentados abaixo, através da técnica em espectroscopia na região do infravermelho médio, em que a Figura 71 apresenta o espectro da serragem de bambu (Dendrocalamus giganteus) utilizada no experimental do presente estudo e a Figura 72, a comparação de outras fibras vegetais, com curvas semelhantes. No espectro da serragem de bambu (Figura 72) é mostrado a comparação, entre o período de $2500-500 \mathrm{~cm}^{-1}$, sendo possível verificar semelhanças na curva do bambu (em vermelho) com o espectro da fibra externa da banana (rosa) e da fibra interna da banana (azul). Provavelmente, tal semelhança tem relação ao tipo da origem da fibra, pois as três são originárias do caule, de fibras vegetais, indicando essa similaridade das características químicas.

Figura 71 - Espectro do FTIR da serragem in natura de bambu (Dendrocalamus giganteus) empregada no presente estudo.

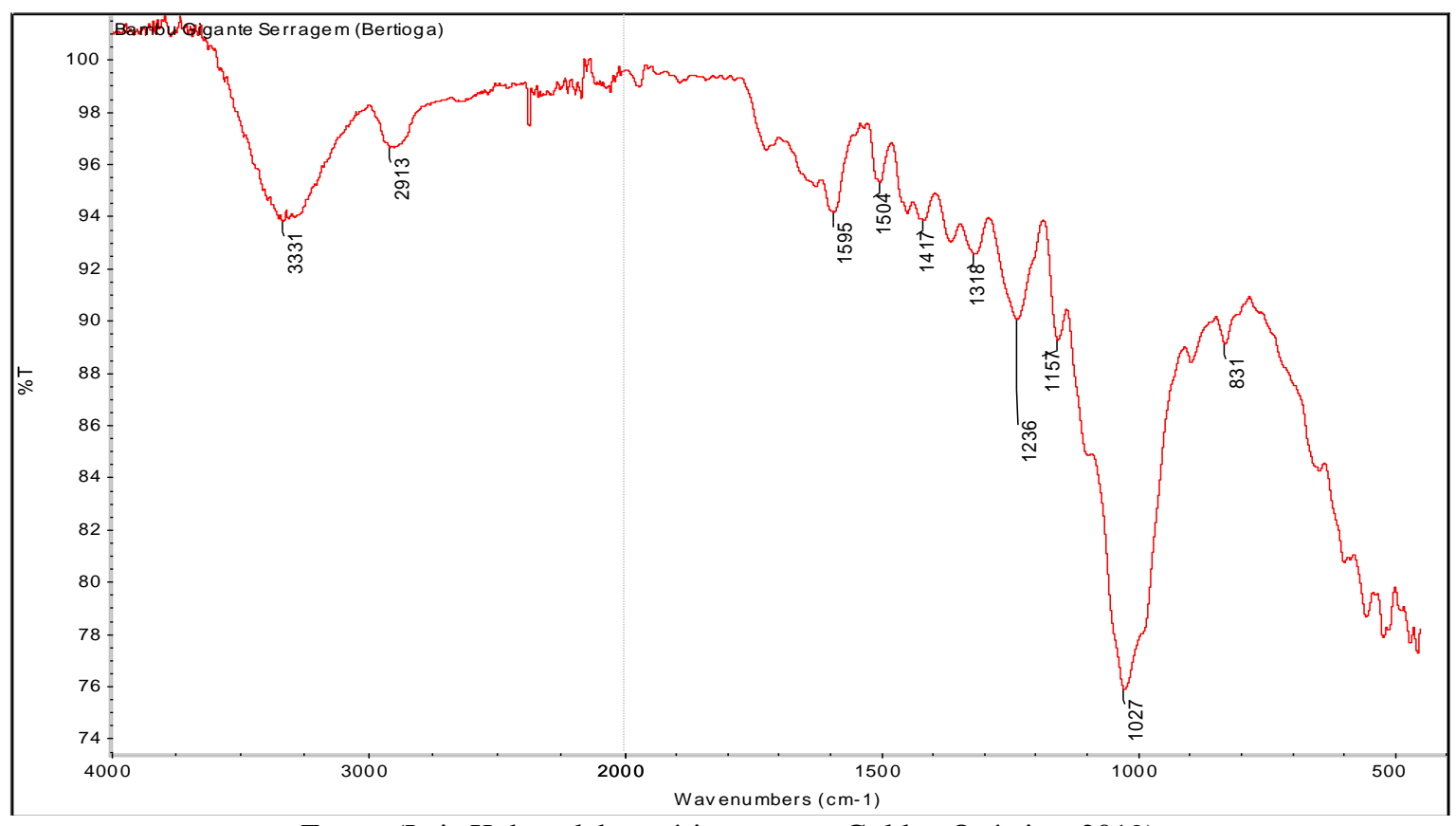

Fonte: (Lais Kohan, laboratório empresa Golden Química, 2019) 
Figura 72 - Espectros FTIR comparados: serragem de bambu gigante (vermelho), sisal (verde), curauá (lilás), juta (azul), banana prata fibra externa do pseudocaule (rosa) e banana prata fibra interna do pseudocaule (azul).

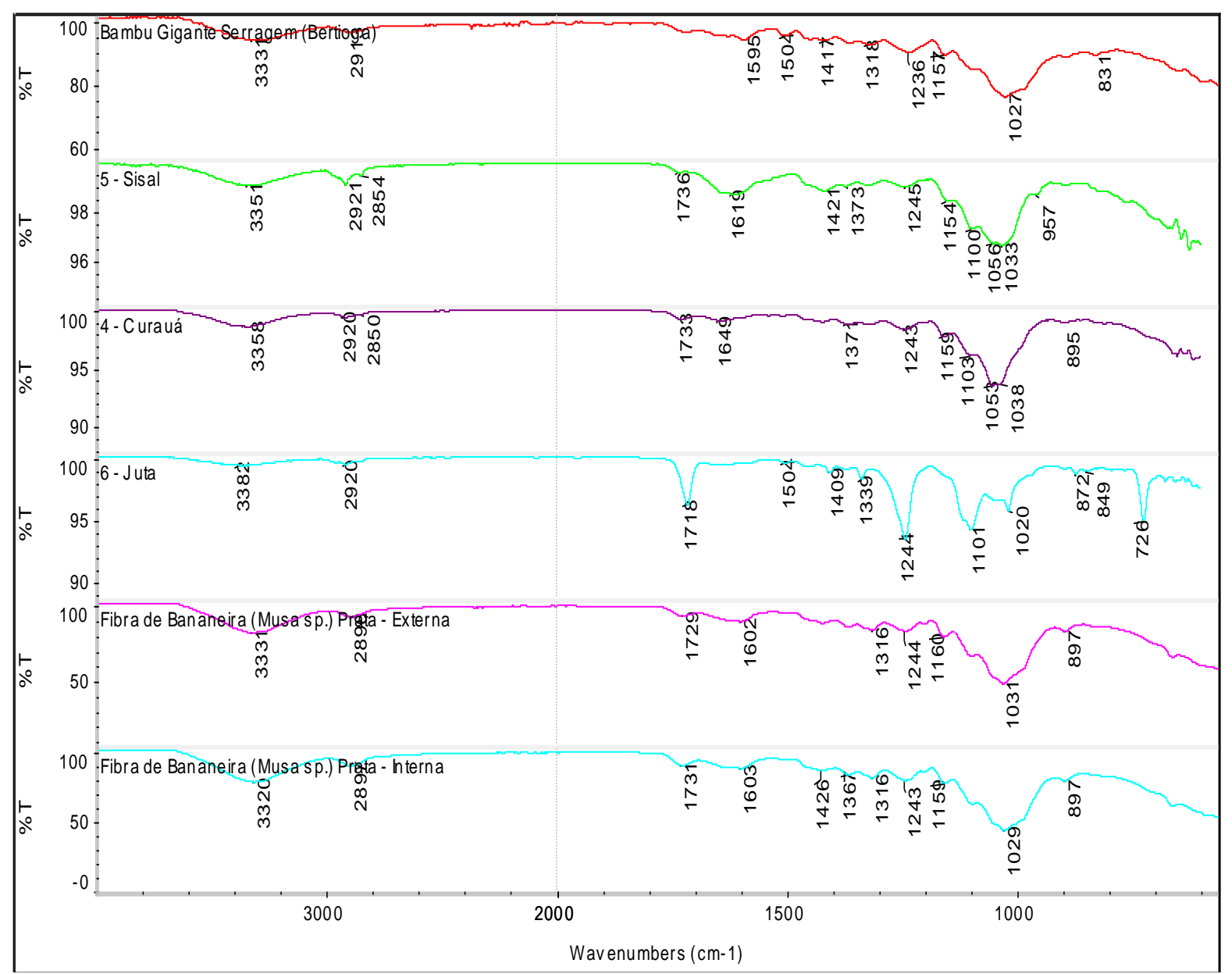

Fonte: (Lais Kohan, laboratório empresa Golden Química, 2019)

Para se analisar a composição das curvas geradas na Figuras 71 e 72, é necessário atribuir, a cada deformação angular, aos grupos de ligações químicas. As duas primeiras deformações dos gráficos são relacionadas às características dos materiais de origem vegetal e, por isso, já eram esperadas. Elas fazem parte faixa de bandas: a primeira, entre $3700-3200 \mathrm{~cm}^{-}$ ${ }^{1}$, é detectado a presença de grupo hidroxila; e a segunda, a faixa entre $3200-2800 \mathrm{~cm}^{-1}$, faz parte das bandas de estiramento C-H de grupos metilo $\left(2870 \mathrm{~cm}^{-1}\right.$ - estiramento assimétrico e $2960 \mathrm{~cm}^{-1}$ para simétrico) e metileno $\left(2930 \mathrm{~cm}^{-1}\right.$ assimétrico e $2850 \mathrm{~cm}^{-1}$ simétrico) (STUART, 2004). A partir dessas informações foi desenvolvida a Tabela 16, novamente comparando a serragem de bambu, a fibra do pseudocaule da banana prata (interna e externa), curauá, juta e sisal, escolha devida às maiores semelhanças nas características das curvas (Figura 72). 
Tabela 16 - Bandas de infravermelho determinadas para material fibroso de bambu (Dendrocalamus giganteus), banana fibra interna (Musa spp - cultivar prata), banana fibra externa (Musa spp - cultivar prata). e curauá (Ananas erectifolium), juta (Corchorus capsularis) e sisal (Agave sisalana).

\begin{tabular}{|c|c|c|c|c|c|c|}
\hline \multicolumn{6}{|c|}{ Número de onda $\left(\mathrm{cm}^{-1}\right)$} & \multirow[t]{2}{*}{ Atribuição } \\
\hline Bambu & $\begin{array}{l}\text { Banana } \\
\text { interna }\end{array}$ & $\begin{array}{l}\text { Banana } \\
\text { externa }\end{array}$ & Curauá & Juta & Sisal & \\
\hline ------ & ------ & ------ & 3358 & 3382 & 3351 & 3700-3200 estiramento $\mathrm{OH}$ \\
\hline 3331 & 3320 & 3331 & ------ & ------ & ------ & $3700-3200$ estiramento $\mathrm{OH}$ \\
\hline 2913 & 2897 & 2896 & 2920 & 2920 & 2921 & 3700-3200 estiramento $\mathrm{OH}$ \\
\hline ------ & ----- & ------ & 2850 & ------ & 2854 & $\begin{array}{c}2850 \text { metileno simétrico estiramento } \\
\text { C-H }\end{array}$ \\
\hline----- & 1731 & 1729 & 1733 & 1718 & 1736 & $\begin{array}{l}\text { 1740-1720 aldeído alifático } \\
\text { estiramento } \mathrm{C}=\mathrm{O}\end{array}$ \\
\hline 1595 & 1603 & 1602 & 1649 & ------ & 1619 & $\begin{array}{l}\text { 1680-1660 amida primária estiramento } \\
\qquad \mathrm{C}=\mathrm{O}\end{array}$ \\
\hline 1504 & ----- & ------ & ------ & 1504 & ----- & ------ \\
\hline 1417 & 1426 & ------ & ------ & 1404 & 1421 & ------ \\
\hline ----- & 1367 & ------ & 1371 & 1339 & 1373 & ------ \\
\hline 1318 & 1316 & 1316 & ------ & ------ & ------ & ------ \\
\hline 1236 & 1243 & 1244 & 1243 & 1244 & 1245 & 1240 estiramento C-O \\
\hline 1157 & 1159 & 1160 & 1159 & 1101 & 1154 & 1300-1100 estiramento C-O \\
\hline ----- & ------ & ------ & 1103 & ------ & ------ & 1100 estiramento C-O-C \\
\hline ------ & ------ & ------ & 1053 & ------ & 1056 & ------ \\
\hline 1027 & 1029 & 1031 & ------ & 1020 & 1033 & ------ \\
\hline ------ & ------ & ------ & ------ & 957 & ------ & \\
\hline ----- & 897 & 897 & 895 & 872 & & 1000-600 flexão fora do plano = C-H \\
\hline 831 & ------ & ------ & & 849 & & 1000-600 flexão fora do plano = C-H \\
\hline & & & & 726 & & \\
\hline
\end{tabular}

Fonte: Adaptado de (STUART, 2004)

No conceito sobre a função dos grupos das ligações químicas, o grupo hidroxila é responsável por fazer ligações intramoleculares (dentro da mesma cadeia) e intermoleculares (em cadeias adjacentes), sendo que ambas as fibras, bambu e as de banana possuem a mesma faixa da banda hidroxila $\left(3320-3331 \mathrm{~cm}^{-1}\right)$ (Tabela 16). O estiramento da ligação C-H nas três fibras (bananas e bambu) ficaram próximo da banda $2930 \mathrm{~cm}^{-1}$ - metileno assimétrico (MONTEIRO, 2016; STUART, 2004).

Observa-se pelos resultados apresentados na Figura 72 e Tabela 16 que os picos do espectro para a serragem de bambu apresentam mais semelhanças, do que diferenças com relação aos espectros das demais fibras analisadas. Ainda que, algumas dessas fibras sejam de 
folha (bananeira, curauá e sisal) e somente uma de caule (juta), essas semelhanças podem estar associadas ao fato de todas terem composição lignocelulósica.

Outras faixas de deformações importantes, comuns para fibras vegetais, não são possíveis diferenciar, entre os picos e dados, nas figuras anteriores, pois fazem parte da faixa de espectro de cerca de $1000 \mathrm{~cm}^{-1}$, que é relacionado à presença da celulose (GUIMARÃES, 2014; STUART, 2004). Na Tabela 17 são apresentadas as faixas de ondas dos principais compostos dos materiais vegetais.

Tabela 17 - Principais bandas de infravermelho médio encontradas em materiais vegetais

\begin{tabular}{cc}
\hline \multicolumn{1}{c}{ Tipo } & Número de onda $(\mathbf{c m}-\mathbf{1})$ \\
\hline$\alpha$-D-glucose & 915,840 \\
$\beta$-D-glucose & 915,900 \\
$\beta$-D-frutose & 873,869 \\
$\beta$-D-celulose & 916,908 \\
Celulose & $1170-1150,1050,1030$ \\
Lignina & 1590,1510 \\
Hemicelulose & 1732,1240 \\
Pectina & $1680-1600,1260,955$ \\
\hline Fonte: (GUIMARÃES, 2014; STUART, 2004)
\end{tabular}

\subsubsection{DSC}

O ensaio de DSC analisa os momentos de fluxo de calor do material, em contato com a temperatura (THOMAS; SCHMIDT, 2017). O resultado obtido desse teste é apresentado na Figura 73, em que a curva da DSC está em verde. 
Figura 73 - Resultado do ensaio de DSC e TGA, com serragem de bambu (Dendrocalamus giganteus) em Hitachi STA7200 - amostra $6,71 \mathrm{mg}$, temperatura entre $0-600^{\circ} \mathrm{C}$, em taxa de aquecimento de $10^{\circ} \mathrm{C} / \mathrm{min}$

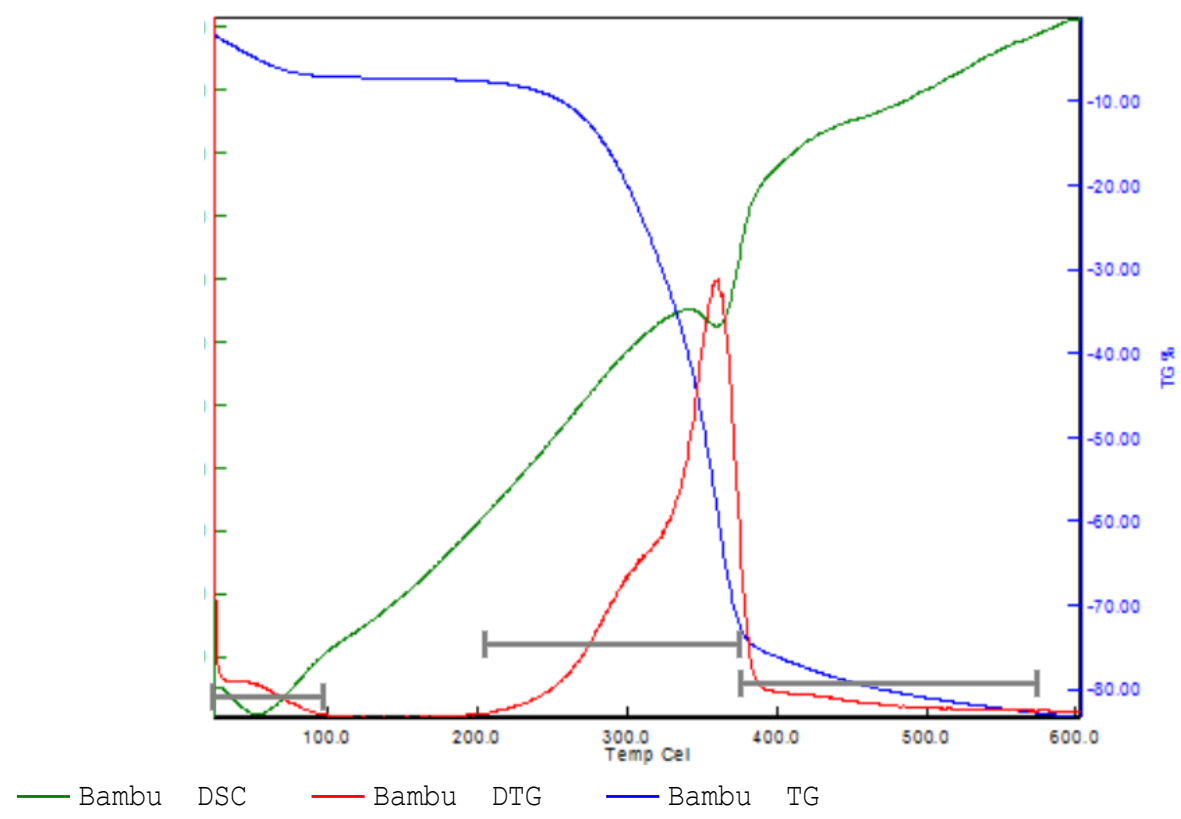

Fonte: (Lais Kohan, laboratório C2T2, Univ. do Minho, Portugal, 2019)

Importante salientar que, nessa curva DSC da Figura 73, há dois eventos ou picos negativos, relativos às reações endotérmicas. $\mathrm{O}$ primeiro ocorre a cerca de $50^{\circ} \mathrm{C}$, em que a amostra absorve o calor, na fase de transição endotérmica da água residual, de líquido para gasoso, que autores apresentam que esse pico endotérmico ocorre normalmente entre $50-100^{\circ} \mathrm{C}$ (MORGADO, 2009). O segundo pico ocorre entre as temperaturas de $340-380^{\circ} \mathrm{C}$, outro evento endotérmico, que já seria atribuído à degradação dos constituintes residuais das fibras. Como salientado anteriormente, na metodologia, nessa faixa de temperatura há a degradação da celulose, entre $300-350{ }^{\circ} \mathrm{C}$, e da lignina, após $370^{\circ}-580{ }^{\circ} \mathrm{C}$ (THOMAS; SCHMIDT, 2017).

\subsubsection{TGA}

O teste de TGA da serragem bambu foi feito no mesmo equipamento do DSC, como descrito anteriormente. A curva resultante do TGA (ou TG) é mostrada na Figura 73, em cor azul. Também compõe o gráfico a curva da DTG, que é a derivada e apresenta os eventos ou picos, que podem ser associados aos processos relacionados aos compostos constituintes do material analisado (THOMAS; SCHMIDT, 2017). 
Nos picos resultantes de TG (Figura 73), foram marcados os intervalos de temperatura próximo na parte mais baixa da figura, sendo que esses intervalos coincidem também com os eventos denotados na curva de DTG. O primeiro evento é referente à evaporação da água a $100^{\circ} \mathrm{C}$; o segundo, ocorre entre as temperaturas $200-370^{\circ} \mathrm{C}$, relativo à degradação da holocelulose (hemicelulose e celulose); e o terceiro, ocorre entre as temperaturas $370-580^{\circ} \mathrm{C}$, influenciado pela degradação da lignina (PARIDA; DAS; DASH, 2012; PENNAS, 2019).

Os dados extraídos da análise dos gráficos corroboram a literatura, em que os constituintes das fibras vegetais se degradam em temperaturas pré-definidas. Uma estimativa de concentração de cada constituinte da fibra vegetal foi verificada e calculada a partir da amostra de serragem bambu (Tabela 18). Para desenvolvê-la, foi consultada a base de dados de alimentação do gráfico (Figura 73), identificando a perda de massa, correspondente em \%, a partir dos dados da curva da TGA ou TG - azul, em função da temperatura (PENNAS, 2019).

Tabela 18 - Estimativa de concentração (\%) de água, celulose total e lignina, de acordo com as curvas TGA e DTG na amostra analisada de bambu (Dendrocalamus giganteus) e da referência da literatura para a mesma espécie de bambu

\begin{tabular}{cccc}
\hline Constituinte & Temperatura $\left({ }^{\circ} \mathbf{C}\right)$ & $(\%)$ & $\begin{array}{c}\text { Dados de } \\
\text { Literatura* }\end{array}$ \\
\hline Água & Até 100 & 7,01 & --- \\
Holocelulose & $200-370$ & 68,77 & 64,92 \\
Lignina & $370-580$ & 13,95 & 16,68 \\
\hline
\end{tabular}

Fonte: (Lais Kohan, 2020); *Adaptado de (MARAFON; AMARAL; LEMOS, 2019)

Também se comparou as estimativas realizadas com dados de literatura, sobre a composição bambu (Dendrocalamus giganteus), resultando em valores próximos (Tabela 18).

\subsubsection{Caracterização morfológica do compósito}

A partir da análise das imagens realizadas em MEV (Microscópio Eletrônico de Varredura), observa-se que, em todas amostras apresentadas na Figura 74 e no APÊNDICE H, houve boa dispersão da fibra da serragem de bambu no compósito, porém, não houve adesão entre polímero-fibra, fato esse, evidenciado pelos espaços vazios existentes em volta da fibra. 
Figura 74 - Imagens MEV do compósito PVC/bambu - 1 (1,5\% de serragem de bambu pura, sem tratamento - 200x e 1000x), M1 (1,5\% de serragem de bambu merceirizada - 170x e $850 x)$ e $S 1$ (1,5\% de serragem de bambu com tratamento em silano- 180x e 750x)

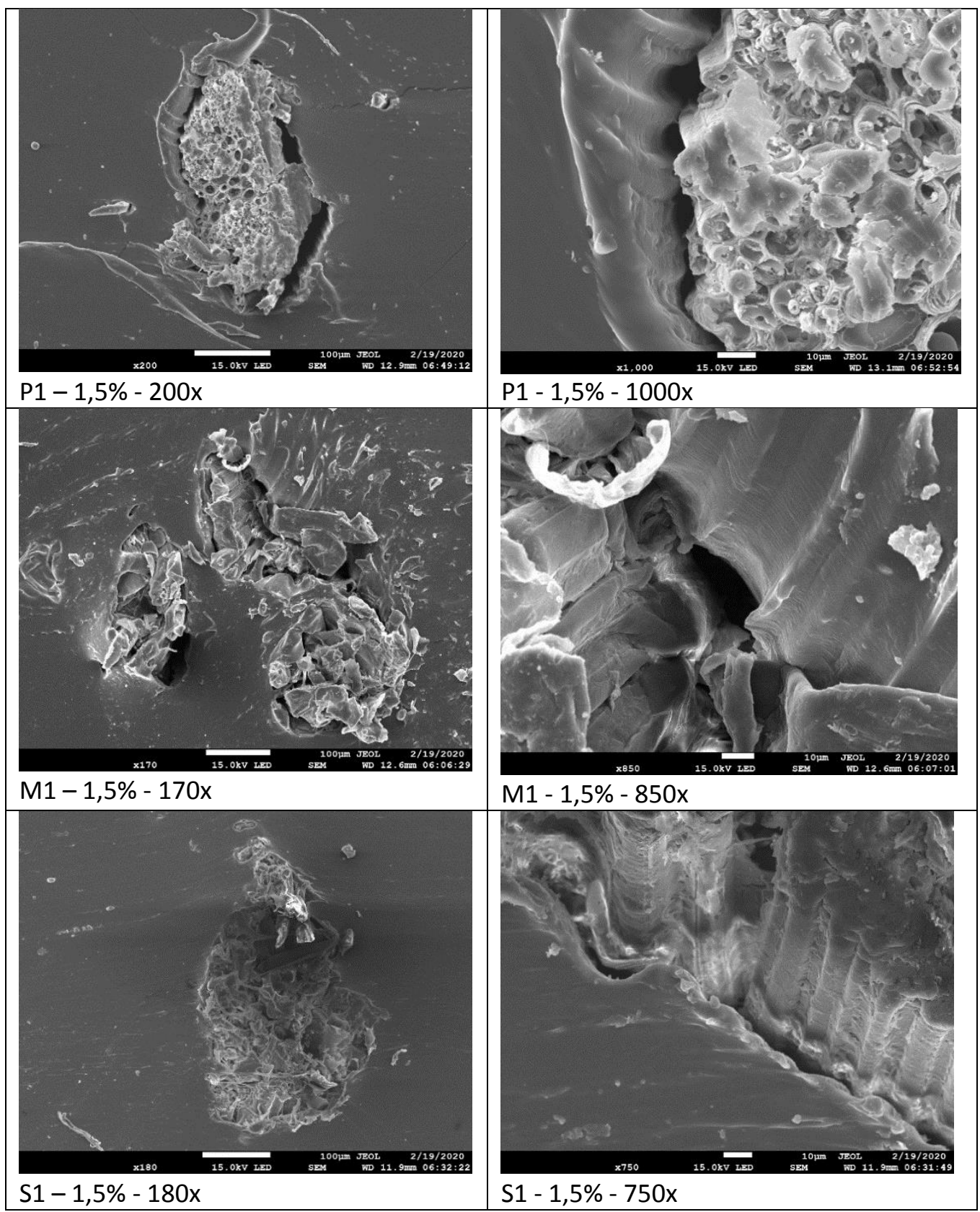

Fonte: (Lais Kohan, 2020)

Apesar de terem sido feitos dois tipos de tratamentos, por mercerização e silano, mesmo assim, não houve melhoria na adesão entre polímero-fibra da serragem (Figura 74). Deste modo, conclui-se que não houve diferenças significativas nesse quesito entre os compósitos de fibras não tratadas, em relação aos compósitos empregando fibras com algum tipo de tratamento. Entretanto, na amostra com 1,5\% de fibra de serragem de bambu tratada com silano 
são apresentados espaços menores, do que os observados para as fibras sem tratamento e fibras mercerizadas. Uma das hipóteses possíveis é a de que a questão da baixa afinidade (polaridade química) entre matriz e fibra não foi superada.

\subsubsection{Caracterização mecânica do compósito}

Os resultados para as caracterizações mecânicas são mostradas na Figura 75, elaborados a partir dos dados que estão no Apêndice I, para as amostras de PVC puro e PVC com serragem de bambu puro, com tratamento de $\mathrm{NaOH}$ e com tratamento de silano, em concentrações $(1,5 \% ; 3,0 \%$ e 6,0\%), em termos de Resistência à Tração na Carga Máxima (MPa), Resultado no Alongamento na Quebra (\%),Carga Máxima (N) e Módulo de Young (MPa).

Figura 75 - Resultado da Caracterização mecânica, nas amostras de PVC puro e compósitos de PVC com serragem de bambu puro, com tratamento de $\mathrm{NaOH}$ e tratamento de silano em concentrações $(1,5 \% ; 3,0 \%$ e 6,0\%) (a) Resistência à Tração na Carga Máxima (MPa), (b) Resultado no Alongamento na Quebra (\%), (c) Carga Máxima (N) e (d) Módulo de Young (MPa)

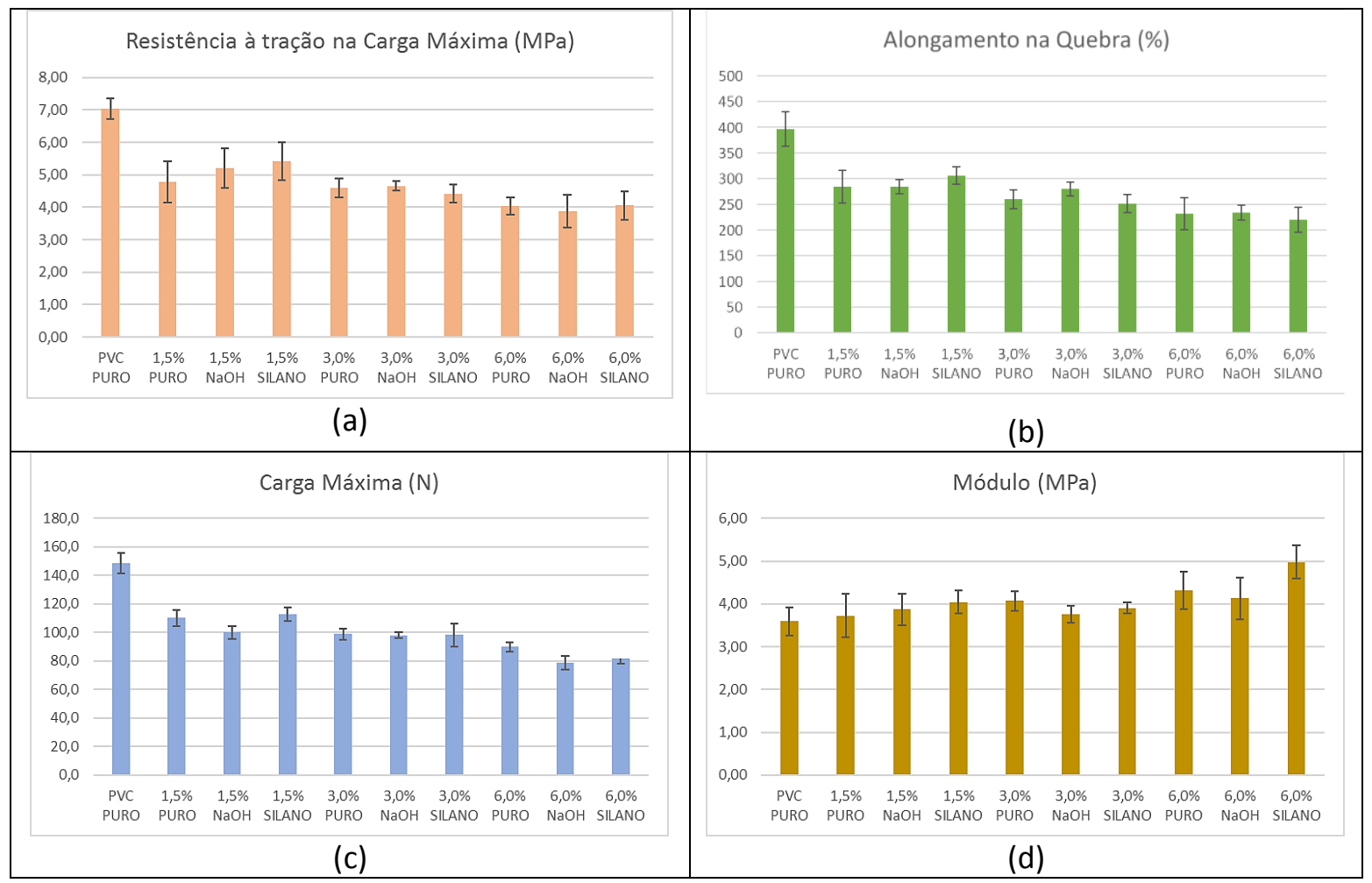

Fonte: (a) (b) (c) (d) (Lais Kohan, laboratório Física Têxtil - EACH, USP, 2020) 
A Figura 75 mostra que para os compósitos desenvolvidos, em PVC e fibra de serragem bambu, apresentaram valores inferiores, nos critérios de resistência à tração, alongamento e carga máxima, quando comparados ao PVC puro. Isso pode ser confirmado pela comparação das médias com as barras de erro (expressas como mais ou menos o desvio padrão).

Excluindo os valores para o PVC puro, na comparação entre as amostras de compósitos, aquela que obteve melhor resultado e apresentou valores ligeiramente maiores foi a que empregou o PVC e fibra (1,5\%), com tratamento de silano. Isso pode ser observado em todos os três critérios analisados (resistência à tração, alongamento e carga máxima), em que o tratamento de silano na fibra, em concentração de 1,5\%, foi a melhor opção (Figura 75). Os resultados também mostram tendências semelhantes sobre o desempenho, sendo que para todos os critérios, os três melhores resultados ocorreram quando se empregou a quantidade de fibras de 1,5\% (silano), modificando apenas a ordem de importância entre essas três amostras. Na análise do módulo de Young (Figura 75), houve o aumento dos valores com o aumento da quantidade de fibras.

De acordo com a literatura, na qual, ao invés do PVC, se utilizou NBR, foi apresentada uma indicação das propriedades mecânicas mínimas para se produzir um solado, de acordo com Germany - Prüf- und Forschungsinstitut (https://www.pfi-germany.de/en/about-pfi/pfi/) (DE PAIVA et al., 2019). Nela, atribui-se uma dureza Shore A mínima de 55, perda de abrasão máxima de $400 \mathrm{~mm}^{3}$, resistência à tração mínima em $5 \mathrm{MPa}$ e alongamento mínimo de $200 \%$. Pelos dados obtidos nesta pesquisa, o compósito contendo $1,5 \%$ de serragem de bambu, em tratamento com silano, se enquadraria em resistência à tração e alongamento, porém seria necessário repetir esses testes, uma vez, que se trata de materiais diferentes.

\subsubsection{Análise estatística dos resultados}

Para a verificação da influência da variável material na carga máxima de ruptura dos compósitos, os valores de carga máxima de ruptura (Figura 75 e Apêndice I) foram agrupados por tipo de material (PVC Puro, 1,5\% puro, 1,5\% $\mathrm{NaOH}, 1,5 \%$ Silano, 3\% puro, $3 \% \mathrm{NaOH}$, $3 \%$ Silano, $6 \%$ puro, $6 \% \mathrm{NaOH}, 6 \%$ Silano) e desta forma, estabelecidas as hipóteses para o teste.

As hipóteses testadas são a hipótese nula, $\mathrm{H}_{0}$ para qual todas as médias são iguais e para a hipótese alternativa, $\mathrm{H}_{1}$ de que pelo menos uma média é diferente. $\mathrm{O}$ nível de significância 
para tomada de decisão é $\alpha=0,05$ ou seja, para aceitar a hipótese nula é necessário um valor de $\mathrm{p}$ (p-value) maior que 0,05 .

6.3.6.1. Influência do material compósito na carga máxima

Os resultados estatísticos obtidos foram feitos com o auxílio da doutoranda Márcia Cristina Silva (UFABC).

Resultados da análise ANOVA estão descritos na Tabela 19:

Tabela 19 - ANOVA diferentes materiais e em diferentes níveis para carga máxima de ruptura

\begin{tabular}{c|ccccc}
\hline \multicolumn{7}{c}{ ANÁLISE DE VARIÂNCIA } \\
\hline FONTE & Graus de & Soma dos & Quadrado & Estatística F & P- \\
MATERIAL & Liberdade & Quadrados & Médio & & Value \\
ERRO & 9 & 21029 & 2336,54 & 89,83 & $\mathbf{0 , 0 0}$ \\
TOTAL & 50 & 1301 & 26,01 & & \\
\hline \multicolumn{7}{c}{ Fonte: Adaptado de (SILVA, 2018) }
\end{tabular}

O valor de $\mathrm{p}$ ( $\mathrm{p}$-value) menor que 0,05 demonstra que as amostras possuem médias para carga máxima de ruptura estatisticamente diferentes. A Figura 76 demonstra os valores de média para carga máxima de ruptura e o intervalo de confiança para o material utilizado no compósito. 
Figura 76 - Efeito das médias de velocidade de queima após ANOVA para diferentes materiais: (a) Gráfico de efeitos; (b) Carga máxima de ruptura com 95\% de intervalo de confiança

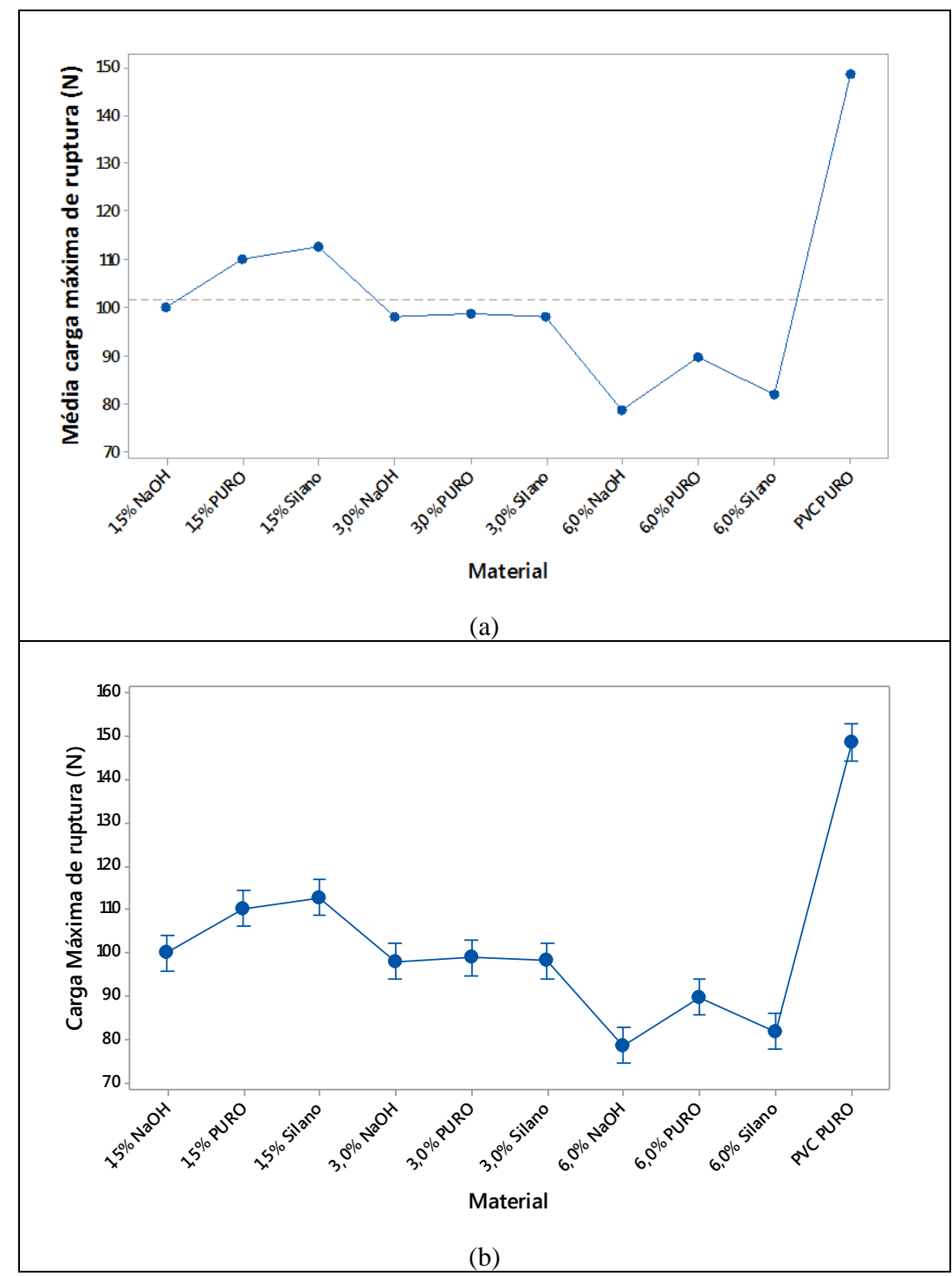

Fonte: (Lais Kohan, 2020)

$\mathrm{Na}$ Figura 76a, pode ser observado que a carga de ruptura média é maior para o material PVC Puro, corroborado com o valor de p (p-value) igual a 0,00 e a Figura 76b, mostrando a sobreposição dos intervalos de confiança dentro das quantidades de material aplicado, confirma que as médias de carga de ruptura são estatisticamente iguais em cada agrupamento.

Para validação da análise foi necessário a verificação dos resíduos, conforme ilustrado na Figura 77. 
Figura 77 - Resultados da análise dos resíduos após ANOVA carga máxima de ruptura $\mathrm{x}$ materiais: (a) Histograma dos resíduos; (b) Papel da probabilidade para os resíduos; (c) Resíduos x Valores ajustados; (d) Resíduos x Ordem de coleta.

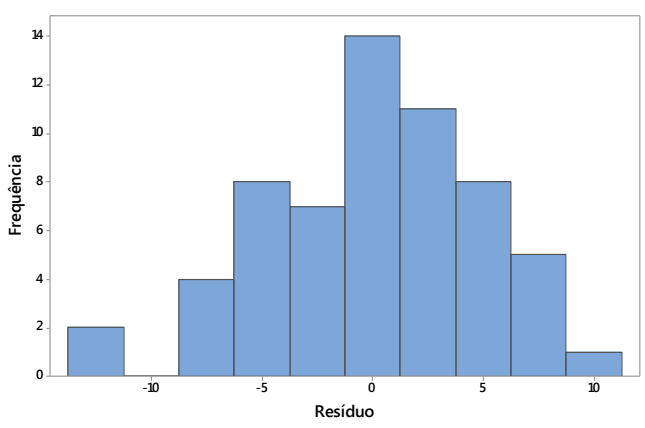

(a)

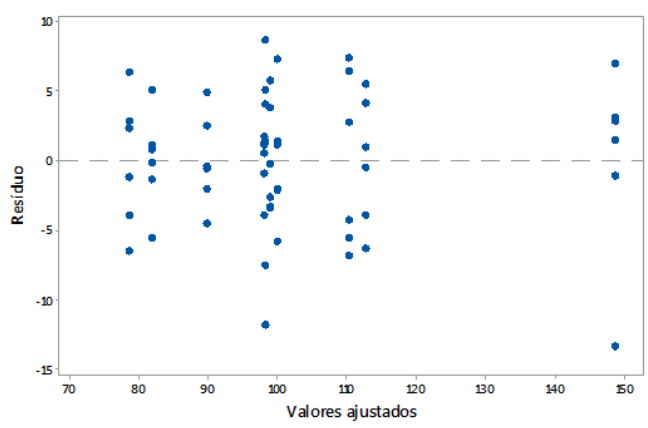

(c)

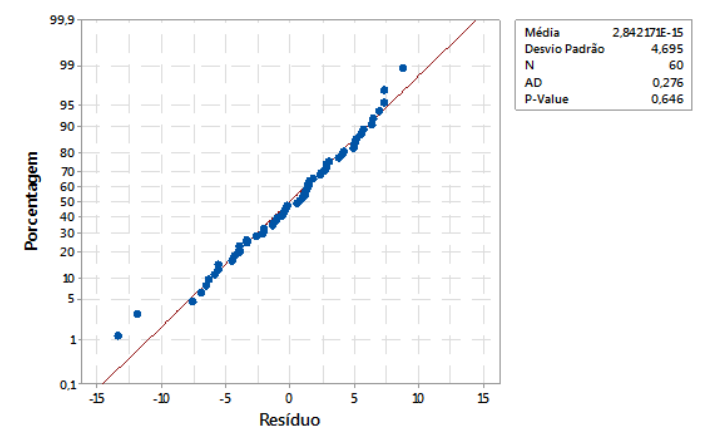

(b)

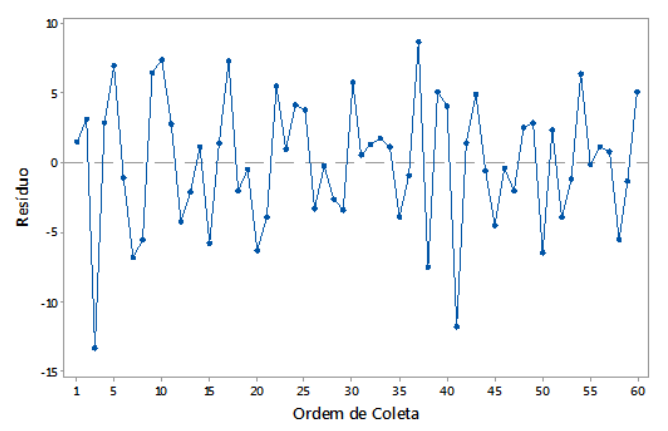

(d)

Fonte: Laís (2020)

O histograma dos resíduos (Figura 77a) demonstra a sua dispersão e distribuição e juntamente com o papel da probabilidade (Figura 77b) e teste de normalidade AndersonDarling com valor de $\mathrm{p}$ (p-value) igual a 0,646 confirmam que os dados apresentam distribuição normal.

Na Figura 77c, resíduos x valores ajustados demonstram graficamente que a variância dos resíduos apresenta igualdade. Também foi possível verificar a independência dos resíduos, pois a Figura 77d não apresenta comportamento sistemático, sem indício de influência externa ao experimento.

Para a confirmação de que os resíduos apresentem igualdade de variância, foram realizados os testes de Bartlet, resultando em valores de $p$ (p-value) igual a 0,2281. Também foi possível confirmar tal igualdade graficamente, conforme demonstrado na Figura 78. 
Figura 78 -Análise de Variância para carga máxima de ruptura $\mathrm{X}$ tipos de materiais

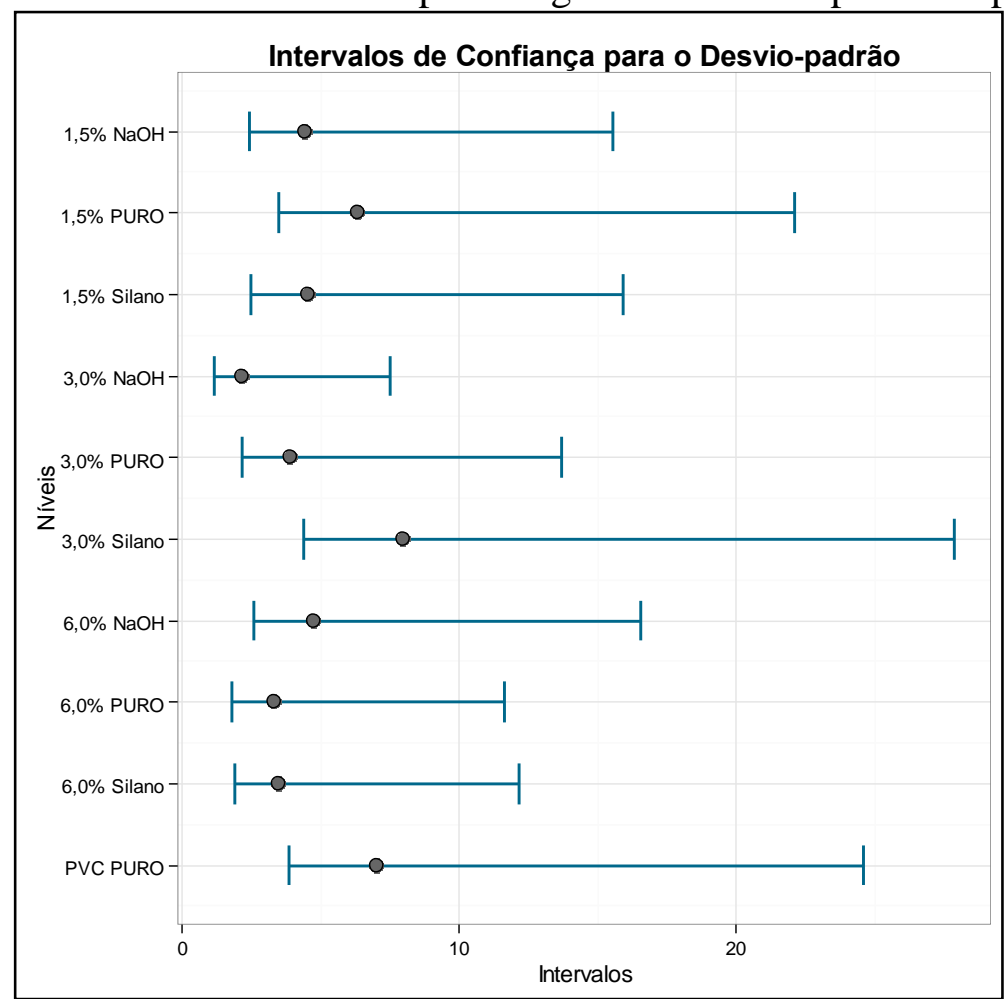

Fonte: Laís, 2020

$\mathrm{Na}$ Figura 78 é possível verificar a sobreposição dos intervalos de confiança, confirmando a igualdade de variância dos resíduos.

Atendidas a exigências de normalidade e igualdade de variância dos dados, a ANOVA é validada, rejeitando-se a hipótese nula, em face a um tratamento (PVC Puro) com a média diferente aos demais tratamentos. 


\section{CONSIDERAÇÕES FINAIS}

A importância do tema da sustentabilidade no setor de calçados vem crescendo no Brasil, principalmente, fomentado pelas associações Assintecal, Abicalçados e IBB, que promovem a feira Inspiramais, selo Origem Sustentável e diversos projetos, como Projeto Exportador; além de feiras internacionais e outros eventos. A feira Inspiramais, há alguns anos, vem desempenhando um papel de fomento à cadeia com esses projetos, aliando a sustentabilidade aplicada aos componentes, o que contribuiu no desenvolvimento desses materiais e ampliou a variedade deles, entre os fabricantes do setor.

Mesmo com essa iniciativa da feira Inspiramais, em incentivo sustentável no setor calçadista nacional, verifica-se que a maioria dos participantes ainda não incluíram em seu portifólio produtos desenvolvidos com matéria prima ou outras ações atribuídas à sustentabilidade, o que foi conferido nesta pesquisa, através da coleta de informações. Verificou-se que há 116 empresas (64\% do total de participantes do Inspiramais), que ainda não adotaram essas práticas, enquanto 90 empresas possuem alguma iniciativa. $\mathrm{O}$ critério de materiais sustentáveis foi o mais recorrente (37 empresas), dentre as práticas sustentáveis, mas foram segmentadas em outras ações no campo da sustentabilidade (classificadas por quantidade de empresas) e: reciclagem (27), processo (12), certificação (8), reuso (7) e social (4). Estes critérios foram todos considerados para classificar se elas têm ações ou não, de acordo com o que declaravam em suas páginas institucionais. Os critérios não eram muito rígidos, poderiam declarar apenas fazer uma ação social, por exemplo, já se enquadrariam no quesito sustentável.

Os resultados obtidos por meio das entrevistas confirmam essa variedade de ações, diante dos critérios apontados pela pesquisa, porém também foi evidenciado que, em geral, há ainda pouco foco nos produtos sustentáveis. Algumas companhias somente usaram fios reciclados (critério material) em seu processo, como foi apresentado nas entrevistas com empresas têxteis, Empresa B e D. As empresas A e E possuem um processo enxuto, isto é, não têm resíduos e nem efluentes (processo), mas, tais fatos nem sempre são evidenciados nas páginas institucionais, o que foi conferido sobre a Empresa A. Por sua vez, a empresa E e Cipatex, trabalha com PVC, cuja matéria prima já contém quase $60 \%$ de fontes naturais (sal marinho), para se adequarem à regulamentação internacional, na substituição de plastificantes nocivos aos humanos, utilizando a inserção do óleo vegetal epoxidado (critério material). Além do mais, o PVC em si é passível de reciclagem, mas não se tem conhecimento dessa prática no país. A Empresa $\mathrm{C}$, que tem o negócio já envolvido em prol da reciclagem, utiliza o resíduo de 
fabricantes de sapato e desenvolve o contraforte (critério material) e, ainda, mantém um preço competitivo.

O selo “Origem Sustentável” passou por uma reformulação em 2019, tornando-o mais rígido para a obtenção dos níveis da certificação, impedindo a aquisição dele, sem a devida comprovação (auditoria), o que antes, por consequência da falta estrutura para verificar as informações, ocasionou o uso por algumas empresas apenas como marketing, principalmente as que possuíam os níveis branco e bronze. Conforme descrição da entrevistada do IBB, estaria ocorrendo um esforço da cadeia na cooperação para mais empresas se certificarem, a partir do exemplo dado por ela, além do que está havendo uma exigência, por parte de alguns grandes fabricantes de calçados brasileiros, para que seus fornecedores sejam certificados também.

As informações declaradas pelo IBB das mudanças ocorridas, sobre a nova versão do selo, foram confirmadas pelas duas empresas entrevistas no nível ouro, uma já feita a recertificação (Empresa F) e outra, a Cipatex, em vias de aquisição, em que ambas mostraram as ações concretas na dimensão ambiental, em reduções de geração de resíduos, soluções em destinação e controle de substâncias restritas. Com base na literatura central da pesquisa, os dois primeiros processos corroboram com as ações reativas e o último, relacionado à proativa, na substituição de matérias primas (STAIKOS et al., 2006).

O experimento laboratorial de uma formulação para destinação à aplicação em solado não obteve resultados desejáveis, já que, ao invés da melhoria ou minimamente a manutenção, houve o decaimento das propriedades, incorporando-se fibras não tratadas e tratadas, verificado através dos resultados nos testes mecânicos e morfológico. Assim, os resultados demonstraram que a resistência à tração, o alongamento e o valor da carga máxima apresentaram redução em todas amostras, em diferentes porcentagens de fibras e tratamentos utilizados, quando comparados aos resultados do PVC puro. Isto de fato limita a possibilidade desses compósitos. Mesmo assim, há um produto semelhante no mercado (Figura 70b). Também há o apelo visual dos compósitos desenvolvidos pelas cores resultantes e o grau de transparência do material, quando utilizada a serragem (vide Figura 55, item 5.2.6.). Entre as amostras desenvolvidas, exceto o PVC puro, a que aparentemente apresentou melhor resultado foi o compósito PVC e $1,5 \%$ de serragem de bambu tratada com silano.

Com os resultados apresentados desta pesquisa, dada à atual conjuntura econômica do Brasil, afetada no ano de 2020 com a pandemia do coronavírus, apresenta-se diversos problemas a serem enfrentados, devido ao declínio industrial e, também, com a redução do 
poder aquisitivo das famílias com o aumento da taxa de desemprego; agravando a situação de crise, que já perdura há alguns anos (desde 2015). Sobre a cadeia calçadista brasileira, inserida nesse contexto recente, já apresenta estimativa de redução de 26-30\% da produção de pares (em 2020) e demissão de 35 mil trabalhadores do setor, apresentados, ainda, no mês de junho (ABICALÇADOS, 2020). Outros entraves setoriais envolverão em breve questões importantes, como o vencimento da taxação de importação do par do calçado chinês, em 2021.

O comércio internacional impõe documentações comprobatórias, que são os mecanismos necessários para realizar as exportações, como apresentado neste trabalho. Há grande exigência de testagem dos calçados e de componentes brasileiros para confirmar a ausência de matérias primas restringidas. Nesse contexto, há também as pressões internacionais e nacionais, em geral macroeconômicas, para preservação, como está ocorrendo na questão da Amazônia. Como essas ações não são mais isoladas, elas podem gerar penalizações, afetando os setores produtivos exportadores. Inclusive houve um fato, em 2019, que ameaçou as exportações do couro brasileiro, cuja reação foi motivada ao descaso do governo brasileiro diante o aumento das queimadas na Amazônia naquele ano, mas que ao fim, daquela vez, acabou não se concretizando (DUARTE, 2019). Outra pressão ambiental mundial vem ocorrendo, no mesmo tema, no caso dos curtumes, o que foi apontado pela literatura, em que o país, por ser exportador de couro bovino, precisou realizar um maior controle quanto à incineração do crômio (RAJAMANI, 2014).

A mudança ocorrida, em 2019, quanto ao aumento da exigência do selo "Origem Sustentável" é uma medida alinhada ao novo contexto mundial. Esta crise que está ocorrendo no país pode também ser encarada com a necessidade do setor se transformar, como declarado pela Empresa F, em que foram exigidos dos fornecedores a transparência e comprovação de uso de matérias primas, também conferido a mesma posição, no evento "Sustentabilidade: é hora de avançar". Além do mais, o poder aquisitivo do cidadão brasileiro decaiu, afetando ainda mais o consumo e a produção nacional de calçados, uma vez que ela é destinada, em sua maioria (cerca de 80\%), ao mercado consumidor nacional. Somado a isso, há a desvalorização do real, mas sem uma política adequada para abertura de caminhos à exportação para o setor calçadista.

Por fim, poucas ações ainda são refletidas em soluções concretas no Brasil, referentes à circularidade dos produtos e da necessidade de reestruturar o manejo dos resíduos sólidos, inclusive do calçado após o uso. A empresa Cipatex sugeriu em desenvolver um programa de reciclagem, com metas claras, como aconteceu na União Europeia (desde 2010), no setor de PVC. Por lá, ações concretas sobre metas já exigem a redução em 30\% de uso de materiais de 
origem do petróleo até 2030. Aqui no Brasil, a PNRS se tornou uma diretriz legal, em que já está atribuída a responsabilidade partilhada por todos, inclusive os corresponsáveis durante o ciclo de vida do produto, mas pouco foi feito, desde a sua criação.

Com base nestas considerações, a presente autora sugere para pesquisas futuras estudos sobre soluções em logística reversa, biopolímeros, reciclabilidade de calçados pós consumo, aumento qualidade e da durabilidade dos calçados, soluções de design para evitar desperdícios durante a produção. 


\section{CONCLUSÃO}

Os dados coletados sobre as empresas do Inspiramais apresentaram, quanto às ações sustentáveis: 56\% (90 empresas) não fazem nenhuma ação, 40\% (63 empresas) fazem pelo menos uma das seis categorias de ações (dentre: material - 37, reciclagem - 27, certificação 12, social - 8, processo -7 e reuso - 4). As categorias mais recorrentes foram material e reciclagem; em material apresentaram as seguintes ações: uso de polímeros em base vegetal, fio em fibra natural, matérias primas recicladas, isento de solvente aromático e metais pesados, base d'água, entre outros. Seguido de reciclagem em ações que incluem, principalmente, a reciclagem dos materiais e tratamento de água.

Os resultados obtidos por meio das entrevistas mostraram as ações sustentáveis feitas pelas empresas em: aplicação de matéria prima reciclada, em fios de poliéster (Empresa B e D), baixa emissão de resíduos e efluentes (Empresa A e E), ), negócios na reciclagem de tecidos e componente produzido com $50 \%$ de resíduos de tecidos e laminados vindos dos clientes (Empresa C).

Os benefícios adquiridos internamente pela dimensão ambiental, do selo "Origem Sustentável", foram descritos a partir de soluções semelhantes, tanto pelas empresas quanto pela associação, em que, por meio das entrevistas, declararam a redução dos resíduos gerados (25\% pela Empresa F), destino adequado aos resíduos do processo (coprocessamento Empresa $\mathrm{F}$ e venda para a reciclagem - Cipatex). As demandas voltadas à exportação, houve a necessidade de testagem e declaração de isenção das substâncias restritas e a certificação auxiliou para obter essas informações dos fornecedores (Empresa F); ou também, por ter engajado todos os funcionários das empresas, quanto à sustentabilidade, o que ajudou indiretamente na exportação dos laminados sintéticos para o mercado americano (Cipatex).

No experimento do compósito de PVC com serragem de bambu, todas as amostras, com ou sem tratamentos, apresentaram resultados inferiores ao PVC puro, o que restringe esse tipo de aplicação de fibras em solados. A amostra com 1,5\% de serragem de bambu, em tratamento com silano, apresentou uma aparente melhora, em relação aos outras amostras.

Por fim, constatou-se ao longo da pesquisa que mesmo a PNRS se tornando uma diretriz legal em 2010, apesar das iniciativas incipientes nas empresas e associações do setor calçadista, ainda há muito o que fazer para atingir a circularidade em termos de logística reversa e produção. 


\section{REFERÊNCIAS BIBLIOGRÁFICAS}

ABICALÇADOS. Nossa história. [s.d.]. Disponível em: https://www.abicalcados.com.br/quem-somos. Acesso em: 12 jun. 2020.

ABICALÇADOS. Relatório setorial indústria de calçados. 2016. Disponível em: http://abicalcados.com.br/publicacoes/relatorio-setorial. Acesso em: 10 abr. 2020.

ABICALÇADOS. Relatório setorial indústria de calçados - Brasil 2017. 2017. Disponível em: http://abicalcados.com.br/publicacoes/relatorio-setorial. Acesso em: 14 abr. 2020.

ABICALÇADOS. Relatório setorial indústria de calçados - Brasil 2018. 2018. Disponível em: http://abicalcados.com.br/publicacoes/relatorio-setorial. Acesso em: 15 jul. 2020.

ABICALÇADOS. Relatório Setorial da Indústria de Calçados - Brasil 2019. 2019. Disponível em: http://abicalcados.com.br/publicacoes/relatorio-setorial. Acesso em: 12 maio. 2020.

ABICALÇADOS. Indústria calçadista atinge a marca de $\mathbf{3 5}$ mil demissões durante a pandemia. 2020. Disponível em: https://www.abicalcados.com.br/noticia/industria-calcadistaatinge-a-marca-de-35-mil-demissoes-durante-a-pandemia. Acesso em: 17 ago. 2020.

ABINT. Classificação, identificação e aplicações de nãotecidos. [s.d.]. Disponível em: http://www.abint.org.br/pdf/Manual_ntecidos.pdf. Acesso em: 20 mar. 2019.

ACSP. Média Mensal da Cotação do Dólar Comercial para Venda. 2020. Disponível em: https://economia.acspservicos.com.br/indicadores_iegv/iegv_dolar.html. Acesso em: 10 ago. 2020.

ADIDAS. TÊNIS ASWEERUN. 2020. Disponível em: https://www.adidas.com.br/tenisasweerun/EE8444.html. Acesso em: 12 abr. 2020.

AKANO, T. T.; SUBERU, I. On Design and Analysis of Damping Physiognomies of Reinforced Composite Loofah Sponge on Athlete's Shoe. Journal of Science and Engineering, [S. l.], v. 16, n. 2, p. 32-45, 2019.

ALBERS, Kyle; CANEPA, Peter; MILLER, Jennifer. Analyzing the Environmental Impacts of Simple Shoes A Life Cycle Assessment of the Supply Chain and Evaluation of End-ofLife Management Options. 2008. University of Santa Barbara, California, [S. l.], 2008. Disponível em: https://www.bren.ucsb.edu/research/documents/SimpleShoesFinalReport.pdf.

ALBINANTE, S. R.; PACHECO, E. B. A. V.; VISCONTE, L. L. Y. Revisão dos tratamentos químicos da fibra natural para mistura com poliolefinas. Química Nova, [S. l.], v. 36, p. 114122, 2013. DOI: https://doi.org/10.1590/S0100-40422013000100021.

AMBIENTE VERDE. Ambiente Verde - Apresentação Institucional. 2019. Disponível em: https://d7ae7404-52ff-4157-9544-

63fc5059bd89.filesusr.com/ugd/813307_24d323732a1f4d73b26efab7d6a24f3d.pdf. Acesso em: 15 fev. 2020.

AMORIM, David Jose Nogueira; NACHTIGALL, Troy; ALONSO, Miguel Bruns. Exploring mechanical meta-material structures through personalised shoe sole design. In: PROCEEDINGS OF THE ACM SYMPOSIUM ON COMPUTATIONAL FABRICATION 2019, New York, NY, USA. Anais [...]. New York, NY, USA: ACM, 2019. p. 1-8. DOI: 10.1145/3328939.3329001. Disponível em: https://dl.acm.org/doi/10.1145/3328939.3329001. 
AMZA, Cătălin; ZAPCIU, Aurelian; POPESCU, Diana. 3D-Printed shoe last for bespoke shoe manufacturing. MATEC Web of Conferences, [S. l.], v. 290, p. 04001, 2019. DOI: 10.1051/matecconf/201929004001. Disponível em: https://www.matecconferences.org/10.1051/matecconf/201929004001.

ANDRADE, José Eduardo Pessoa De; CORRÊA, Abidack Raposo. Overview of the global footwear industry, with an emphasis on Latin America. BNDS Setorial, [S. l.], v. 3, p. 95-126, 2001. Disponível em: http://bibliotecadigital.ilce.edu.mx/sites/ciencia/volumen2/ciencia3/081/htm/oceano.htm.

AREZZO. Mule Croco Salto Rasteiro Rose Matte - Inverno 2020. 2020a. Disponível em: https://www.arezzo.com.br/shapes_inverno/mule-croco-salto-rasteiro-rosematte/p/1146300070007U. Acesso em: 12 abr. 2020.

AREZZO. Espadrille Laço Nobuck Plataforma Mus Yellow. 2020b. Disponível em: https://www.arezzo.com.br/sapatos/sandalias/espadrille-laco-nobuck-plataforma-musyellow/p/0460000860002U. Acesso em: 5 maio. 2020.

ASHTON, Elisa Guerra. Analysis of footwear development from the design perspective: Reduction in solid waste generation. Strategic Design Research Journal, [S. l.], v. 11, n. 1, p. 2-8, 2018. DOI: 10.4013/sdrj.2018.111.01. Disponível em: http://revistas.unisinos.br/index.php/sdrj/article/view/12656.

ASSINTECAL. Institucional. [s.d.]. Disponível em: https://www.assintecal.org.br/. Acesso em: 12 jun. 2020.

ASSINTECAL. Estudo de Quantificação de Materiais. 2018. Disponível em: https://www.assintecal.org.br/estudo-de-quantificacao-de-materiais. Acesso em: 20 jun. 2020.

ASSINTECAL. Evento aborda sustentabilidade na cadeia coureiro-calçadista. 2019. Disponível em: https://www.assintecal.org.br/noticias/1861/evento-aborda-sustentabilidadena-cadeia-coureiro-calcadista. Acesso em: 20 jul. 2020.

\section{ASTM INTERNATIONAL. ASTM D412 - Standard Test Methods for Vulcanized Rubber and Thermoplastic Elastomers Tension. Conshohocken, PA. DOI: https://doi.org/10.1520/D0412-16. Disponível em: https://compass.astm.org/EDIT/html_annot.cgi?D412+16\#s00001.}

AUAD, Priscila; SPIER, Franciela; GUTTERRES, Mariliz. Vegetable tannin composition and its association with the leather tanning effect. Chemical Engineering Communications, [S. l.], v. 207, n. 5, p. 722-732, 2020. DOI: 10.1080/00986445.2019.1618843.

BANERJEE, Amitav; CHITNIS, UB; JADHAV, SL; BHAWALKAR, JS; CHAUDHURY, S. Hypothesis testing, type I and type II errors. Industrial Psychiatry Journal, [S. l.], v. 18, n. 2, p. 127, 2009. DOI: 10.4103/0972-6748.62274. Disponível em: http://www.industrialpsychiatry.org/text.asp?2009/18/2/127/62274.

BARTLEY, TIM; EGELS-ZANDÉN, NIKLAS. Responsibility and neglect in global production networks: the uneven significance of codes of conduct in Indonesian factories. Global Networks, [S. l.], v. 15, n. s1, p. S21-S44, 2015. DOI: 10.1111/glob.12086. Disponível em: http://doi.wiley.com/10.1111/glob.12086.

BAUMANN, Henrikke; TILLMAN, Anne-Marie. The Hitch Hiker's Guide to LCA - An orientation in LCA methodology and application. Lund, Sweden: Studentlitteratur AB, 2004. 
BELSO-MARTÍNEZ, José Antonio. Differences in Survival Strategies among Footwear Industrial Districts: The Role of International Outsourcing. European Planning Studies, [S. l.], v. 16, n. 9, p. 1229-1248, 2008. DOI: 10.1080/09654310802401649. Disponível em: http://www.tandfonline.com/doi/abs/10.1080/09654310802401649.

BENSADOUN, F.; VERPOEST, I.; BAETS, J.; MÜSSIG, J.; GRAUPNER, N.; DAVIES, P.; GOMINA, M.; KERVOELEN, A.; BALEY, C. Impregnated fibre bundle test for natural fibres used in composites. Journal of Reinforced Plastics and Composites, [S. l.], v. 36, n. 13, p. 942-957, 2017. DOI: 10.1177/0731684417695461. Disponível em: http://journals.sagepub.com/doi/10.1177/0731684417695461.

BHAVYA, K. S.; RAJI, P.; SELVARANI, J. A.; SAMROT, A. V.; JAVAD, T. M. P.; APPALARAJU, V. V. S. S. Leather Processing, Its Effects on Environment and Alternatives of Chrome Tanning. International Journal of Advanced Research in Engineering and Technology, [S. l.], v. 10, n. 6, p. 69-79, 2019. DOI: 10.34218/IJARET.10.6.2019.009. Disponível em: http://iaeme.com/MasterAdmin/Journal_uploads/IJARET/VOLUME_10_ISSUE_6/IJARET_ 10_06_009.pdf.

BLAGA, Mirega; MARMARALI, Arzu; MIHAI, Aura. Functional knitted fabrics for footwear linings. Tekstil ve Konfeksiyon, [S. l.], v. 21, n. 1, p. 30-35, 2011.

BLAGA, Mirela; CIOBANU, Ana Ramona; MARMARALI, Arzu; ERTEKIN, Gözde; ÇELIK, Pinar. Investigation of the physical and thermal comfort characteristics of knitted fabrics used for shoe linings. Tekstil ve Konfeksiyon, [S. l.], v. 25, n. 2, p. 111-118, 2015.

BNDS. A indústria calçadista no Brasil. [s.l: s.n.]. Disponível em: https://www.bndes.gov.br/SiteBNDES/export/sites/default/bndes_pt/Galerias/Arquivos/conhe cimento/setorial/informe-01AI.pdf.

BODĬRLĂU, Ruxanda; TEACĂ, Carmen Alice; SPIRIDON, Iuliana. Preparation and characterization of composites comprising modified hardwood and wood polymers/poly(vinyl chloride). BioResources, $[S . \quad l],$.$\quad v. 4, \quad$ n. $4, \quad$ p. 1285-1304, 2009. DOI: 10.15376/biores.4.4.1285-1304.

BORCHARDT, Miriam; WENDT, Marcos Henrique; SELLITTO, Miguel Afonso; PEREIRA, Giancarlo Medeiros. Reprojeto do contraforte: um caso de aplicação do ecodesign em manufatura calçadista. Production, [S. l.], v. 20, n. 3, p. 392-403, 2010. DOI: 10.1590/s010365132010005000006.

BRANTHWAITE, Helen; CHOCKALINGAM, Nachiappan. Everyday footwear: An overview of what we know and what we should know on ill-fitting footwear and associated pain and pathology. Foot, [S. l.], v. 39, p. 11-14, 2019. DOI: 10.1016/j.foot.2019.01.007. Disponível em: https://doi.org/10.1016/j.foot.2019.01.007.

BRANTHWAITE, Helen; CHOCKALINGAM, Nachiappan; GREENHALGH, Andrew. The effect of shoe toe box shape and volume on forefoot interdigital and plantar pressures in healthy females. Journal of Foot and Ankle Research, [S. l.], v. 6, n. 1, p. 28, 2013. DOI: 10.1186/1757-1146-6-28. Disponível https://jfootankleres.biomedcentral.com/articles/10.1186/1757-1146-6-28.

em:

BRASIL. Tabela de incidência do imposto sobre produtos industrializados. [s.d.]. Disponível em: http://camex.gov.br/. Acesso em: 5 mar. 2020. 
BRASIL. Política Nacional de Resíduos Sólidos. 3. ed. Brasília: Câmara dos Deputados, 2017.

BREDA, Francisco de Assis. Proposta de um modelo de gestão de resíduos industriais para o setor calçadista de Franca-SP com vistas à Política Nacional de Resíduos. 2016. Universidade de São Paulo, [S. l.], 2016. Disponível em: https://www.teses.usp.br/teses/disponiveis/96/96132/tde-12072016-105138/pt-

br.php\#: :text=Países como Alemanha e Estados,resíduos desde os anos 1970.\&text=Dessa forma\%2C o objetivo desta,Política Nacional de Resíduos Sólidos.

BUCKLOW, Joy; PERRY, Patsy; RITCH, Elaine. The Influence of Eco-Labelling on Ethical Consumption of Organic Cotton. In: Sustainability in Fashion. Cham: Springer International Publishing, 2017. p. 55-80. DOI: 10.1007/978-3-319-51253-2_4. Disponível em: http://link.springer.com/10.1007/978-3-319-51253-2_4.

CALÇADOS, Casanova. Casanova Calçados. 2019. Disponível em: https://www.instagram.com/casanovacalcados/?hl=pt-br. Acesso em: 12 abr. 2020.

CALTECH, Nicolet. FT-IR User's Guide. [s.d.]. Disponível em: http://mmrc.caltech.edu/. Acesso em: 20 ago. 2020.

CAMEX. Diário Oficial da União. 2010. Disponível em: http://pesquisa.in.gov.br/imprensa/jsp/visualiza/index.jsp?data=05/03/2010\&jornal=1\&pagina =13\& totalArquivos=192. Acesso em: 14 abr. 2019.

CAMPOS, Luísa; AXINN, Catherine; FREEMAN, Susan; SUDER, Gabriele. Chapter 13: Motivations to Internationalise: Evidence from Brazilian Shoe Firms. In: Key Success Factors of SME Internationalisation: A Cross-Country Perspective. Bingley: Emerald Publishing Limited, 2018. p. 225-247. DOI: 10.1108/S1876-066X20180000034013. Disponível em: https://www.emerald.com/insight/content/doi/10.1108/S1876-

066X20180000034013/full/html.

CAMPOS, Silvia Horst; CALANDRO, Maria Lucrécia. Nova configuração do mercado internacional de calçados e os impactos sobre a indústria calçadista gaúcha. Ensaios FEE, [S. l.], v. 30, p. 517-546, 2009. Disponível em: https://revistas.fee.tche.br/index.php/ensaios/article/view/2320/2679.

CARMO, Judite de Azevedo. O Comércio no Arranjo Produtivo Local Calçadista de Franca ( SP ). 2012. Universidade Estadual Paulista, [S. l.], 2012.

CARVALHO, Rafaela Nogueira; SAMPAIO, Patrícia Regina. The profile of the Brazilian over indebted consumer in the economic crisis worsening: A comparative analysis 2014-2016. Revista de Estudos Empíricos em Direito, [S. l.], v. 6, n. 1, p. 44-60, 2019. DOI: 10.19092/reed.v6i1.266. Disponível em: https://reedrevista.org/reed/article/view/266.

CARVALHO, Tereza C. M. B.; RIEKSTIN, Ana C.; FRANCISCO, Gabriela A.; GUIMARÃES, Ilse. Sustainable Origin Seal - Increasing the Brazilian Footwear Sector International Competitiveness. International Journal of Sustainable Energy Development, [S. l.], v. 3, n. 1, p. 136-146, 2014. DOI: 10.20533/ijsed.2046.3707.2014.0019.

CASTRO, Inez; MOREIRA, Carlos. Reestruturação da indústria de calçados na Região Nordeste nas décadas 1990/2000. Revista Econômica do Nordeste, [S. l.], v. 40, n. 4, p. 851868,2009 . a.

CASTRO, Inez Sílvia Batista; MOREIRA, Carlos Américo Leite. Reestruturação da Indústria 
de Calçados na Região Nordeste nas Décadas 1990 / 2000. Revista Econômica do Nordeste, [S. l.], v. 40, n. 4, p. 851-868, 2009. b.

CAVALHEIRO, Gabriel Marcuzzo Do Canto; BRANDAO, Mariana. Assessing the IP portfolio of industrial clusters: The case of the Brazilian footwear industry. Journal of Manufacturing Technology Management, [S. l.], v. 28, n. 8, p. 994-1010, 2017. DOI: 10.1108/JMTM-10-2016-0137.

CHANGSHU DAFA WARP KNITTING CO. LTD. Spacer Fabric. [s.d.]. Disponível em: https://www.globalsources.com/si/AS/Changshu-Dafa/6008825089660/pdtl/Spacer-

Fabric/1039717723.htm. Acesso em: 13 maio. 2020.

CHATZISTERGOS, Panagiotis E.; GATT, Alfred; FORMOSA, Cynthia; FARRUGIA, Kurt; CHOCKALINGAM, Nachiappan. Optimised cushioning in diabetic footwear can significantly enhance their capacity to reduce plantar pressure. Gait \& Posture, [S. l.], v. 79, p. 244-250, 2020. DOI: 10.1016/j.gaitpost.2020.05.009. Disponível em: https://linkinghub.elsevier.com/retrieve/pii/S0966636220301594.

CHINA, Cecilia Rolence; MAGUTA, Mihayo Musabila; NYANDORO, Stephen Samwel; HILONGA, Askwar; KANTH, Swarna V.; NJAU, Karoli N. Alternative tanning technologies and their suitability in curbing environmental pollution from the leather industry: A comprehensive review. Chemosphere, [S. l.], v. 254, p. 126804, 2020. DOI: 10.1016/j.chemosphere.2020.126804.

CHROBOT, P.; FAIST, M.; GUSTAVUS L. Measuring Fashion 2018 - Environmental Impact of the Global Apparel and Footwear Industries. Study Full report and methodological considerations. 2018. Disponível em: https:/quantisintl.com/report/measuring-fashion-report/. Acesso em: 10 mar. 2020.

CICB. Brazilian Leather Book 2014. [s.l: s.n.].

CICB. Exportações brasileiras de couros e peles. [s.l: s.n.]. Disponível em: http://cicb.org.br/storage/files/repositories/phpOpTS17-total-exp-dez18-vr.pdf.

CICERO, Elaine Cristina. A indústria de calçados de Birigui : origem, reestruturação produtiva e formação de uma economia de aglomeração. 2011. Universidade Estadual Paulista, [S. l.], 2011.

CORTE-RODRIGUEZ, H. de La; RODRIGUEZ-MERCHAN, E. C. The current role of orthoses in treating haemophilic arthropathy. Haemophilia, [S. l.], v. 21, n. 6, p. 723-730, 2015. DOI: $10.1111 /$ hae.12779.

COSTA, Ana Cristina Rodrigues Da; ROCHA, Érico Rial Pinto Da. Panorama da cadeia produtiva têxtil e de confeções e a questão da inovação. [s.l: s.n.]. Disponível em: https://web.bndes.gov.br/bib/jspui/bitstream/1408/1964/2/BS 29_Panorama da cadeia produtiva têxtil_P.pdf.

COSTA, Célia Regina Da. Uma análise nos principais aspectos da construção calçadista para o desenvolvimento de um solado protótipo feito a partir de fibra de coco. 2013. University of São Paulo, [S. l.], 2013.

COSTA, Maria Izabel. Transformação do nãotecido - uma abordagem do design têxtil em produtos de moda. 2003. Universidade Federal de Santa Catarina, [S. l.], 2003.

COSTA, Sérgio L.; MENDONÇA, João P.; PEIXINHO, Nuno. Study on the impact behaviour 
of a new safety toe cap model made of ultra-high-strength steels. Materials and Design, [S. l.], v. 91, p. 143-154, 2016. DOI: 10.1016/j.matdes.2015.11.082.

DAANEN, H. Physiological strain and comfort in sports clothing. In: Textiles for sportswear. [s.1.] : Woodhead Publishing Limited; The Textile Institute, 2015. p. 153-168.

DANIEL W. W. Hypothesis testing. In: Biostatistics. 7. ed. New York, NY: John Wiley and Sons, 2002. p. 204-294.

DAVIA-ARACIL, Miguel; JIMENO-MORENILLA, Antonio; SALAS, Faustino. A new methodological approach for shoe sole design and validation. International Journal of Advanced Manufacturing Technology, [S. l.], v. 86, n. 9-12, p. 3495-3516, 2016. DOI: 10.1007/s00170-016-8427-5.

DE AQUIM, Patrice M.; HANSEN, Éverton; GUTTERRES, Mariliz. Water reuse: An alternative to minimize the environmental impact on the leather industry. Journal of Environmental Management, [S. l.], v. 230, n. October 2018, p. 456-463, 2019. DOI: 10.1016/j.jenvman.2018.09.077.

DE PAIVA, Fábio Friol Guedes; DE MARIA, Vitor Peixoto Klienchen; TORRES, Giovani Barrera; DOGNANI, Guilherme; DOS SANTOS, Renivaldo José; CABRERA, Flávio Camargo; JOB, Aldo Eloizo. Sugarcane bagasse fiber as semi-reinforcement filler in natural rubber composite sandals. Journal of Material Cycles and Waste Management, [S. l.], v. 21, n. 2, p. 326-335, 2019. DOI: 10.1007/s10163-018-0801-y. Disponível em: http://link.springer.com/10.1007/s10163-018-0801-y.

DE PAOLI, Marco Aurelio; WALDMAN, Walter Ruggeri. Bio-based additives for thermoplastics. Polimeros, [S. l.], v. 29, n. 2, p. 1-12, 2019. DOI: 10.1590/0104-1428.06318.

DE SMET, David; GOETHALS, Frederik; DEMEDTS, Brecht; UYTTENDAELE, Willem; VANNESTE, Myriam. Bio-based textile coatings and composites. In: Biobased Products and Industries. Ghent, Belgium: Elsevier, 2020. p. 357-402. DOI: 10.1016/B978-0-12-8184936.00010-5. Disponível https://linkinghub.elsevier.com/retrieve/pii/B9780128184936000105.

DEDAVID, Berenice Anina; GOMES, Carmem Isse; MACHADO, Giovanna. Microscopia eletrônica de varredura : aplicações e preparação de amostras : materiais poliméricos, metálicos e semicondutores. Porto Alegre: EDIPUCRS, 2007.

DEVI, Sarita; SINGH, Vivek; PUNIA, Parveen; ARYA, Nisha. Existing trends of trimming for apparels. ASIAN JOURNAL OF HOME SCIENCE, [S. l.], v. 13, n. 1, p. 280-285, 2018. DOI: $\quad 10.15740 / H A S / A J H S / 13.1 / 280-285 . \quad$ Disponível em: http://www.researchjournal.co.in/online/AJHS/AJHS 13(1)/13_280-285_A.pdf.

DOMÍNGUEZ-MORALES, Manuel J.; LUNA-PEREJÓN, Francisco; MIRÓ-AMARANTE, Lourdes; HERNÁNDEZ-VELÁZQUEZ, Mariló; SEVILLANO-RAMOS, José L. Smart footwear insole for recognition of foot pronation and supination using neural networks. Applied Sciences, [S. l.], v. 9, n. 19, 2019. DOI: 10.3390/app9193970.

DOMJANIC, Jacqueline; WALLNER, Bernard. Increasing Women's Attractiveness : High Heels , Pains and Evolution - A GMM Based Study. In: 8TH INTERNATIONAL TEXTILE, CLOTHING \& DESIGN CONFERENCE - MAGIC WORLD OF TEXTILES 2016, Anais [...]. [s.1: s.n.] p. 243-248.

DREGER, Ademir Anildo; BARBOSA, Luiz Antônio; SANTANA, Ruth Marlene 
Campomanes; SCHNEIDER, Eduardo Luis; MORISSO, Fernando Dal Pont. Caracterização mecânica e morfológica de solados produzidos com resíduos de laminados de PVC da indústria calçadista. Revista Materia, [S. l.], v. 23, n. 1, 2018. DOI: 10.1590/s1517707620170001.0288.

https://www.researchgate.net/publication/323558587_Caracterizacao_mecanica_e_morfologi ca_de_solados_produzidos_com_residuos_de_laminados_de_PVC_da_industria_calcadista.

DUARTE, Isadora. Entidade volta atrás e nega suspensão de compras de couro brasileiro. O Estado de São Paulo, São Paulo - Brasil, 2019. Disponível em: https://sustentabilidade.estadao.com.br/noticias/geral,pelo-menos-18-marcas-comotimberland-e-kipling-suspendem-compra-de-couro-do-brasil,70002985937.

DUNOFF, JEFFREY L.; MOORE, MICHAEL O. Footloose and duty-free? Reflections on European Union - Anti-Dumping Measures on Certain Footwear from China. World Trade Review, [S. l.], v. 13, n. 02, p. 149-178, 2014. DOI: 10.1017/s1474745614000056.

DWIVEDI, Rish; CHAKRABORTY, Shankar. Strategic decision making for a footwear industry using activity based costing and value chain models. Jounal of Management Accounting, [S. l.], v. 17, p. 119-128, 2017.

ELANCHEZHIAN, C.; RAMNATH, B. Vijaya; RAMAKRISHNAN, G.; RAJENDRAKUMAR, M.; NAVEENKUMAR, V.; SARAVANAKUMAR, M. K. Review on mechanical properties of natural fiber composites. Materials Today: Proceedings, [S. l.], v. 5, n. 1, p. 1785-1790, 2018. DOI: 10.1016/j.matpr.2017.11.276. Disponível em: https://doi.org/10.1016/j.matpr.2017.11.276.

ELNAGGAR, M. Y.; FATHY, E. S.; HASSAN, M. M. Investigation of physico-mechanical properties of flexible poly (vinyl chloride) filled with antimony trioxide using ionizing radiation. Env.Tech., $[S . \quad$ l. $], \quad$ v. 40, p. 3054-3061, 2019. DOI: https://doi.org/10.1080/09593330.2018.1461247.

ENTRETEX. Couraça e Contraforte. 2015. Disponível em: http://entretex.com.br/site/?page_id=272. Acesso em: 13 abr. 2020.

EUROPEAN PARLIAMENT. COMMISSION REGULATION (EC) No 552/2009. 2009. Disponível em: https://eurlex.europa.eu/LexUriServ/LexUriServ.do?uri=OJ:L:2009:164:0007:0031:EN:PDF. Acesso em: 15 abr. 2020.

FARIA, José Wagner; PACHECO, Walter Alves Ferrari. Guia técnico ambiental de curtumes. 2. ed. São Paulo: CETESB, 2015.

FARUK, Omar; BLEDZKI, Andrzej K.; FINK, Hans Peter; SAIN, Mohini. Progress report on natural fiber reinforced composites. Macromolecular Materials and Engineering, [S. l.], v. 299, n. 1, p. 9-26, 2014. DOI: 10.1002/mame.201300008.

FEIPLASTIC. O evento. 2020. Disponível em: https://www.feiplastic.com.br/pt-br/oevento.html. Acesso em: 30 abr. 2020.

FERREIRA, Marcia Christina; SCARABOTO, Daiane. "My plastic dreams": Towards an extended understanding of materiality and the shaping of consumer identities. Journal of Business Research, [S. l.], v. 69, n. 1, p. 191-207, 2016. DOI: 10.1016/j.jbusres.2015.07.032. Disponível em: http://dx.doi.org/10.1016/j.jbusres.2015.07.032.

FERREIRA, Maria J.; FREITAS, Fernanda; ALMEIDA, Manuel F. The Effect of leather fibers 
on the properties of rubber-leather composites. Journal of Composite Materials, [S. l.], v. 44, n. 24, p. 2801-2817, 2010. DOI: 10.1177/0021998310369597.

FIGUEIREDO, Camila Jesus De; URMÉNYI, Fernanda Gouvêa Gomes. Cloreto de vinila, C2H3Cl. [s.d.]. Disponível em: http://qnint.sbq.org.br/qni/popup_visualizarMolecula.php?id=RQnm8gMED07F4mzbE1zhMI ANmKvd1-bcJRmf5usptCLD39GnnxfasQJ9yIEURU7oaQCBmlfD6Vx561zXiws-lw==. Acesso em: 1 out. 2020.

FLORES, Giovana Domingues. The men footwear industry in Brazil: challenges and opportunities. 2018. Fundação Getúlio Vargas, [S. l.], 2018. Disponível em: http://bibliotecadigital.fgv.br/dspace/handle/10438/24899.

FORTEA-VERDEJO, Marta; BUMBARIS, Elias; BURGSTALLER, Christoph; LEE, Koonyang; BUMBARIS, Elias; BURGSTALLER, Christoph. Plant fibre-reinforced polymers : where do we stand in terms of tensile properties? International Materials Reviews, [S. l.], v. 6608, n. September, p. 441-464, 2017. DOI: 10.1080/09506608.2016.1271089.

GÁRCIA-DIÉGUEZ, Carlos; HERVA, Marta; ROCA, Enrique. A decision support system based on fuzzy reasoning and AHP-FPP for the ecodesign of products: Application to footwear as case study. Applied Soft Computing, [S. l.], v. 26, p. 224-234, 2015. DOI: https://doi.org/10.1016/j.asoc.2014.09.043.

GAZZOLA, Patrizia; PAVIONE, Enrica; PEZZETTI, Roberta; GRECHI, Daniele. Trends in the fashion industry. The perception of sustainability and circular economy: A gender/generation quantitative approach. Sustainability (Switzerland), [S. l.], v. 12, n. 7, p. 1-19, 2020. DOI: 10.3390/su12072809.

GODWIN, Allen D. Plasticizers. In: Applied Plastics Engineering Handbook. [s.1.] : Elsevier, 2011. p. 487-501. DOI: 10.1016/B978-1-4377-3514-7.10028-5. Disponível em: https://linkinghub.elsevier.com/retrieve/pii/B9781437735147100285.

GONI, Joklan; KADARUSMAN, Yohanes. Local Company Contribution within Global Value Chain: A Case Study in the Indonesian Footwear Industry. Mediterranean Journal of Social Sciences, [S. l.], v. 6, n. 6, p. 444-453, 2016. DOI: 10.5901/mjss.2015.v6n6s5p444.

GONZÁLEZ ELENA, María Luisa; CÓRDOBA-FERNÁNDEZ, Antonio. Footwear fit in schoolchildren of southern Spain: A population study. BMC Musculoskeletal Disorders, [S. l.], v. 20, n. 1, p. 1-7, 2019. DOI: 10.1186/s12891-019-2591-3.

GOTTFRIDSSON, Marie; ZHANG, Yuqing. Environmental impacts of shoe consumption Combining product flow analysis with an LCA model for Sweden. 2015. Chalmers University of Technology, [S. l.], 2015.

GRACIA, Verónica Baena; WINKELHEUS, Katharina. The Next Revolution in Mass Customization: An insight into the sneaker market. La Próxima Revolución en la Personalización Masiva : Una visión en el mercado de las zapatillas de deporte. International Journal of Marketing, Communication and New Media, [S. l.], v. 4, n. June, p. 85-104, 2016.

GUIDOLIN, Silvia Maria; CRISTINA, Ana; ROCHA, Rial Pinto Da. Indústria calçadista e estratégias de fortalecimento da competitividade. BNDS Setorial, [S. l.], v. 31, p. 147-184, 2010.

GUIMARÃES, Bárbara Maria Gama. Estudo das características físico-químicas de fibras 
têxteis vegetais de espécies de Malvaceae. 2014. Universidade de São Paulo, [S. l.], 2014.

GUIMARÃES, Ilse Maria Biason. Panorama do complexo calçadista e coureiro: contexto e perspectivas. $2018 . \quad$ Disponível em: http://feiplar.com.br/pos_feira/apresentacoes/dia07/calcadista/painel_calcadista_assintecal.pdf . Acesso em: 15 fev. 2020.

GUISE, Olivier; STROM, Carl; PRESCHILLA, Nisha. STEM-in-SEM method for morphology analysis of polymer systems. Polymer, [S. l.], v. 52, n. 5, p. 1278-1285, 2011. DOI: 10.1016/j.polymer.2011.01.030. Disponível em: https://linkinghub.elsevier.com/retrieve/pii/S0032386111000383.

GULBINIENE, Ada; JANKAUSKAITE, Virginija; SACEVICIENE, Virginija; MICKUS, Kazys Vytautas. Investigation of water vapour resorption/desorption of textile laminates. Materials Science-Medziagotyra, [S. l.], v. 13, n. 3, p. 255-261, 2007.

GUNAWAN, Theresia; JACOB, Jojo; DUYSTERS, Geert. Network ties and entrepreneurial orientation: Innovative performance of SMEs in a developing country. International Entrepreneurship and Management Journa, [S. l.], n. March, 2015. DOI: 10.1007/s11365014-0355-y.

GUO, Shu; CHOI, Tsan-Ming; SHEN, Bin. Green product development under competition: A study of the fashion apparel industry. European Journal of Operational Research, [S. l.], v. 280, n. 2, p. 523-538, 2020. DOI: 10.1016/j.ejor.2019.07.050. Disponível em: https://linkinghub.elsevier.com/retrieve/pii/S0377221719306290.

HARRIS, Daniel C. Quantitative chemical analysis. 7a. ed. New York: W. H. Freeman and Company, 2007.

HART, Christopher W. L. Mass customization: Conceptual underpinnings, opportunities and limits. International Journal of Service Industry Management, [S. l.], v. 6, n. 2, p. 36-45, 1995. DOI: $10.1108 / 09564239510084932$.

HERRING, Kirk. Athletic Footwear and Orthoses in Sports Medicine. Werd, Matt ed. New York, NY: Springer New York, 2010. DOI: 10.1007/978-0-387-76416-0. Disponível em: http://link.springer.com/10.1007/978-0-387-76416-0.

HERVA, Marta; ÁlVAREZ, Antonio; ROCA, Enrique. Sustainable and safe design of footwear integrating ecological footprint and risk criteria. Journal of Hazardous Materials, [S. l.], v. 192, n. 3, p. 1876-1881, 2011. DOI: 10.1016/j.jhazmat.2011.07.028.

HESSAS, S.; BEHR, M.; RACHEDI, M.; BELAIDI, I. Heel lifts stiffness of sports shoes could La rigidité des talonnettes à plan incliné des chaussures de. Science \& Sports, [S. l.], v. 33, p. 43-50, 2018. DOI: https://doi.org/10.1016/j.scispo.2017.04.015.

HM REVENUE \& CUSTOMS. Classifying footwear for import and export. 2015. Disponível em: https://www.gov.uk/guidance/classifying-footwear. Acesso em: 10 mar. 2020.

HOAI, Nguyen Trong; TOAN, Nguyen Truong; VAN, Pham Hoang. Trade Diversion as Firm Adjustment to Trade Policy: Evidence from EU Anti-dumping Duties on Vietnamese Footwear. World Economy, [S. l.], v. 40, n. 6, p. 1128-1154, 2017. DOI: 10.1111/twec.12421.

HOOKER, Giles. Generalized Functional ANOVA Diagnostics for High-Dimensional Functions of Dependent Variables. Journal of Computational and Graphical Statistics, [S. l.], v. 16, n. 3, p. 709-732, 2007. DOI: 10.1198/106186007X237892. Disponível em: 
http://www.tandfonline.com/doi/abs/10.1198/106186007X237892.

HOUCK, Max M. Identification of textile fibers. Cambridge, England: Woodhead Publishing in Textiles, 2009.

HUSSAIN, Akil. Performance and Prospects of Indian Footwear Industries. Business DimensionsAn, [S. l.], v. 3, n. 1, p. 2348-2737, 2016. Disponível em: http://businessdimensions.org/dnload/Akil-Hussain/BDV03I01P0001.pdf.

IBGE. Demografia das Empresas - Brasil 2013. Rio de Janeiro.

IFSC JARAGUÁ DO SUL. Novo tear listrador do curso de malharia. 2015. Disponível em: https://www.youtube.com/watch?v=p7j0tNy7dpI. Acesso em: 6 maio. 2020.

INDA. About Nonwovens. [s.d.]. Disponível em: https://www.inda.org/about-nonwovens/. Acesso em: 30 mar. 2020.

INSPIRAMAIS. Inspiramais: espaço de sustentabilidade apresentará tecnologias com preocupação ambiental e social. 2019. Disponível em: https://www.inspiramais.com.br/conteudo/1881/inspiramais-espaco-de-sustentabilidadeapresentara-tecnologias-com-preocupacao-ambiental-e-social. Acesso em: 12 jun. 2020.

INSPIRAMAIS. O salão. 2020. Disponível em: https://www.inspiramais.com.br/o-salao. Acesso em: 12 jun. 2020.

IPT. Análise DSC e Termogravimétrica - TGA. [s.d.]. Disponível em: https://www.ipt.br/solucoes/complementos/40/317-

seguranca_contra_explosoes_em_processos_industriais_armazenamentos_e_transporte_.htm. Acesso em: 29 jul. 2020.

ITMA. About. 2019. Disponível em: https://www.itma.com/about-itma/itma-2019. Acesso em: 13 maio. 2020.

JANKAUSKAITÉ, Virginija; GULBINIENĖ, Ada; KONDRATAS, Alvydas; DOMSKIENE், Jurgita; URBELIS, Virginijus. Influence of the Structure of Footwear Upper and Lining Materials on Their Electrical Properties. Fibres and Textiles in Eastern Europe, [S. l.], v. 26, n. 2(128), p. 87-92, 2018. DOI: 10.5604/01.3001.0011.5744. Disponível em: https://ftee.publisherspanel.com/gicid/01.3001.0011.5744.

JIANG, Huiyan; LIU, Junsheng; HAN, Wei. The status and developments of leather solid waste treatment: A mini-review. Waste Management and Research, [S. l.], v. 34, n. 5, p. 399-408, 2016. DOI: $10.1177 / 0734242 X 16633772$.

KARAVANA, Hüseyin Ata; ADIGUZEL ZENGING, Arife Candas; BAKILER, Gökce; AKPOLAT, Fatma; ERDOGAN, Fatma; YILMAZ, Onur; SEYDIBEYOGLU, Mehmet Ozguz. The use of vegetable fillers as reinforcement material in SBR based bio-composites. In: ANNALS OF THE UNIVERSITY OF ORADEA FASCICLE OF TEXTILES, LEATHERWORK 2017, Anais [...]. [s.1: s.n.] p. 161-166. Disponível em: https://pdfs.semanticscholar.org/0b5a/0f7c9602f27ce8cae0983f3e481fa21ae71e.pdf?_ga=2.16 5115327.1418030856.1596661704-1188834409.1595782165.

KARINA. Quem somos. [s.d.]. Disponível em: https://www.karina.com.br/quem-somos/. Acesso em: 7 abr. 2020.

KARLMAYER. Double needle bar raschel machines - 4D-knit.solutions - RDPJ 6/2 EL. [s.d.]. Disponível em: https://www.karlmayer.com/en/products/warp-knitting- 
machines/double-needle-bar-raschel-machines/4d-knit-solutions/\#panel2649. Acesso em: 6 maio. 2020.

KARLMAYER. RD 7/2-12 EN. 2014. Disponível em: https://www.karlmayer.com/en/products/warp-knitting-machines/double-needle-bar-raschelmachines/spacer-textiles/. Acesso em: 5 maio. 2020.

KAYSER, Pedro Augusto Bittencourt. The Brazilian shoe industry and the Chinese competition in international markets. 2008. Ohio University, [S. l.], 2008.

KLIMIEC, E.; JASIEWICZ, B.; PIEKARSKI, J.; ZARASKA, K.; GUZDEK, P.; KOŁASZCZYŃSKI, G. Measuring of foot plantar pressure - Possible applications in quantitative analysis of human body mobility. Measurement Science and Technology, [S. l.], v. 28, n. 5, 2017. DOI: 10.1088/1361-6501/aa60a9.

KOHAN, Lais; MARTINS, Cristiane Reis; OLIVEIRA DUARTE, Larissa; PINHEIRO, Luciano; BARUQUE-RAMOS, Julia. Panorama of natural fibers applied in Brazilian footwear: materials and market. SN Applied Sciences, [S. l.], v. 1, n. 8, p. 895, 2019. DOI: 10.1007/s42452-019-0927-0.

KOHAN, Lais; SANTOS, Heloisa Nazaré Dos; MARTINS, Cristiane Reis; FERNANDES, Palloma Renny Beserra; BRANDAO, Fernando; BARUQUE-RAMOS, Julia. Brazilian Sustainability Outlook in Footwear Sector. In: MUTHU, S. S. (org.). Leather and Footwear Sustainability. [s.1.] : Springer Singapore, 2020. p. 199-160. DOI: 10.1007/978-981-15-62969_9.

KUNIZSHOES. What makes a good walking shoe? 2016. Disponível em: https://kunitzshoes.ca/2016/05/makes-good-walking-shoe/. Acesso em: 13 abr. 2020.

LAKTIM, Mariana Costa. Cama, mesa e banho: desenvolvimento de materiais e processos têxteis, design e moda no Brasil (1976-2017). 2018. Universidade de São Paulo, [S. l.], 2018. Disponível em: https://teses.usp.br/teses/disponiveis/100/100133/tde-31102018172203/publico/MarianaLaktimCMB.pdf.

LAN, Thi Hoang Phuong; HONG, THI, Pham Thanh. An Analysis of Vietnamese Footwear Manufacturers' Participation in the Global Value Chain Where They Are and Where They Should Proceed? VNU Journal of Science: Education Research, [S. l.], v. 32, n. 5E, p. 5565, 2016. Disponível em: http://repository.vnu.edu.vn/bitstream/VNU_123/55507/1/An Analysis of Vietnamese Footwear Manufacturers' Participation in the Global Value Chain Where They Are and Where They Should Proceed.pdf.

LEAL, Olga Benário Ramos. Análise Técnica, Econômica e de Tendências da Indústria do Couro Brasileira e da sua Relação com a Indústria Química. 2007. Universidade Federal do Rio de Janeiro, [S. l.], 2007.

LEE, Chang-Min; JEONG, Eun-Hee; FREIVALDS, Andris. Biomechanical effects of wearing high-heeled shoes. International Journal of Industrial Ergonomics, [S. l.], v. 28, n. 6, p. 321-326, 2001. DOI: 10.1016/S0169-8141(01)00038-5.

LEE, Michael James; RAHIMIFARD, Shahin. An air-based automated material recycling system for postconsumer footwear products. Resources, Conservation and Recycling, [S. l.], v. 69, p. 90-99, 2012. DOI: 10.1016/j.resconrec.2012.09.008. Disponível em: https://linkinghub.elsevier.com/retrieve/pii/S0921344912001693.

LEVINE, David. Athletic Shoe Evaluation. In: WERD, Matthew B.; KNIGHT, E. Leslie (org.). 
Athletic Footwear and Orthoses in Sports Medicine. [s.1.] : Springer, 2010. p. 55-62. DOI: 10.1007/978-0-387-76416-0.

LEWINSON, Ryan T.; WOROBETS, Jay T.; STEFANYSHYN, Darren J. Control conditions for footwear insole and orthotic research. Gait and Posture, [S. l.], v. 48, p. 99-105, 2016. DOI: $\quad 10.1016 /$ j.gaitpost.2016.04.012. Disponível em: http://dx.doi.org/10.1016/j.gaitpost.2016.04.012.

LI, Xinxin; ZHANG, Aijun; JIANG, Gaoming. Design of Rascheltronic Vamp Fabric with Double-Color Pitting Effect. FIBRES \& TEXTILES in Eastern Europe, [S. l.], v. 3, n. 123, p. 92-97, 2017. DOI: 10.5604/12303666.1237243.

LIAISON, Caimi. Materiais Summer 2021. 2020. Disponível em: https://caimiliaison.com.br/colecoes/summer-2021/. Acesso em: 10 maio. 2020.

LO, Wai-ting; WONG, Del P.; YICK, Kit-lun; NG, Sun Pui; YIP, Joanne. The biomechanical effects and perceived comfort of textile-fabricated insoles during straight line walking. Prosthetics and Orthotics International, [S. l.], v. 42, n. 2, p. 153-162, 2018. DOI: 10.1177/0309364617696084. Disponível http://journals.sagepub.com/doi/10.1177/0309364617696084.

LOFRANO, Giusy; MERIÇ, Sureyya; ZENGIN, Gülsüm Emel; ORHON, Derin. Chemical and biological treatment technologies for leather tannery chemicals and wastewaters: A review. Science of the Total Environment, [S. l.], v. 461-462, p. 265-281, 2013. DOI: 10.1016/j.scitotenv.2013.05.004.

LOPES, Diana; FERREIRA, Maria J.; RUSSO, Rui; DIAS, Joana M. Natural and synthetic rubber/waste e Ethylene-Vinyl Acetate composites for sustainable application in the footwear industry. Journal of Cleaner Production, [S. l.], v. 92, p. 230-236, 2015. DOI: 10.1016/j.jclepro.2014.12.063. Disponível em: http://dx.doi.org/10.1016/j.jclepro.2014.12.063.

LOSCHIAVO DOS SANTOS, Maria Cecília; VILLAC, Teresa. Law and Public Management of Solid Waste in Brazil. In: Sustainable Resource Recovery and Zero Waste Approaches. [s.1.] : Elsevier, 2019. p. 101-103. DOI: 10.1016/B978-0-444-64200-4.00007-4. Disponível em: https://linkinghub.elsevier.com/retrieve/pii/B9780444642004000074.

LU, Zhiwen; JIANG, Gaoming; CONG, Honglian; YANG, Xi. The Development of the FlatKnitted Shaped Uppers based on Ergonomics. Autex Research Journal, [S. l.], v. 16, n. 2, p. 67-74, 2016. DOI: 10.1515/aut-2015-0029. Disponível em: http://content.sciendo.com/view/journals/aut/16/2/article-p67.xml.

MA, Jianzhong; SHAO, Liang; XUE, Chaohua; DENG, Fuquan; DUAN, Zhouyang. Compatibilization and properties of ethylene vinyl acetate copolymer (EVA) and thermoplastic polyurethane (TPU) blend based foam. Polymer Bulletin, [S. l.], v. 71, n. 9, p. 2219-2234, 2014. DOI: $10.1007 / \mathrm{s} 00289-014-1183-5$.

MALUF, Marcia Luzia F.; HILBIG, Cleonice C. Curtimento Ecológico de Peles de Animais para Agregação de Valor Através da Confecção de Artesanato. Varia Scientia, [S. l.], v. 9, n. 15, p. p.75-79, 2010.

MARAFON, Anderson Carlos; AMARAL, André Felipe Câmara; LEMOS, Eurico Eduardo Pinto De. Characterization of bamboo species and other biomasses with potential for thermal energy generation\&gt; Pesquisa Agropecuária Tropical, [S. l.], v. 49, 2019. DOI: 
em: http://www.scielo.br/scielo.php?script=sci_arttext\&pid=S198340632019000100611\&tlng=en.

MARIANO, Marcia. Perfil do Setor de Têxteis Técnicos no Brasil. Revista Têxtil Técnico Report, [S. l.], v. 3, n. 1, 2014.

MATTANA, Mônica. Influência dos plastificantes alternativos ao dioctil ftalato nas propriedades de compostos de poli (cloreto de vinila). 2017. Universidade Federal do Rio Grande do Sul, [S. l.], 2017. Disponível em: http://hdl.handle.net/10183/172075.

MDCI. Base de dados do Comex Stat. 2020. Disponível em: http://www.mdic.gov.br/index.php/comercio-exterior/estatisticas-de-comercio-exterior/basede-dados-do-comercio-exterior-brasileiro-arquivos-para-download. Acesso em: 20 abr. 2020.

MELISSA. Últimas oportunidades. 2020. Disponível em: https://lojamelissa.com.br/ultimasoportunidades. Acesso em: 25 ago. 2020.

MELO JÚNIOR, Tadeu Artur De; SANTOS, Cristina Dos. Materiais e processo de produção de solados: destinação fianl de resíduos em empresas calçadistas no município de Franca-SP. Diálogos Acadêmicos, $[S . \quad$ l. $]$, v. 12, p. 44-59, 2017. Disponível em: http://uniesp.edu.br/sites/_biblioteca/revistas/20180502083940.pdf.

MELVIN, Jonathan M. A.; PRICE, Carina; PREECE, Stephen; NESTER, Christopher; HOWARD, David. An investigation into the effects of, and interaction between, heel height and shoe upper stiffness on plantar pressure and comfort. Footwear Science, [S. l.], v. 11, n. 1, p. 25-34, 2019. DOI: 10.1080/19424280.2018.1555862.

MH EQUIPAMENTOS. Laboratório. [s.d.]. Disponível em: http://www.mh.ind.br/. Acesso em: 14 abr. 2019a.

MH EQUIPAMENTOS. Prensa Hidráulica de Laboratório. [s.d.]. Disponível em: http://www.mh.ind.br/laboratorio_prensahidraulica.php.

MINITAB INC. Minitab User's Guide 2.State College, PAMinitab Inc, , 2000.

MONTEIRO, Amanda Sousa. Tururi (Manicaria saccifera Gaertn.): caracterização têxtil, processos e técnicas artesanais em comunidade local amazônica (PA - Brasil). 2016. Universidade de São Paulo, São Paulo, 2016. DOI: 10.11606/D.100.2016.tde-04082016144047. Disponível em: http://www.teses.usp.br/teses/disponiveis/100/100133/tde-04082016$144047 /$.

MORGADO, Daniella Lury. Biocompósitos a partir de celulose de linter: filmes de acetatos de celulose/celulose e quitosana/celulose. 2009. Universidade de São Paulo, São Carlos, 2009. DOI: $\quad$ 10.11606/T.75.2009.tde-25022010-152850. Disponível em: http://www.teses.usp.br/teses/disponiveis/75/75131/tde-25022010-152850/.

MOTAWI, Wade. Shoe Material Design Guide: The Shoe Designers Complete Guide to Selecting and Specifying Footwear Materials. [s.1.] : Wade Motawi, 2018.

MUTHU, S. S. The environmental impact of footwear and footwear materials. In: LUXIMON, A. (org.). Handbook of Footwear Design and Manufacture. [s.1.] : Woodhead Publishing Limited, 2013. p. 266-279. DOI: 10.1533/9780857098795.3.266. Disponível em: http://dx.doi.org/10.1533/9780857098795.3.266.

MUZHONG, CAI; YUSHAN, HE. Formula for making antibacterial PVC sole, 
CN107312274, 2017.

NACHTIGALL, Troy Robert; TOMICO, Oscar; WAKKARY, Ron; WENSVEEN, Stephan; VAN DONGEN, Pauline; VAN NOORDEN, Leonie Tenthof. Towards Ultra Personalized 4D Printed Shoes. In: CONFERENCE ON HUMAN FACTORS IN COMPUTING SYSTEMS 2018, New York, NY, USA. Anais [...]. New York, NY, USA: ACM, 2018. p. 1-9. DOI: 10.1145/3170427.3174369. Disponível em: https://dl.acm.org/doi/10.1145/3170427.3174369.

NAGANO, Hanatsu; BEGG, Rezaul K. Shoe-insole technology for injury prevention in walking. Sensors (Switzerland), [S. l.], v. 18, n. 5, 2018. DOI: 10.3390/s18051468.

NALYANYA, Kallen Mulilo; ROP, Ronald; ONYUKA, Arthur; BIRECH, Zephania. Recent use of selected phytochemistry to mitigate environmental challenges facing leather tanning industry: a review. Phytochemistry Reviews, [S. l.], v. 18, n. 5, p. 1361-1373, 2019. DOI: 10.1007/s11101-019-09651-x. Disponível em: https://doi.org/10.1007/s11101-019-09651-x.

NANDIYANTO, Asep Bayu Dani; OKTIANI, Rosi; RAGADHITA, Risti. How to Read and Interpret FTIR Spectroscope of Organic Material. Indonesian Journal of Science and Technology, [S. l.], v. 4, n. 1, p. 97, 2019. DOI: 10.17509/ijost.v4i1.15806. Disponível em: http://ejournal.upi.edu/index.php/ijost/article/view/15806.

NAVARRO, Rodrigo; PÉREZ PERRINO, Mónica; GÓMEZ TARDAJOS, Myriam; REINECKE, Helmut. Phthalate Plasticizers Covalently Bound to PVC: Plasticization with Suppressed Migration. Macromolecules, [S. l.], v. 43, n. 5, p. 2377-2381, 2010. DOI: 10.1021/ma902740t. Disponível em: https://pubs.acs.org/doi/10.1021/ma902740t.

NAZARÉ, Heloisa; ROMEIRO FILHO, Eduardo. Uma experiência em design de produto em uma indústria calçadista de Nova Serrana-MG. Estudos em Design | Revista (online), [S. l.], v. 23, p. 16-36, 2015. Disponível em: https://www.eed.emnuvens.com.br/design/article/view/231/183.

NEBO, M. Functional sport footwear. In: SHISHOO, R. (org.). Textiles in sports. [s.1.] : Woodhead Publishing Limited, 2005. p. 70-84.

NETCADARCOS. Cadarço oval de poliéster. [s.d.]. Disponível em: https://www.netcadarcos.com.br/categorias/cadarcos-oval-de-poliester. Acesso em: 5 maio. 2020.

NIGG, B. M. Biomechanics of Sport Shoes. [S. l.], p. 1-300, 2010.

NIKE. Nike Grind Materials. [s.l: s.n.]. Disponível em: https://www.nikegrind.com/media/doc/Nike_Grind_Materials_Brochure_100919.pdf.

NIKE. Tênis Nike React Phantom Run Flyknit 2 Masculino. 2020. Disponível em: https://www.nike.com.br/Produto/Tenis-Nike-React-Phantom-Run-Flyknit-2-Masculino/153173-176-214366? gridPosition=C1. Acesso em: 12 abr. 2020.

OBER. Parte da transformação para calçados. [s.d.]. Disponível em: http://www.ober.com.br/landings/calcados/. Acesso em: 5 maio. 2020.

OLIVEIRA, Meire; SOARES, Bernardete; BROEGA, Ana Cristina. Design Sustentável aplicado à pele de animal residual da indústria de calçado. In: $3^{\circ}$ INTERNACIONAL FASHION AND DESIGN CONGRESS 2016, Anais [...]. [s.l: s.n.] p. 3620-3628.

ORIGEM SUSTENTÁVEL. Metodologia para implementação dos resquisitos de sustentabilidade. Novo Hamburgo: IBB, 2019. 
ORUKO, R. O.; SELVARAJAN, R.; OGOLA, H. J. O.; EDOKPAYI, J. N.; ODIYO, J. O. Contemporary and future direction of chromium tanning and management in sub Saharan Africa tanneries. Process Safety and Environmental Protection, [S. l.], v. 133, p. 369-386, 2020. DOI: 10.1016/j.psep.2019.11.013.

PAIVA, Fábio Friol Guedes De; MARIA, Vitor Peixoto Klienchen De; TORRES, Giovani Barrera; DOGNANI, Guilherme; SANTOS, Renivaldo José Dos; CABRERA, Flávio Camargo; JOB, Aldo Eloizo. Sugarcane bagasse fiber as semi-reinforcement filler in natural rubber composite sandals. Journal of Material Cycles and Waste Management, [S. l.], 2018. DOI: 10.1007/s10163-018-0801-y. Disponível em: http://dx.doi.org/10.1007/s10163-018-0801-y.

PARIDA, C.; DAS, S. C.; DASH, S. K. Mechanical Analysis of Bio Nanocomposite Prepared from Luffa cylindrica. Procedia Chemistry, $[S$. l.], v. 4, p. 53-59, 2012. DOI: 10.1016/j.proche.2012.06.008. Disponível em: https://linkinghub.elsevier.com/retrieve/pii/S1876619612000095.

PARLAR, Z.; ABDLHAMED, A.; AKKURT. Gamma-ray-shielding properties of composite materials made of recycled sport footwear. International Journal of Environmental Science and Technology, [S. l.], p. 1-4, 2018. DOI: 10.1007/s13762-018-1876-7. Disponível em: https://doi.org/10.1007/s13762-018-1876-7.

PATRA, Deepak Kumar; PRADHAN, Chinmay; PATRA, Hemanta Kumar. Chromium bioaccumulation, oxidative stress metabolism and oil content in lemon grass Cymbopogon flexuosus (Nees ex Steud.) W. Watson grown in chromium rich over burden soil of Sukinda chromite mine, India. Chemosphere, [S. l.], v. 218, p. 1082-1088, 2019. DOI: 10.1016/j.chemosphere.2018.11.211.

PEIXINHO, Nuno; COSTA, Sérgio; MENDONÇA, João. Impact behaviour of safety shoe high strength steel parts. Engineering Transactions, [S. l.], v. 66, n. 2, p. 175-185, 2018.

PELIZZARI, O. Shoe design development. In: A. LUXIMON (org.). Handbook of Footwear Design and Manufacture. [s.1.] : Woodhead Publishing Limited, 2013. p. 117-127.

PENNAS, Lais Gonçalves de Andrade. Caracterização têxtil da fibra do Tucum (Astrocaryum chambira Burret). 2019. Universidade de São Paulo, São Paulo, 2019. DOI: 10.11606/D.100.2019.tde-15102019-181552. Disponível em: http://www.teses.usp.br/teses/disponiveis/100/100133/tde-15102019-181552/.

PEREIRA, Maria Adelina. Manual de têxteis técnicos - classificação, indentificação e aplicações. 2. ed. [s.l.] : Abint, 2005.

PICKERING, K. L.; EFENDY, M. G. Arua.; LE, T. M. A review of recent developments in natural fibre composites and their mechanical performance. Composites Part A, [S. l.], v. 83, p. 98-112, 2016. DOI: 10.1016/j.compositesa.2015.08.038.

PLÁSTICO BRASIL. A Feira. 2019. Disponível em: https://www.plasticobrasil.com.br/pt/afeira.html. Acesso em: 30 abr. 2020.

RABELLO, Marcelo Silveira. Aditivação de polímeros. São Paulo - Brasil: Artliber, 2000.

RAINHA CALÇADOS. Sapato Feminino Beira Rio de Salto Baixo. 2020. Disponível em: https://www.rainhacalcados.com.br/sapato-feminino-beira-rio-bege. Acesso em: 6 maio. 2020.

RAJAMANI, Sengoda Gounder. Growth of leather sector in asian countries and recent environmental developments in world leather sector. In: ICAMS $2014-5 \mathrm{TH}$ 
INTERNATIONAL CONFERENCE ON ADVANCED MATERIALS AND SYSTEMS 2014, Bucharest, Romania. Anais [...]. Bucharest, Romania p. 491-496. Disponível em: https://www.tib.eu/en/search/id/TIBKAT\%3A828822999/Proceedings-of-The-5thInternational-Conference/.

RAJAN, T. Palani; SOUZA, Louis D.; RAMAKRISHNAN, G.; ZAKRIYA, G. Mohamed. Comfort properties of functional warp-knitted polyester spacer fabrics for shoe insole applications. Journal of Industrial Textiles, [S. l.], v. 45, n. 6, p. 1239-1251, 2016. DOI: 10.1177/1528083714557056. Disponível em: http://journals.sagepub.com/doi/10.1177/1528083714557056.

RAJENDRAN, S.; ANAND, S. C. High performance textiles for wound care. In: High Performance Textiles and their Applications. [s.1.] : Elsevier, 2014. p. 190-222. DOI: 10.1533/9780857099075.190. Disponível em: https://linkinghub.elsevier.com/retrieve/pii/B9781845691806500060.

RECEITA FEDERAL. Emissão de Comprovante de Inscrição e de Situação Cadastral. $2018 . \quad$ Disponível em: http://servicos.receita.fazenda.gov.br/Servicos/cnpjreva/Cnpjreva_Solicitacao.asp?cnpj=. Acesso em: 10 jul. 2020.

REMMEN, Arne; JENSEN, Allan Astrup; FRYDENDAL, Jeppe. Life Cycle Management, A Business Guide to Sustainability. Paris: United Nations Environment Programme and Danish Standards, 2007.

RICHIE, Douglas H. Athletic Socks. In: WERD, Matthew B.; KNIGHT, E. Leslie (org.). Athletic Footwear and Orthoses in Sports Medicine. New York, NY: Springer New York, 2010. p. 69-78. DOI: 10.1007/978-0-387-76416-0. Disponível em: http://link.springer.com/10.1007/978-0-387-76416-0.

ROBIN DENIM. The fabric called denim - weaving. 2017. Disponível em: https://robindenim.com/2017/12/fabric-called-denim-weaving/. Acesso em: 5 maio. 2020.

ROCHA, Angela; KURY, Beatriz; TOMASSINI, Rodrigo; VELLOSO, Luciana. Strategic Responses to Environmental Turbulence: A Study of Four Brazilian Exporting Clusters. Investigaciones Regionales-Journal of Regional Research, [S. l.], v. 39, p. 155-174, 2017. Disponível em: https://investigacionesregionales.org/wp-content/uploads/sites/3/2017/12/07ROCHA.pdf.

RODOLFO JUNIOR, Antonio; TSUKAMOTO, Cláudia Takahashi. Tecnologia do PVC. São Paulo - Brasil: Instituto Brasileiro do PVC, 2019.

RODRIGUES, Hildete Flores; SALOMÃO, Ivan Colangelo. O Setor Calçadista do Vale Do Sinos (RS) No Âmbito do Mercosul: Desafios e Potencialidades. Rev. Cadernos de Campo |, [S. l.], v. 24, p. 169-186, 2018.

ROH, Eui Kyung; OH, Kyung Wha; KIM, Seong Hun. Classification of synthetic polyurethane leather by mechanical properties according to consumers' preference for fashion items. Fibers and Polymers, [S. l.], v. 14, n. 10, p. 1731-1738, 2013. DOI: 10.1007/s12221-013-1731-x.

ROLO, Margarida Filipa Gonçalves Araújo. Design de Calçado Do processo criativo à produção. 2016. Universidade Técnica de Lisboa, [S. l.], 2016.

RONCOLETTA, Mariana Rachel. Footwear design for people with physical disabilities: the pleasures of beauty and comfort. 2014. Univesity of São Paulo, [S. l.], 2014. 
SANTANA, Synthia Kariny Silva De. The impact of the international reconfiguration of the footwear market on the Brazilian segment of leather and footwear. Rio de Janeiro: IPEA, 2015. a. v. 2114

SANTANA, Synthia Kariny Silva De. O Impacto da reconfiguração internacional do mercado calçadista sobre o segmento brasileiro de couro e calçados. IPEA - Instituto de Pesquisa Econômica Aplicada, Brasília, v. 2114, p. 24, 2015. b.

SANTOS, Heloisa Nazaré Dos. Processos de produção e trabalho no Arranjo Produtivo Local calçadista de Nova Serrana. GEPROS. Gestão da Produção, Operações e Sistenas, [S. l.], v. $8, \quad$ n. $2, \quad$ p. 55-65, 2013. Disponível em: http://revista.feb.unesp.br/index.php/gepros/article/view/790.

SANTOS, Heliana Marcia; RAZZA, Bruno Montanari; SANTOS, João Eduardo Guarnetti Dos. História da alpargatas: um modelo resistente ao tempo e ao modismo. In: VII CONGRESSO INTERNATIONAL DE HISTÓRIA 2015, Maringá, PR, Brazil. Anais [...]. Maringá, PR, Brazil p. 2043-2055. DOI: 10.4025/7cih.pphuem.1428. Disponível em: http://www.cih.uem.br/anais/2015/trabalhos/1428.pdf.

SCHREIBER, Dusan. Reflective analysis of the organizational culture underlyning innovation by footwear manufactures. Business and Management Review, [S. l.], v. 4, n. 06, p. 1-12, 2015.

SENAI. PPSR - Programa de Proficiência em Susbstâncias Restritas. 2020. Disponível em: https://www.senairs.org.br/PP-Substancias-Restritas. Acesso em: 10 jul. 2020.

SERGIO'S. SAPATO MASCULINO DERBY WHISKY EM COURO. 2020. Disponível em: https://www.lojavirtualsergios.com.br/sapato-masculino-derby-whisky-em-couro-01291655-se-whisky-cacau-parede-b19-20. Acesso em: 29 abr. 2020.

SETHURAMAN, Chidambaram; SRINIVAS, Kota; SEKARAN, Ganesan. Double pyrolysis of chrome tanned leather solid waste for safe disposal and products recovery. International Journal of Scientific \& Engineering Research, [S. l.], v. 4, n. 11, p. 61-67, 2013.

SHAH, Bhargavi. To study the waste caused by discarded footwear in India and finding a solution for the reduction of the same. 2018. National Institute of Fashion Technology Mumbai, [S. l.], 2018.

SIDEWALK. BOTA STONED EVEREST - TAN. 2020. Disponível em: https://www.sidewalklojas.com.br/bota-stoned-everest-tan-01060729/p. Acesso em: 1 abr. 2020.

SILVA, José Augusto Marinho. O design de calçados na (re)evolução digital. Proposta de uma metodologia para análise de desempenho de calçados femininos com foco no conforto do usuário utilizando a modelagem virtual e a impressão 3D. 2016. Universidade de São Paulo, [S. l.], 2016.

SILVA, Marcia Cristina. Análise da inflamabilidade de têxteis de uniformes de aeronautas. 2018. Universidade de São Paulo, [S. l.], 2018. Disponível em: https://teses.usp.br/teses/disponiveis/100/100133/tde-30112018-072259/publico/final.pdf.

SILVA, R. M.; RODRIGUES, J. L.; PINTO, V. V.; FERREIRA, M. J.; RUSSO, R.; PEREIRA, C. M. Evaluation of shock absorption properties of rubber materials regarding footwear applications. Polymer Testing, [S. l.], v. 28, n. 6, p. 642-647, 2009. DOI: 10.1016/j.polymertesting.2009.05.007. 
SINBI. Birigui: história. 2011. Disponível em: http://sindicato.org.br/\#/birigui. Acesso em: 5 out. 2019.

SMITH, Caroline J.; MACHADO-MOREIRA, Cristiano A.; PLANT, GIJSH, George; HODDER, Simon; HAVENITH, George; TAYLOR, Nigel A. S. Design data for footwear: sweating distribution on the human foot. Loughborough University Institutional Repositary, [S. l.], v. 24, n. 3, p. 245-267, 2013. DOI: 10.1243/09596518JSCE509.

SOARES, Graça; MAGALHÃES, Andreia; VASCONCELOS, Alexandra; PINTO, Eugénenia; SANTOS, Jorge. Confort and antibicrobial properties of developed bamboo, polyester and cotton knitted spacer fabrics. Cellulose Chemistry and Technology, [S. l.], v. 52, p. 113-121, 2018.

SOMBATSOMPOP, N.; CHAOCHANCHAIKUL., K. Average mixing torque, tensile and impact properties, and thermal stability of Poly(vinyl chloride)/sawdust Composites with different silane coupling agents. Journal of Applied Polymer Science, [S. l.], v. 96, n. 1, p. 213-221, 2005. DOI: 10.1002/app.21422.

SONDHEL, M. W. S. Technical fabric structures 1 . Woven fabrics. In: HORROCKS, A. R.; ANAND, S. C. (org.). Handbook of technical textiles. North and South America: Woodhead Publishing Limited, 2000.

SONG, Chuncai; HU, Haoquan; ZHU, Shengwei; WANG, Gang; CHEN, Guohua. Nonisothermal Catalytic Liquefaction of Corn Stalk in Subcritical and Supercritical Water. Energy \& Fuels, [S. l.], v. 18, n. 1, p. 90-96, 2004. DOI: 10.1021/ef0300141. Disponível em: https://pubs.acs.org/doi/10.1021/ef0300141.

SONNEMANN, Guido; GEMECHU, Eskinder Demisse; REMMEN, Arne; FRYDENDAL, Jeppe; JENSEN, Allan Astrup. Life Cycle Management: Implementing Sustainability in Business Practice. In: SONNEMANN, Guido; MARGINI, Manuele (org.). Life Cycle Management. [s.1.] : Springer, 2015. p. 7-21. DOI: 10.1007/978-94-017-7221-1_2. Disponível em: http://link.springer.com/10.1007/978-94-017-7221-1_2.

SOUZA, Dayane Rabelo de Souza. Arrangement of productive shoes in Cariri, Ceará. 2003. Universidade Federal do Ceará, [S. l.], 2003.

STAIKOS, Theodoros; HEATH, Richard; HAWORTH, Barry; RAHIMIFARD, Shahin. Endof-life management of shoes and the role of biodegradable materials. 13th CIRP International Conference on Life Cycle Engineering, [S. l.], n. March 2014, p. 497-502, 2006. Disponível em: http://www.mech.kuleuven.be/lce2006/177.pdf.

STAIKOS, Theodoros; RAHIMIFARD, Shahin. End-of-Life Management Considerations in the Footwear Industry. Global Footwear Industry and Emerging Trends, [S. l.], p. 16, 2007.

STEGMAIER, T.; MAVELY, J.; SCHNEIDER, P. High-performance and high-functional fibres and textiles. In: Textiles in sports. [s.l.] : Woodhead Publishing Limited; The Textile Institute, 2005. p. 89-119.

STUART, B. H. Infrared Spectroscopy: Fundamentals and Applications. AnTS Analytical Techniques in the Sciences. [s.1.] : John Wiley and Sons, 2004.

SUBOTNICK, Steven I.; KING, Christy; VARTIVARIAN, Mher; KLAISRI, Chatra. Evolution of Athletic Footwear. In: WERD, Matthew B.; KNIGHT, Leslie E. (org.). Athletic Footwear and Orthoses in Sports Medicine. [s.1.] : Springer, 2010. p. 3-18. DOI: 10.1007/978-0-387-76416-0. 
SUZIGAN, Wilson; FURTADO, João; GARCIA, Renato; SAMPAIO, Sergio. Local Production Systems in Brazil: mapping, typology and policy suggestions. In: 44TH CONGRESS OF THE EUROPEAN REGIONAL SCIENCE ASSOCIATION 2004, Porto, Portugal. Anais [...]. Porto, Portugal: ZBW Leibniz-Informationszentrum Wirtschaf, 2004. p. 1-18. Disponível em: http://hdl.handle.net/10419/117079.

TEIXEIRA, Isabela Tatiana; ROMANO, André Luiz; ALVEZ-FILHO, Alceu Gomes. The differentiation of products in the industry of Brazilian plastic footwear. 174 FACEF Research: Management and Development, $[S$. l. $]$, v. 17, n. 2, p. 174-184, 2014. DOI: 10.1371/journal.pone.0044657.

TEKLAY, A.; GEBEYEHU, G.; GETACHEW, T.; YAYNSHET, T.; SASTRY, T. P. Conversion of finished leather waste incorporated with plant fibers into value added consumer products - An effort to minimize solid waste in Ethiopia. Waste Management, [S. l.], v. 68, p. 45-55, 2017. DOI: 10.1016/j.wasman.2017.07.024. Disponível em: http://dx.doi.org/10.1016/j.wasman.2017.07.024.

TERCIU, O. M.; CURTU, I.; TEODORESCU-DRAGHICESCU, H. Effect of wood particle size on tensile strength in case of polymeric composites. In: 8TH INTERNATIONAL DAAAM BALTIC CONFERENCE “INDUSTRIAL ENGINEERING” 2012, Anais [...]. [s.l: s.n.]

TEXMAN. Tear de agulha 10/30. [s.d.]. Disponível em: http://texman.com.br/maquinas_comercializadas/\#. Acesso em: 5 maio. 2020.

THOMAS, Leonard C.; SCHMIDT, Shelly J. Thermal Analysis. In: NIELSEN, Suzanne S. (org.). Food Analysis. Fifth ed. Mason, Ohio, USA: Springer, 2017. p. 529-544. DOI: 10.1007/978-3-319-45776-5_30. Disponível em: http://link.springer.com/10.1007/978-3-31945776-5_30.

TOLINSKI, Michael. Choosing additives and reinforcements for sustainability. Reinforced Plastics, [S. l.], v. 61, n. 1, p. 58-60, 2017. DOI: 10.1016/j.repl.2015.10.036. Disponível em: http://dx.doi.org/10.1016/j.repl.2015.10.036.

TORRES-GINER, S.; MONTANES, N.; FENOLLAR, O.; GARCÍA-SANOGUERA, D.; BALART, R. Development and optimization of renewable vinyl plastisol/wood flour composites exposed to ultraviolet radiation. Materials and Design, [S. l.], v. 108, p. 648-658, 2016. DOI: http://dx.doi.org/10.1016/j.matdes.2016.07.037.

UM, Seong-Il. The synthesis and properties of benzoxazole fluorescent brighteners for application to polyester fibers. Dyes and Pigments, [S. l.], v. 75, n. 1, p. 185-188, 2007. DOI: 10.1016/j.dyepig.2006.04.024. Disponível
https://linkinghub.elsevier.com/retrieve/pii/S0143720806002129.

UNIFESP. Disc. Processamento de Termoplástico. [s.d.]. Disponível em: http://www.ppgecm.sites.unifesp.br/files/EMENTAS-PPGECM.pdf.

VAN RENSBURG, Melissa L.; NKOMO, S'phumelele L.; MKHIZE, Ntandoyenkosi M. Life cycle and End-of-Life management options in the footwear industry: A review. Waste Management \& Research, [S. l.], p. 0734242X2090893, 2020. DOI: 10.1177/0734242X20908938. Disponível em: http://journals.sagepub.com/doi/10.1177/0734242X20908938.

WANG, Jici. Sector, Industrial clustering in China: the case of the Wenzhou footwear. In: ZENG, Douglas Zhihua (org.). Building Engines for Growth and Competitiveness in China. 
Washington: The World Bank, 2010. p. 151-178. DOI: 10.1596/978-0-8213-8432-9.

WANG, Yafei; SU, Hong; GU, Yuanliang; SONG, Xin; ZHAO, Jinshun. Carcinogenicity of chromium and chemoprevention: A brief update. OncoTargets and Therapy, [S. l.], v. 10, p. 4065-4079, 2017. DOI: 10.2147/OTT.S139262.

WEST, Andre. Innovations in knitting at ITMA 2019 Barcelona, Spain. Journal of Textile and Apparel, Technology and Management, [S. l.], v. 11, n. 1 Special Issue, p. 1-15, 2019.

WHITE, Josh. Athletic Shoe Fit and Modifications. In: WERD, Matthew B.; KNIGHT, E. Leslie (org.). Athletic Footwear and Orthoses in Sports Medicine. [s.1.] : Springer, 2010. p. 63-68. DOI: 10.1007/978-0-387-76416-0.

WILliAMS, Anita. Footwear Assessment and Management. Podiatry management, [S. l.], v. supplement, n. October, p. 165-178, 2007. DOI: 10.1111/j.1468-2419.2012.00410.x.

WISHIN. Velo Tratorada Napa. 2020. Disponível em: https://www.wishin.com.br/velotratorado-preto. Acesso em: 29 abr. 2020.

WU, W. H.; WU, H. J.; LIU, W. H.; WANG, Y. E.; LIU, N.; YANG, X. M.; LI, Y. M.; QU, H. Q. Two Series of Inorganic Melamine Salts as Flame Retardants and Smoke Suppressants for Flexible PVC. Pol. Comp., [S. l.], p. 529-536, 2016. DOI: DOI: 10.1002/pc.23965.

XIE, Yanjun; HILL, Callum A. S.; XIAO, Zefang; MILITZ, Holger; MAI, Carsten. Silane coupling agents used for natural fiber/polymer composites: A review. Composites Part A: Applied Science and Manufacturing, [S. l.], v. 41, n. 7, p. 806-819, 2010. DOI: 10.1016/j.compositesa.2010.03.005. Disponível

em:

https://linkinghub.elsevier.com/retrieve/pii/S1359835X10000850.

YAP, B. W.; SIM, C. H. Comparisons of various types of normality tests. Journal of Statistical Computation and Simulation, $[S$. l.], v. 81, n. 12, p. 2141-2155, 2011. DOI: 10.1080/00949655.2010.520163. Disponível em: http://www.tandfonline.com/doi/abs/10.1080/00949655.2010.520163.

YICK, K. L. et. Al. Textiles and other materials for orthopaedic footwear insoles. In: LUXIMON, A. (org.). Handbook of footwear design and manufacture. [s.1.] : Woodhead Publishing, 2013.

YICK, K. L.; TSE, C. Y. Textiles and other materials for orthopaedic footwear insoles. In: Handbook of Footwear Design and Manufacture. [s.1.] : Elsevier, 2013. p. 341-371. DOI: 10.1533/9780857098795.4.341.

YICK, Kit-lun; YU, Annie; LI, Pui-ling. Insights into footwear preferences and insole design to improve thermal environment of footwear. International Journal of Fashion Design, Technology and Education, $[S . \quad l],. \quad v . \quad 12, \quad$ n. $3, \quad$ p. 325-334, 2019. DOI: 10.1080/17543266.2019.1629028.

YILDIZ, F.; PARLAR, A. G.; PARLAR, Z.; BAKKAL, M. Properties of Sound Panels Made from Recycled Footwear Treads. In: 3RD INTERNATIONAL CONFERENCE ON COMPUTATIONAL AND EXPERIMENTAL SCIENCE AND ENGINEERING 2017, Anais [...]. [s.1: s.n.] p. 936-940. DOI: 10.12693/APhysPolA.132.936.

YIN, Robert K. Estudo de caso: planejamento e métodos. 4a. ed. Porto Alegre: Bookman, 2010.

YOUNG, Hugh D.; FREEDMAN, Roger A. Livro Física II - Termodinâmica e Ondas. 12. 
ed. [s.1.] : Pearson Universidades, 2008.

ZHAI, Jing Jing. The Denim's Characteristics as Upper Material of Footwear. Advanced Materials Research, [S. l.], 2011. DOI: DOI: 10.4028/www.scientific.net/AMR.332334.1643 .

ZHANG, Chunxiao; LIN, Jiang; JIA, Xinju; PENG, Biyu. A salt-free and chromium discharge minimizing tanning technology: The novel cleaner integrated chrome tanning process. Journal of Cleaner Production, $[S . \quad$ l. $], \quad$ v. $112, \quad$ p. 1055-1063, 2016. DOI: 10.1016/j.jclepro.2015.07.155. Disponível em: http://dx.doi.org/10.1016/j.jclepro.2015.07.155.

ZHANG, Chunyu. An empirical analysis on export status quio and international competitiveness of chinese footwear products. Revista de Pielarie Incaltaminte, [S. l.], v. 18, n. 433, p. 187-194, 2018.

ZHANG, Keping; CUI, Yongtin; YAN, Wenbin. Thermal and tree-body abrasion behaviors of alkali-treated Eucalyptus fiber reinforced polyvinyl chloride composites. BioResources, [S. l.], v. 14, p. 1229-1240, 2019. DOI: DOI: 10.15376/biores.14.1.1229-1240.

ZIMMERMANN, Matheus V.; TURELLA, Tais C.; ZATTERA, Ademir J.; SANTANA, Ruth M. C. Influence of the chemical treatment of banana fiber on Polyethylene-vinyl acetate composites with and without expansion agent. Polímeros Ciência e Tecnologia, [S. l.], v. 24, n. 1, p. 58-64, 2014. DOI: 10.4322/polimeros.2013.071. Disponível em: http://www.revistapolimeros.org.br/doi/10.4322/polimeros.2013.071.

ZINGANO, Eduardo; OLIVEIRA, Júlio Cesar De. Characterization of the Brazilian footwear complex and the causes of the decline of its performance in the last decade. Estudos do Cepe, [S. l.], v. 40, p. 278-309, 2014. DOI: 10.17058/cepe.v0i40.5429.

ZULKIFLI, Siti Syazni; LOH, Wei Ping. Foot and Ankle Surgery A state-of-the-art review of foot pressure. Foot and Ankle Surgery, [S. l.], v. 26, p. 25-32, 2020. DOI: 10.1016/j.fas.2018.12.005. 


\section{APÊNDICES}

APÊNDICE A - Roteiro da Entrevista das Empresas A, B e C

\section{MATERIAL}

Tipos de produto e matérias primas utilizadas na empresa?

Tem alguma proposta sustentável?

PROCESSO DE FABRICAÇÃO

Qual o tipo de maquinário e o processo de fabricação?

\section{SEGMENTOS E TECNOLOGIA}

O produto é voltado para quais segmentos: F///M/E? Qual a \%?

A concorrência tem outros tipos de maquinários? Quais? 


\section{APÊNDICE B - Roteiro da Entrevista D}

\begin{tabular}{|c|c|}
\hline OBJETIVOS ESPECÍFICOS & QUESTÕES DE PESQUISA \\
\hline \multicolumn{2}{|l|}{ Variável I: Fabricação -Tecidos para Calçados } \\
\hline $\begin{array}{l}\text { a) Maquinário } \\
\text { Pretende-se descobrir: quais tipos de maquinários usa-se } \\
\text { para faccionar os tecidos para calçados, finuras de } \\
\text { máquinas, máquinas adquiridas recentemente. }\end{array}$ & $\begin{array}{l}\text { 1) Tipos de maquinários que facciona tecidos } \\
\text { para calçados. 2) São diferentes em relação à } \\
\text { confecção? 3) Houve compra de maquinário } \\
\text { nos últimos anos? Quando? Por quê? }\end{array}$ \\
\hline $\begin{array}{l}\text { b) Tecidos e Matérias Primas } \\
\text { Espera-se saber das matérias primas utilizadas, se tem } \\
\text { novas, como poliéster reciclado. Tipos de Tecidos mais } \\
\text { produzidos. }\end{array}$ & $\begin{array}{l}\text { 4) Atualmente, quais dos tipos de tecidos que } \\
\text { mais produz? 5) Quais são os tipos de matéria } \\
\text { primas utilizadas? 6) Tem algum tecido voltado } \\
\text { mais para a sustentabilidade? 7) Trabalham } \\
\text { com importação de tecidos cru ou pt (volume)? }\end{array}$ \\
\hline \multicolumn{2}{|l|}{ Variável II: Mercado } \\
\hline $\begin{array}{l}\text { c) Segmentos } \\
\text { Espera-se identificar quais os segmentos de calçados } \\
\text { atendidos (porcentagens) e a necessidade de mercado em } \\
\text { tecidos ou tecnologias. }\end{array}$ & $\begin{array}{l}\text { 8) Atualmente vocês vendem tecidos para quais } \\
\text { segmentos: esportivo, feminino, infantil e } \\
\text { masculino? Qual a a porcentagem de cada? } \\
\text { 9) Clientes solicitam no mercado outros tipos } \\
\text { de tecidos? 10) A concorrência tem outros tipos } \\
\text { de maquinários? Quais? 11) Há a venda de } \\
\text { tecidos para outras indústrias? Como: } \\
\text { laminadoras (volume). }\end{array}$ \\
\hline $\begin{array}{l}\text { d) Concorrência e } \\
\text { Espera-se entender qual o tamanho do mercado } \\
\text { (concorrência), se eles atendem todos os segmentos, } \\
\text { principais clientes e se clientes importam têxteis. }\end{array}$ & $\begin{array}{l}\text { 12) Quais são os principais concorrentes? Qual } \\
\text { o maior? 13) São em todos os segmentos? } \\
\text { 14) Poderia citar os maiores clientes da empresa } \\
\text { (por segmento)? } \\
\text { 15) Clientes também importam têxteis, sabe } \\
\text { algo disso? }\end{array}$ \\
\hline
\end{tabular}




\section{APÊNDICE C - Resultado da Entrevista Empresa E}

\section{Pesquisa de campo (na fábrica) feita com a Empresa E -13/11/2019 PERFIS}

Perfil da entrevistada: Mônica Debarba, idade 54, formação Técnica em Química, função: Gerente de Desenvolvimento de Produtos, atua no ramo há 36 anos, trabalha na empresa faz 19 anos.

Perfil da empresa: desde 2001. Porte: médio, possui 1 filial. Faturamento anual: R\$ 90.000.000,00. A empresa produz compostos de PVC principalmente para solado.

Tipo de processo produtivo: extrusão. Etapas e maquinários utilizados no processo produtivo: mistura, a extrusão, granulação e embalagem.

\section{PRIMEIRA PARTE - SEGMENTO DE ATUAÇÃO}

Segmento de mercado: há 2 linhas distintas de materiais em compostos de PVC no calçado: o compacto (exemplo: sandália Melissa $\left.{ }^{\circledR}\right)$ e o expandido microcelular. Há também por expansão química, mas está praticamente em desuso.

Outros produtos: Alguns produtos no mercado de perfis - para mangueiras, móveis, calçados e laminados calandrados (calçados e bolsas). Processo do perfil: ele é contínuo e o produto tem formato de "espaguete", eles são muito utilizados em calçados e bolsas, (viras e faxetes) e, também, nos cintos.

Como é a utilização do produto em seus clientes? A empresa fornece o composto para transformação, ele é granulado e vendido em embalagens de $25 \mathrm{~kg}$ e, eventualmente em bigbag. Os clientes compram e transformam. Atualmente, é mais comum que os clientes sejam as empresas de calçados, pois tornou-se uma tendência na verticalização dos processos, porque assim se tem um controle maior na qualidade. Pois quando se terceiriza a produção de solas, pode ter consequências no processo do controle da qualidade do calçadista. Essa realidade vem mudando faz alguns anos e o mercado de terceirização de injetados tem diminuído muito.

Normalmente, as novas empresas começam a comprar a sola pronta, até quando o volume justifica comprar as máquinas para a injeção. A maior parte das empresas grandes fazem o seu solado, que muitas vezes não estão na mesma planta de sua produção, mas em unidades separadas. Assim, todos os controles dos processos são mais efetivos.

Com isso, os calçadistas viraram nossos maiores clientes, não os "injetadores" (intermediários), nomeados desta forma no mercado. Essa mudança para a PVC Sul foi boa, porque facilita na fidelização com o cliente, enquanto, muitas vezes, as negociações com os intermediários eram focadas mais em preço.

\section{SEGUNDA PARTE - SUSTENTABILIDADE}

Primeiro contato da empresa sobre a Sustentabilidade: Já é trabalhada na empresa há um tempo, o que é recente, é a incorporação de fibras vegetais no processo.

Uma das matérias primas de origem vegetal são os plastificantes, uma solução para a substituição dos produtos de origem do petróleo. Eles são utilizados pela empresa já faz um tempo e a opção de escolha inicialmente foi demandada pela dificuldade de compra da matéria prima, uma vez que grande parte era importada.

Outras vertentes surgiram nos últimos anos, como os óleos que vieram para substituir os ftalatos, após limitação de uso pelo REACH (União Européia) e outros países e empresas. Então, quando começaram essas implicações, os fabricantes começaram a procurar soluções para transformar os ftalatos em outro produto. Assim, a busca era para modificar a molécula para não ser mais um ftalato, e aí, surgiram esses óleos. Depois, quando surgiu a questão da sustentabilidade para a cadeia dos plásticos, pode-se aliar também esses óleos nesta nova vertente.

Participação do selo "Origem Sustentável": Há o interesse, mas como o selo não abrange somente o produto, inclui mudanças em toda a gestão da empresa, então, ele ainda está em avaliação pela diretoria. 


\section{SEGUNDA PARTE - SUSTENTABILIDADE NO PRODUTO}

Sustentabilidade ambiental tem afetado o desenvolvimento de produto? Por exemplo, a questão das fontes naturais e biodegradáveis, isso tem afetado a PVC Sul?

A empresa trata a questão da energia há bastante tempo por exemplo.

A questão de controle de resíduos por sorte o PVC é 100\% reciclável, então a gente não tem efluentes, não tem resíduos.

O polímero do PVC é de origem do petróleo ainda, existe conhecimento para produzir a partir do álcool etílico, mas ainda não é viável economicamente para quem fabrica a resina. A Braskem faz o polietileno verde e eles ainda não sinalizaram sobre quando será a introdução do PVC a partir do álcool, segundo eles, há a influência também do custo superior ao polietileno.

A vantagem do PVC, em relação aos outros polímeros que são de origem do petróleo, porque ele é 47\% do petróleo e 53\% do sal marinho. Então uma parte do PVC é de origem natural. Hoje em dia, a gente consegue materiais com até $80 \%$ de compostos de origem renovável.

O óleo de soja epoxidado já existe há muitos anos. O óleo de soja epoxidado tem a função de co-estabilizante, embora exista casos de empresas que utilizem ele como plastificante, nós não, porque o risco é muito grande de dar problema no processo. Porque o composto de PVC para calçado vai ser colado, pintado, recebe transfer, isto é, diversos tipos de acabamentos são feitos e não podem gerar problema posteriormente. Então, no momento que produz, injeta e faz esses processos pode não se perceber nada, mas a longo prazo pode acontecer algum defeito. Não queremos correr esse risco e ainda pode ter consequências em indenizações, então a gente prefere trabalhar com a prevenção.

Hoje em dia, uma tecnologia que apareceu há poucos anos é a esterificação do óleo de soja epoxidado, houve muita evolução neste tipo de matéria prima e este produto tem ótimas performances como plastificantes primários. Utiliza-se também o óleo epoxidado conjuntamente, mas tem um limite, mas como os dois são da mesma origem, há essa possibilidade. Uma consequência que isso trouxe é a questão do preço, porque fez com se nivelasse o mercado em termos de custo. Fazem uns 5 anos que começou aumentar os volumes desse tipo de plastificante.

Outra matéria prima de origem natural é o carbonato de cálcio, porém eventualmente se utiliza. As fibras vegetais a gente está trabalhando mais recentemente, um dos conceitos com elas é estético, embora tenha muito forte a questão do lado sustentável e ainda porque muitas delas são resíduos. Ou também por trazerem vantagens, porque o plantio oferece benefícios para a natureza, no sequestro de carbono e tudo mais.

Os produtos com fibra vegetal estão tendo cada vez mais procura e o interesse está crescendo no mercado. Nós lançamos estes materiais com a fibra este ano (2019) na Fimec, mas começamos os testes no final do ano passado (2018), já tínhamos uma linha de produto com madeira e com cortiça, então já tínhamos uma certa referência e uma noção de como funcionam essas fibras. Elas têm alguns problemas de umidade, de variação dependendo da fonte e tamanho das fibras, mas a gente passou isso para os fornecedores e ele nos adequou para nossa necessidade e homologamos um padrão.

A gente lançou na Fimec e depois no Inspiramais, em julho, e agora que está refletindo. Mas sabe-se que é só o começo e que é uma tendência muito forte e duradoura. Tem crescido bastante as solicitações principalmente com fibra de bambu, cana e, um pouco menos na de coco, além da cortiça e da madeira. A gente cogitou a fazer com a fibra de arroz, mas ela é muito abrasiva, não é interessante porque danifica muito a extrusora e, a rosca e o cilindro são muito caros, aí não teve motivos para trabalhar com ela. Além disso, também poderia trazer algum desgaste para o transformador no processo dele e, também já existe um mercado da fibra de arroz que faz bandejas, utilidades domésticas, como exemplos.

O eco-design também tem sido uma forma de nascer um produto reduzindo o impacto ambiental. Normalmente relaciona-se quando diminui etapas produtivas, faz economia de energia, ou utilizar novas tecnologias (impressão 3D). Tem alguma ação nesse sentido na empresa?

Ainda está longe, o que se vê são lançamentos pontuais por enquanto, de empresas de médio e grande porque que lançaram um ou 2 produtos em $100 \%$ de origem renovável ou até biodegradável. 
A questão de impressão 3D ainda não é muito comum, apesar que é um caminho que deve acontecer, mas deve demorar ainda eque seria um nível superior na personalização. Talvez chegue a um momento que quando entrar em uma loja, poderá sair com um calçado montado, como seria a "fábrica do futuro".

Atualmente, essa personalização ainda está longe, porque ainda se depende da escala de produção dos calçados. Mas, cada vez mais se vê esses lançamentos, uma grande empresa vai lançar no Inspiramais um produto que é totalmente biodegradável, a sola, o cabedal, a palmilha, o cadarço; cada empresa envolvida desenvolveu um produto e eles fizeram um calçado.

Outro caminho para a sustentabilidade ambiental é gestão do destino final. Existem ações na empresa? Há 4 tipos principais: reuso, reciclagem, geração de energia e descarte. Poderia apontar se a empresa aplica algum desses 4 tipos?

O que vai existir é o ciclo reverso.

Atualmente, se recicla muito mais metal do que plástico, a reciclagem do metal chega a $80 \%$ e do plástico, uma quantidade bem inferior em $9 \%$ ou $10 \%$, quando muito. Então, precisa melhorar muito isso ainda.

O PVC é $100 \%$ reciclável.

\section{E o problema com os resíduos do cloro?}

O problema que existe é o risco de incineração, o PVC não deve ser incinerado, porque aí ele gera dioxinas, que são extremamente tóxicas e até cancerígenas. Por isso que quando deu os atentados do 11 de setembro nos Estados Unidos, tiveram tantos casos posteriores de intoxicações, de doenças graves em função da fumaça, da queima do PVC. Então, para algumas aplicações, ele é super modificado para ele não se tornar inflamável. O PVC não é inflamável naturalmente, mas ele precisa ser aditivado para aumentar a resistência, para não propagar a chama, mas em um incêndio onde as tubulações de água são de PVC, então, onde houver carbonização, isso é um problema para a natureza.

Então é isso que não se quer, por isso que o correto descarte é tão importante quanto a sustentabilidade. Todas essas campanhas contra os plásticos em geral, a ideia não seria banir, mas claro quem trabalha com o plástico sempre vai querer defender. Apesar que há uma atenção aos volumes, mas para substituir o plástico teria elevação de custo dos produtos e, hoje, não se consegue imaginar a viabilidade disso.

E no calçado, sobre ações existentes no após o uso. Tem alguma ação por parte da empresa? Ou conhece alguma ação no Brasil?

Não respondeu

Teria uma sugestão do que poderia ser feito na melhoria da sustentabilidade ambiental do setor calçadista brasileiro?

Não respondeu 


\title{
APÊNDICE D - Resultado Entrevista sra. Linda Pienis (IBB)
}

\author{
Pesquisa de campo feita no escritório em Novo Hamburgo, RS - 13/11/2019 \\ PERFIS
}

Perfil da entrevistada: função: Coordenação de Projetos

9 anos de experiência no cargo atual.

\section{Caracterização da instituição:}

Nome: Instituto by Brazil

Fundação: maio de 2006, Novo Hamburgo-RS

Porte: microempresa

Tipo: particular

Número de colaboradores: 6

Faturamento (2018) R \$2.000.000,000

\section{i. Selo Origem Sustentável}

Quando foi criado o Selo Origem Sustentável?

2013

Por que a instituição desenvolveu o selo? Como esta decisão foi tomada e quem estava envolvido no processo?

O assunto da Sustentabilidade começou a ser trabalhado em 2010 e, na época, era um assunto bem pioneiro, não existia nada formatado, principalmente no setor de calçados e componentes.

Então foi contratada a prof. Tereza Carvalho da USP, ela já tinha um trabalho desenvolvido em Sustentabilidade na área de eletrônicos, a partir do departamento em que trabalha, o LASSU. Houve o contato com o MIT, por sua intermediação, na qual auxiliou bastante na estruturação do programa. Um grupo do MIT veio para o Brasil e se surpreenderam com a organização daqui; quando começaram a visitar as empresas no Brasil, pois eles achavam que aqui havia esgoto à céu aberto ou trabalho infantil, mas quando eles viram a estrutura das empresas e a rigidez da lei trabalhista, que anteriormente era mais rígida ainda, eles ficaram bem surpresos.

Em 2017, estava previsto uma revisão, em 4 anos vimos que as empresas já estavam mais maduras, elas mesmos já vinham comentando que não era uma certificação com muita credibilidade, pela questão de ter muitos participantes com o selo, mas muitos deles não passavam por auditoria.

Houve a contração de um novo consultor, que já trabalhava nessa área de sustentabilidade, que desenvolveu o programa do couro.

O selo está em processo para torná-lo público, para ele ser creditado pelo INMETRO, motivo pelo qual, daria mais credibilidade.

\footnotetext{
Houve outros selos que serviram de modelo? Se sim, quais?

A prof. Tereza Carvalho encontrou uma certificação de vestuário, dentro do segmento esportivo; hoje ela já tem uma associação que cuida da parte de sustentabilidade, que instituiu uma forma de medir o quanto as empresas estão com a sustentabilidade incorporada, tem um índice com os dados que as empresas têm que preencher com fornecedores.

Depois, outros países já estavam trabalhando nessa área, como Portugal. A busca também ocorreu em outros setores que já tinha algo mais estruturado, setor da construção e setor de alimentos.

Quais são os pilares do selo?

No início, em 2013, eram 4 pilares: o econômico, o social, o ambiental e o cultural. Esses 3 primeiros já eram muito conhecidos, já existia muita coisa no mundo, mas a gente quis incluir mais um, o cultural, para dar assim para as empresas uma importância a noção da preservação da cultura. No Brasil, a gente tem várias culturas que a gente tem artesanato, modo de fazer as coisas e a gente não queria perder isso. Se não, vira tudo calçado igual, como se não tem uma nacionalidade o calçado e a China tomaram conta e tomou tudo. Então, para preservar isso, inseriu-se o cultural.

Depois, na atualização em 2017, não chama mais pilar, chama dimensão, mas mantiveram os quatro e, incluímos, a gestão da sustentabilidade permeando todas elas.

No ambiental, o que foi incluso de novo foi a questão das substâncias tóxicas e o foco na melhoria gestão de resíduos. Houve a necessidade de dar ênfase para as empresas na dimensão econômica, para que eles vissem ganhos no programa. Se eles não conseguissem vislumbrar que iam ter um lucro, que iam ter um ganho financeiro, eles não entrariam.
} 
Eu sempre acompanho as auditorias, as empresas até faziam economias, mas elas não tinham aquilo sistematizado. Por exemplo, a conta de luz foi uma surpresa, ver o quanto foi gasto no ano e quanto coisa poderia fazer para diminuir aquela conta.

A gente trabalhou aqui em projetos de eficiência energética, para levar para empresas novidades e ideias para diminuir o gasto. A questão da água também, tem empresas que quase não usam água, mas outras, como os têxteis usam grande volume.

\section{Há algum pilar central que impulsionou o desenvolvimento do selo?}

Não.

Como funciona a implantação nas empresas?

A gente faz assim, tem todo um passo a passo. A empresa entra em contato. O selo é uma realização da Assintecal e da Abicalçados, que são as duas instituições, a Assintecal como componente e a Abicalçados o calçado pronto e, o IBB faz a gestão. Então, quando a empresa entra em contato, se for calçado vai entrar com a Abicalçados, se for componente vai entrar com a Assintecal e eles encaminham para nós.

A empresa assina um termo de compromisso, a gente entrega o manual, faz o treinamento. Esse treinamento foi o quinto, o treinamento serve para ensinar a metodologia, porque só o manual a gente percebe que ele não consegue absorver, mesmo participando do treinamento, eles pedem uma consultoria bem pontual na empresa para poder auxiliar.

Então, as empresas participam do treinamento, ganham o manual e começam a implementar os indicadores. Quando ele se sentir pronto, ele chama a auditoria, preenche o formulário e manda para que a empresa que vai fazer a auditoria. Hoje, as que mais atendem aqui o setor é o Senai e a SGS.

Como são medidos os critérios para a obtenção do selo?

Dentro das 5 dimensões, há 64 critérios com um total de 124 indicadores. Há 32 indicadores obrigatórios, isso a gente fez, esses obrigatórios foram ampliados para que a gente minimizasse o risco mais possível, para não acontecer de uma empresa se certificar e não ter o básico.

Como são divididos os patamares em: bronze, prata, ouro e diamante?

Para as empresas atingirem esses níveis de certificação, elas precisam atingir, no mínimo, os 32 indicadores obrigatórios, mais a quantidade de cada nível: Bronze (50\%), Prata (75\%), Ouro (95\%) e Diamante (100\%).

Houve uma modificação recente na sua estrutura, poderia explicar? E, por que ocorreu?

A revisão já estava prevista, para 2017. Houve uma reformulação, a gestão da sustentabilidade passou a estar junto com as 4 dimensões, dentro da estratégia de negócio da empresa e era necessário ter pessoas de todos os setores coordenando esse trabalho, pois na versão anterior, houve casos de empresas, que só 2 pessoas estavam a par dos assuntos do selo.

Poderia me dizer a \% de adoção do selo? Por categoria: componentes, indústria de calçados etc.

Na versão anterior do selo, totalizo com a adesão de 150 empresas. No final de 2019, havia 5 empresas certificadas pela nova versão e mais 45 em processo de aquisição.

Qual o custo para a obtenção do selo?

O custo é assim, o termo de compromisso a empresa assina e ela paga $\mathrm{R} \$ 600,00$ para participar do treinamento e ganhar o manual, aí depois ela se prepara e chama a auditoria. A auditoria é entre R \$1.200,00 e 1.500,00 por dia, pode levar cerca de 3 ou 4 dias para a empresa ser auditada tudo.

\section{ii. Reação do Mercado}

Qual foi a data da primeira implantação do selo Origem Sustentável?

Janeiro de 2013.

O que as empresas reportam de benefícios após o processo de obtenção do selo?

As empresas demonstram o ganho do ponto de vista dos controles, antigamente, apenas o setor de Segurança do Trabalho fazia o trabalho. Com a nova versão, o RH, o econômico, o financeiro trabalham juntos, então, essa sistematização de controle começou a demonstrar os ganhos.

E, as dificuldades também?

As dificuldades ainda hoje é a falta de prioridade das empresas. A pergunta que eles fazem: -Mas, o que eu vou ganhar com isso? -Mas, eu vou ter que ter gente aqui trabalhando só nisso agora, vou ter que ter um custo interno para fazer isso. -Meu cliente não quer pagar mais, meu cliente não está pedindo.

Há alguma relação entre a exportação de calçados/componentes e a adoção do selo?

Sobre a exportação hoje a gente considera que as empresas quando falam, é aquela questão do diferencial. Atualmente, as empresas que exportam calçado estão sofrendo bastante com a questão da substância restrita. Existe um programa sendo criado, porque teste já é obrigatório, mesmo componente, ele não sai do Brasil se ele não cumprir a cartilha que o cliente traz, dependendo do país que o compra, também tem algumas regras específicas.

Na sua opinião, a criação do selo Origem sustentável influenciou na expansão no foco da Sustentabilidade no setor? Antes já era falado amplamente? 
Sim, aumentou. Agora, você pode ver pelo evento que a gente vai fazer hoje, ninguém esperava tanta gente. Quem é que a gente trouxe para falar, ninguém é tão novo no mercado. O dono da empresa da Arezzo é uma pessoa pública, mas ele não chamaria tanta gente para falar de sustentabilidade, se não fosse...

Também percebe que houve o surgimento de empresas com foco em produto ou serviço sustentável? Dê exemplos.

Nos componentes também. Tecidos reciclados, tecidos com materiais orgânicos estão sendo valorizados, tingimentos naturais, muita coisa feita com resíduo no solado, mais reciclado. Materiais novos, muita coisa vinda da natureza; e o plástico, vindo do amido, de mandioca, é um campo que está crescendo muito.

A gente tinha muita demanda para isso, nós criamos um guia virtual que a gente tem no sistema e, esse guia traz as principais empresas que trabalham nessa área de produto diferenciado.

O selo inclui o quesito de gestão de resíduos sólidos? (x) sim () não

Caso afirmativo, quais as iniciativas aplicadas? Poderia citar exemplos de empresas de componentes e de calçados.

$\mathrm{Na}$ reformulação do selo, inseriu a questão da gestão de resíduos bem feita, com a inclusão de conceitos de economia circular, para as empresas se derem conta que nada é lixo, tudo pode ser reaproveitado.

O calçado ainda é um problema, né? Porque alguns já tentaram fazer a logística reversa, pro calçado não fosse para aterro e coisas assim. Mas, o calçado no Brasil, acho que no mundo todo é assim, ele passa de mão em mão até perder valor, ninguém bota o tênis fora, a não ser que hidrolise e vire pó. O que faz é a doação para alguém, ou se dá para uma pessoa mais pobre de repente, que ainda vai usar mesmo ele estando "manchadinho" ou alguma coisa assim. Então ele demora um pouco para ele ir pro lixo. E no fato do último que usa, ele não tem ainda, ele não tem o interesse de pegar e levar paro fornecedor. 


\section{APÊNDICE E - Resultado Entrevista Cipatex}

\section{Pesquisa de campo (na fábrica) feita com a empresa Cipatex -10/12/2019 PERFIS}

Perfil da entrevistada: Sara Tatiane Trevisani, idade 41 anos, formação Gestora ambiental e Pós Eng. Ambiental e Saneamento, função: Coordenadora de Sustentabilidade, atua na função há 15 anos, trabalha na empresa fazem 18 anos.

Perfil da empresa: Cipatex, desde 1963. Porte: grande, possui 6 unidades. Faturamento anual: R\$ 700.000.000,00, número de funcionários: 1500.

Tipo de produto: laminado de PVC (nesta unidade). Tipo de processo produtivo: espalmagem.

\section{PRIMEIRA PARTE - SEGMENTO DE ATUAÇÃO}

Segmento de mercado: setor calçadista (o fabricante de calçado); moveleiro; piscina - Cipavinil (atende ao público direto e lojista); ramo hospitalar com tratamento bactericida (colchonete, cortina, cadeiras dos médicos); náutico com agente inibidor de fungos devido ao contato com água; construções (barracões de PVC) que utilizam proteção UV ou anti-chamas (PVC não propaga a chama, ele derrete, o aditivo ajuda a controlar o fogo se tiver alguma fiação embaixo por exemplo).

Outros produtos: Cipageo - reservatório que usa geomembrana na fabricação de lítio; mercado de brindes (capa de agenda, embalagens).

Matérias primas: Principal matéria prima é a resina de PVC, tem resina de suspensão e emulsão. A resina de emulsão é usada para tudo que precisa de um toque mais macio, como exemplo o material aplicado no moveleiro ou o calçadista. Agora, a resina de suspensão é destinada para produtos mais rígidos. O plastificante é free ftalato, ele não tem DOP que foi banido da fábrica, há algumas situações a que é usado o DINP, ele tem ftalato, mas está dentro da cadeia, o que o faz ser legalizado. Todos os tipos de pigmento não utilizam metal pesado, que foram banidos há mais de 10 anos na empresa.

\section{SEGUNDA PARTE - SUSTENTABILIDADE}

Primeiro contato da empresa sobre a Sustentabilidade: há o planejamento da sustentabilidade desde sempre, como exemplo, há um funcionário que sempre trabalhou com isso e está aqui há 55 anos, desde o início da Cipatex. Ele sempre trabalhou pensando no que se pode reutilizar internamente.

Em 2002, tornou-se um setor, o de Meio Ambiente. Antes, fazia parte do processo. Atualmente o setor tem 20 pessoas, com colaboradores em várias áreas da empresa como: no setor de resíduos, na prensa, na separação e no próprio setor. Na verdade, todo mundo faz parte, porque os setores já selecionam os materiais para mandar para a prensa e, depois, só enfarda e manda para a central. A central busca o melhor caminho.

Há ainda a visita de todos os clientes de resíduo para verificar o que eles têm como forma de contensão e como trabalham, para verificar se não têm mão de obra escrava por exemplo.

Outras vertentes surgiram nos últimos anos, como os óleos que vieram para substituir os ftalatos, uma reação após limitação de uso pelo REACH (União Européia) e outros países e empresas. Quando foram feitas essas restrições, os fabricantes começaram a procurar soluções para transformar os ftalatos, assim, a busca era para modificar a molécula e, com isso, surgiram esses óleos. Depois, quando apareceu a questão da sustentabilidade para a cadeia dos plásticos, pode-se aliar também esses óleos nesta nova vertente.

Selos da empresa: Origem sustentável e a empresa está em andamento para o desenvolvimento de um selo interno. Pois o processo está certificado pelo selo “Origem Sustentável”, mas a empresa não pode utilizá-lo para outros segmentos e, então decidiu-se montar um selo interno, como a Toyota e Honda também já têm. Houve o foco nos 17 objetivos do milênio, mas iniciou em um trabalho de "formiguinha", que precisa alimentar todo o sistema e, isso faz mais ou menos um mês (novembro de 2019), a diretoria também está aderindo à ideia deste projeto.

Participação do selo "Origem Sustentável": O selo da Cipatex é o ouro. 
Na realidade, como há uma parceria com a Assintecal e a empresa, no início do desenvolvimento, foi feito um piloto aqui, que por consequência alterou algumas perguntas do manual, como exemplo, ao separar a parte do laboratório e do processo industrial. Isso ocorreu, pois a prof. Cristina (USP), sob consultoria externa da Assintecal veio na empresa junto com o MIT para conhecer o processo.

A empresa foi a primeira a aderir o selo e, ainda, desenvolveu junto. No início, falava-se que não ia conseguir, mas quando o resultado chegou, apesar do selo branco ser o primeiro estágio, verificou-se que se adequava ao selo ouro. E aí, foi nos perguntado se iria aderir ao selo ouro. Só não foi até o nível diamante, porque não tinha a ISO 14001.

Uma questão importante foi que não era o problema ao obter o selo ouro, mas conseguir mantê-lo. Porque a manutenção de um sistema é muito cara, é muito difícil porque você tem que manter as pessoas empenhadas e com foco e, ainda a energia que gasta com elas é muito maior para permanecer do que conquistar.

O selo influenciou à relação da empresa com os fornecedores? Eles tiveram que se readequar de alguma maneira? Quando iniciou a troca de pigmento, com a substituição do metal pesado, foram envolvidos todos os fornecedores, há cerca de uns 15 anos. Quando foi falado que não seria mais comprado nenhum tipo de produto dentro da lista restritiva da tabela REACH (europeia), precisou-se entrar em contato com todos os fornecedores.

Dentre as dimensões do selo em: econômico, ambiental, social e cultural. Entre eles, tem algum que seja mais importante para a empresa e por quê? Ou teve algum que não era tão evidenciado antes do selo? Todos são importantes, mas o que precisou de muito trabalho foi a dimensão cultural, principalmente da parte do patrimonial, sabia que se fazia muita coisa, mas não tinha evidência.

A empresa já fazia muitos eventos externos, com contribuição em escolas também, mas a questão cultural interna não estava documentada. Sabe aquele museu interno? Não tinha. A parte de manter o patrimônio da empresa, as memórias, precisaram ser evidenciados através de busca de relatos, também foi feito um documentário.

Para adquirir o selo, quais foram as principais mudanças internas para ajustar aos critérios do selo? Poderia dar exemplos. Não houve uma mudança, teve que incorporar informações ao trabalho do funcionário, mas era mais uma continuidade do que ele já fazia. Como exemplo, o trabalho de 5S passaria a ser contínuo, não apenas aquele dia de limpeza. É manter o setor limpo, o que pressupõe em não sujar. Então, é manter essa cultura para a manutenção deste sistema.

Igual a matéria prima, a equipe de desenvolvimento está sempre procurando uma que deve ser compatível e aprimorar o produto ou também para ser mais sustentável.

Outro exemplo, é o produto Vegan. Também teve o lançamento do Ecologic para atingir o mercado, neste produto não é usado o papel no processo, assim, estaria reduzindo matéria prima que, mesmo sendo reciclável, fez reduzir o seu consumo.

Com isso, abriu a mente do pessoal para buscar projetos novos, projetos de redução de energia e água, então os funcionários trazem soluções como: redução do copo plástico, papel toalha. Porque na correria do dia a dia, muitas vezes não se consegue enxergar, mas eles que estão ali no setor, conseguem trazer ideias reais. Na limpeza, houve economia do tecido de TNT.

Pontos positivos: Houve a economia de água em 50\%. O layout da fábrica melhorou no aspecto visual, pela limpeza e organização, além das pessoas estarem mais conscientes para evitar a sujar o ambiente de trabalho e, como consequência, perde-se menos energia limpando.

Houve a redução de resíduo gerado

Quando se introduziu os temas do o selo na fábrica, os funcionários absorveram tão bem, que eles mesmos começaram a fazer projetos internos e trazerem a melhoria para o setor de Meio Ambiente. Então, eles trouxeram ideias de inovação na parte sustentável e, inclusive chegam todos os dias algumas propostas diferentes e isso é gratificante.

Dificuldades: No começo, houve dificuldade com as pessoas para transmitirem os dados, porque a gestão para o processo do selo envolve a fábrica toda. Assim, é necessário pedir dados ao financeiro RH, comercial e industrial. Na produção tem a questão do segredo industrial, por isso houve dificuldade ao mostrar para as pessoas que não 
se queria ter o domínio do assunto, apenas conseguir a informação para o selo, uma vez a empresa tem alguns processos que ninguém faz. $\mathrm{O}$ que precisou foi o registro, o comprovante das ações. E a diretoria ajudou e auxiliou para intermediar essa questão da informação.

Pontos para melhoria: Há algumas pessoas, principalmente as mais antigas em funções de coordenação que ainda apresentam algumas resistências às mudanças. Assim, mostra que a empresa precisa ainda de uma mudança cultural.

Houve alguma vantagem da obtenção do selo em relação à exportação dos seus produtos? Sim, na verdade, só há a inserção no mercado externo se tiver um selo sustentável ou todo um processo sustentável. Também teve a aquisição de alguns mercados, como os americanos e europeus. Não se sabe exatamente se foi efeito direto do selo, mas pode ter sido uma consequência, porque as pessoas já tinham mais informação e sabiam o que falar lá fora. Porque antes, não era nada divulgado.

Nova versão (2019) do Programa "Origem Sustentável": A data limite para obtenção do selo é até julho (2020), a ideia é juntar essa necessidade com o selo interno, pois os dados são os mesmos, os equipamentos e matérias primas também. O selo da Assintecal, devido à parceria haverá a continuidade e renovação.

\section{SEGUNDA PARTE - GESTÃO DO DESTINO}

Outro caminho para a sustentabilidade ambiental é gestão do destino. Existem ações na empresa? Há 4 tipos principais: reuso, reciclagem, geração de energia e descarte. Poderia apontar se a empresa aplica algum desses 4 tipos? Há a central de resíduos, onde internamente já faz a separação de resíduos e chega a ter a variedade de mais de 20 tipos de materiais que são separados. Vende-se para clientes que fazem tanto a reciclagem quanto o reuso.

Para geração de energia, já foi iniciado um trabalho, mas ainda não está maduro para isso, o que representa os $0,1 \%$, que hoje é pago para incineração.

No processo de pirólise consegue-se separar os materiais líquidos, dos em pó e ainda gerar energia (gasoso). Houve um trabalho junto com uma universidade (Unicamp), mas o investimento era muito alto para a pesquisa, houve uma pausa porque foi o ano de 2019 foi complicado, mas o projeto ainda está em stand by e pretende-se retornálo.

O outro trabalho é a engenharia reversa que é feita internamente, que uma parte do resíduo é reutilizada internamente como matéria prima. Quem contribui muito para esse processo é o Fernando (mestre, com 25 anos de empresa), o Mitsu (mestre em polímero) e a Andreza (química), eles que mais apoiam e, depois dos testes que se dá o andamento para o processo fabril. Então, há um pessoal muito capacitado internamente.

Outra possibilidade são as parcerias com as universidades, inclusive na engenharia reversa para transformar em outro produto, como exemplo, a aplicação em acabamentos para tubetes. Mas, ainda está sendo desenhado e pesquisado para entrar em contato com elas.

E no calçado, sobre ações existentes no após o uso. Tem alguma ação por parte da empresa? Ou conhece alguma ação no Brasil? Há notícias de algumas empresas e Universidades fazendo pesquisas, porque o calçado tem vários componentes, tem o cadarço, a sola, a palmilha, a espuma, o salto as vezes é de madeira, plástico ou sisal. Depois que destrincha ele, teria que mandar para mercados diferentes de reciclagem, não consegue fazer um uso só.

Como seria a logística reversa de um calçado pronto? Primeiro, é preciso uma área, com equipamentos próprios para isso e ainda pessoas especializadas para distinguir os componentes. Você tem um ilhós do tênis que é um metal, tem tecido, laminado de pvc, espuma, tem um monte de coisa dentro de um calçado, então precisa buscar várias pessoas com vários entendimentos para encontrar uma solução. Não se conhece empresa no Brasil que faça a logística reversa ainda.

Teria uma sugestão do que poderia ser feito na melhoria da sustentabilidade ambiental do setor calçadista brasileiro?

Existem algumas, quando houve o curso do selo, o treinamento dessa nova versão do selo, eles falaram muito e associaram bastante a produção de laminado com a produção de couro. E, na verdade, são bem diferentes, bem 
distintas, porque a produção de couro tem o impacto ambiental e se gera efluente, com a presença o cromo e outros metais pesados.

Normalmente opta-se por não falar mal do couro, porque isso é recíproco. Mas, essa desassociação precisa existir, pois enquanto aqui há circuito fechado de água que a água circula, não lança efluente a lugar nenhum. O esgoto é efluente doméstico e é tratado totalmente pela concessionária. A água utilizada internamente, tanto a potável, e a do processo é reinserida e tratada internamente, o resíduo gerado é só bacteriológico, que também é tratado e descartado corretamente.

Em termos de resíduos, é feito $100 \%$ o descarte correto, se não é vendido. Então, há todo um controle ambiental na área de trabalho dos funcionários, isso já justifica para desassociar do couro, porque foi observado no novo selo muita proximidade, em questões relacionadas ao grande impacto, tipos de poluentes e contaminação. Talvez seja porque houve contato com a cadeia do couro para desenvolver o selo e faltou consultar o setor todo, no dia a dia e entender as dificuldades.

Perfil da entrevistada: Fernando Brandão, idade 57 anos, formação Bach. Em Química, função: Químico, atua na função há 24 anos, trabalha na empresa fazem 24 anos.

\section{SUSTENTABILIDADE NO PRODUTO}

\section{A questão da sustentabilidade ambiental tem afetado o desenvolvimento de produtos? Poderia dar algum exemplo.}

O que está sendo repensado agora torna PVC importante nessa questão, porque boa parte do peso é composto por sal. O sal marinho é uma fonte não carbono-fóssil e quase renovável. Isso contribui a favor do PVC, porque há mais quantidade de sal do que carbono fóssil por kilo, diferentemente do polietileno ou poliuretano, que tem mais quantidade em resina.

A parte do plastificante vegetal no Brasil está bem desenvolvida. Na empresa utiliza-o em algumas aplicações, que é uma tecnologia nova, em vez de usar plastificante do petróleo, DOSH ou DNP, é usado os plastificantes vegetais. Mas, ainda é um aprendizado, embora esteja ampliando a aplicação.

Como o plastificante vegetal não é como a indústria petrolífera, que tem estrutura definida, o vegetal depende da safra. Mesmo o Brasil já tendo histórico de uso do Drapex e óleo de soja. Alguns fabricantes pegaram esse óleo de soja epoxidado e fizeram algumas esterificações (reações) e deixaram o plastificante melhor, agora se pode aumentar a quantidade. Só que ainda é um produto que tem menos de 10 anos no mercado, então usa-se com cautela.

O Brasil e' muito forte nisso, porque além de ser sustentável há a vantagem de custo, mesmo que seja pouca a diferença. O único problema agora (dezembro, 2019), foi a demanda de soja da China, aí o mercado preferiu exportar a soja ou óleo de soja ao invés de fazer o plastificante e, com isso, o preço acabou subindo.

Na pesquisa sobre como as mudanças ambientais afetaram os produtos, identifica-se que no mundo, uma das tendências é através da incorporação de aditivos de fontes naturais ou biodegradáveis. Já tem alguma linha específica? A linha mais voltada para essa área é a Vinyltech, que o apelo é a durabilidade. O material também possui outras propriedades como maleabilidade e conforto térmico e, como resultado, com esse laminado consegue-se fazer um calçado mais bonito. A empresa pensa assim, você faz um produto mais bonito e com mais qualidade, então o diminui descarte.

E agora começando a olhar muito aqueles 17 desafios da ONU, então quando você tem um produto como pvc, que você consegue atender uma parcela da população menos afortunada. Assim, um produto de qualidade legal com durabilidade, você está fazendo uma parte social importante ao oferecer um produto digno e com preço competitivo.

A durabilidade do não descarte, o consumo fica mais consciente, vai agregar o custo, isso são equações que não vamos conseguir resolver.

Produto vegano. A história começou com o Rafael (do desenvolvimento, que estava no laboratório), ele fez um cabedal com um tecido especial com uma formulação macia diferenciada, desenvolveu um produto e não se preocupou com o preço. Quando foi montado o calçado, ele ficou muito bacana, "encheu o calcado, quando não 
fica um calçado murcho e parece que é um de couro". Assim, foi adotado como vegano, porque está parecido com couro e podia dedicar ao seguimento. O segundo passo foi a pergunta: o que é vegano? Ou, se o plástico é vegano? Foi feita uma pesquisa com os fornecedores, através de um questionário para declarar se tinha alguma matéria prima de origem animal. Foi achado um item que era animal, aí foi substituído. Era um aditivo ácido orgânico da cadeia do boi, mas tinha uma opção vegetal, fez-se o trabalho com o fornecedor, testou-se e ficou bom. Aí se pode chamar de vegano. Total de venda do produto: cerca de 5.000m, já são uns 50mil calçados (2019).

O eco-design também tem sido uma metodologia que influencia no impacto ambiental. Normalmente relaciona-se à diminuição das etapas produtivas, economia de energia, ou aplicação de novas tecnologias (impressão 3D). Tem alguma ação nesse sentido na sua empresa? A parte de reduzir processo não tem muito como, pois, ele já é bastante maduro. Ainda pode ter alguns ganhos no uso de outras tecnologias, mas ao mesmo tempo que você ganha em algumas etapas agora, pode perder lá na frente.

A impressão 3D é mais do que uma revolução técnica, é uma revolução social. O dia que você tiver uma impressora 3D e puder fazer um sapato, como uma bota, se a impressão 3D ficar tão forte, poderá fazer que o conceito de beleza mude. Não sei se uma impressora 3D é capaz de fazer uma bota daquela, se não for, o que ela fizer se torne mais bonito e vire "o belo".

A revolução seria social, como seria fazer o sapato em casa, ou se vai ter lei para proteger? Ou se só imprime o sapato quem for um sapateiro? É uma loucura. Como por exemplo: você não irá mais numa Zara, não vai importar da China, da Espanha e enviar no container e colocar no Brasil.

"Se o cara comprar uma impressora 3D, falando bem como observador bem raso, se a impressora 3D for capaz de fazer tanta coisa como estava falando. A impressora vai ser específica, impressora de sapato é aquela. Você vai lá numa loja, vai ter vai no Studio, um designer vai fazer o meu sapato, faz um projeto e ele imprime seu sapato. Você paga seu sapato e sai com seu sapato. A revolução social é tão grande, mas assim, está aí, ela está vindo, mas não vi nenhum produto preocupante. Mas, mesmo assim, é uma coisa que vai mexer com o mundo da moda, 3D, fala tanto, coisa que a gente fala e nada acontece

Teria uma sugestão do que poderia ser feito na melhoria da sustentabilidade ambiental do setor calçadista brasileiro? Tem um vídeo de um movimento na Europa, que começou com Vinylplus, em 2010. A cadeia de pvc se organizou e colocou metas. Elas foram atingidas em 2010 e, depois, conseguiu-se fazer o Vinylplus.

Em 2017, foram reciclados 800.000 ton de PVC na Europa, em cima de um trabalho. E um dos targets foram as emissões. Se o pvc for queimado de qualquer jeito pode gerar dioxina, que não é bom. E qual o segredo? É queimar o pvc de forma certa, com incineradores adequados com fluxo de queima controlado, a emissão filtrada e controlada. Esse foi um trabalho pesado que a vinylplus fez porque boa parte da reciclagem lá é térmica, eles queimam para gerar energia. Então, agora o trabalho é diminuir a reciclagem enérgica e aumentar a reciclagem mecânica, na Europa que está 40-60\% a mais.

Há a dependência da cadeia, é necessário organizar, como foi com a Vinylplus. Só se consegue resultado organizando, um ajudando o outro, assim, só terei uma matéria prima sustentável se meu fornecedor trabalhar nisso. Uma coisa que interessa tanto, é a pesquisa (da outra professora) em incluir resíduos juntamente com polímeros virgens. 


\section{APÊNDICE F - Resultado Entrevista Empresa F}

\section{Pesquisa de campo (telefone) feita com a empresa calçadista - 10/12/2019 \\ PERFIS - EMPRESA F}

Perfil da entrevistada: função: Gestora Ambiental, Mais 20 anos de experiência no cargo atual.

Caracterização da instituição:

Nome: Empresa de grande porte

Fundação: década de 1950, Vale dos Sinos-RS

Porte: Grande porte

Tipo: particular

Número de colaboradores: 3.000 funcionários

Produção (em volume) 750.000 pares/mês

Público: calçados femininos

Missão: Ser uma empresa inovadora, que produza qualidade, moda e conforto, tornando-se essencial para os clientes, desejada pelas consumidoras e admirada por seus colaboradores e pelas comunidades onde atua (Seminário Integração e Inovação na Cadeia Produtiva do Calçado).

Valores: Honestidade, Transparência, Organização, Segurança, Humildade, Inteligência, Alegria e Compreensão (Seminário Integração e Inovação na Cadeia Produtiva do Calçado).

Tipo de processo produtivo: costura. Etapas e maquinários utilizados no processo produtivo: setor de corte (máquina de corte programada - desse 2014-15), costura (máquinas de costura), montagem (máquinas de conformar, máquinas de montagem) e expedição. Tipos de materiais utilizados: sintéticos, cabedais em diversos modelos, forros, sola, palmilha, salto, enfeites.

\section{PRIMEIRA PARTE - SELO ORIGEM SUSTENTÁVEL}

Primeiro contato da empresa sobre a Sustentabilidade: A companhia sempre adotou práticas sustentáveis, porém, nos últimos anos, a preocupação com questões relacionadas ao tema começou a ser maior principalmente para reforçar a identidade da empresa (Informe publicitário). Um marco importante foi quando a empresa deixou de utilizar couro bovino (1996) em seu produto e passou a utilizar o laminado sintético, mas foi um processo gradativo com ganhos positivos.

Participação do selo "Origem Sustentável": desde o início da criação do selo em 2013, a empresa foi uma das primeiras empresas a participar, mas tinha a estrutura diferente que é hoje. A partir da adesão ao programa, após o preenchimento de um questionário, já ganhava o selo branco, mas para atingir o selo bronze, era necessário comprovar por meio de documentos o que havia declarado no questionário e ainda passava por uma auditoria.

Nova versão (2019) do Programa "Origem Sustentável": Como a empresa já estava em processo de recertificar no método antigo e já atingia mais pontos do que estava sendo solicitado, então, já conseguiu certificar no novo sistema.

O que motivou para implantação: a empresa realiza um trabalho elaborado na busca da abertura de novos mercados, principalmente no campo da exportação. O comprador do exterior exige muito das empresas brasileiras que garanta uma documentação do produto, que informe a recomendação de uso, relatório de sustentabilidade e análises de laudos de matéria prima.

$\mathrm{Na}$ exportação, o controle da origem na captação da matéria prima é muito rigoroso, a empresa precisa informar qual é a responsabilidade ambiental e a questão sustentável do produto que ela está oferecendo no mercado. "A empresa que construiu aquele calçado, o que ela está preocupada? Qual são os trabalhos sociais, como é que ela trata os colaboradores, então já faz alguns anos que a empresa é também certificada pelo selo da Abvtex". 
O selo influenciou à relação da empresa com os fornecedores? Eles tiveram que se readequar de alguma maneira? Sim, o fornecedor precisou responder um formato de questionário, reportando ali algumas informações. Hoje, quando há a contratação de novas empresas, qualquer um terceiro ou parceiro, o setor jurídico já faz uma avaliação e verifica a situação de contratação por aquela empresa.

No início, teve uma certa dificuldade com os fornecedores, pois eles reportavam a questão da dificuldade com o custo dos testes dos materiais em relação ao produto exportação que precisava dos laudos de acordo com as normas interacionais.

Dentre uma das ações que a empresa vai realizar neste ano (2020) em realizar o primeiro encontro com os nossos fornecedores para mostrar e divulgar nossa política. Assim, trabalhar com os stakeholders sobre toda a cadeia, interna e externa, com a justificativa de melhor divulgar junto aos colaboradores e mostrar a melhoria contínua dentro dos setores.

Dentre as dimensões do selo em: econômico, ambiental, social e cultural. Entre eles, tem algum que seja mais importante para a empresa e por quê? Ou teve algum que não era tão evidenciado antes do selo? Todas as dimensões são de extrema relevância para empresa, com a restruturação do programa Origem a empresa tem o desafio de atender todas as dimensões no mesmo nível.

Para adquirir o selo, quais foram as principais mudanças internas para ajustar aos critérios do selo? Nessa segunda fase do selo, houve uma reestruturação do grupo, atualmente uma das diretoras da empresa e o gerente administrativo são norteadores do comitê de sustentabilidade.

O Comitê de Sustentabilidade recebeu inicialmente um treinamento sobre a nova metodologia do Programa Origem Sustentável, logo depois foram realizados debates entre o grupo e houve também a participação de alguns treinamentos promovidos pela Assintecal.

Contamos também com a parceria da empresa de consultoria, a qual presta assessoria ambiental e tem o viés voltado para o segmento, com um vasto conhecimento no quesito de sustentabilidade.

Iniciou-se workshops internos com os gestores de cada área e está sendo definida pelos diretores e pelo comitê a Política de Sustentabilidade da empresa, a qual vai nortear o programa de sustentabilidade da empresa.

Com a integração do Comitê de Sustentabilidade surgiram muitos assuntos importantes para serem incluídos no o projeto da empresa e, muitos já foram encaminhados para autorização da diretoria. Outra ação interna do grupo está sendo construída a partir da capacitação da equipe ao ver exemplos externos de como o mercado emprega à sustentabilidade. Assim, buscando informações de outras empresas que já atuam na sustentabilidade há mais de décadas, tanto fora do Brasil, quanto dentro, como em montadoras, contribuem para exemplificar e mostrar como o mercado vem acompanhando o tema.

Em relação aos benefícios que o resultado do processo de certificação já trouxe para a empresa, poderia dar alguns exemplos?

A inserção do valor "sustentabilidade" na cultura da organização permite que as decisões sejam tomadas não só pensando no lucro a curto prazo, mas também nos resultados a longo prazo, garantindo a perenidade da empresa (Informe publicitário).

Através de uma operação sustentável é possível fazer economias em matérias-primas, insumos e destinação final dos resíduos, gerando resultados financeiros para empresa (Informe publicitário)

Exemplo: A empresa começou a trabalhar soluções com os fornecedores, em relação à matéria prima, sobre o que poderia ser feito com o material excedente para reaproveitá-los dentro da cadeia. Com a parceria de um fornecedor foi quantificada as aparas de sintético e foram feitos testes para reinserir no processo produtivo. Isto gerou um resultado, que custeou os valores investidos e representa atualmente uma redução entre 20/25\% desses resíduos.

Há também a questão da meta do próximo ano (2020) na definição Política da Empresa. E isso impactará nas próximas etapa do projeto, assim, a equipe de Sustentabilidade também passará a auditar a empresa, pois essa reestruturação do programa necessita desse procedimento, inclusive também auditar externamente os fornecedores. 
Além disso, outro benefício que o Programa Origem Sustentável trouxe para a empresa são os conceitos das certificações "ISO".

\section{E das dificuldades, você poderia citar mais algum exemplo?}

As dificuldades maiores foram questões relacionadas as matérias-primas, os produtos variam na agregação de valor em relação à sustentabilidade, alguns fornecedores estão mais avançados nesse quesito, atingindo metas semelhantes ao programa (Origem Sustentável), porém as matérias primas mais alinhadas à sustentabilidade afetavam mais à parte econômica e atinge a competitividade entre eles.

\section{SEGUNDA PARTE - SUSTENTABILIDADE NO PRODUTO}

Sustentabilidade ambiental tem afetado o desenvolvimento de produto? Por exemplo, a questão das fontes naturais e biodegradáveis, isso tem afetado a empresa?

Entrevistada não tem informação sobre outros setores da empresa

O eco-design também tem sido uma forma de nascer um produto reduzindo o impacto ambiental. Normalmente relaciona-se quando diminui etapas produtivas, faz economia de energia, ou utilizar novas tecnologias (impressão 3D). Tem alguma ação nesse sentido na empresa?

Entrevistada não tem informação sobre outros setores da empresa

Outro caminho para a sustentabilidade ambiental é gestão do destino final. Existem ações na empresa? Há 4 tipos principais: reuso, reciclagem, geração de energia e descarte. Poderia apontar se a empresa aplica algum desses 4 tipos?

Sim. A empresa acredita que é possível produzir sem poluir, por isso destina os seus resíduos para locais licenciados e trabalha arduamente para reduzir dos resíduos gerados na produção dos seus calçados.

Atualmente aplicamos as seguintes tecnologias para os resíduos gerados no processo produtivo, logística reversa, reutilização, reciclagem e o coprocessamento.

Cerca de $75 \%$ dos resíduos gerados pela nossa empresa são encaminhados para o Coprocessamento, resíduos não passíveis de ser reciclados são destinados para coprocessamento em fornos de clínquer. Como funciona: os resíduos da indústria são misturados com resíduos de outros geradores, inclusive de setores distintos do calçado, com o intuito de formar uma mistura que apresente alto poder calorífico, sendo utilizada como combustível nas caldeiras para fabricação do clínquer, principal matéria-prima do cimento. As cinzas resultantes do processo podem ser incorporadas ao produto (clínquer), de forma a não restar passivo ambiental algum. O coprocessamento é realizado em plantas industriais com alto nível tecnológico de tratamento e monitoramento de emissões atmosféricas, sendo todo o processo certificado e licenciamento pelos órgãos ambientais competentes.

Há o interesse em trabalhar com a pirólise, que é um método antigo, só que o custo também é muito alto e há falta de indústrias que fazem esse processamento, que transformam o resíduo em matérias primas de origem.

E no calçado, sobre ações existentes no após o uso. Tem alguma ação por parte da empresa? Ou conhece alguma ação no Brasil?

Inexistem no País atualmente leis, regulamentos, normas administrativas ou acordos setoriais impondo a logística reversa dos calçados após o uso pelo consumidor. No momento, o tema não é considerado material para a companhia e seus stakeholders, estando o foco noutros impactos considerados de maior relevância. O calçado é um bem durável, que pode ser usado durante muitos anos, seja pelo consumidor que fez a aquisição ou terceiros que receberam o bem em doação. Temos conhecimento de empresas que instalaram PEVs - Pontos de Entrega Voluntária dos calçados após o uso em suas lojas, inclusive oferecendo descontos em novos produtos para o caso da entrega do calçado usado, porém, a adesão dos consumidores foi extremamente baixa, a ponto do projeto ser suspenso. Acreditamos que a médio/longo prazo o tema será objeto de regulamentação pelo Poder Público, abrindo-se um espaço de debate das melhores soluções para o caso.

Na embalagem há a parceria com a startup "Eu Reciclo", que faz a logística reversa das embalagens.

Teria uma sugestão do que poderia ser feito na melhoria da sustentabilidade ambiental do setor calçadista brasileiro? 
O setor calçadista, a exemplo dos demais segmentos da economia, está passando por um processo natural de transformação da cultura empresarial tradicional para a baseada na sustentabilidade. Este processo se dá em virtude das novas demandas dos consumidores e da sociedade de um modo geral, e as companhias que lutarem contra isso correm o risco de não ter sustentabilidade econômica no médio / longo prazo, vindo a perecer. Nossa sugestão do que pode ser feito na melhoria da sustentabilidade ambiental do setor calçadista brasileiro é a catalisação deste processo, por meio da estruturação e fortalecimento da estrutura de gestão da sustentabilidade dentro das empresas. Em vez de reagir às demandas de sustentabilidade e realizar ações esparsas, um sistema de gestão estratégica da sustentabilidade pode acelerar o processo de consolidação da nova cultura sustentável dentro da companhia, fazendo com que novos programas e projetos sejam criados e executados, e que a sustentabilidade seja um diferencial competitivo. Mais do que um projeto ou ação isolada, a sugestão é a de estruturar a sustentabilidade na organização, para que diversos projetos e ideias sejam continuamente gerados a partir disso. 
APÊNDICE G - Empresas do Inspiramais com ações sustentáveis

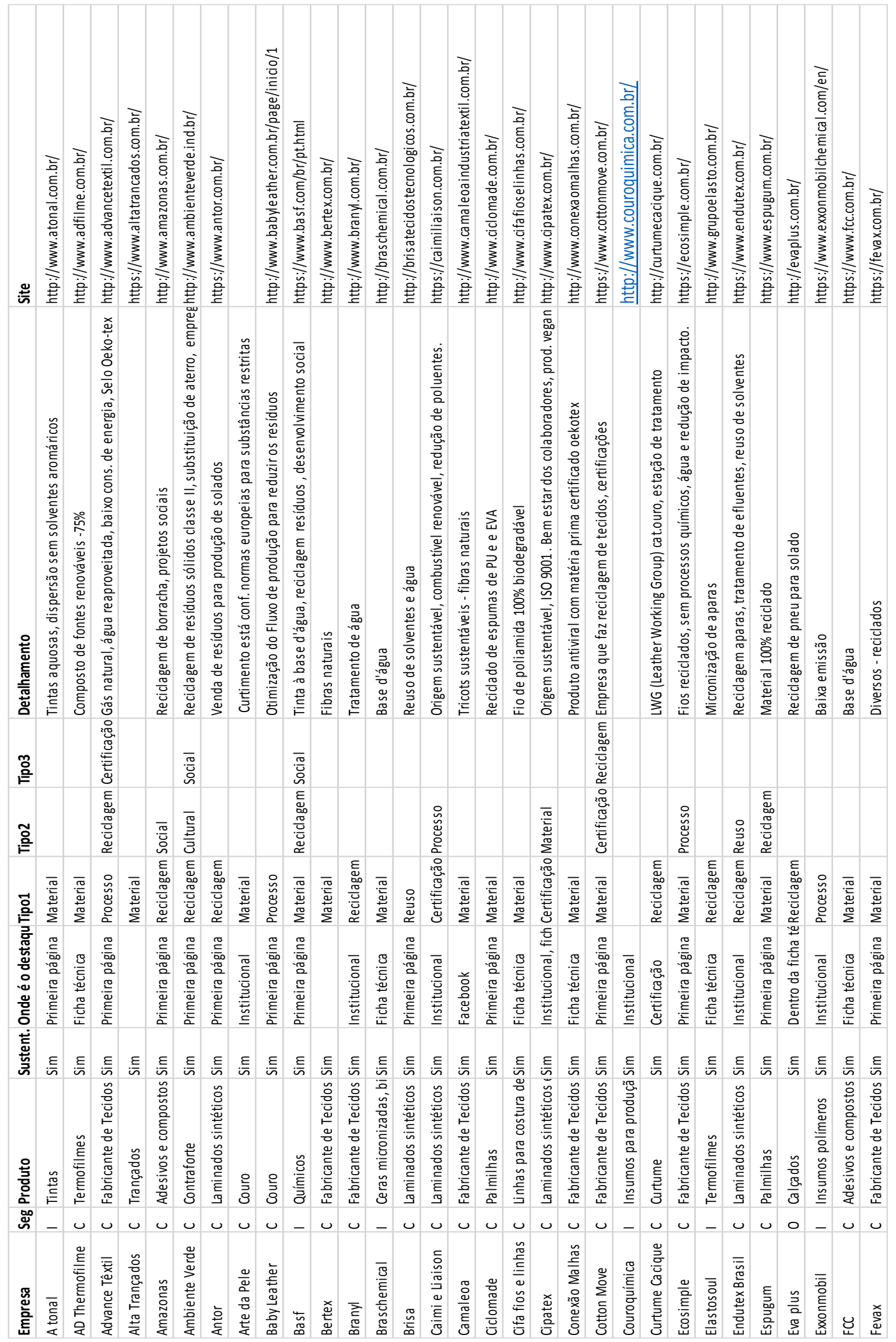




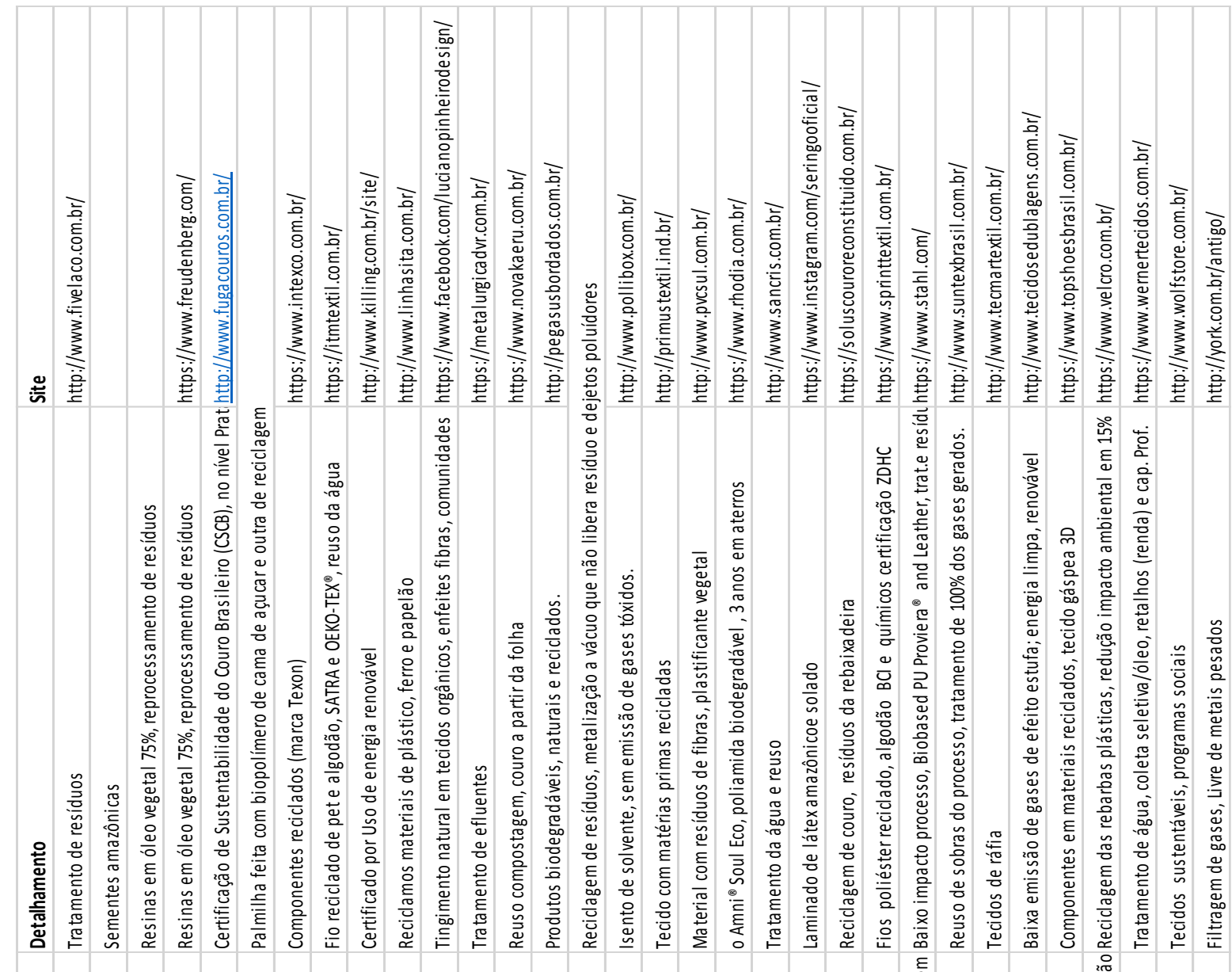

哭

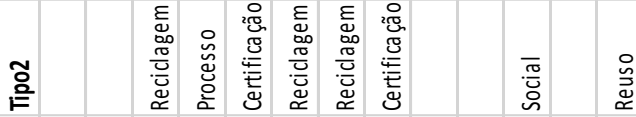

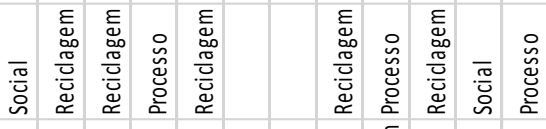

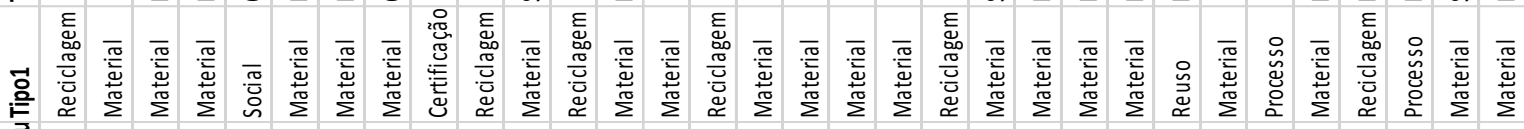

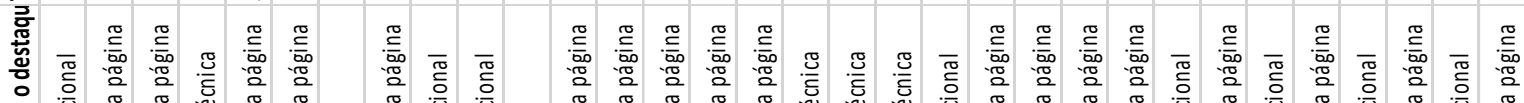

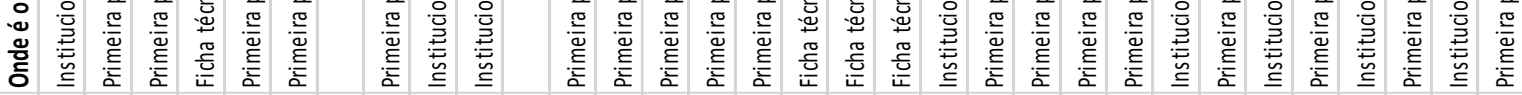

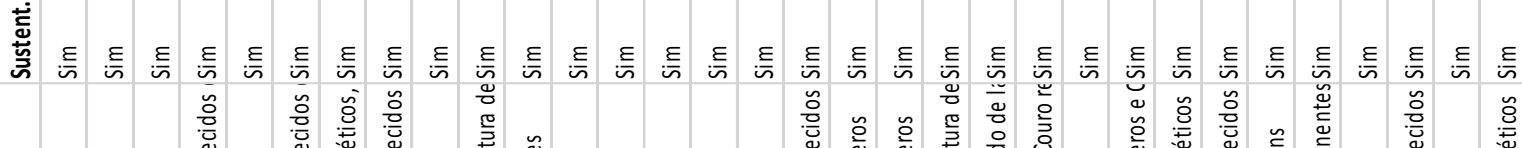

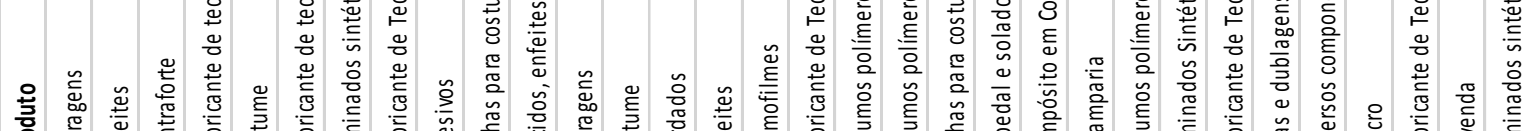

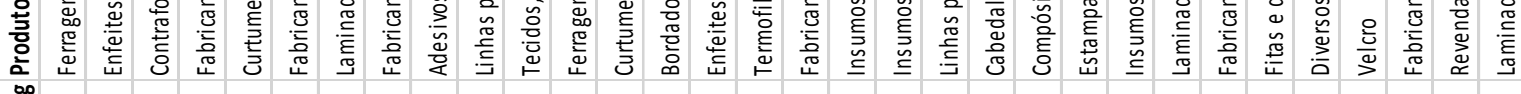

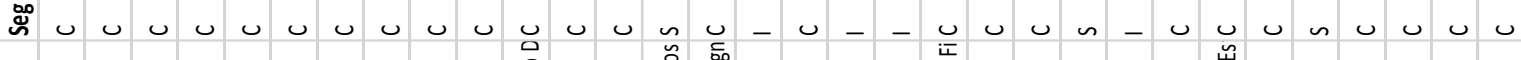

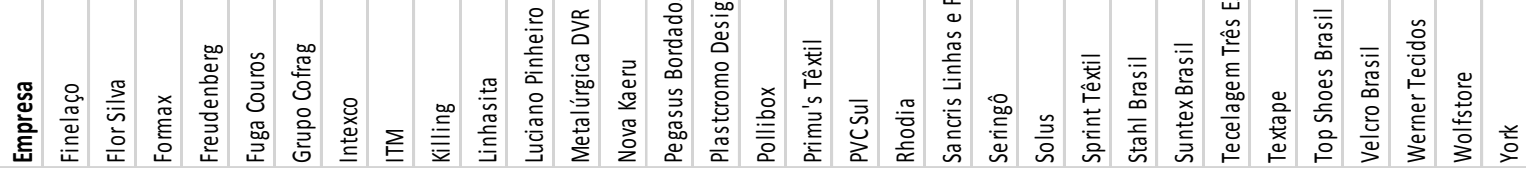




\section{APÊNDICE H - Imagens do MEV}

MEV-P2 (3\% serragem de bambu sem tratamento, 230x), P3 (6\% serragem de bambu sem tratamento, 190x), M2 (3\% serragem de bambu merceirizado, 200x), M3 (6\% serragem de bambu merceirizado, 230x), S2 (3\% serragem de bambu com tratamento de silano, 190x), S3 (6\% serragem de bambu com tratamento de silano, 150x).

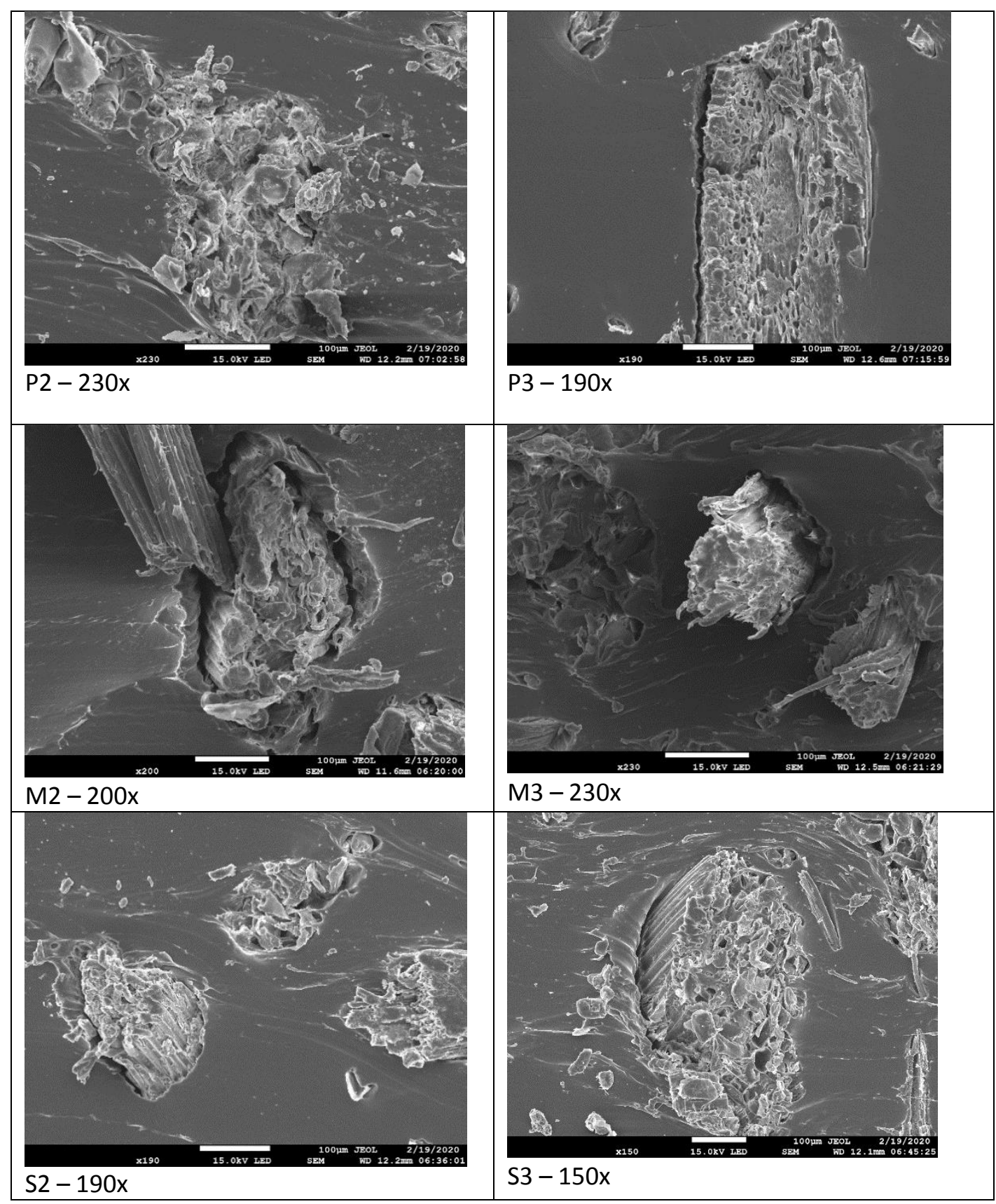

Fonte: (desenvolvido pelo autor) 
APÊNDICE I - Dados resultantes dos testes de dinamômetro

\begin{tabular}{|c|c|c|c|c|c|c|c|}
\hline & & $\begin{array}{l}\text { Carga } \\
\text { Máxima } \\
\text { (N) }\end{array}$ & $\begin{array}{c}\text { Carga } \\
\text { na } \\
\text { Quebra } \\
\text { (Padrão) } \\
\text { (N) }\end{array}$ & $\begin{array}{c}\text { Resistência } \\
\text { à Tração } \\
\text { na Carga } \\
\text { Máxima } \\
\text { (MPa) }\end{array}$ & $\begin{array}{c}\text { Alongamento } \\
\text { (Padrão) } \\
(\%)\end{array}$ & $\begin{array}{l}\text { Alongamento } \\
\text { na Quebra } \\
\text { (Padrão) } \\
(\mathrm{mm})\end{array}$ & $\begin{array}{c}\text { Módulo de } \\
\text { Young } \\
\text { (Automático) } \\
\text { (MPa) }\end{array}$ \\
\hline \multirow[t]{2}{*}{ PVC PURO } & Média & 148,63 & 147,22 & 7,04 & 396,39 & 85,79 & 3,59 \\
\hline & Dv. Pad. & 5,81 & 8,24 & 2,21 & 30,22 & 5,99 & 1,72 \\
\hline \multirow[t]{2}{*}{ 1,5\% PURO } & Média & 110,08 & 93,67 & 4,79 & 284,23 & 61,01 & 3,73 \\
\hline & Dv. Pad. & 5,75 & 8,97 & 0,64 & 31,53 & 5,76 & 0,50 \\
\hline \multirow[t]{2}{*}{$1,5 \% \mathrm{NaOH}$} & Média & 99,90 & 86,97 & 5,21 & 284,21 & 61,59 & 3,87 \\
\hline & Dv. Pad. & 4,46 & 7,06 & 0,60 & 13,66 & 3,94 & 0,37 \\
\hline \multirow[t]{2}{*}{$1,5 \%$ SILANO } & Média & 112,74 & 96,24 & 5,41 & 305,79 & 67,72 & 4,04 \\
\hline & Dv. Pad. & 4,56 & 6,41 & 0,59 & 16,79 & 2,74 & 0,27 \\
\hline \multirow[t]{2}{*}{$3,0 \%$ PURO } & Média & 98,89 & 84,54 & 4,60 & 259,73 & 56,26 & 4,07 \\
\hline & Dv. Pad. & 3,93 & 4,24 & 0,29 & 18,55 & 4,00 & 0,22 \\
\hline \multirow[t]{2}{*}{$3,0 \% \mathrm{NaOH}$} & Média & 98,02 & 84,06 & 4,65 & 279,88 & 62,02 & 3,76 \\
\hline & Dv. Pad. & 2,15 & 5,67 & 0,15 & 13,57 & 2,66 & 0,20 \\
\hline \multirow[t]{2}{*}{$3,0 \%$ SILANO } & Média & 98,16 & 84,95 & 4,41 & 251,20 & 56,82 & 3,91 \\
\hline & Dv. Pad. & 7,99 & 7,75 & 0,28 & 17,63 & 2,80 & 0,13 \\
\hline \multirow[t]{2}{*}{$6,0 \%$ PURO } & Média & 89,78 & 74,50 & 4,03 & 231,76 & 50,85 & 4,31 \\
\hline & Dv. Pad. & 3,33 & 6,20 & 0,26 & 31,09 & 5,86 & 0,44 \\
\hline \multirow[t]{2}{*}{$6,0 \% \mathrm{NaOH}$} & Média & 78,63 & 65,36 & 3,88 & 233,76 & 51,74 & 4,13 \\
\hline & Dv. Pad. & 4,74 & 4,11 & 0,51 & 14,40 & 2,41 & 0,49 \\
\hline \multirow[t]{2}{*}{$6,0 \%$ SILANO } & Média & 81,80 & 66,05 & 4,06 & 220,27 & 49,57 & 4,98 \\
\hline & Dv. Pad. & 3,49 & 7,06 & 0,44 & 24,19 & 6,15 & 0,39 \\
\hline
\end{tabular}




\section{ANEXOS}

\section{ANEXO A - Lista de Classificação Fiscal de Mercadorias - Tabela de NCM (Nomenclatura Comum do Mercosul)}

\section{Capítulo 64 - Calçado, polainas e artigos semelhantes; suas partes}

Notas.

1.- O presente Capítulo não compreende:

a) Os artigos descartáveis destinados a cobrir os pés ou o calçado, feitos de materiais frágeis ou pouco resistentes (por exemplo, papel, folhas de plástico) e sem solas aplicadas (regime da matéria constitutiva);

b) O calçado de matérias têxteis, sem sola exterior colada, costurada (cosida) ou de outro modo fixada ou aplicada à parte superior (Seção XI);

c) O calçado usado da posição 63.09;

d) Os artigos de amianto (posição 68.12);

e) O calçado e aparelhos ortopédicos, e suas partes (posição 90.21);

f) O calçado com características de brinquedo e o calçado fixado em patins (para gelo ou de rodas); caneleiras e outros artigos de proteção utilizados na prática de esportes (Capítulo 95).

2.- Não se consideram "partes", na acepção da posição 64.06, as cavilhas, protetores, ilhoses, colchetes, fivelas, galões, pompons, cordões para calçado e outros artigos de ornamentação ou de passamanaria, os quais seguem o seu próprio regime, nem os botões para calçado (posição 96.06).

3.- Na acepção do presente Capítulo:

a) Os termos "borracha" e "plástico" compreendem os tecidos e outros suportes têxteis que apresentem uma camada exterior de borracha ou de plástico perceptível à vista desarmada; para aplicação desta disposição, não se deve tomar em consideração as mudanças de cor provocadas pelas operações de obtenção desta camada exterior;

b) A expressão "couro natural" refere-se aos produtos das posições 41.07 e 41.12 a 41.14 .

4.- Ressalvado o disposto na Nota 3 do presente Capítulo:

a) A matéria da parte superior do calçado é determinada pela que constitua a maior superfície do revestimento exterior, considerando-se irrelevantes os acessórios ou reforços, tais como orlas, protetores de tornozelos, adornos, fivelas, presilhas, ilhoses ou dispositivos semelhantes; b) A matéria constitutiva da sola exterior é determinada pela que tenha a maior superfície de contato com o solo, considerando-se irrelevantes os acessórios ou reforços tais como pontas, barras, pregos, protetores ou dispositivos semelhantes.

Nota de subposições.

1.- Na acepção das subposições 6402.12, 6402.19, 6403.12, 6403.19 e 6404.11 considera-se "calçado para esporte", exclusivamente:

a) O calçado concebido para a prática de uma atividade esportiva, munido de ou preparado para receber pontas, grampos (crampons), cravos, barras ou dispositivos semelhantes;

b) O calçado para patinagem, esqui, surfe de neve, luta, boxe e ciclismo. 


\begin{tabular}{|c|c|}
\hline NCM & DESCRIÇÃO \\
\hline 64.01 & $\begin{array}{l}\text { Calçado impermeável de sola exterior e parte superior de borracha ou plástico, em } \\
\text { que a parte superior não tenha sido reunida à sola exterior por costura ou por meio } \\
\text { de rebites, pregos, parafusos, espigões ou dispositivos semelhantes, nem formada por } \\
\text { diferentes partes reunidas pelos mesmos processos. }\end{array}$ \\
\hline 6401.10 .00 & - Calçado com biqueira protetora de metal \\
\hline 6401.9 & - Outro calçado: \\
\hline 6401.92 .00 & -- Cobrindo o tornozelo, mas não o joelho \\
\hline 6401.99 & -- Outro \\
\hline 6401.99 .10 & Cobrindo o joelho \\
\hline 6401.99 .90 & Outro \\
\hline 64.02 & Outro calçado com sola exterior e parte superior de borracha ou plástico. \\
\hline 6402.1 & - Calçado para esporte: \\
\hline 6402.12 .00 & -- Calçado para esqui e para surfe de neve \\
\hline 6402.19 .00 & -- Outro \\
\hline 6402.20 .00 & $\begin{array}{l}\text { - Calçado com parte superior em tiras ou correias, fixados à sola por } \\
\text { pregos, tachas, pinos e semelhantes }\end{array}$ \\
\hline 6402.9 & - Outro calçado: \\
\hline 6402.91 & -- Cobrindo o tornozelo \\
\hline 6402.91 .10 & Com biqueira protetora de metal \\
\hline 6402.91 .90 & Outro \\
\hline 6402.99 & -- Outro \\
\hline 6402.99 .10 & Com biqueira protetora de metal \\
\hline 6402.99 .90 & Outro \\
\hline 64.03 & $\begin{array}{l}\text { Calçado com sola exterior de borracha, plástico, couro natural ou reconstituído e } \\
\text { parte superior de couro natural. }\end{array}$ \\
\hline 6403.1 & - Calçado para esporte: \\
\hline 6403.12 .00 & -- Calçado para esqui e para surfe de neve \\
\hline 6403.19 .00 & -- Outro \\
\hline 6403.20 .00 & $\begin{array}{l}\text { - Calçado com sola exterior de couro natural e parte superior constituída por } \\
\text { tiras de couro natural passando pelo peito do pé e envolvendo o dedo grande }\end{array}$ \\
\hline 6403.40 .00 & - Outro calçado, com biqueira protetora de metal \\
\hline 6403.5 & - Outro calçado, com sola exterior de couro natural: \\
\hline 6403.51 & -- Cobrindo o tornozelo \\
\hline 6403.51 .10 & Com sola de madeira e desprovido de palmilha \\
\hline 6403.51 .90 & Outro \\
\hline 6403.59 & -- Outro \\
\hline 6403.59 .10 & Com sola de madeira e desprovido de palmilha \\
\hline 6403.59 .90 & Outro \\
\hline
\end{tabular}




\begin{tabular}{|c|c|}
\hline 6403.9 & - Outro calçado: \\
\hline 6403.91 & -- Cobrindo o tornozelo \\
\hline 6403.91 .10 & Com sola de madeira e desprovido de palmilha \\
\hline 6403.91 .90 & Outro \\
\hline 6403.99 & -- Outro \\
\hline 6403.99 .10 & Com sola de madeira e desprovido de palmilha \\
\hline 6403.99 .90 & Outro \\
\hline 64.04 & $\begin{array}{l}\text { Calçado com sola exterior de borracha, plástico, couro natural ou reconstituído e } \\
\text { parte superior de matérias têxteis. }\end{array}$ \\
\hline 6404.1 & - Calçado com sola exterior de borracha ou de plástico: \\
\hline 6404.11 .00 & -- Calçado para esporte; calçado para tênis, basquetebol, ginástica, treino e semelhantes \\
\hline 6404.19 .00 & -- Outro \\
\hline 6404.20 .00 & - Calçado com sola exterior de couro natural ou reconstituído \\
\hline 64.05 & Outro calçado. \\
\hline 6405.10 & - Com parte superior de couro natural ou reconstituído \\
\hline 6405.10 .10 & Com sola exterior de borracha ou plástico e parte superior de couro reconstituído \\
\hline 6405.10 .20 & $\begin{array}{l}\text { Com sola exterior de couro natural ou reconstituído e parte superior de couro } \\
\text { reconstituído }\end{array}$ \\
\hline 6405.10 .90 & Outro \\
\hline 6405.20 .00 & - Com parte superior de matérias têxteis \\
\hline 6405.90 .00 & - Outro \\
\hline 64.06 & $\begin{array}{l}\text { Partes de calçado (incluindo as partes superiores, mesmo fixadas a solas que não } \\
\text { sejam as solas exteriores); palmilhas, reforços interiores e artigos semelhantes, } \\
\text { amovíveis; polainas, perneiras e artigos semelhantes, e suas partes. }\end{array}$ \\
\hline 6406.10 .00 & - Partes superiores de calçado e seus componentes, exceto contrafortes e biqueiras rígidas \\
\hline 6406.20 .00 & - Solas exteriores e saltos, de borracha ou plástico \\
\hline 6406.90 & - Outros \\
\hline 6406.90 .10 & Solas exteriores e saltos, de couro natural ou reconstituído \\
\hline 6406.90 .20 & Palmilhas \\
\hline 6406.90 .90 & Outros \\
\hline
\end{tabular}

Fonte: (BRASIL, [s.d.]) 
ANEXO B - Princípios, Critérios e quantidade de Indicadores do Selo Origem Sustentável

\begin{tabular}{|c|c|c|}
\hline \multicolumn{3}{|c|}{ Gestão da Sustentabilidade } \\
\hline PRINCÍPIOS & CRITÉRIOS & INDICADORES \\
\hline \multirow{4}{*}{$\begin{array}{l}\text { Princípio I - Sistema de } \\
\text { Gestão }\end{array}$} & Critério I -Política de Sustentabilidade & 2 \\
\hline & Critério II - Informação documentada & 4 \\
\hline & Critério III - Liderança e comprometimento & 2 \\
\hline & $\begin{array}{l}\text { Critério IV - Monitoramento, medição, análise de } \\
\text { melhoria }\end{array}$ & 3 \\
\hline \multicolumn{3}{|c|}{ Dimensão Econômica } \\
\hline PRINCÍPIOS & CRITÉRIOS & INDICADORES \\
\hline \multirow{3}{*}{$\begin{array}{l}\text { Princípio I - } \\
\text { Desempenho da } \\
\text { produção }\end{array}$} & Critério I - Produtividade & 2 \\
\hline & Critério II - Controle Operacional & 5 \\
\hline & Critério III - Desempenho operacional dos funcionários & 3 \\
\hline \multirow{2}{*}{$\begin{array}{l}\text { Princípio II - } \\
\text { Desempenho do } \\
\text { produto }\end{array}$} & Critério I - Controle da qualidade & 6 \\
\hline & Critério II - Pesquisa e desenvolvimento & 4 \\
\hline \multirow{2}{*}{$\begin{array}{l}\text { Princípio III - Impactos } \\
\text { econômicos }\end{array}$} & Critério I - Desempenho do Processo & 1 \\
\hline & Critério II - Resultado econômico & 2 \\
\hline \multicolumn{3}{|c|}{ Dimensão Ambiental } \\
\hline PRINCÍPIOS & CRITÉRIOS & INDICADORES \\
\hline \multirow{2}{*}{$\begin{array}{l}\text { Princípio I - } \\
\text { Cumprimento dos } \\
\text { requisitos legais } \\
\text { aplicáveis }\end{array}$} & Critério I - Requisitos legais para a organização & 3 \\
\hline & Critério II - Requisitos legais para subcontratações & 1 \\
\hline $\begin{array}{l}\text { Princípio II - } \\
\text { Rastreabilidade }\end{array}$ & Critério I - Origem das matérias primas & 1 \\
\hline \multirow{3}{*}{$\begin{array}{l}\text { Princípio III - Controle } \\
\text { de substâncias restritas }\end{array}$} & Critério I - Requisitos & 1 \\
\hline & Critério II - Ensaios & 3 \\
\hline & $\begin{array}{l}\text { Critério III - Monitoramento de substâncias restritas } \\
\text { nas matérias-primas }\end{array}$ & 3 \\
\hline \multirow{2}{*}{$\begin{array}{l}\text { Princípio IV - } \\
\text { Gerenciamento do uso } \\
\text { de água }\end{array}$} & Critério I - Consumo de água & 1 \\
\hline & $\begin{array}{l}\text { Critério II - Medidas de racionalização e redução do } \\
\text { uso de água }\end{array}$ & 2 \\
\hline \multirow{2}{*}{$\begin{array}{l}\text { Princípio V - } \\
\text { Gerenciamento do uso } \\
\text { de energia }\end{array}$} & Critério I - Consumo de energia & 1 \\
\hline & $\begin{array}{l}\text { Critério II - Medidas de racionalização e redução do } \\
\text { uso de energia }\end{array}$ & 2 \\
\hline \multirow{2}{*}{$\begin{array}{l}\text { Princípio VI - Redução } \\
\text { do impacto ambiental } \\
\text { do produto e do } \\
\text { processo produtivo }\end{array}$} & Critério I - Redução do impacto ambiental do produto & 1 \\
\hline & $\begin{array}{l}\text { Critério II - Redução do impacto ambiental do } \\
\text { processo produtivo }\end{array}$ & 1 \\
\hline \multirow{5}{*}{$\begin{array}{l}\text { Princípio VII - } \\
\text { Gerenciamento de } \\
\text { resíduos sólidos }\end{array}$} & Critério I - Diretrizes & 1 \\
\hline & Critério II - Geração e destinação & 2 \\
\hline & Critério III - Minimizar a geração & 1 \\
\hline & Critério IV - Armazenamento temporário & 1 \\
\hline & Critério V - Embalagens & 2 \\
\hline \multirow{2}{*}{$\begin{array}{l}\text { Princípio VIII - } \\
\text { Tratamento de } \\
\text { efluentes líquidos }\end{array}$} & Critério I - Sistema de tratamento & 3 \\
\hline & Critério II - Minimização de efluentes gerados & 2 \\
\hline \multirow{5}{*}{$\begin{array}{l}\text { Princípio IX - } \\
\text { Gerenciamento de } \\
\text { emissões atmosféricas }\end{array}$} & Critério I - Atendimento dos limites & 1 \\
\hline & Critério II - Inventário de emissões & 2 \\
\hline & $\begin{array}{l}\text { Critério III - Plano de manutenção e limpeza dos } \\
\text { equipamentos }\end{array}$ & 1 \\
\hline & Critério IV - Emissão de compostos orgânicos voláteis & 2 \\
\hline & Critério V - Ruído externo & 1 \\
\hline
\end{tabular}


Critério I - Requisitos legais para a organização

Critério II - Trabalho infantil, forçado ou semelhando

Princípio I ao trabalho escravo

Critério III - Trabalho infantil, forçado ou semelhando ao trabalho escravo na subcontratação

Critério IV - Saúde e Segurança

Critério V - Contratação de funcionários Critério VI - Regularidade fiscal

Critério I - Conscientização sobre a Saúde e Segurança

Ocupacional

Critério II - Preparação e resposta de emergência

Critério III - Armazenamento e manuseio de insumos

químicos

Princípio II - Público interno
Critério IV - Ambiente de Trabalho 3

Critério V - Liberdade de Expressão 2

Critério VI - Discriminação e preconceito 3

Critério VII - Desenvolvimento profissional 6

Critério VIII - Remuneração e benefícios 2

Critério IX - Conscientização sobre a responsabilidade 1 social

Critério I - Avaliação e seleção de fornecedores, contratos e terceirizados
Princípio III -

Fornecedores, contratados e terceirizados

\begin{tabular}{|c|c|c|}
\hline $\begin{array}{l}\text { Princípio IV - Relações } \\
\text { com a concorrência }\end{array}$ & Critério I - Concorrência leal & 1 \\
\hline \multirow{3}{*}{ Princípio V - Clientes } & Critério I - Canais de comunicação & 1 \\
\hline & Critério II - Relações comerciais & 5 \\
\hline & Critério I - Relação com a comunidade local & 2 \\
\hline \multirow{2}{*}{$\begin{array}{l}\text { Princípio VI - } \\
\text { Envolvimento com a } \\
\text { comunidade, governo e } \\
\text { sociedade }\end{array}$} & $\begin{array}{l}\text { Critério II - Envolvimento com o governo ou entidades } \\
\text { públicas }\end{array}$ & 1 \\
\hline & $\begin{array}{l}\text { Critério III - Canal de atendimento a reclamações e de } \\
\text { relações públicas }\end{array}$ & 1 \\
\hline \multicolumn{3}{|c|}{ Dimensão Cultural } \\
\hline PRINCÍPIOS & CRITÉRIOS & INDICADORES \\
\hline \multirow{5}{*}{$\begin{array}{l}\text { Princípio I - Valorização } \\
\text { da cultura interna }\end{array}$} & $\begin{array}{l}\text { Critério I - Salvaguarda da história, cultura e valores da } \\
\text { empresa }\end{array}$ & 1 \\
\hline & $\begin{array}{l}\text { Critério II - Engajamento em programas de } \\
\text { preservação da cultura empresarial }\end{array}$ & 1 \\
\hline & $\begin{array}{l}\text { Critério III - Promoção de ações de sustentabilidade } \\
\text { voltadas à cultura }\end{array}$ & 1 \\
\hline & $\begin{array}{l}\text { Critério IV - Divulgação e disseminação de ações } \\
\text { socioambiental }\end{array}$ & 1 \\
\hline & $\begin{array}{l}\text { Critério V- Modelo de negócio com foco em } \\
\text { sustentabilidade e valorização da cultura }\end{array}$ & 3 \\
\hline \multirow{2}{*}{$\begin{array}{l}\text { Princípio II - Valorização } \\
\text { da cultura junto aos } \\
\text { públicos de interesse }\end{array}$} & $\begin{array}{l}\text { Critério I - Sensibilização sobre princípios de } \\
\text { sustentabilidade e valorização da cultura }\end{array}$ & 1 \\
\hline & $\begin{array}{l}\text { Critério II -Salvaguarda da história, cultura e valores da } \\
\text { comunidade local, regional e nacional }\end{array}$ & 1 \\
\hline
\end{tabular}

Fonte: Adaptado (ORIGEM SUSTENTÁVEL, 2019) 
ANEXO C - Programação do evento "Sustentabilidade: é hora de avançar"

PROGRAMAÇÃO COMPLETA

18h - ABERTURA

18h15 - PALESTRA GREEN \& GOOD

Com Alexandre Birman (Arezzo \& Co)

$\mathbf{1 8 h 3 5}$ - CASE DE SUSTENTABILIDADE: LOJAS RENNER

Com Eduardo Möller Ferlauto (Lojas Renner)

19h20 - APRESENTAÇÃO DOS PROGRAMAS DE SUSTENTABILIDADE

19h50 - PAINEL COM CONVIDADOS

Eduardo Möller Ferlauto (Lojas Renner)

Ismael Fischer (Calçados Bibi)

Marcelo Nicolau (Cipatex)

Mauro Pedro Becker (Curtume Mats)

$20 \mathrm{~h} 30$ - ENCERRAMENTO

Fonte: (ASSINTECAL, 2019) 